$$
\text { UNIVERSIDADE DE SÃO PAULO }
$$

FACULDADE DE FILOSOFIA, LETRAS E CIÊNCIAS HUMANAS DEPARTAMENTO DE HISTÓRIA

PROGRAMA DE PÓS-GRADUAÇÃO EM HISTÓRIA ECONÔMICA

\title{
Setor externo e política econômica do Brasil, 1913-1918
}


Prof. Dr. Marco Antonio Zago

Reitor da Universidade de São Paulo

Prof. Dr. Sérgio França Adorno de Abreu

Diretor da Faculdade de Filosofia, Letras e Ciências Humanas

Osvaldo Luis Angel Coggeola

Chefe de Departamento da História

Profa. Dra. Sara Albieri

Coordenadora do Programa de Pós-Graduação em História Econômica 
JOIMAR DE CASTRO MENEZES

\section{Setor externo e política econômica do Brasil, 1913-1918}

Tese apresentada à Faculdade de Filosofia, Letras e Ciências Humanas da Universidade de São Paulo para obtenção do título de Doutor em Ciências

Área de concentração: História Econômica

Orientador: Prof. Dr. Renato Perim Colistete 
Nome: Joimar de Castro Menezes

Título: Setor externo e política econômica do Brasil, 1913-1918

Tese apresentada à Faculdade de Filosofia, Letras e Ciências Humanas da Universidade de São Paulo para obtenção do título de Doutor em Ciências

$\underline{\text { Banca Examinadora }}$ 


\section{RESUMO}

Joimar MENEZES. Setor externo e política econômica do Brasil (1913-1918) [tese]. Universidade de São Paulo, Faculdade de Filosofia, Letras e Ciências Humanas, São Paulo, 2015, f.

Esta tese analisa a relação entre o setor externo e as mudanças ocorridas na política econômica do Brasil entre a Crise de 1913 e o fim da Primeira Guerra Mundial. O objetivo principal é estabelecer relações entre a crise financeira que teve início quando as Guerras Balcânicas envolveram interesses dos principais países da Europa Ocidental. O receio de que os confrontos nos Bálcãs provocassem mudanças na geopolítica da região levou o mercado financeiro europeu a entesourar recursos. Este entesouramento dificultou o acesso de recursos em ouro pelo Brasil. A economia brasileira era dependente do setor externo. A falta de divisas levou à redução nas exportações dos principais produtos que o Brasil comercializava no mercado internacional: café e borracha. A retração nas vendas internacionais dificultou o financiamento das importações, que foram reduzidas em percentual acima do verificado com nas exportações. A solução foi solicitar uma nova consolidação da dívida externa brasileira que entrou para a história como o segundo funding loan. A Crise de 1913 previa os eventos que se consolidariam como a Primeira Guerra Mundial. O Brasil foi forçado a modificar a sua política econômica. Novos mecanismos de atuação da economia brasileira no cenário internacional foram experimentados. A economia brasileira chegou ao fim de 1918 com novas perspectivas de atuação na economia internacional.

Palavras-chave: setor externo, política econômica, Primeira Guerra Mundial, comércio exterior. 


\begin{abstract}
Joimar MENEZES. External sector and economic policy of Brazil (1913-1918) [thesis]. Universidade de São Paulo, Faculdade de Filosofia, Letras e Ciências Humanas, São Paulo, 2015, f.

This thesis analyzes the relationship between the external sector and the changes in economic policy in Brazil between 1913 crisis and the end of World War I. The main objective is to establish links between the financial crisis that began when the Balkan Wars involved interests of the major Western European countries. The fear that the clashes in the Balkans provoked changes in the geopolitics of the region led the European financial market to hoard resources. This hoarding hindered the access of gold resources in Brazil. The Brazilian economy was dependent on the external sector. The lack of foreign exchange led to a reduction in exports of the main products that Brazil traded in the international market: coffee and rubber. The decline in international sales hampered the financing of imports, which were reduced by a percentage higher than that observed with exports. The solution was to request further consolidation of Brazil's foreign debt went down in history as the second funding loan. The Crisis 1913 predicted the events that would consolidate as the First World War. Brazil was forced to change its economic policy. New mechanisms of action of the Brazilian economy in the international arena have been tried. The Brazilian economy has ended 1918 with new perspectives of action in the international economy.
\end{abstract}

Keywords: external sector, economic policy, World War I, foreign trade. 


\section{LISTA DE FIGURAS}

Figura 3.1 - Datas das declarações de guerra - fase inicial da Primeira Guerra Mundial, 1914-5..

Figura 5.1 - Destino das emissões de curso forçado realizadas entre 1914 e 1917 (contos de réis).

Figura 5.2 - Finalidade de títulos públicos emitidos entre janeiro de 1915 a março de 1917 (contos de réis)

Figura 5.3 - Proposta do Ministério da Fazenda para cobrir o déficit de 1917.151

Figura 7.1 - Quadro-resumo da dívida externa do estado de São Paulo (libras esterlinas) 15190

Figura 7.2 - Quadro-resumo dos assuntos pendentes entre os governos do Brasil e do Reino Unido.

Figura 8.1 - Relações diplomáticas entre países do Continente Americano e o Império Alemão. 213

Figura 10.1 - Statutory List Brasil, junho 1916. 269

Figura 11.1 - Empréstimos do Tesouro dos Estados Unidos para o Tesouro do Reino Unido, parciais 1917 e 1918 (US\$ mil)... 


\section{LISTA DE TABELAS}

Tabela 1.1 - Principais mercadorias exportadas, Brasil, 1871 - 1930 (\% sobre valor total

Tabela 1.2 - Principais destinos das exportações, Brasil, 1901-1914 (\% sobre valor total 31

Tabela 1.3 - Principais origens das importações, Brasil, 1901 - 1914 (\% sobrevalor total). .32

Tabela 1.4 - Balança Comercial, Brasil, 1911- 1915 (libra esterlina, mil) ...... 38

Tabela 1.5 - Balança Comercial, Brasil, 1901 - 1914 (libra esterlina, mil) .... 41

Tabela 1.6 - Principais produtos exportados, Brasil, 1912-3 (libra esterlina) 42

Tabela 1.7 - Intercâmbio comercial - Brasil e principais parceiros, 1909 -

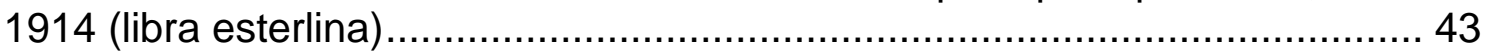

Tabela 1.8 - Exportações brasileiras de borracha, (libra esterlina, mil)......... 46

Tabela 2.1 - Receitas da União, orçamento e arrecadação, 1913-4 (contos de réis). 56

Tabela 2.2 - Variação (\%) no preço da saca de café (mil-réis) e na taxa de câmbio (libra esterlina), 1898/9 - 1904/5 .................................................. 71

Tabela 2.3 - M1 - papel moeda em poder do público - fim do período (conto de réis, mil)

Tabela 2.4 - Taxa cambial média para a sexta-feira de cada semana até o final de junho de 1914, após, diária (libra esterlina) ...................................... 76

Tabela 2.5 - Caixa de Conversão - total depósitos em ouro, 1909-1912 (libra esterlina)

Tabela 2.6 - Caixa de Conversão - total depósitos em ouro, 1913 (libra esterlina)

Tabela 3.1 - Receitas e despesas efetivas da União, 1913- 1919 (contos de réis).

Tabela 3.2 - Dívida externa do Brasil, 1889 - outubro 1913 (libras esterlinas).

Tabela 3.3 - Taxa cambial - média diária para a sexta-feira de cada semana até o final de junho de 1914 e diária a partir de então, até o final de 1914 (pence / Rs).... 
Tabela 4.1 - Receita da União, dos Estados e dos Municípios, 1913-1919 (contos de réis).

Tabela 4.2 - Receita da União, dos Estados e dos Municípios, 1913-1919 (contos de réis).

Tabela 4.3 - Brasil - Impostos de importação, 1913-1919 (contos de réis, ouro)

Tabela 4.4 - Impostos de importação orçados e arrecadados, Brasil, 19131919 (contos de réis)

Tabela 4.5 - Renda dos tributos orçados, Brasil, 1914 (contos de réis, ouro e papel)

Tabela 4.6 - Renda dos tributos orçados, Brasil, 1918 (contos, ouro e papel).

Tabela 4.7 - Renda dos tributos e imposto de consumo em relação ao orçamento, Brasil, 1913-1919 (contos de réis, ouro e papel)......

Tabela 4.8 - Renda com aplicação especial, valores orçados e arrecadados, Brasil, 1913-1919 (contos de réis, ouro e papel). 124

Tabela 4.9 - Imposto sobre a renda, valores orçados, Brasil, 1913-1919 (contos de réis).

Tabela 4.10- Imposto sobre o consumo, valores orçados, Brasil, 1914 (contos de réis).

Tabela 4.11- Imposto sobre o consumo, valores orçados, Brasil, 1918 (contos de réis).

Tabela 4.12- Impostos sobre o consumo, valores orçados e arrecadados, Brasil, 1913-1919 (contos de réis). 129

Tabela 4.13- Rendas industriais e valores orçados, Brasil, 1914 (contos de réis, ouro e papel).. 131

Tabela 4.14- Rendas Industriais, valores orçados, Brasil, 1918 (contos de réis, ouro e papel) 132

Tabela 4.15- Despesas Gerais, valores orçados, Brasil, 1914 (contos de réis, ouro e papel)

Tabela 4.16- Despesas Gerais, valores orçados, Brasil, 1918 (contos de réis, ouro e papel)

Tabela 4.17- Receitas e despesas efetivas da União, 1913- 1919 (contos de réis). 
Tabela 4.18- Despesa da União, dos Estados e dos Municípios, 1913-1919 (contos de réis).

Tabela 4.19- Discriminação da despesa da União, 1913-1919, segundo os diversos Ministérios (contos de réis em papel) - Fazenda (contos de réis em ouro)

Tabela 4.20 - Discriminação da despesa da União Federal realizada, 19131919, segundo os diversos ministérios (contos de réis).

Tabela 6.1 - Emissão de certificados-ouro e importações, 1909-1915 (libras esterlinas)

Tabela 6.2 - Taxa de câmbio média mensal da libra esterlina, 1915-1917, Rio de Janeiro (réis por pence)

Tabela 6.3 - Taxa cambial no Rio de Janeiro, 01 janeiro - 18 março 1915 (pence / mil-réis).

Tabela 7.1 - Brasil, exportação de café, 1910 - 1920 203

Tabela 10.1- Comércio Exterior do Brasil 1911-1919 (libra esterlina, mil) ... 273

Tabela 10.2- Valor da importação de equipamento industrial (libras esterlinas a preços de 1913) 275

Tabela 10.3- Exportações de borracha tipo Pará, 1913-7 (toneladas) 278

Tabela 10.4- Total de exportações do Brasil entre janeiro e setembro, comparação 1914 e 1917. 283

Tabela 10.5- Quantidade, valor total e valor médio saca de café $(60 \mathrm{~kg})$ exportado pelo Brasil, 1910 - 1920. 


\section{LISTA DE ABREVIATURAS E DE SIGLAS DE DOCUMENTOS}

BAS

Banco do Brasil

BDB

BI

BTB

HMG

MAF

NM

NMR

SBP

$\mathrm{T}$

TA

TE

WA

WTD
Brazilian Assistance Scheme

Banco do Brasil

British Delegation in Brazil

Banco da Inglaterra (Banco Central do Reino Unido)

British Trade Bank

His Majesty Government (Reino Unido)

Ministry of Agriculture and Food (Reino Unido)

Navio Mercante

Nathan Mayer Rothschild (casa bancária)

Schröder Bank PLC (casa bancária)

Treasury (Tesouro do Reino Unido)

Tríplice Aliança

Tríplice Entente

War Office (Reino Unido)

War Trade Department (Reino Unido) 


\section{SUMÁRIO}

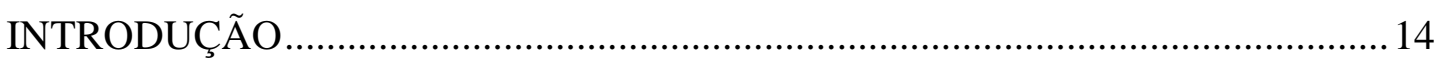

PARTE I - O cenário externo do Brasil antes da Primeira Guerra Mundial..............22

CAPÍTULO 1 - Impactos da crise internacional no financiamento externo brasileiro

1.1 As guerras nos Bálcãs e a crise internacional de 1913 .............................23

1.2 Aspectos do comércio exterior brasileiro................................................40

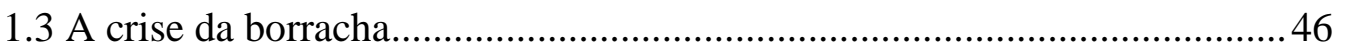

CAPÍTULO 2 - Impactos da crise internacional no financiamento interno brasileiro54

2.1 Aspectos gerais das importações...........................................................55

2.2 Câmbio e o fim da Caixa de Conversão...................................................... 66

PARTE II - A economia brasileira durante a guerra: o custo da neutralidade ..........89

CAPÍTULO 3 - A economia brasileira à espera dos recursos do funding loan ..........89

$3.1 \mathrm{O}$ processo de negociação do funding loan ..............................................90

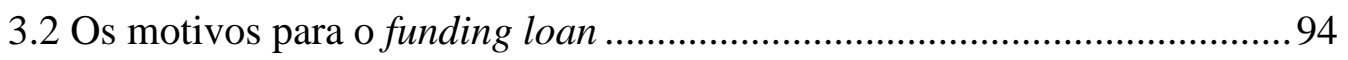

CAPÍTULO 4 - Orçamento público do Brasil em tempos de guerra.........................114

4.1 A dependência dos orçamentos do imposto de importação .....................114

4.2 As modificações que a guerra trouxe para a tributação ............................ 119

CAPÍTULO 5 - Ministério da Fazenda - período Pandiá Calógeras........................ 141

5.1 A administração do Ministério da Fazenda durante a guerra.................... 142

5.2 A gestão de Calógeras na Fazenda ......................................................... 145

CAPÍTULO 6-A atuação do Banco do Brasil no setor externo da economia brasileira 164

6.1 O processo de ascensão do Banco do Brasil no setor externo brasileiro .. 164

6.2 A especialização do Banco do Brasil em negócios internacionais ............169

CAPÍTULO 7 - Intermediação bancária internacional: Rothschild e Schröder .......183 
7.1 A dependência da economia brasileira das casas bancárias Rothschild e Schröder. .184

7.2 Diversificação de negócios financeiros 188

PARTE III - Negócios internacionais do Brasil durante a guerra 207

CAPÍTULO 8 - Relações econômicas do Brasil com o Império Alemão 207

8.1 As raízes das relações econômicas com o capital alemão .207

8.2 Neutralidade e negócios internacionais 213

CAPÍTULO 9 - A economia brasileira entre as políticas internacionais da Tríplice Entente e da Tríplice Aliança 231

9.1 O governo brasileiro e os negócios internacionais no mundo dividido ....232

9.2 Neutralidade disfarçada e os negócios internacionais 238

CAPÍTULO 10 - Comércio exterior em regime de exceção .250

10.1 Statutory list: estrutura e impactos da lista de exceções na economia brasileira 250

10.2 Comércio exterior

CAPÍTULO 11 - Ascensão dos Estados Unidos na economia internacional: economia brasileira no novo mainstream .288

11.1 A guerra e a acumulação de capital nos Estados Unidos 289

11.2 Estados Unidos e a nova economia internacional .294

CONCLUSÃO .309

ARQUIVOS E BIBLIOTECAS 



\section{INTRODUÇÃO}

A Primeira Guerra Mundial foi a continuação das Guerras Balcânicas. Os dois eventos parecem distantes da formação econômica do Brasil, mas marcaram profundamente a sociedade brasileira nas primeiras décadas do século XX. Como herança para a economia brasileira, estes acontecimentos na Europa deixaram muitos elementos que contribuíram para modificar as características do setor público e do setor privado do país.

Uma das questões que a historiografia tenta responder é se os efeitos da Primeira Guerra Mundial na economia brasileira foram profícuos ou deletérios para industrialização do país. A controvérsia entre os pesquisadores é grande porque a guerra envolveu as atividades econômicas do Brasil de maneiras distintas, e em momentos diferentes, deixando pouco espaço para generalizações. Quando se considera que a economia nacional já passava por problemas crônicos no setor externo e que a situação chegou ao ponto de crise durante as Guerras Balcânicas (1912-3), as afirmações gerais para o período da guerra ficam ainda mais dificultadas. Em 1913, o influxo de capital estrangeiro que o Brasil recebia praticamente cessou e a situação se complicou ainda mais quando as matrizes dos bancos europeus decidiram concentrar os recursos em seus países de origem.

Encontrar a relação entre os Bálcãs, a Primeira Guerra Mundial e a economia brasileira foi o desafio que guiou os objetivos desta tese: identificar como estes eventos externos influenciaram a política econômica brasileira entre 1914-1918, quais foram as respostas que a sociedade brasileira forneceu para enfrentar as crises econômicas que envolveram o Brasil no período e como a economia brasileira reagiu às mudanças que se processaram na economia internacional quando a liderança do Reino Unido foi confrontada, primeiro pelo Império Alemão e, na parte final da Primeira Guerra Mundial, pelos Estados Unidos.

Estes objetivos nasceram do contato com a historiografia que aborda a formação econômica do Brasil. Há poucas análises sobre a economia brasileira na década de 1910. As pesquisas que realizadas sobre o Brasil durante a Primeira Guerra Mundial serviram de fonte de inspiração e levantaram uma questão que esta tese tenta ajudar a responder com outros elementos: como a economia internacional, liderada pela Europa Ocidental e pelos Estados Unidos, saiu de uma situação de desenvolvimento social e econômico para entrar em guerra 
total? Quais foram as raízes da Crise de 1913? Como a economia brasileira reagiu a tantas mudanças no cenário internacional?

Para começar a responder a estas e a outras questões que foram surgindo ao longo das pesquisas, era necessário decifrar as Guerras Balcânicas. Não seria possível entender as influências da Primeira Guerra Mundial no Brasil sem antes estabelecer as ligações entre os eventos de 1912 na Bulgária, os de 1913 na Sérvia, o assassinato do herdeiro do trono AustroHúngaro, Francisco Fernando, e os motivos que levaram duas nações ligadas por suas elites Reino Unido e Alemanha - ao confronto bélico. Estas são ligações complexas que exigiram investigar questões de religião, formação social da região balcânica, questões de fronteira do Império Turco-Otomano, relações sociais entre o Império Russo e o Reino da Sérvia, parcerias estratégicas entre o Império Austro-Húngaro e o Império Alemão, Unificação Alemã, relação histórica entre britânicos e germânicos e mais algumas tantas questões que aparecem nesta tese.

Respondidas estas questões, era o momento de entender como se formou a Crise de 1913 e como este evento afetou a economia brasileira. As pesquisas no Brasil indicaram que seria necessário explorar arquivos e fontes primárias. $\mathrm{O}$ arquivo principal utilizado nesta pesquisa foi o National Archives, em Londres. Este centro de pesquisas em Kew Gardens guarda farta documentação sobre as Guerras Balcânicas, os meandros da Crise de 1913, os fatos que levaram ao fim da Belle Époque e, ponto central, as relações internacionais entre o Brasil e o Império Britânico.

A documentação sobre o Brasil em Londres inclui os registros das transações financeiras e comerciais realizadas pelos governos Hermes da Fonseca e Wenceslau Braz com o Reino Unido e outros países importantes para a história econômica brasileira. Alguns dos temas relacionados geraram documentação em grande quantidade, levando National Archives a criar compêndios específicos para a dívida externa brasileira, o funding loan de 1914 e os processos nos quais o Brasil solicitou ajuda financeira durante o período.

Estes e muitos outros documentos abriram diversas possibilidades de pesquisa sobre a economia brasileira. O tema escolhido para esta tese foi definido com a intenção de contribuir para a historiografia com o estudo sobre um período e sobre temas que não figuram entre os mais investigados sobre o Brasil. A Primeira Guerra Mundial na economia brasileira é um assunto com poucas opções de leitura, muito porque os eventos que levaram à Crise de 1929 
provocaram uma espécie de sombra sobre a década de 1910. Encontrar estudos sobre os impactos da Crise de 1913 na economia brasileira é ainda mais raro.

Estava definido o escopo da pesquisa: os impactos da Crise de 1913 e da Primeira Guerra Mundial na economia brasileira, especialmente como estes acontecimentos afetaram o setor externo e, desta forma, a política econômica do Brasil. Os documentos selecionados incluíram análises da diplomacia britânica e dados diversos sobre o Brasil. Este material aborda, por exemplo, movimentação de carga nos portos brasileiros, dívida externa do Brasil, solicitações do governo para a concessão de crédito, carga tributária, situação política e social, câmbio, bancos, relações diplomáticas do Brasil com os países vizinhos, relações internacionais do Brasil com o Império Alemão, os Estados Unidos e com a França, além de relatórios semanais elaborados pela representação diplomática do Reino Unido no Brasil.

À época, o Brasil ainda não mantinha relações internacionais com o Reino Unido na forma que a diplomacia considera como de "alto grau": não havia embaixada britânica no Brasil e, naturalmente, Londres não contava com embaixada brasileira. As relações entre os dois países eram centralizadas em representações diplomáticas. A do Reino Unido no Rio de Janeiro ficou a cargo de Arthur Peel durante a maior parte do período pesquisado. A representação brasileira em Londres foi exercida, em parte do período, com apoio da estrutura do Banco do Brasil. A proximidade entre o Banco do Brasil e as relações internacionais do Brasil foi extensa e complexa, merecedora de um capítulo específico.

As fontes primárias em Londres foram confrontadas, quando possível, com análises feitas na própria, principalmente em material elaborado pelo Ministério da Fazenda, pela Presidência da República e pela imprensa brasileira, especialmente $O$ Estado de S. Paulo e o Jornal do Commercio. Como complemento, foram utilizados os arquivos da Coleção Wileman Brazilian Review, especialmente sobre o período da Caixa de Conversão, sobre as investigações que o Reino Unido realizou sobre as relações entre o Brasil e o Império Alemão e para relatos sobre o câmbio e as cotações para o café e para a borracha. Material de fonte secundária, escrito por autores que vivenciaram o período, serviu como contraponto histórico.

Como o período pesquisado é praticamente o mesmo que Wenceslau Braz ocupou a presidência da República, diversos assuntos envolveram o ex-presidente e os principais nomes do seu governo: João Pandiá Calógeras, ministro da Fazenda, e Lauro Müller, ministro das Relações Internacionais. Sobre Wenceslau Braz, os arquivos em Londres guardam pouca 
informação. O nome do ex-presidente aparece principalmente em documentos que analisaram a política brasileira. Para os arquivos sobre a economia do Brasil, Calógeras teve destaque. O ex-ministro da Fazenda ocupou a pasta durante a maior parte da Primeira Guerra Mundial, participando de momentos críticos que exigiram mudanças de rumo na política econômica brasileira. Estas mudanças necessitaram algum tipo de anuência, crédito ou remessa de recursos do Reino Unido para o Brasil. Para Lauro Müller, a diplomacia britânica preparou dossiês que abordaram aspectos da vida pessoal do ex-chanceler brasileiro e de suas relações com o Império Alemão. A ascendência germânica de Müller suscitou muito debate entre Londres e o Rio de Janeiro. O governo britânico levantava suspeitas, nunca comprovadas, de envolvimento do ex-ministro das Relações Exteriores com o Império Alemão. Interessante foi observar que a saída de Müller do comando da pasta foi motivo de lamento da representação diplomática britânica no Rio de Janeiro.

O confronto dos dados obtidos em Londres, com dados oficiais sobre o Brasil - muito especialmente os relatórios do Instituto Brasileiro de Geografia e Estatística -, com relatos na imprensa brasileira, análises do governo brasileiro, debates no Congresso Nacional, avaliações do Banco do Brasil e dados da Coleção Wileman resultou na divisão da tese em três partes que abordam os principais destaques dos impactos da Crise de 1913 e da Primeira Guerra Mundial na economia Brasileira.

A primeira parte analisa o cenário do Brasil antes da Primeira Guerra Mundial. Esta análise inclui a avaliação dos elementos que levaram os países balcânicos a duas guerras entre 1912-1913 e como estas guerras se transformaram na Crise de 1913. Foi uma crise essencialmente financeira que afetou o comércio exterior e o câmbio no Brasil. A segunda parte estuda a economia brasileira durante a Primeira Guerra Mundial. Nesta parte foram avaliadas as consequências econômicas da posição de neutralidade assumida pelo Brasil. Questões como o processo que resultou no funding loan, as consequências das restrições na economia internacional sobre os orçamentos públicos do Brasil, as respostas que o ministro da Fazenda, Pandiá Calógeras, conseguiu estruturar para combater os efeitos da guerra nos negócios do Brasil, a atuação do Banco do Brasil no setor externo da economia brasileira e, fechando a primeira parte, como foi a intermediação bancária dos negócios brasileiros que as casas Rothschild e Schröder desenvolveram. Na terceira parte estão os negócios internacionais do Brasil durante a guerra. Aqui, foram abordadas as relações econômicas do Brasil com o Império Alemão, como a economia brasileira se desenvolveu entre as políticas 
internacionais da Tríplice Entente e da Tríplice Aliança, como o comércio exterior do Brasil reagiu à lista de exceções estabelecida pelos países aliados, quais foram as principais alterações na pauta de produtos comercializados pelo Brasil durante o regime de exceção e, fechando esta terceira e última parte, quais foram os caminhos que levaram os Estados Unidos a assumir posição de liderança na economia internacional e como esta mudança envolveu a economia brasileira.

As guerras nos Bálcãs são o ponto de partida para o entendimento da Crise de 1913, da Primeira Guerra Mundial e das mudanças na economia brasileira durante o período pesquisado. A Primeira Guerra Balcânica ocorreu em 1912 e foi motivada por disputas territoriais e logísticas entre o Império Turco-Otomano e a Liga Balcânica, composta por Bulgária, Sérvia, Montenegro e Grécia. Os países da Liga Balcânica mantinham há muito relações conflituosas com a Turquia que havia sido o poder dominador da região até o estabelecimento dos austríacos. O enfraquecimento do Império permitiu o levante de questões locais. Estas questões tiveram apoio do Império Russo, interessado nas possibilidades de negócios que as rotas de comércio que passavam pela região poderiam oferecer. Com a derrota da Turquia, a Bulgária aproveitou sua superioridade bélica para fazer valer os seus interesses sobre os outros países da região. Esta foi a Segunda Guerra Balcânica (1913). O Reino da Sérvia, com apoio da Rússia, conseguiu enfrentar e derrotar os búlgaros e anexar territórios na região.

O Império Austro-Húngaro era, oficialmente, o país que controlava os Bálcãs. Forças militares austríacas já estavam posicionadas aguardando o desfecho dos conflitos na região. $\mathrm{O}$ maior receio de Viena era que a Sérvia se transformasse em liderança local. A Alemanha, aliada dos austríacos, temia a expansão dos russos. Ao final da Segunda Guerra Balcânica, quando ficou comprovado que estas duas possibilidades se concretizaram, a Áustria decidiu afrontar o poder dos sérvios. Viena não estava sozinha. A Alemanha foi a grande incentivadora do retorno das investidas na região. Em visita oficial a Sarajevo, o herdeiro do trono austro-húngaro foi assassinado por lideranças comandadas por Belgrado.

A Primeira Guerra Mundial teve início oficial ao final de julho de 1914 quando se esgotaram as negociações entre o Império Austro-Húngaro e o Reino da Sérvia sobre as investigações para apurar o assassinato de Francisco Fernando. O caso estava encerrado para os sérvios porque Gavrilo Princip teria sido o único responsável pelo atentado. Para os austríacos, as investigações teriam que ser conduzidas sem limites porque eles acreditavam no 
envolvimento direto de Belgrado em um complô organizado, impossível de ter sido executado apenas pelo estudante sérvio.

As hostilidades que começaram a 28 de julho tomariam proporções inesperadas, mas representaram para os povos balcânicos a continuidade das guerras de 1912-3. Em termos financeiros, sentimento análogo foi percebido no Brasil porque o país estava em crise aguda antes da guerra, desde que as restrições ao crédito europeu e a diminuição nas exportações de café e de borracha forçaram nova consolidação da dívida externa (capítulo 1).

A crise de 1913 levou à restrição de crédito na economia internacional. Os reflexos no Brasil foram negativos porque houve reversão nas expectativas positivas que os negócios internacionais poderiam trazer para o mercado interno. As importações não puderam mais ser financiadas, o déficit público em ouro aumentou e a Caixa de Conversão não pode mais emitir notas conversíveis devido à desvalorização do mil-réis (capítulo 2).

O começo das hostilidades na Europa provocou atraso na liberação dos recursos em ouro por meio do funding loan e muitos problemas para a economia brasileira. O dinheiro novo do funding entrou, mas o alívio foi passageiro porque o orçamento brasileiro necessitava de recursos contínuos para atender despesas em ouro e em papel que mesmo com a guerra ficavam acima das receitas obrigando o governo a tentar estratégias diversas para financiar o déficit (capítulo 3).

Como a economia internacional estava operando agora em regime excepcional, o governo federal tentou substituir as rendas aduaneiras por tributos como o imposto sobre o consumo e sobre a renda. Foi estabelecido aumento na quota-ouro para fazer frente à diminuição na entrada de moeda conversível. Houve tentativas de ampliação de outros tributos como o imposto sobre o selo, sobre profissões e o imposto sobre a renda (capítulo 4).

A falta de recursos levou o ministro Calógeras a retomar as emissões de curso forçado para atender a demanda do setor público, abastecer o comércio e os bancos. Esta mudança provocou críticas de todos os setores porque provocou oscilação na taxa de câmbio que era o elemento balizador para os negócios no Brasil (capítulo 5).

As mudanças na política econômica elevaram o Banco do Brasil à categoria de principal agente financeiro do governo. A instituição foi modificada para poder participar de negociações internacionais em operações complexas, como a venda de café para estoques do 
governo Britânico como barganha para a obtenção de libras esterlinas destinadas ao pagamento dos serviços da dívida externa e fornecimento de divisas para as importações que geravam rendas aduaneiras, principal fonte de receitas do país (capítulo 6).

As operações internacionais do Banco do Brasil durante a guerra tiveram a participação das casas bancárias Rothschild e Schröder que foram os principais bancos estrangeiros utilizados pelo Brasil para viabilizar as exportações e a concessão de crédito em contexto de economia internacional avessa a riscos e que passou a concentrar ouro nos países beligerantes para financiar uma guerra que aos poucos deixou de ser simplesmente mais um conflito passageiro para se tornar a maior guerra vivenciada no mundo até então (capítulo 7).

Antes da guerra, as relações econômicas entre o Brasil e o Império Alemão tinham alcançado elevado grau de complexidade, envolvendo valores elevados que tiveram como base negócios com o café brasileiro. Empresas alemãs se especializaram como agentes da commodity e criaram redes em várias partes da Europa que permitiam a estocagem e a venda do produto. Quando do início da guerra, estes negócios com os alemães sofreram mudanças ou foram paralisados (capítulo 8).

As alterações nos negócios do Brasil com a Alemanha foram impostas pelo Reino Unido que convenceu os países da Entente a implantar a lista de exceções - statutory list - que previa sanções às empresas que tivessem relação com empresas de capital alemão. O objetivo era impedir a Alemanha de ter acesso a recursos em ouro que pudessem ser utilizados como força bélica. A lista de exceções classificou o café brasileiro como alvo de contrabando, alterando o mercado internacional do produto (capítulo 9).

A lista de exceções foi responsável por alterações na pauta de importação e exportação do Brasil. Houve possibilidade exportação de novos produtos, alguns industrializados, mas a redução nas vendas internacionais de café foi o fator preponderante para a economia brasileira neste período. O governo brasileiro mostrou como as restrições às exportações brasileiras afetavam a atividade econômica do país. As respostas dos britânicos eram baseadas mais no receio de que outros países assumissem o seu lugar como líderes do comércio internacional do Brasil (capítulo 10).

O governo britânico estruturou planos para manter o Brasil em sua área de influência, os Estados Unidos passaram antes do fim da guerra a centralizar importantes atividades econômicas do Brasil. Esta passagem de poder ocorreu quando o capital norte-americano 
começou a financiar o Tesouro Britânico. Foram lançados milhões de dólares em títulos que abasteciam os cofres britânicos. Parte dos recursos que os Estados Unidos estavam obtendo com a guerra se transformou em oferta de ajuda para o Brasil transferir a dívida externa para Washington (capítulo 11).

Das Guerras Balcânicas até a passagem do poder na economia internacional para os Estados Unidos foram milhares de documentos pesquisados, a maioria fotografados, que podem ser úteis para futuras pesquisas que tenham o Brasil e a economia internacional como objeto de estudo. 


\section{Parte I - O cenário externo do Brasil antes da Primeira Guerra Mundial}

\section{Capítulo 1 - Impactos da crise internacional no financiamento externo brasileiro}

A economia mundial estava enfrentando grave crise internacional em 1913. Não foi diferente na economia brasileira: exportações da borracha e do café em baixa, somadas à carência de crédito internacional, comprometeram a atividade econômica. O cenário internacional ruim foi uma grande surpresa para o mundo dos negócios. Eram tempos de belle époque e nada no horizonte indicava problemas como os que surgiram a partir de 1912.

Tudo começou nos Bálcãs, local de grande interesse para o comércio internacional, onde a civilização ocidental convivia em desarmonia com a oriental. A região era alvo de interesses de impérios: russos, turcos e alemães disputavam espaço com poderes locais, como os búlgaros e os sérvios. A situação era de tensão constante, especialmente após a segunda metade do século XIX. Tanto tempo de conflitos fez com que a região balcânica passasse a ser interpretada pelas potências europeias - França, Império Britânico e Império Alemão como de risco circunscrito, com poucas de chances de contágio para outros países.

A Primeira Guerra Balcânica ocorreu em 1912. A Segunda, em 1913. Estes conflitos mostraram aos europeus que eles estavam equivocados em suas análises. A região podia, sim, alterar o rumo das relações internacionais do continente. Clima de apreensão levou as principais praças financeiras da Europa a trabalhar com um cenário de restrição de recursos. Foi este o ponto que colocou a economia brasileira em crise. $\mathrm{O}$ país necessitava de financiamento externo de maneira regular. Como a crise tornou o acesso ao ouro internacional mais difícil, o Brasil foi obrigado a mudar a condução das exportações. O objetivo foi tentar cobrir as perdas com as vendas de café e encontrar uma maneira de recuperar a fatia do país no mercado da borracha.

Antes do início da Primeira Guerra Mundial, o setor externo brasileiro foi profundamente alterado. O cenário no qual estas alterações ocorreram e as soluções que o governo tentou engendrar serão abordados no Capítulo 1. 


\section{Seção 1.1 As guerras nos Bálcãs e a crise internacional de 1913}

Desde o século XVI, com a expansão do islamismo na direção da fronteira sudeste da Europa, há registros de muitas e intensas batalhas na península balcânica. Estas contendas tiveram como motivo central o choque cultural entre cristãos estabelecidos na região desde o início do Império Bizantino e islâmicos que passaram a se fixar no território como resultado das investidas militares da Anatólia sobre a Europa, Ásia e África. As vitórias e avanços dos islâmicos foram aos poucos formando o Império Turco-Otomano que se transformou na grande ameaça aos estados europeus, principalmente os regimes instalados na parte oriental e central do continente, com destaque para a Áustria. As forças otomanas sobre a Europa somente foram imobilizadas a partir da Batalha de Mohács (1526) quando os Habsburgos impediram a capitulação de Viena e lograram a libertação da Hungria e de parte dos Bálcãs. Começavam neste momento as inúmeras hostilidades entre o Império Austro-Húngaro e o Império Turco-Otomano. ${ }^{1}$

A religião sempre foi usada como motivo maior para os conflitos nos Bálcãs porque em um mesmo país havia uma maioria cristã ou islâmica, e com o enfraquecimento do Império Otomano e o consequente abandono do sistema millet - dhimmi, as diferentes culturas não mais terão a chance de convivência pacífica. As disputas foram ganhando vulto à medida que os interesses econômicos na península foram aumentando e, com o avanço da tecnologia aplicada à indústria bélica a partir da segunda metade do século XIX, guerras importantes como a Russo-Turca de 1877-8, que resultou no Tratado de Santo Estevão, deram o tom para as hostilidades que aconteceriam no início do século XX. O Império Alemão foi o maior crítico das resoluções deste tratado e rapidamente estruturou o Congresso de Berlim, para dar novo concerto aos estados balcânicos. Os alemães estavam interessados no espólio do Império Austro-Húngaro e foram, aos poucos, projetando as mudanças que, vigorosamente contestadas pelos russos, eclodiriam na Primeira Guerra Mundial. ${ }^{2}$

A curta duração do Tratado de Santo Estevão indica exatamente como as relações internacionais ocorriam nos Bálcãs e porque os europeus, vizinhos e primeiros interessados, foram aos poucos se descuidando das consequências que as pendências locais poderiam ter no ocidente. A lógica do pan-eslavismo ficou complexa demais para as elites europeias que

\footnotetext{
${ }^{1}$ Hall, The Balkan Wars, 1912-1913 - Prelude to the First World War, p. 1-21

2 Ibidem.
} 
passaram a encarar os impactos econômicos que outra guerra balcânica pudesse provocar como assunto de chancelaria. Daí a surpresa com a evolução das guerras de 1912-1913 que, de apenas mais um problema regional, se transformaram em crise mundial, com amplo impacto na economia brasileira que não pode mais se financiar com recursos internacionais como o país fazia até o início das guerras nos Bálcãs. ${ }^{3}$ Os impactos desta mudança da economia internacional no Brasil são o tema da seção 1.2.

A proximidade entre culturas que há muito se chocavam por visões diferentes sobre a organização social, em área de grande e tradicional relevância para o comércio internacional, teria que resultar em conflitos, vários destes nos Bálcãs. Dois dos mais ruidosos e relevantes para os povos das nações envolvidas e para o estudo que se empreende foram a Primeira Guerra Balcânica (1912) e a Segunda Guerra Balcânica (1913). Estes enfrentamentos, constituídos por diversas batalhas que deixaram marcas indeléveis, perderam parte da importância que lhes cabe justamente por significarem, ipso facto, o início não oficial da Primeira Guerra, grande marco no mundo ocidental. Para o sudeste europeu, no entanto, os eventos de 1914 nada mais foram que a continuação das guerras balcânicas. ${ }^{4}$

As atenções dos europeus em 1912 estavam voltadas para o progresso científico e tecnológico e para o consequente avanço na qualidade de vida que o longo período de paz estava proporcionando ao continente, afinal era a Belle Époque e a última grande guerra na região, a Franco-Prussiana, ocorrera há mais de quarenta anos. Um novo embate, se sobreviesse, teria que se dar no campo do previsível: Reino Unido contra o Império Alemão ou o Império Russo contra o Império Austro-Húngaro. Até mesmo líderes treinados na interpretação aguda das relações internacionais, como o presidente francês Poincaré, não cogitavam uma escalada bélica a partir dos Bálcãs por acreditarem que tudo haveria de ser resolvido como em outras ocasiões nas quais a autoridade Otomana nestes territórios foi contestada, isto é, por meio de guerras circunscritas. No entanto, vozes inauditas, como o embaixador romeno em Paris, conhecedor das idiossincrasias culturais de sua região, alertavam para a fragilidade do concerto das nações que operava no Sudeste da Europa e viam a sombra dos débeis impérios de Viena e de Moscou na vigia do desenrolar dos fatos. ${ }^{5}$

De todas as guerras entre Otomanos e Habsburgos, as que deixaram marcas mais perenes na história foram as guerras balcânicas do início do século XX porque concentraram

\footnotetext{
${ }^{3}$ Hall, The Balkan Wars, 1912-1913 - Prelude to the First World War, p. 22-79.

${ }^{4}$ Schurman, The Balkan Wars, 1912-1913.

${ }^{5}$ MacMillan, The War That Ended Peace, p. 436-512.
} 
os elementos que levariam ao fim dos dois impérios e ao início da guerra (1914-1918). Estas guerras foram essencialmente duas, inspiradas nos processos de unificação da Itália (1861) e da Alemanha (1871) e que encorajaram a formação da Liga Balcânica, a Primeira Guerra Balcânica e a Segunda Guerra Balcânica. A Primeira Guerra dos Bálcãs ocorreu entre outubro de 1912 a maio de 1913 e foi composta por batalhas entre a Liga Balcânica (Sérvia, Montenegro, Grécia e Bulgária) e o Império Otomano. O Império Austro-Húngaro apoiou a Liga Balcânica como se estivesse participando diretamente das batalhas, isto porque os interesses em jogo eram demasiadamente importantes para que riscos fossem corridos. Nesta fase, o apoio do Império Alemão fez toda a diferença e os turcos foram derrotados, modificando radicalmente o mapa político nos Bálcãs que, sem a estrutura do Império Otomano que os unia, entrou em convulsão resultando na Segunda Guerra Balcânica, nos meses de junho e julho de $1913 .^{6}$

Durante a Segunda Guerra Balcânica, os estados europeus ocidentais perceberam que o conflito poderia não ficar restrito ao leste do continente porque os interesses envolvidos ultrapassavam em muito as questões de disputas nacionalistas e religiosas entre islâmicos e cristãos. O que estava no topo das inquietações dos governos europeus eram territórios que o Império Turco-Otomano e o Império Austro-Húngaro estavam prestes a perder para o novo jogo de forças na Europa. O Império Turco-Otomano estava dando sinais de fraqueza já há bastante tempo, como ficou evidente no embate de forças com o Império Russo no final do século XIX que venceu os turcos mais por demérito de Anatólia do que propriamente por capacidade militar e tecnológica do país das estepes. Vale lembrar que, pouco antes da questão balcânica, as forças de Moscou foram humilhadas na guerra contra o Japão (1905), evento essencial para o entendimento do fim do czarismo e da mudança de rumo que o papel dos russos terá em 1917.

Apesar dos sinais de flebilidade, questões étnicas sempre falam mais alto, e com o pan-eslavismo não foi diferente, porque era assaz natural que a saída dos turcos dos Bálcãs abrisse espaço para a ampliação, de fato, dos mandos russos na região. O problema era que alguns destes espaços, como os ocupados à época pela Bósnia e pela Sérvia, estavam nas mãos do Império Austro-Húngaro que se agarrava à região como forma de segurar os últimos laços do Império, e uma possível ampliação dos interesses russos na região seria prontamente rechaçada por Viena. Se os autríacos estivessem atuando por conta própria neste cenário de

\footnotetext{
${ }^{6}$ Ver Buescu, O reerguimento econômico (1903-1913). Buescu, autor de origem romena, considera que os conflitos no sudeste europeu foram periféricos para a formação da nova ordem econômica mundial.
} 
guerra, é bastante provável que a crise econômica de1913 não tivesse ocorrido. Assim como laços étnicos sempre unirão russos e sérvios, os austríacos, conhecidos como alemães do leste, sempre terão laços encadenados com a Alemanha. Assim como o Império Turco-Otomano, o Império Austro-Húngaro estava nos estertores de sua existência. O Império Alemão era a nova potência militar e tecnológica que estava pronto para a ampliação do seu domínio regional e os Bálcãs serviam a contento como cenário para a execução dos planos teutônicos. ${ }^{7}$

Este roteiro das relaçoes internacionais era conhecido pelos líderes europeus, principalmente pelo Reino Unido que começava a ver que as relações familiares que uniam as casas de George V e Wilhelm II não seriam suficientes para limitar a expansão da Alemanha e que a questão balcânica poderia acabar por se transfigurar em algo com condições de ameaçar os interesses britânicos, como viria mesmo a ocorrer em 31 de julho de 1914, quando o Império Alemão emite ultimato ao Império Russo em relação à Sérvia. A noção dos riscos que a Segunda Guerra Balcânica evidenciou em 1913 colocou em marcha planos de contingência econômica nos principais países europeus e em suas colônias. Estes planos estes consubstanciados em Tesouros de Guerra, regras financeiras com o objetivo de represar capitais no próprio país, restringindo investimentos no exterior, tanto na forma de inversões produtivas quanto para o financiamento do comércio exterior, como o fizeram os bancos centrais da Itália, França, Império Russo, Império Austro-Húngaro e Império Alemão. ${ }^{8}$

A ordem passa a ser entesourar ouro, literalmente, para a chancela da máquina de guerra e para a manutenção do funcionamento da economia interna em um período de estrangulamento externo. O Império Britânico, o maior avalista e securitizador da dívida brasileira desde D. Pedro II, partiu para uma ofensiva financeira sem precedentes para com os seus negócios no Brasil com o objetivo de obter os recursos devidos em pendências comerciais que se arrastavam há muitos anos, algumas datando do final do século XIX. A pressão para estes casos fossem solucionados aumentou consideravelmente em $1913 .{ }^{9}$

Com os europeus em geral restringindo a aplicação dos seus capitais no exterior e como os Estados Unidos ainda estavam ensaiando a proeminência do fluxo financeiro internacional, o Brasil dependente do ouro das exportações para o comércio interno e para as

\footnotetext{
${ }^{7} \mathrm{O}$ conflito nos Bálcãs elevou em muito as encomendas junto à indústria metalúrgica alemã. O caso das Indústrias Krupp é sintomático. O Estado de S. Paulo, 16 fevereiro1913, p. 4.

${ }^{8}$ Entrevista com Pandiá Calógeras. O Estado de S. Paulo, 13 julho1914, p. 7.

9 'Brazilian Loan and British Claims', 20 julho 1914, FO 371/1916/32788, p. 159
} 
necessidades de financiamento público ${ }^{10} \mathrm{~A}$ dimensão desta crise dependeu de idiossincrasias que, no caso brasileiro começavam no orçamento público, historicamente deficitário tanto em ouro quanto em papel. ${ }^{11}$

A solução para a falta de cobertura em papel foi a emissão de moeda em curso forçado, mas, desde o final de 1906, com a Caixa de Conversão em funcionamento, este tipo de operação ficou dificultado e o risco de restrições na base monetária passou a ser uma constante. A Caixa de Conversão foi criada pela Lei $\mathrm{n}^{\circ}$ 1575, de 6 dezembro 1906, durante o governo do presidente Afonso Pena, com a finalidade de manter a estabilidade cambial, atendendo a uma das mais fortes demandas da economia cafeeira que temia a continuidade da valorização do mil-réis que, para tanto, emitia cédulas garantidas por lastro em moedas de ouro de curso legal, nacionais e estrangeiras, como o marco alemão, o franco francês, a libra esterlina e o dólar norte-americano. Essas cédulas eram consideradas "ouro" por que podiam ser trocadas por moedas conversíveis ou por mil-réis à taxa fixada para as operações da Caixa. $^{12}$

Para as necessidades do orçamento em ouro, a economia nacional contava com o superávit comercial e com o suporte de bancos estrangeiros, tanto para empréstimos quanto para a viabilização do comécio exterior, por meio do adiantamento de cambiais ou o do subsídio das letras de importação. Com as medidas de guerra tomadas pelos europeus, o financiamento externo coordenado a partir de Londres, a principal praça financeira internacional para os negócios brasileiros, ficou extremamente dificultado, e é por esta porta que a crise de 1913 entrou na economia brasileira: sem os recursos em ouro do exterior, a economia passou por uma inflexão muito acentuada antes da Primeira Guerra, primeiro porque faltaram recursos em ouro para fechar o déficit público e, depois, porque faltaram divisas em moeda forte para financiar as exportações e importações e, sem financiamento, o comércio exterior perdeu fôlego.

O que já seria um problema profundo foi ampliado pela dependência da renda interna do Brasil em relação à externa. Com as dificuldades das operações financeiras internacionais sobrevindas com as guerras nos Bálcãs, a economia interna foi diretamente atingida porque agora não havia mais a possibilidade de o governo obter em Londres aqueles três ou quatro

\footnotetext{
${ }^{10}$ A palavra ouro é usada neste estudo para designar tanto o metal propriamente dito quanto moedas conversíveis em ouro, especialmente a libra esterlina, mas também o franco francês, o marco alemão e o dólar americano.

${ }^{11}$ A palavra papel, no contexto da história cambial e financeira do Brasil, é utilizada como sinônimo de moeda não conversível.

${ }^{12}$ Hadba, Caixas de conversão.
} 
milhões de libras emergenciais, considerados rotineiros pelos banqueiros britânicos, e a crise se instalou com força no Brasil, particularmente no segundo semestre de 1913. Em outros países com economia também dependente do setor externo, como a Argentina, a atividade econômica foi comprometida em razão da redução do preço do trigo e do couro, indicador de que a crise teve força para atingir mesmo o comércio de produtos com grau de elasticidade menor que o café. No contexto da economia argentina, Guglielmo Ferro escreveu artigo no jornal La Nación no qual explicita o receio do que poderia suceder se o conflito nos Bálcãs se ampliasse e os atritos entre as grandes potências europeias se confirmassem. ${ }^{13}$

Dada a alta dependência da economia brasileira em relação ao setor externo, as exportações sempre tinham singular importância porque eram a principal fonte de ouro do país, metal que servia como pagamento das importações que, taxadas com o imposto sobre consumo de produtos importados, compunham a principal fonte de receita pública do período, as rendas aduaneiras. Como já ocorria desde o final do século XIX, as exportações em 1913 eram principalmente compostas pelo café, que desde 1850 liderava a pauta, e a borracha, produto que ganhou grande destaque no início do período republicano, mas que não conseguiu manter sua posição após a crise dos Bálcãs, porque o artigo teve os preços drasticamente reduzidos ao longo do ano de 1913, tanto por ter sofrido com a queda na demanda interna dos Estados Unidos, quanto porque as novas áreas de produção no sudeste asiático aumentaram excepcionalmente os estoques globais, praticamente eliminando a contribuição do produto como fonte de metal para a Caixa de Conversão.

A importância da borracha para a pauta de exportações brasileiras no início do século XX foi tanta que o produto alcançou praticamente $30 \%$ do total exportado na primeira década, tal como se verifica na Tabela 1.1 .

Tabela 1.1 - Principais mercadorias exportadas, Brasil, 1871 - 1930 (\% sobre valor total).

\begin{tabular}{l|r|r|r|r|r|r}
\hline \multicolumn{1}{c}{ Café } & \multicolumn{1}{c}{ Açúcar } & \multicolumn{1}{c}{ Algodão } & Peles e Couros & \multicolumn{1}{c}{ Borracha } & \multicolumn{1}{c}{ Total } \\
\hline $1871 / 80$ & 56,44 & 11,87 & 9,51 & 5,52 & 5,49 & 88,83 \\
$1881 / 90$ & 61,70 & 9,96 & 4,24 & 3,19 & 7,69 & 86,78 \\
$1891 / 00$ & 63,84 & 5,66 & 2,48 & 2,48 & 15,83 & 90,29 \\
$1901 / 10$ & 51,46 & 1,24 & 2,12 & 4,36 & 27,94 & 87,12 \\
$1911 / 20$ & 52,40 & 3,19 & 1,98 & 6,41 & 11,44 & 75,42 \\
$1921 / 30$ & 69,56 & 1,44 & 2,41 & 4,62 & 2,50 & 80,53 \\
\hline
\end{tabular}

Fonte: Anuário Estatístico do Brasil (1952) - Instituto Brasileiro de Geografia e Estatística. Rio de Janeiro, 1953, p. 284.

13 “A Salvação da Lavoura”, O Estado de S. Paulo, 21 janeiro 1914, p. 6. 
A borracha foi o único produto a ameaçar a preponderância do café nas exportações entre as décadas de 1870 e 1930 e foi por esta razão que a crise pela qual este produto passou ao final da primeira década do século XX foi fator considerável para a ampliação da crise de 1913. Pode mesmo ser afirmado que, ao coincidir com a Guerra nos Bálcãs, a supressão nas vendas da commodity no mercado internacional elevou em muito a necessidade de ouro, agravando os problemas de financiamento das exportações, cobertura do déficit público e arrecadação aduaneira para desaguar na carência de crédito para os negócios internos.

Em 1913, a oferta global de café, ao contrário do que se passava com a borracha, dependia essencialmente da produção do Brasil, que controlava os preços por intermédio do Comitê de Valorização do Café atuante na totalidade do negócio, basicamente para evitar a superprodução: no plantio, controlando o número de novos pés de café e eliminando cafezais prontos para a colheita; e no ajuste dos estoques em Santos, no Rio de Janeiro, e nas principais praças da Alemanha, França e Reino Unido e dos Estados Unidos, sempre em parceria com agentes locais, especialmente na Alemanha e no Reino Unido, países que se notabilizaram como os maiores agenciadores do café do Brasil no mercado internacional. Apesar de todo este aparato de operação de truste não foi possível segurar os preços em 1913, graças à força da crise, mas também por obra de um elemento novo e que trouxe mudanças radicais para a cafeicultura brasileira: o combate ao truste do café patrocinado pela Secretaria da Justiça dos Estados Unidos. O mercado norte-americano já compunha parcela considerável da demanda global de produtos brasileiros, como pode ser visto na Tabela 1.2 que mostra a ascensão das exportações para os norte-americanos sobre a fatia dos europeus, que foi se ampliando com mais intensidade a partir das guerras nos Bálcãs, até atingir 17,5\% em 1914. 
Tabela 1.2 - Principais destinos das exportações, Brasil, 1901-1914 (\% sobre valor total).

\begin{tabular}{|c|c|c|c|c|c|}
\hline \multirow{2}{*}{\multicolumn{2}{|c|}{ Argentina }} & \multicolumn{4}{|c|}{ Alemanha, Reino } \\
\hline & & $\begin{array}{c}\text { Estados } \\
\text { Unidos }\end{array}$ & $\begin{array}{l}\text { Unido, } \\
\text { Bélgica, França, Itália, } \\
\text { Holanda. }\end{array}$ & Japão & Total \\
\hline 1901 & 13,5 & 12,4 & 55,5 & 0,0 & 81,5 \\
\hline 1902 & 9,0 & 12,3 & 55,1 & 0,0 & 76,3 \\
\hline 1903 & 9,0 & 11,3 & 56,8 & 0,0 & 77,0 \\
\hline 1904 & 10,3 & 11,1 & 56,8 & 0,0 & 78,2 \\
\hline 1905 & 11,8 & 10,3 & 56,3 & 0,0 & 78,4 \\
\hline 1906 & 10,6 & 11,5 & 59,5 & 0,0 & 81,6 \\
\hline 1907 & 9,0 & 12,8 & 62,0 & 0,0 & 83,8 \\
\hline 1908 & 10,1 & 12,1 & 61,3 & 0,0 & 83,5 \\
\hline 1909 & 10,0 & 12,4 & 60,7 & 0,0 & 83,1 \\
\hline 1910 & 8,5 & 12,8 & 62,6 & 0,0 & 83,9 \\
\hline 1911 & 7,6 & 13,3 & 63,4 & 0,0 & 84,4 \\
\hline 1912 & 7,5 & 15,6 & 61,7 & 0,0 & 84,8 \\
\hline 1913 & 7,4 & 15,7 & 61,9 & 0,1 & 85,1 \\
\hline 1914 & 9,6 & 17,5 & 56,1 & 0,0 & 83,3 \\
\hline
\end{tabular}

Nota-se que a importância dos Estados Unidos para as exportações brasileiras já vinha acima dos $10 \%$ do total desde 1901, indicando que o mercado norte-americano rivalizou e superou as exportações aos argentinos durante praticamente todo o período exposto na Tabela 1.2. O avanço dos Estados Unidos ma fatia dos negócios internacionais do Brasil ocorreu com base nas exportações de café, e este avanço foi tal que as operações do produto em Nova York eram vistas como ameaça à posição da praça de Londres na referência de preços do produto no mercado internacional e, por isso, os passos da Bolsa do Café de Nova York eram acompanhados com meticulosa atenção pelos agentes britânicos de café, no Brasil e no Reino Unido. $^{14}$

O café brasileiro não teve vida fácil em Nova York. O sistema de controle de preços praticado pelo Brasil a partir do Convênio de Taubaté (1906) foi criticado nas principais praças, mas a questão da liberdade comercial, principalmente para produtos importados consumidos pelos norte-americanos, era cara nos Estados Unidos, e esta prática cartelizada foi combatida por meio da lei Sherman de 1890, norma jurídica que visava à concorrência por meio do combate aos trustes. Com o café enfrentando o mesmo rigor que a luta contra os

${ }^{14}$ Coleção Wileman, "Brazilian Review" e "Mostly About Cofee", especialmente informações publicadas na seção "Coffee" no primeiro semestre de 1914. 
monopólios durante o governo de Theodore Roosevelt, quando setores como o do aço, petróleo e de transportes foram forçados a abandonar o controle de preços e do mercado, malgradas todas as muitas tentativas da diplomacia brasileira e dos agentes estabelecidos no mercado norte-americano. Os estoques estratégicos de café em Nova York tiveram que ser vendidos, provocando baixa nos preços da commodity e restrição na transferência de ouro para cobrir o déficit brasileiro, situação que colocava o país, mais uma vez, nas mãos dos banqueiros internacionais. ${ }^{15}$

A crise não ficou restrita às exportações e provocou desabastecimento de produtos importados, por absoluta carência de crédito e de ouro ao final do segundo semestre de 1913. No começo do século XX, os fornecedores estrangeiros de produtos ao Brasil estavam concentrados na Europa e nos Estados Unidos, como mostra a Tabela 1.3 que ilustra a distribuição das importações por países de origem entre 1901 e 1914. Em 1913, não houve interrupção na logística do comércio internacional, como foi o caso durante o bloqueio marítimo durante a guerra, e o fornecimento de artigos importados continuou disponível, especialmente dos Estados Unidos, país que vinha contribuindo há bastante tempo com cifras elevadas do total importado pelo Brasil. Em 1901, os norte-americanos já participavam com $43 \%$ dos bens de origem estrangeira consumidos no mercado brasileiro e esta fatia do mercado de importados no Brasil se manteve até 1914, quando somou 40,6\%, indicando que a dependência do suprimento a partir de fornecedores europeus foi dividida com empresas estabelecidas nos Estados Unidos.

Tabela 1.3 - Principais origens das importações, Brasil, 1901 - 1914 (\% sobre valor total)

\begin{tabular}{cccc}
\multirow{2}{*}{ Argentina } & $\begin{array}{c}\text { Estados } \\
\text { Unidos }\end{array}$ & Alemanha, Grã \\
Bélgica, França, Itália,
\end{tabular}

\begin{tabular}{l|l|l|l|l|l}
1901 & 2,2 & 43,0 & 47,8 & 0,0 & 93,0 \\
1902 & 2,8 & 37,0 & 51,9 & 0,0 & 91,7 \\
1903 & 2,1 & 41,3 & 50,2 & 0,0 & 93,6 \\
1904 & 2,8 & 50,4 & 40,0 & 0,0 & 93,2 \\
1905 & 3,1 & 41,1 & 46,7 & 0,0 & 90,9 \\
1906 & 3,6 & 35,1 & 52,5 & 0,0 & 91,2 \\
1907 & 3,2 & 32,2 & 56,3 & 0,0 & 91,8 \\
1908 & 4,2 & 40,1 & 46,2 & 0,0 & 90,5
\end{tabular}

\footnotetext{
${ }^{15}$ No início do século XX, o Departamento Antitruste da Secretaria da Justiça dos Estados Unidos obteve diversas vitórias judiciais contra os grupos industriais de Andrew Carnegie (aço), John D. Rockefeller (petróleo) e a Família Vanderbilt (transportes), dentre outros, desmontando monopólios e estabelecendo controle sobre trustes nas áreas mais lucrativas.
} 


\begin{tabular}{llllll}
1909 & 3,3 & 40,2 & 48,0 & 0,0 & 91,5 \\
1910 & 3,8 & 36,2 & 51,1 & 0,0 & 91,2 \\
1911 & 3,9 & 35,6 & 49,1 & 0,0 & 88,7 \\
1912 & 3,9 & 39,1 & 46,2 & 0,0 & 89,2 \\
1913 & 4,7 & 32,2 & 50,6 & 0,0 & 87,6 \\
1914 & 4,8 & 40,6 & 43,5 & 0,0 & 88,9 \\
\hline
\end{tabular}

FONTE - Estatísticas históricas do Brasil: séries econômicas, demográficas e sociais de 1550 a 1988 . $2^{\mathrm{a}}$ ed. rev. e atualizada, do v. 3 de Séries estatísticas retrospectivas. Rio de Janeiro, 1990.

A restrição ao consumo externo e os descontos nos preços internacionais do café e da borracha determinaram, além da queda na aquisição de metal, a redução na formação de renda no Brasil, levando a crise aos bancos e, desta forma, ao crédito e ao comércio. Negócios foram sendo paralisados e a falta de confiança se disseminou para os principais setores da economia. ${ }^{16}$ Como as importações dependiam dos meios de pagamento gerados pelas exportações, o primeiro semestre de 1913 ainda permitiu ao governo obter renda aduaneira com alguma normalidade, mas ao longo do segundo semestre a crise também chega às alfândegas e os recursos em papel diminuíram acentuamente, privando o setor público de parte fundamental de suas receitas. ${ }^{17}$

A expressiva falta de receitas públicas ampliou a suspensão dos pagamentos que o governo já praticava no comércio e o problema ganhou magnitude, resultando em perplexidade dos agentes econômicos que questionavam como uma guerra que parecia pequena e insignificante, mais uma dentre tantas no oriente, podia trazer tantos dissabores. Claro está que os canais de contágio da economia brasileira que fizeram com que a crise gerada na Europa a partir das guerras balcânicas provocasse este grau tão elevado de dificuldades foram os orçamentos deficitários em papel e em ouro, essencialmente o metal, o eixo sobre o qual estava estruturada a economia brasileira.

Para tentar obter ouro, Rivadávia Correa, ministro da Fazenda de agosto de 1913 até o final da presidência de Wenceslau Braz, buscou soluções que incluíam linhas de crédito internacionais para as exportações, mas principalmente por empréstimos nas principais praças financeiras da Europa. Quando se falava em Europa como fonte de financiamento de ouro para o Brasil, o assunto sempre acabava sendo finalizado em Londres, muito porque o

\footnotetext{
${ }^{16}$ Convocação de credores para concordata preventiva de negociantes de café. O Estado de S. Paulo, 21 dezembro1913, p. 16;

Concordata de importante negociante da praça de São Paulo, com interesses em várias casas comissárias, causou assombro no mercado. O Estado de S. Paulo, 29 dezembro1913, p. 11.

${ }^{17}$ Mensagem Presidencial - 1914, p. 6 e 7. Relatório da Fazenda - 1913, p. 43.
} 
histórico de atuação da Casa Rothschild desde os tempos do Império capacitava-os para estas operações, intensamente intrincadas, de consolidação e harmonização do passivo brasileiro. ${ }^{18}$ Os empréstimos aliviavam a carência de ouro, mas não na proporção dos valores concedidos porque grande parte era destinada ao pagamento de dívidas públicas e privadas com empresas de capital estrangeiro, passivos improdutivos que se arrastavam durante anos a fio até que um novo empréstimo sobreviesse e acalmasse os ânimos dos credores. Novos passivos significavam mais peso no serviço da dívida que já estava custando o equivalente a $20 \%$ das receitas um pouco antes da Guerra Mundial. ${ }^{19}$ Como o que restava para cobrir o orçamento era sempre insuficiente para atender o que os ingleses chamavam de "descalabro nas contas públicas", o governo dependia das entradas do ouro das importações para conseguir manter a economia funcionando. Quando ocorria alguma interrupção no fluxo de ouro para o Brasil a crise se instalava, fazendo o país sofrer desproporcionalmente com situações que deveriam ser encaradas como absolutamente normais, como as oscilações de preços no mercado internacional das commodities, como o café e a borracha. Qualquer decréscimo no preço da saca do café em Londres ou em Nova York (a partir de 1912), por exemplo, introduzia sempre um agudo elemento de incerteza na economia nacional, obstando a formação de capital, inibindo a diversificação nos negócios internacionais e uma paulatina moderação na dependência da demanda externa de produtos primários.

As críticas que o governo brasileiro recebeu de governos e de instituições financeiras europeias no decorrer do ano de 1913, quando a crise se mostrou mais aguda, residem nas diferenças como os problemas foram sentidos dos dois lados do Atlântico. Enquanto em Londres e em Berlim medidas de prevenção ajudavam a preservar o funcionamento básico das atividades da economia, como o vital acesso ao crédito, no Brasil a crise se instala de tal forma que é sentida pela sociedade como se o Reino da Bulgária fosse um país da América do Sul, e como se as fronteiras políticas na região estivessem se movendo, ameaçando interesses estratégicos brasileiros. O Império Alemão, por exemplo, totalmente envolvido com as complexas mudanças na correlação das novas forças que viriam a ter escala global, aplicou medidas de contingência que permitiram ao país atravessar a crise sem o comprometimento de elementos macroeconômicos indispensáveis, como o crédito. Havia até condições para que os

\footnotetext{
${ }^{18}$ N.M. Rothschild \& Sons, casa bancária que teve início em Frankfurt no final do século XVIII, se transferiu para Londres em 1809 e foi contratada pelo Império do Brasil como agente da dívida externa brasileira, posição de destaque na vida econômica do país que estes banqueiros ocuparam até 1930.

19 'The Financial Crisis of 1913', FO 371/1915/5814, 09 fevereiro 1914, p. 14.
} 
problemas econômicos de países como o Brasil fossem discutidos em Berlim, porque estas questões afetavam o capital alemão aplicado em áreas como a produção de insumos químicos, metais e comércio no território brasileiro. ${ }^{20}$

Londres ordenou o entesouramento, mas não deixou de contar com a estrutura montada no Rio de Janeiro, em São Paulo e em Manaus, principais praças de negócios para empresas britânicas, aparelhadas para fornecer relatórios sobre a política e a economia local com alto grau de detalhamento e sofisticação nas análises, que incluiam comparativos históricos e projeções. Proporcionalmente, estas atividades eram incompatíveis com a situação de delegação diplomática que os britânicos mantinham no Brasil e que tinha orçamento bastante limitado. ${ }^{21}$ Os ensaios que a Missão Britânica preparava sobre a economia brasileira eram regularmente depreciativos ao comparar como o Brasil estava se ocupando com a crise de 1913 e como se procedia em Londres, ou melhor, como eles, britânicos, haviam se preparado, dado que muitas críticas versavam sobre a inépcia da sociedade e do governo no Brasil em termos da capacidade em sequer vislumbrar a importância das contingências. A crítica mais frequente recaía sobre os subsequentes déficits públicos, em ouro e em papel, que não eram financiáveis nem em momentos cálidos do mercado financeiro internacinal e não o seriam naquele momento. As fortes mudanças trazidas pelos Bálcãs também alteraram a rotina econômica no Reino Unido, mas dentro de uma escala coadunável com momentos de incertezas em um mercado que contava com orçamentos públicos equacionados e sistema financeiro apropriado para o padrão de negócios que lá se desenvolvia. Isto era fundamental para poder continuar oferecendo o mínimo de condições para os negócios locais e internacionais das empresas britânicas. ${ }^{22}$

A crise advinda com as guerras balcânicas trouxe grave e dura reversão nas expectativas para o desenvolvimento econômico do Brasil. Foi o início de um clima de pessimismo que fazia crer que o país estava regredindo, reascendendo o debate sobre a volta da monarquia e os benefícios que um pouco de paz pudesse emanar a partir do poder central conduzido pelos Orleans e Bragança. A nostalgia do século XIX se instalou na elite brasileira. $\mathrm{Na}$ Europa, devido aos contatos de praxe entre as casas imperiais, acreditava-se seriamente que uma articulação entre os herdeiros do trono brasileiro e parte da elite nacional, com apoio

\footnotetext{
${ }^{20}$ Relatório do Deutsche Bank. O Estado de S. Paulo, 08 março 1913, p. 2.

${ }^{21}$ A Missão Diplomática Britânica no Rio de Janeiro somente se tornou Embaixada Britânica ao final da guerra, após negociações com o Governo Wenceslau Braz. 'Raising of Status of Mission at Rio de Janeiro' 11 novembro 1918, FO 371/3168/ 186628, p. 311.

22 'Financial Crisis in Brazil', 01 abril 1914, FO 371/1915/14347, p. 114.
} 
dos governos monárquicos europeus, poderia implantar no Brasil uma versão do sistema no qual a coroa passasse a responder ao parlamento. ${ }^{23}$

Como economia e política se confundiam muito fácil e rapidamente no Brasil, como sempre afirmavam os banqueiros britânicos que comparavam o país a outros mercados onde também tinham interesses, os agentes econômicos que há muito enriqueciam em um ciclo positivo de investimentos nos setores tradicionais de produção agrícola e no comércio urbano, começaram a pedir mudanças na atuação do governo, porque a forte retração de capitais que levou ao travamento das operações em um espaço de tempo muito curto parecia que não era apenas uma crise, mas o fim dos bons tempos econômicos. ${ }^{24}$

Transações comerciais financeiras que eram bem recebidas pelos bancos passaram a ser vistas como de risco elevado, espalhando o pessimismo para a economia como um todo. $\mathrm{O}$ governo, admitindo a extensão da crise, emitia análises por meio de relatórios e declarações que colocavam a culpa da situação em dois grandes equívocos, em duas dimensões de tempo: no passado, atribuindo a culpa às obras de infraestrutura que governos anteriores autorizaram, mas que cabia à administração atual obter recursos para os elevados desembolsos que não seriam financiáveis nem em momentos de crescimento econômico, muito menos agora, quando a redução nas receitas aduaneiras comprometia até mesmo o pagamento do custeio do setor público; e no futuro, justamente neste ponto, o da dependência do financiamento do setor público do imposto de importação e a necessidade de que fosse firmado um pacto nacional, governo e sociedade, para que a ilusão de bonança financeira que excelentes negociações de café ou de borracha no mercado internacional fosse trocada pela diversificação na produção e nos negócios, eliminando as amarras que ligavam praticamente toda a economia brasileira ao café e, em menor grau, à borracha. ${ }^{25}$

Sinal de que este futuro idealizado de diversificação nos negócios era uma alternativa difícil pode ser encontrado nas tentativas, malsucedidas, em criar para a borracha um aparato que viabilizasse a estruturação de truste similar ao que havia na época para o café. Depois da crise de 1907-8, a confiança do mercado interno no Comitê de Valorização do Café voltou

\footnotetext{
${ }^{23}$ John Gordon, investidor britânico com livre trânsito nos meios diplomáticos deixou registrado na chancelaria britânica: "Devido ao verdadeiro clima de caos que a crise financeira instalou, não que já não houvesse problemas, mas se você me perguntasse há dez anos se havia alguma chance de retorno da monarquia, eu diria que não. Agora, minha resposta é provavelmente". Para esta e outras passagens sobre o sentimento imperialista no Brasil, ver Imperialist Feeling in Brazil, 18 fevereiro 1913, FO 371/1580/7712, p. 41.

24 'British Legation', 30 agosto1913, FO 128/371, p. 94

${ }^{25}$ Relatório dos Negócios da Fazenda - 1914, p. 3.
} 
como que ungida pelo teste que o programa que previa controle da produção, dos estoques e do câmbio enfrentou e saiu praticamente ileso. Os empresários estavam satisfeitos com a forma pela qual a cafeicultura interagia com a economia como um todo, o que levou o Comendador Alexandre Siciliano a propor a criação de um truste para a borracha que funcionaria nos mesmos moldes do truste do café. Estas ideias não deram frutos porque a produção do látex foi introduzida no sudeste asiático com mais vantagens que no Brasil, tirando as condições de controle do mercado que um futuro Plano de Valorização da Borracha exigiria. A crise de 1913, dizia Siciliano, não era tão sombria e a base para este otimismo estava alicerçada na comercialização da safra de café naquele ano, com expectativa de obtenção de cinquenta mil contos de réis, valor bastante expressivo para o total de circulação de moeda no país. Dizia Siciliano que o maior problema que a crise evidenciava, além da borracha, era mesmo o excesso de importações de máquinas elétricas, de trilhos, de bens de capital e de bens de consumo que comprometeriam o futuro do país porque exigiriam recursos em ouro que o país não teria condições de amealhar. ${ }^{26}$

A crise econômica no Brasil em 1913 foi ampliada pela falta de controle do governo sobre os gastos públicos porque, afirmava a diplomacia britânica, o governo não sabia quais eram as reais despesas públicas, quanto e onde o dinheiro estava sendo usado ou para onde estava sendo drenado, na análise sem meias palavras da diplomacia britânica que dizia que o Brasil se comportava como um grande Haiti de tão desorganizado e mal administrado. ${ }^{27}$

Não havia confiança sobre as estatísticas em geral, admitia o próprio Ministério da Fazenda, e trabalhava-se sempre às cegas, com revisões constantes dos dados e com comparações com exercícios anteriores com números que também não eram confiáveis. Muito disto era devido à descentralização na coleta das informações que deixava a União na dependência dos governos locais que, por sua vez, seguiam regras estatísticas difusas. Neste contexto, medidas de contingência, de prevenção, como pedia Londres, tornavam-se difíceis. $^{28}$

A visão de fora da economia brasileira era igualmente crítica. O Reino Unido, por exemplo, registrava, por intermédio da chancelaria no Rio de Janeiro, o quão despreparado

\footnotetext{
${ }^{26}$ O Estado de S. Paulo, 27 dezembro1913, p. 8.

${ }^{27} \mathrm{O}$ modo como o governo brasileiro tratava questões diplomáticas, como a indicação do embaixador Oliveira Lima para Londres, era visto como extremamente desorganizado, sem critério, sem foco, fazendo o Brasil ser considerado nos meios diplomáticos como uma espécie de Haiti em grande escala. 'Brazilian Foreign Office Methods', 19 maio 1913, FO 371/1580 /22786. p. 20.

28 'Brazil-Annual Report, 1913. I - General Remarks', 09 fevereiro 1914, FO 371/1915/5814.
} 
estava o Brasil para enfrentar qualquer tipo de cenário econômico que não fosse o de superávit comercial e acesso fácil ao crédito internacional, endividando o futuro do país. No final de 1913 a crise ficou ainda mais aguda no Brasil. A diplomacia britânica dizia que os problemas eram alimentados por um grau de corrupção e gastos sem lógica alguma para um país tão necessitado de recursos externos. Dado o momento de restrição financeira na Europa, os britânicos sempre esperavam sinais de que o governo fosse colocar um freio nas extravagâncias para que pedidos de socorro pudessem ser levados às altas instâncias do tesouro. O que mais irritação provocava na diplomacia britânica era registrar que após um pedido de socorro financeiro em Londres, o Ministério da Fazenda do Brasil aprovava a liberação de verbas para gastos que não podiam ser realizados por um país em crise financeira, como aumentos salariais, repasses para governos estaduais realizarem eventos festivos ou mesmo para ajudar empresários em crise. O remédio que Londres pedia era o Brasil conter os orçamentos deficitários e isto exigia colocar nos projetos orçamentários os números da economia. ${ }^{29}$

A falta de um banco central no Brasil era sintomática da carência de estrutura para a prática de prevenção de crises. Quando o Banco da Inglaterra aumentou suas taxas de juros ao final de 1912 como reação à guerra nos Bálcãs, o governo brasileiro ficou ciente que os empréstimos no exterior ficariam mais difíceis, mas não houve movimentos anticíclicos concretos internos. Esta sinalização de Londres se concretizou com a redução dos preços do café e da borracha, levando o país a passar pelo primeiro déficit na balança comercial desde 1885-6, ao final do Império, como se pode observar na Tabela 1.4.

Tabela 1.4 - Balança Comercial, Brasil, 1911- 1915 (libra esterlina, mil)

\begin{tabular}{r|r|r|r|r}
\hline \multicolumn{5}{|c}{ IMPORTAÇÃO EXPORTAÇÃO TOTAL } \\
\hline 1911 & 52.822 & 66.839 & 119.661 & 14.017 \\
1912 & 63.425 & 74.649 & 138.074 & 11.224 \\
1913 & 67.166 & 65.451 & 132.617 & -1.715 \\
1914 & 35.473 & 46.803 & 82.276 & 11.330 \\
1915 & 30.088 & 53.951 & 84.039 & 23.863 \\
\hline
\end{tabular}

FONTE — Fonte: Repertório Estatístico do Brasil - Quadros - Retrospectivos, ano V - 1939-1940, Rio de Janeiro: Serviço Gráfico do Instituto Brasileiro de Geografia e Estatística,1941.

Os governos brasileiros estavam habituados a déficits orçamentários, mas não à situação de importações superando o valor das exportações, o que contribuiu em grande medida para o desespero que se instalou no mercado e para a incorporação da situação de

${ }^{29}$ Ibidem. 
crise nos pronunciamentos oficiais. ${ }^{30}$ A crise de 1913 se fez sentir nas exportações no mesmo ano, mas, nas importações o impacto da crise ficou registrado em 1914, com redução à metade dos valores importados, como indica a Tabela 1.4. Há que ser considerado que no segundo semestre deste ano, com a irrupção da guerra, os problemas que seriam ampliados por conta do bloqueio no transporte marítimo internacional que represou a demanda nos pontos de origem e de destino, causando elevada redução nos valores importados assinalados, independente das regras normais de mercado.

O certo era que a renda no Brasil diminuiria porque restrições ao crédito em Londres reduziriam o consumo no mercado internacional e os produtos exportados pelo Brasil teriam os preços depreciados levando à redução na renda dos exportadores brasileiros. Como o Brasil estava no padrão ouro, a falta de metal era catastrófica, paralisante de todas as atividades. A redução nas exportações de café comprometia todo o sistema porque o financiamento do orçamento em moeda não conversível também era dependente do setor externo e crises nos centros consumidores de produtos primários brasileiros se transformavam em um quadro negativo.

Os superávits voltaram à economia brasileira em 1914 e, por este ponto de vista, a situação começou a melhorar durante o primeiro semestre de 1914, mas isto foi devido à violenta contração nas importações. Comerciantes britânicos e americanos identificaram na crise dos Bálcãs as dificuldades do governo brasileiro em levantar recursos no exterior e também junto aos bancos locais, a maioria de origem europeia. Isto levou a um calote junto ao comércio local o que levou um número elevado de empreendimentos à falência. ${ }^{31} \mathrm{Na}$ opinião da diplomacia francesa, a situação era tão grave que havia risco de guerra civil no Brasil. Isto porque Pinheiro Machado, senador pelo estado do Rio Grande do Sul, o “condestável”, grande avaliador do governo Hermes da Fonseca, entrou em sérios atritos com o governo do estado de São Paulo que criticava duramente a atual administração federal e estava colocando barreiras para a muito provável candidatura de Machado à presidência da República nas eleições de $1914 .^{32}$ No final, a falta de apoio político de São Paulo deu impulso à resistência que já havia na elite cafeeira ao político do Partido Republicano Conservador e o nome de

\footnotetext{
${ }^{30}$ Mensagem Presidencial - 1913, p. 6 e 7.

${ }^{31}$ Ver Albert, South America and the First World War: the impact of the war on Brazil, Argentina, Peru and Chile, p 38. O autor estima o calote em US\$ 16.000.000 somente para os comerciantes da praça do Rio de Janeiro em 1914.

32 'Brazil - Financial and Political Situation', 05 maio 1913, FO 371/1580/20620, p. 419.
} 
Wenceslau Braz, vice de Hermes da Fonseca, ganhou apoio suficiente inclusive do próprio Machado que o substituía com frequência na presidência do Senado para vencer as eleições.

Apesar de não ter havido a temida guerra civil como apregoava a diplomacia estrangeira, a situação macroeconômica brasileira antes da guerra era crítica e somente não se transformou em catástrofe porque as reduções nos valores em ouro obtido com as exportações brasileiras ao longo de 1913 evitaram uma maior pressão sobre o câmbio e a Caixa de Conversão logrou emitir moeda com lastro em metal. O acompanhamento dos depósitos e retiradas da Caixa mostra que a situação chegando a um impassse inédito desde que o Convênio de Taubaté conseguiu estabilizar o câmbio no Brasil: o complexo mecanismo que permitia o controle da valorização cambial, como desejava a cafeicultura, era inacreditavelmente ineficaz quando o câmbio se desvalorizava, cenário criado com a crise dos Bálcãs, o que acabou por dar cabo das emissões conversíveis da Caixa. ${ }^{33} \mathrm{O}$ aprofundamento da crise e o novo funding loan que sobrevieram poderiam ter sido evitados se a relação complexa que existia entre o comércio exterior e o financiamento público não tivesse sido fortemente abalada, impedindo o país de honrar compromissos externos, como analisado na próxima seção.

\section{Seção 1.2 - Aspectos do comércio exterior brasileiro}

Entre o início do século XX até a Primeira Guerra, a balança comercial brasileira foi superavitária, com exceção de 1913 que, como consequência da crise balcânica e da redução nos valores exportados de café e borracha, apresentou o primeiro déficit comercial do país desde 1886, ou seja, os governos republicanos ainda não tinham tido a experiência de administrar a economia brasileira sem poder contar com o saldo positivo em ouro da balança comercial, e este fato foi o epicentro de sérios problemas para a macroeconomia nacional às vésperas da guerra. Na Tabela 1.5 é possível verificar que 1908 e 1913 foram os únicos anos nos quais os valores totais das exportações foram inferiores aos anos respectivamente anteriores e, nos dois casos, o motivo central para as reduções foram crises financeiras internacionais. A diferença entre estas crises reside no fato de que a de 1908 não provocou déficit comercial e, por isto, foi mais branda, e na de 1913 não houve redução dos totais importados devido à grande euforia econômica mundial que vigia até o início deste ano e que também contaminava o comércio brasileiro. Os efeitos da crise de 1913 sobre as importações ocorreram em 1914, ano de início da GUERRA, quando os totais para as exportações e

\footnotetext{
${ }^{33}$ Calógeras, Formação Histórica do Brasil.
} 
importações foram muito inferiores aos anos anteriores, mesmo em relação a 1913, ano do auge da crise. O superávit de 1914 ajudou o país a enfrentar a redução na renda aduaneira, mas durante a guerra não seria mais possível contar com a combinação de superávit comercial elevado e renda aduaneira crescente e isto significou aumento da vulnerabilidade externa com prejuízo ao comércio importador. Apesar deste superávit no primeiro ano da guerra, o déficit de 1913 continuou presente porque indicou graves problemas com as exportações, problemas que não foram solucionados com o início da guerra, mas foi durante o conflito mundial que mudanças na economia forçaram o governo a modificar a forma pela qual o setor externo da economia brasileira era administrado.

Tabela 1.5 - Balança Comercial, Brasil, 1901 - 1914 (libra esterlina, mil).

\begin{tabular}{|c|c|c|c|}
\hline & $\begin{array}{c}\text { Exportações } \\
\text { (FOB) }\end{array}$ & $\begin{array}{l}\text { Importações } \\
\text { (CIF) }\end{array}$ & Saldo \\
\hline 1901 & 40.622 & 21.377 & 19.245 \\
\hline 1902 & 36.437 & 23.279 & 13.158 \\
\hline 1903 & 36.833 & 24.208 & 12.625 \\
\hline 1904 & 39.430 & 25.915 & 13.515 \\
\hline 1905 & 44.643 & 29.830 & 14.813 \\
\hline 1906 & 53.059 & 33.204 & 19.855 \\
\hline 1907 & 54.177 & 40.528 & 13.649 \\
\hline 1908 & 44.155 & 35.491 & 8.664 \\
\hline 1909 & 63.724 & 37.139 & 26.585 \\
\hline 1910 & 63.092 & 47.872 & 15.220 \\
\hline 1911 & 66.839 & 52.822 & 14.017 \\
\hline 1912 & 74.649 & 63.425 & 11.224 \\
\hline 1913 & 65.451 & 67.166 & -1.715 \\
\hline 1914 & 46.803 & 35.473 & 11.330 \\
\hline
\end{tabular}

FONTE - Séries Estatísticas Retrospectivas - Repertório Estatístico do Brasil Quadros Retrospectivos - Comércio Exterior do Brasil.

O alívio na questão balcânica não melhorou o cenário para o comércio exterior brasileiro. O superávit de 1914 dissimulou o grave problema pelo qual a economia brasileira passava que era a crise no comércio importador. A explicação para valores tão reduzidos de trocas comerciais em 1914 foi que até julho daquele ano o comércio exterior ainda não havia sido atingido pela movimentação política internacional que acabou resultando na guerra. Somente a partir de agosto é que a situação nas importações refletiu o fim das transações comerciais com importantes parceiros europeus, como o Império Alemão e o Império AustroHúngaro. Esta situação persistiu até 1918. 
Em retrospectiva, além da crise de 1913 e da guerra, a década de 1910 foi de muitas modificações no setor externo da economia brasileira, como a consolidação das relações comerciais com os Estados Unidos e o fim da força das exportações de borracha na pauta do Brasil. Tantos eventos importantes não alteraram a dependência da política econômica da necessidade de superávits na balança comercial. O problema era que, com a urbanização crescente e o consequente aumento na dependência das importações para o suprimento da demanda interna, obter saldos positivos na balança comercial se tornou tarefa cada vez mais complexa porque o país não podia mais contar com as exportações da borracha e o café não pode mais ser valorizado como na década anterior porque os Estados Unidos passaram a condenar em seu mercado o esquema de cartelização que a Comissão de Valorização do Café, fruto do Convênio de Taubaté, estava acostumada a praticar na Europa.

A análise da pauta de exportações brasileiras no período imediatamente anterior à guerra demonstra que os problemas econômicos já eram evidentes. A borracha e o café, os mais importantes, apresentavam queda expressiva nos valores exportados. $\mathrm{O}$ açúcar, que tanta importância teve para o Brasil durante o período imperial, foi perdendo espaço no mercado internacional para o açúcar de beterraba e, no início da década de 1910, como indicado na Tabela 1.6, era um dos menos influentes no rol de exportações brasileiras.

Tabela 1.6 - Principais produtos exportados, Brasil, 1912-3

(libra esterlina).

\begin{tabular}{l|r|r}
\hline \multicolumn{1}{l}{ Produto } & $1912 *$ & $1913^{*}$ \\
\hline Algodão & 669.321 & 1.648 .288 \\
Açúcar & 53.609 & 64.404 \\
Borracha & 13.293 .433 & 8.909 .624 \\
Cacau & 1.073 .371 & 1.189 .774 \\
Café & 35.747 .256 & 30.616 .599 \\
Couro & 1.713 .887 & 1.944 .692 \\
Tabaco & 1.352 .069 & 1.530 .302 \\
Mate & 1.597 .309 & 1.971 .291 \\
* janeiro-outubro. \\
\hline Fonte: 'Brazil- Annual Report, 1913', FO 371/1915/5814, p. 18.
\end{tabular}

A observação dos dados da Tabela 1.6 mostra como o café e a borracha eram importantes para as exportações antes da guerra. Foram os movimentos nos preços, na quantidade demanda e no destino final destes dois produtos que deram a eles papéis centrais na crise de 1913 e nos seus desdobramentos até julho de 1914. Estes produtos compunham a 
maior parte das vendas aos três principais parceiros comerciais do Brasil no intervalo de tempo que antecedeu à guerra, Reino Unido, Alemanha e Estados Unidos. Em termos de parceiro nas exportações de café, os Estados Unidos já eram, de longe, o mais importante mercado desde que a política do free breakfast table do final do século XIX, política que praticamente zerou a tarifa para a importação do café nos Estados Unidos com o objetivo de melhorar o padrão de alimentação da população, aumentou sensivelmente o consumo do produto. Em 1912, por exemplo, o mercado norte-americano ficou com $42 \%$ das exportações do café brasileiro, mudando aos poucos, mas de maneira radical, a forma pela qual o Brasil comercializava café no mundo. Neste mesmo ano, os Estados Unidos ainda adquiriram 39\% do algodão e $50 \%$ da borracha que o Brasil exportou, o que demonstra como foi se alterando durante a década de 1910 o eixo central do comércio internacional brasileiro. ${ }^{34}$ O Ministério da Fazenda do Brasil deu preferência tarifária para produtos norte-americanos como compensação pela tarifa zero para colocar café brasileiro nos Estados Unidos, fazendo Londres creditar esta aproximação entre os dois mercados às aspirações do Brasil em poder contar com apoio de Washington em eventuais questões de segurança internacional. $\mathrm{O}$ estreitamento das relações internacionais entre os dois países era motivo de grande preocupação entre diplomatas britânicos, italianos e franceses, pois poderia ser um prenúncio da diminuição do poder europeu no mundo. ${ }^{35}$ Este receio não era infundado. Em termos gerais, com os valores de todos os produtos exportados somados, as compras norteamericanas representaram entre 1909 e 1914 até mesmo mais do que as exportações para a Alemanha e Reino Unido somadas, como mostra a Tabela 1.7.

Tabela 1.7 - Intercâmbio comercial - Brasil e principais parceiros, 1909 - 1914 (libra esterlina).

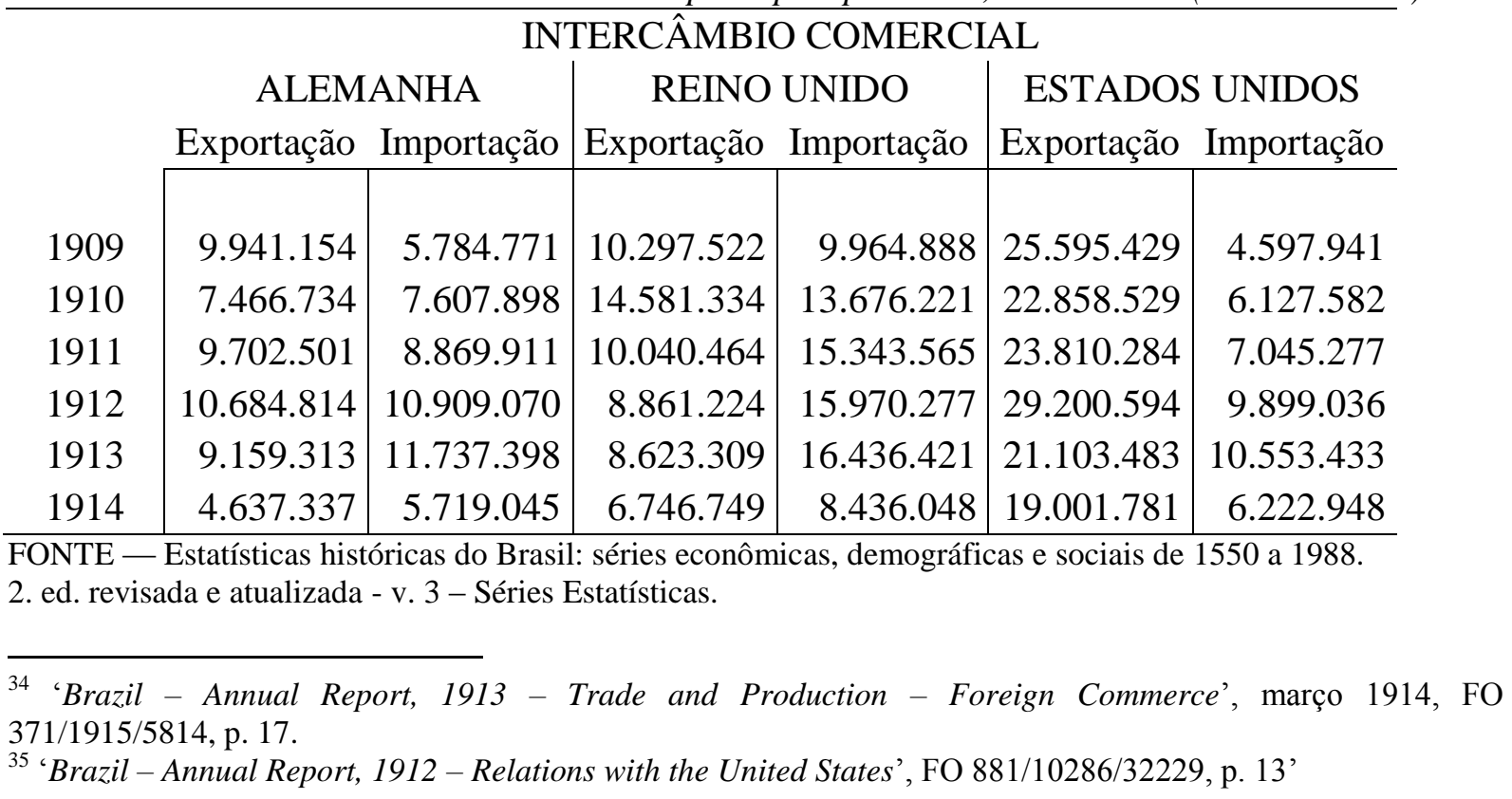


Em relação às importações de produtos americanos, observa-se que o movimento foi de ascensão a partir de 1909, mas, devido à guerra houve redução nos pedidos para o Brasil e também um claro redirecionamento dos interesses comerciais dos Estados Unidos para que lacunas de suprimentos na economia internacional deixadas pelos europeus fossem por eles ocupadas. Sobre a parceria com a Alemanha, nota-se na Tabela 1.6 que os valores importados do Brasil equivaliam às vendas aos britânicos e, em 1912 e 1913, período da crise, chegaram mesmo a ultrapassá-las, levando a crer que sem o advento da guerra Berlim se consolidaria como o segundo mercado mais importante para os produtos brasileiros. Quanto ao fornecimento de bens importados, produtos alemães ocupavam mais espaço na economia brasileira que os norte-americanos, mas ainda perdiam para os britânicos, muito por conta das relações financeiras que o Brasil tinha com Londres e que facilitavam o custeio de importações de produtos do Reino Unido. Estas relações comerciais eram, ao menos até o final da guerra, insufladas pelas relações financeiras com o Reino Unido que, ao viabilizar as importações do sistema ferroviário que se implantava no Brasil, permitiam ao governo brasileiro acesso à moeda forte. Até mesmo as exportações de café, pelo que se depreende da extensa documentação entre a Representação Britânica e o Ministério das Relações Exteriores em Londres entre 1906 e 1913, tiveram volume e valores induzidos no âmbito das relações financeiras entre os dois países, isto é, o mercado internacional para o café brasileiro recebia influência das relações internacionais que o Brasil mantinha com o Reino Unido e que transformava o produto em moeda de troca e pressão para os interesses britânicos e brasileiros na economia internacional. ${ }^{36}$

Apesar da força financeira do Reino Unido, os laços comerciais com os Estados Unidos se estreitaram a passos largos na década de 1910 e não foi por outra razão que a decisão da justiça norte-americana obrigando o Brasil a colocar um fim nos estoques estratégicos de café teve tanto impacto na economia brasileira em $1913 .{ }^{37}$ Esta medida dos Estados Unidos foi consequência da aplicação da Lei Sherman, medida antitruste aprovada no Congresso norte-americano em 1890 e que pairava como um grande prenúncio de sérios problemas para o principal produto de exportação do Brasil. Depois de muitas ameaças à Comissão de Valorização do Café, fruto do Convênio de Taubaté, a promotoria de Nova York conseguiu enquadrar o modelo de negociação do café brasileiro nos Estados Unidos como truste, acusação que obrigou o Brasil a aceitar negociar sem muitas opções e uma delas foi

\footnotetext{
${ }^{36}$ Como exemplo da influência de questões financeiras sobre o comércio exterior do Brasil, ver 'Loan of three millions Sterling to the State of San Paolo', 15 julho 1907, FO 371/201/23415, p. 316-318.

37 'Brazil - Annual Report, 1913', março1914, FO 371/1915/5814, p. 18.
} 
justamente a que resultou na venda dos estoques estratégicos em Nova York e, posteriormente, na Europa em $1913 .^{38}$ Esta medida, a venda dos estoques, teve impactos que foram muito além do previsto porque ocorreram em um momento de extrema fragilidade do setor externo da economia brasileira que já sofria com a crise da borracha e com a redução no fluxo de capitais. Esta alteração na regra do jogo para a comercialização do café brasileiro fez com que, muito antes da crise de 1929, os empresários do café já atinassem que a defesa dos preços do produto não teria vida longa.

Este clima de ameaças em 1913, repleto de negociações atípicas nos Estados Unidos, principal mercado para o café brasileiro, alimentou especulações de toda ordem e a tendência foi a queda no preço do produto. A superprodução estimada para o período 1914-1915, mais a produção de outros países concorrentes do Brasil, ultrapassaria o consumo mundial em aproximadamente três milhões de sacas, o equivalente a $10 \%$ da produção nacional, deixando um grande problema a ser solucionado pela Comissão de Valorização do Café. ${ }^{39} \mathrm{Na}$ verdade, apesar de todos estes percalços, não fosse a extrema necessidade de ouro para cobrir os compromissos externos da economia brasileira e, via renda aduaneira, os compromissos internos, a situação crítica do mercado cafeeiro seria mais um problema a ser administrado, mas não foi a causa que levou o Brasil a entrar em negociações para o segundo funding loan e que tantas mudanças trouxe para a economia nacional por muito longo tempo.

Além da questão do café, o fato novo, sobre o qual nem o governo nem o setor privado nada puderam fazer e que muita instabilidade interna alavancou foi a mudança abrupta no mercado internacional da borracha, um produto que não se compara ao café em termos de tradição nas exportações, mas que, pelo volume de recursos movimentado, muita dependência causou nas contas externas do Brasil. Esta dependência ganhou ares de tragédia quando a crise da borracha atingiu seu ponto máximo porque a economia brasileira ainda estava tentando contornar os problemas com os preços do café e com a falta de crédito internacional trazida pela crise de 1913. A somatória destes problemas mostra a real dimensão da situação calamitosa que experimentava a economia brasileira no limiar do segundo semestre de 1914, situação tão aguda que apenas uma mudança no status quo patrocinada por evento na economia internacional de consequências imponderáveis como a Primeira Guerra Mundial é que poderia indicar novos caminhos. Para entender de maneira mais acurada o cenário no qual

38 'Brazil - Annual Report, 1913 - Coffee', março 1914, F O 371/1915/ 5814. p. 19
39 'Brazil - Annual Report, 1913 - Rubber', março1914, FO 371/1915/5814, p. 20. 
se desenvolvia a economia brasileira neste período, é mister desvendar um pouco o papel da borracha, produto fundamental para indústrias da eletricidade e a indústria de motor à tração, grandes empreendimentos que muitas promessas garantiam a investidores em várias partes do mundo.

\section{Seção 1.3 - A crise da borracha}

O Brasil dominou de maneira absoluta o suprimento do mercado internacional da borracha do século XVIII até 1913 porque a Amazônia era o único local onde crescia de maneira natural e em grande quantidade a melhor fonte de látex, a seringueira (hevea brasiliensis). Durante o período republicano, as exportações brasileiras de borracha cresceram vigorosamente passando de $£ 2.788 .000$ em 1889 para $£ 24.646 .000$ em 1910 , mais de oito vezes o valor obtido no ano da Proclamação da República, como pode ser observado na Tabela 1.8. Esse resultado, por certo, ajudou em muito a manutenção da taxa cambial em patamar definido pela Caixa de Conversão (seção 2.2), mas, por outro lado, também permitiu ao governo continuar com a política econômica de extrema dependência do setor externo que tanta volatilidade causava nos negócios internos.

Tabela 1.8 - Exportações brasileiras de borracha, (libra esterlina, mil).

\begin{tabular}{l|c|c|r}
\hline \multicolumn{1}{c}{ ANO } & \multicolumn{1}{c}{ VALOR } & \multicolumn{1}{c}{ ANO } & \multicolumn{1}{c}{ VALOR } \\
\hline 1889 & $2.788,00$ & 1905 & $14.116,00$ \\
1890 & $2.550,00$ & 1906 & $14.056,00$ \\
1891 & $2.686,00$ & 1907 & $13.690,00$ \\
1892 & $3.012,00$ & 1908 & $11.785,00$ \\
1893 & $3.403,00$ & 1909 & $18.926,00$ \\
1894 & $3.554,00$ & 1910 & $24.646,00$ \\
1895 & $5.055,00$ & 1911 & $15.057,00$ \\
1896 & $3.774,00$ & 1912 & $16.095,00$ \\
1897 & $4.232,00$ & 1913 & $10.375,00$ \\
1898 & $5.325,00$ & 1914 & $7.063,00$ \\
1899 & $6.126,00$ & 1915 & $7.040,00$ \\
1900 & $6.499,00$ & 1916 & $7.496,00$ \\
1901 & $8.627,00$ & 1917 & $7.484,00$ \\
1902 & $7.294,00$ & 1918 & $3.998,00$ \\
1903 & $9.734,00$ & 1919 & $5.686,00$ \\
1904 & $11.220,00$ & 1920 & $2.742,00$ \\
\hline
\end{tabular}

Fonte: Fonte: Repertório Estatístico do Brasil - Quadros - Retrospectivos, ano V 1939-1940, Rio de Janeiro: Serviço Gráfico do Instituto Brasileiro de Geografia e Estatística,1941. 
O valor total de borracha exportado em 1910 foi atípico provocado não por aumento nas quantidades exportadas, mas sim pela escalada no preço no mercado internacional que chegou a atingir perto de $£ 1.000,00$ a tonelada, maior valor entre 1901 e 1935, patamar que não se sustentou, pois logo em 1911 já havia recuado para $£$ 600,00/ton. Apesar desta queda no valor da tonelagem, nada levava a crer no fim do ciclo da borracha no Brasil, mesmo porque o volume que o Brasil conseguia colocar no mercado internacional continuava dentro da média do início do século. A situação começou a mudar, preocupando o governo e o mercado, a partir de 1913 quando as exportações, devido à crise balcânica e ao aumento da oferta com a produção asiática, totalizaram $£ 10.375$ mil libras esterlinas, ou $35 \%$ abaixo do ano anterior. Para piorar este cenário de apreensão, os sinais no mercado indicavam que não haveria recuperação do nível anterior quando os valores totais giravam em torno de $£ 15.000$ mil libras, basicamente por conta da agressividade das empresas que comandavam a produção na Malásia e nos países daquela região que multiplicavam a produção global a cada ano.

Até 1913, os interesses estrangeiros na região do Norte do Brasil, que se transformou na principal fonte mundial da borracha, só aumentavam, fazendo com que empresas britânicas e francesas, principalmente, se instalassem em Manaus e em Belém. Essa situação alterava de maneira radical o mercado de trabalho local que foi forçado a utilizar novas técnicas de produção e de negócios trazidas por conglomerados empresariais como a Compagnie des Caoutchoucs e o Banque de Crédit Agricole et Hypothécaire que, no Pará, conseguiram impor regras de comercialização e de financiamento porque os valores envolvidos no comércio de látex eram proporcionalmente muito elevados em comparação às outras atividades econômicas locais. As decisões de negócios destas empresas acabavam por ter impacto direto na administração pública, estadual e federal, fazendo com que reivindicações privadas transformassem a pauta das relações internacionais dos países que eram sede dos capitais estrangeiros investidos na região Norte. As pretensões comerciais destas empresas francesas, por exemplo, se transformaram em espécie de ultimato supranacional do governo francês para que as autoridades brasileiras atendessem às solicitações. ${ }^{40}$

Em termos de mercado internacional, desde o início do século $\mathrm{XX}$ o maior problema para a borracha do Brasil já era a competição com os asiáticos que plantavam seringueiras em escala industrial, aumentando a produção em um ritmo próximo a 30\% ao ano. Apesar disto, o Brasil ainda conseguia atrair investimentos estrangeiros para o refino de borracha, como

\footnotetext{
40 'Extrait du message adresée le 7 septembre 1912 au Congrès legislatif du PARA par le Gouverneur Dr. João Antonio Luiz Coelho.', 27 janeiro 1913, FO 371/1580/3996, p. 51.
} 
ocorreu com a Goodyear que fechou contrato com o governo brasileiro para a instalação de fábrica no Rio de Janeiro com investimentos estimados em $£$ 650.000, valor considerado elevado, à época, para um empreendimento industrial. ${ }^{41}$ A intenção da Goodyear era se preparar para atender a demanda mundial que estava se elevando com a ampliação da participação do setor automobilístico no mercado da borracha, mas as consequências da crise de 1913 superaram as piores expectativas e a planta industrial prometida somente seria instalada em 1938, em São Paulo, para a fabricação de pneus e saltos de sapatos, momento no qual o Brasil já havia há muito deixado de ser um importante produtor neste mercado. ${ }^{42}$

Parte deste refluxo no investimento internacional teve relação com a queda no preço do produto no mercado internacional, o que levou um grande número de extrativistas a deixar o Brasil e tentar a sorte no Peru e na Bolívia, também produtores de látex, mas em escala muito inferior à brasileira. Era o elemento que faltava para o capital estrangeiro tirar o Brasil dos seus planos ainda antes da guerra.

Tudo aconteceu de maneira muito rápida. Entre 1912-3, o país ainda era o maior exportador mundial de borracha, mas a produção da Malásia, Ceilão (atual Sri Lanka) e Indonésia já ameaçava o predomínio brasileiro no mercado mundial. Estes países entraram neste mercado como resultado de parcerias estratégicas empreendidas pelos governos e empresas do Reino Unido, Países Baixos e França a partir do final do século XIX, principalmente. O objetivo era produzir látex nas colônias tropicais asiáticas destes países em escala industrial, multiplicando em curto espaço de tempo a oferta do produto para atender o aumento da demanda que se previa exponencial pelos setores de calçados, indústria de máquinas e automóveis, especialmente este último. A produção asiática surge, então, de maneira um tanto quanto repentina para os padrões de produção estruturados no Norte do Brasil e, logo em 1907, chega com força ao mercado, mas ainda era considerada apenas uma ameaça à produção brasileira. Entre 1912 e 1913, esta ameaça velada se transformou na mais pura e dura realidade quando o látex asiático ultrapassou a produção brasileira derretendo os preços no mercado internacional. Não havia o que fazer. A avalanche de problemas foi destruindo todas as esperanças em uma recuperação do mercado. Em 1915 a produção brasileira foi apenas metade da asiática. O Brasil nunca mais recuperou o posto de maior exportador do produto e, com a produção asiática crescendo de maneira exponencial, o Brasil

\footnotetext{
41 'Brazil-Annual Report, 1913’, FO 371/1915/5814, p. 22.

42 'Brazil - Annual Report, 1913 - Rubber', 371/1915/5814, p. 19.
} 
teve que se contentar com uma pequena fração do mercado a partir de então. Os preços elevados da borracha, que tantos investimentos atraíram para Belém e Manaus, começaram a cair a partir de 1911 ficando na faixa de $£ 200$ a $£$ 400/t entre 1913 e 1918, valor muito inferior ao ponto máximo de aproximadamente £ 1.000/t alcançado em 1910 quando a demanda pelo produto foi sensivelmente superior à oferta. ${ }^{43}$

Os preços da borracha brasileira, antes mesmo das mudanças radicais provocadas pela produção asiática, foram mais baixos que na década anterior. Um dos motivos foi a sazonalidade provocada pelas cheias dos rios da bacia amazônica, questão inexistente nas plantações asiáticas que podiam, assim, produzir o ano todo. A estes percalços insolúveis devem ser adicionadas as inovações tecnológicas aplicadas na produção de pneus que passaram a ter vida útil cada vez maior, contribuindo na redução dos preços pagos aos produtores de látex. $^{44}$

Como visto, entre o final do século XIX e o início da guerra, as exportações de borracha foram de extrema importância para o Brasil. É possível mesmo afirmar que o produto foi um elemento mais central que o café para a crise de 1913 e para o que ocorreria na economia brasileira até o início da guerra porque as exportações do produto, que já estavam contabilizadas nos orçamentos da União como entrada certa, declinaram de maneira irreversível durante a crise balcânica, reduzindo a entrada de cambiais, exatamente quando a economia brasileira mais precisava de ouro. A crise nos Bálcãs e a crise da borracha foram dois problemas no setor externo da economia brasileira sobre os quais nem o mercado e muito menos o governo sabiam que medidas deveriam ser tomadas. Apesar da redução nos preços do café também ter contribuído para os eventos negativos de 1913, o sistema que amparava a economia cafeeira era bastante preparado para os ciclos que a acometiam com frequência cada vez maior e, mesmo com a mudança nas regras de comercialização impostas pelo mercado norte-americano ao aplicarem a Lei Sherman, o Brasil encontrou mecanismos para continuar líder e price maker do produto em escala global. Não foi o que aconteceu com a participação brasileira no mercado da borracha.

O custo da borracha selvagem, tipo encontrado na região amazônica, exportado pelo Brasil, era sobrecarregado com tributação dos estados produtores deixando o produto nacional

\footnotetext{
${ }^{43}$ Para informações detalhadas sobre produção e preços da borracha no mercado internacional, ver 'The international natural rubber market, $1870-1930$ '. Zephyr Frank, Stanford University and Aldo Musacchio, Ibmec São Paulo. http://eh.net/encyclopedia/the-international-natural-rubber-market-1870-1930/

${ }^{44}$ Ibidem.
} 
cada vez menos competitivo conforme a produção da borracha plantada, asiática, bem menos onerada, chegava aos mercados consumidores. Para uma noção dos efeitos dos encargos sobre o produto, a borracha era alvo de muito contrabando para a Bolívia que de lá era exportada com o pagamento de tributação de $2 \%$ sobre o valor, alíquota expressivamente menor que no Brasil onde os estados produtores cobravam 18\%. Estimativas da Inspetoria da Alfândega de Manaus indicam que aproximadamente dois terços de toda a borracha exportada pela Bolívia tivesse tido origem brasileira, especialmente dos Estados do Amazonas, Acre e Mato Grosso. $^{45}$

Muitas tentativas foram feitas por negociadores britânicos e franceses buscando a redução destes tributos, mas eles sempre esbarravam na dependência que os estados da região Norte tinham desta receita. Além desta dependência, Pará e Amazonas usavam a borracha como forma de exigir mudanças na distribuição de recursos federais e apoio ao desenvolvimento local. Foram bem sucedidos, ao menos enquanto os preços do produto no mercado internacional permitiram atingir parcialmente os seus objetivos. ${ }^{46}$

A importância da borracha para o Brasil foi de tal ordem que o governo federal teve que intervir em estados onde políticos locais ameaçavam os interesses financeiros da União, como no Amazonas, contra o Coronel Bittencourt, e no Pará, contra Lauro Sodré. Nestes dois casos, Hermes da Fonseca utilizou a prerrogativa de poder nomear governadores para fazer acordos políticos, especialmente em postos lucrativos como o de governador do Pará. ${ }^{47}$ Ser chefe do executivo em um estado que movimentava milhões de libras esterlinas anualmente era motivo de cobiça para políticos de todo o Brasil porque poderiam fazer fortuna em pouco tempo, mesmo longe do relativo conforto da capital federal. Esta situação de eldorado na região Norte do país estava, contudo, com perspectivas cada vez menos otimistas à medida que chegavam ao mercado internacional as quantidades por demais elevadas da borracha do oriente. O governo brasileiro, preocupado com a invasão da borracha de origem estrangeira no mercado internacional, ofereceu prêmio de $£ 33.300$ para as primeiras fábricas que se instalassem nas cidades do Rio de Janeiro, Recife, Salvador, Belém e Manaus. ${ }^{48}$ O objetivo era fazer com que estes empreendimentos industriais mantivessem aquecida a demanda pelo

\footnotetext{
45 'Defesa da Borracha e Brasileira e a Repressão do Contrabando no Amazonas', Imprensa Oficial, Rio de Janeiro: 1924, p. 15.

46 'Brazil - Annual Report, 1913 - Rubber', março1914, FO 371/1915/5814, p. 20.

47 'Brazil - Annual Report, 1912 - Relations with the United States', setembro, 1913, FO 881/10286/32229, p.21.

48 'Brazil - Annual Report-Rubber', setembro 1913, FO 881/10286/32229, p. 36.
} 
látex brasileiro. Com este panorama do mercado da borracha somado às guerras balcânicas a situação de crise ganhou contornos muito sombrios. Somente um novo empréstimo e mudanças trazidas pela guerra resolveriam o problema, permitindo algum tipo de ação pública sobre a macroeconomia.

Os empresários ligados ao negócio da borracha ensaiaram alguma reação. Em uma das tentativas, a que mais repercussão e reações provocou foi a de se discutir a aplicação ao negócio da borracha do mesmo expediente de cartelização utilizado no café, algo como um 'Comitê de Valorização da Borracha'. O plano não se concretizou, mas em outubro de 1913, o jornal $O$ Estado do Pará passou a defender sugestões de políticos estaduais para a criação de um banco federal que pudesse regular os preços da borracha e que tivesse o monopólio de todo o látex da região amazônica. Neste mesmo ano, chegou-se a tentar um plano de valorização patrocinado pelo Banco do Brasil, mas o prejuízo de $£ 1.500 .000$ não permitiu vida longa ao projeto, ainda mais em um momento de negociações com os Rothschilds, justamente eles, tão enfaticamente contra qualquer plano de controle de preços no Brasil. ${ }^{49}$ Esta ideia só foi encampada pelo Banco do Brasil porque embutia a definição de um preçoalvo para o produto e que poderia evitar as flutuações nos preços que tantos problemas traziam para a economia local e para as finanças do Brasil devido à importância que a borracha conquistou no comércio exterior brasileiro a partir do início do século $\mathrm{XX}$. $\mathrm{O}$ Consulado Britânico em Belém não demorou em reagir com toda a ênfase possível, e passou a disparar alertas para que Londres se pronunciasse evitando o que seria desastroso aos interesses do capital britânico, não apenas no Brasil, mas na cadeia de remuneração que a borracha proporcionava em diversos negócios no mundo todo porque, na década de 1910, a utilização da borracha já estava disseminada em diversos segmentos industriais, como calçados, construção civil e na indústria automobilística. A produção de automóveis, por exemplo, apesar de incipiente, indicava lucros em escala geométrica e ampliava o mapa de atuação do capital internacional comprometido com a borracha.

O receio do governo britânico era que um banco como o que se aventava no Pará eliminasse parte importante da remuneração do capital que cabia às empresas produtoras estrangeiras. Na opinião do Ministério das Relações Exteriores do Reino Unido, em vez de tentar controlar o comércio da borracha, o Brasil deveria era acabar com as amarras que dificultavam a importação de máquinas e de gêneros de primeira necessidade para os campos

49 'Brazil - Financial and political situation: reports on gloomy outlook.' 05 maio 1913, 371/1580/20620, p. 417-422. 
de produção nos seringais, condição que tirava a fluidez que a saída da borracha do Brasil deveria ter para chegar com preço e condições mais adequadas no mercado internacional. $\mathrm{O}$ estabelecimento de um preço fixo para a borracha jamais poderia funcionar porque os salários dos seringueiros não poderiam jamais ser fixos posto que a demanda pelo produto era muito volátil ao longo do ano. A objeção levantada pelo Consulado Britânico foi o de que a borracha em um mercado absolutamente livre traria um lucro muito maior, situação ideal para uma distribuição mais equânime do poder dos entes federativos brasileiros, como há muito exigiam os governantes amazônicos, que se achavam desprestigiados na distribuição da riqueza nacional. Internamente, ou seja, em correspondência secreta com Londres, o cônsul britânico criticava a corrupção enraizada na sociedade e a incapacidade do Brasil em ser produtivo por conta própria, razão pela qual o Reino Unido deveria explorar, além da borracha, outras fontes de lucro, como polpa de madeira, óleos vegetais das diversas espécies de palmeiras, sorgo, amido de milho, forragem para animais, dentre outras possibilidades animadoras de lucro. A borracha era apenas um exemplo de como se podia ganhar muito dinheiro com comércio exterior no Brasil, bastando acionar os mecanismos corretos. ${ }^{50}$.

Conclusão.

As alterações na economia internacional provocadas pelas guerras balcânicas forçaram o Brasil a trabalhar em um cenário de escassez de divisas. Exportações tradicionais do país foram reduzidas. O mercado da borracha foi alterado com a concorrência os asiáticos. Foram feitas tentativas por parte do governo em reverter a situação, mas os resultados não compensaram as perdas. O café brasileiro buscou e encontrou mercado nos Estados Unidos, mas não foi possível estabelecer um sistema de controle de preços como o Brasil havia feito até então no mercado internacional.

O ano de 1913 foi de déficit na balança comercial brasileira, fato excepcionalmente raro naquele período da história econômica brasileira. Importações elevadas significaram arrecadação aduaneira maior, mas o ciclo dos negócios internacionais já indicava que a economia do país passaria por muitos problemas no ano seguinte.

50 'Commercial crisis - British Vice-Consulate, Manaos', 27 setembro1913, FO 128/371, pasta "Pará Consulate". 
As relações do Brasil com o sistema financeiro internacional foram influenciadas pelo distanciamento entre o Império Britânico e o Império Alemão durante as guerras balcânicas. Não foi mais possível a economia brasileira obter recursos na praça de Londres da maneira que o país estava habituado. A Europa estava passando por um momento de contingenciamento porque os desentendimentos entre o Reino Unido e a Alemanha indicaram que os conflitos nos Bálcãs tiveram força suficiente para contagiar todo o continente. O ouro que o Brasil tanto necessitava ficou entesourado na Europa. Esta carência de divisas forçou mudanças na política econômica brasileira porque foi necessário encontrar soluções para o financiamento do orçamento. Como as contas públicas do Brasil dependiam em larga medida dos tributos aduaneiros, o câmbio era fator de suma importância. A relação entre financiamento interno, importações e câmbio são temas do próximo capítulo. 


\section{Capítulo 2 - Impactos da crise internacional no financiamento interno brasileiro}

As importações brasileiras cresciam de maneira regular desde o início do século XX. Graças à entrada de recursos provenientes das exportações de café do período anterior, o Brasil pode importar em 1913 valores tão elevados que a balança comercial apresentou déficit. $\mathrm{O}$ ciclo de exportações fornecendo divisas para as importações havia atingido o ponto máximo antes da Primeira Guerra Mundial.

Os gastos públicos eram totalmente dependentes dos tributos aduaneiros. Estes tributos geravam receitas em papel e em ouro. O problema que a crise de 1913 provocou na economia brasileira foi que o país teve reduzida a sua capacidade de importação. Isto significava que o orçamento em ouro não poderia mais ser financiado e que medidas paliativas teriam que ser encontradas.

Para substituir a arrecadação em papel do imposto de importação, o governo alterou a cobrança do imposto sobre o consumo. Este era o único tributo que poderia atender em parte a necessidade de recursos públicos. O governo tentou também arrecadar mais com o imposto sobre a renda, mas as dificuldades para estabelecer este tributo na sociedade brasileira não permitiram que a arrecadação fosse significativa. Para substituir a arrecadação em ouro, o governo aumentou a cobrança da quota-ouro, como era chamado o imposto de importação que deveria ser pago em moeda conversível. Este aumento na quota-ouro não foi suficiente para atender a demanda e ainda provocou muita reclamação da sociedade, especialmente do comércio importador que era o mais importante no Brasil.

A redução nas exportações e as consequências sobre as importações reduziram o acesso à moeda conversível. Os impactos sobre o câmbio foram expressivos, causando muita oscilação na cotação da libra inglesa. A Caixa de Conversão não suportou este cenário de carência de ouro e encerrou as emissões de notas conversíveis. Enquanto a entrada de divisas superou a saída, a Caixa cumpriu o seu papel de estabilizadora do câmbio, mas quando a situação se inverteu, os depósitos em ouro na instituição foram reduzidos em curto espaço de tempo. O Brasil estava fora do padrão-ouro. Como executar a política econômica nestas condições é o que será visto neste capítulo. 


\section{Seção 2.1 - Aspectos gerais das importações}

As importações realizadas pelo Brasil apresentaram valores crescentes do início do século XX até 1913, quando o valor total apurado foi $214 \%$ acima do verificado em 1901. A participação dos produtos importados para o suprimento do mercado nacional era elevada, especialmente no comércio que necessitava de algodão, produtos químicos, cobre, aço e papel, cujos valores somados significaram perto de $50 \%$ do total geral. A alimentação também dependia em grande medida do exterior e ocupou algo como $20 \%$ do total trazido do exterior, percentual elevado se for considerado que eram produtos de valor baixo, como farinha de trigo, cevada e manteiga. Até mesmo a indústria, apesar de incipiente, utilizou outros $20 \%$ do total das importações para adquirir muitos produtos intermediários, como fios para tecelagem e pasta de papel, situação de dependência do exterior que provocava discussões sobre a viabilidade de o país utilizar o ouro, de tão difícil aquisição, para abastecer um setor classificado como artificial por não conseguir sobreviver sem insumos importados. ${ }^{51}$

As importações realizadas em 1913 foram tão volumosas e abasteceram o comércio de tal forma que reduções nos volumes importados no ano posterior devido à crise não se fizeram sentir nos meses que antecederam a guerra. A crise provocada pelos conflitos nos Bálcãs causou efeito duplo ao restringir o crédito no mercado internacional, deixando o negócio importador estabelecido no Brasil muito mais difícil e também reduzindo os pedidos de compras, redundando em queda drástica nos pedidos junto aos fornecedores estrangeiros. A questão que se coloca é que este superávit foi devido à redução nos valores importados mais do que ao aumento nos valores exportados. Como o mercado interno brasileiro dependia muito dos artigos importados, reduções nas importações não poderia ser sinal positivo para a atividade econômica do país.

O ponto mais elevado da série histórica brasileira do comércio de importação ocorreu justamente em 1913, quando foram computados um pouco mais de 67 milhões de libras esterlinas, montante somente possível devido aos estímulos do crédito inflacionado, dos preços relativamente altos do café e da euforia que dominava o comércio no Brasil e no mundo até o acirramento das guerras balcânicas. Com o advento da crise, os importadores foram duplamente prejudicados porque não podiam mais contar com a abundância de recursos externos na forma de crédito e financiamento e porque, internamente, estes comerciantes

\footnotetext{
${ }^{51}$ Séries Estatísticas Retrospectivas - Repertório Estatístico do Brasil - Quadros Retrospectivos - Comércio Exterior do Brasil.
} 
estavam com receitas imobilizadas em créditos do Governo, dívida pública com prazo vencido há dois anos ou mais. Desta forma, mesmo com o alívio obtido com o arrefecimento da crise balcânica, a situação dos importadores continuava péssima porque não havia sinal para a recuperação dos valores retidos junto ao poder público, passivo estimado em 20 milhões de libras esterlinas que o Ministério da Fazenda dificilmente teria condições de honrar dado o cenário de arrecadação da renda aduaneira que estava muito abaixo do previsto em face da redução nas quantidades e valores importados. ${ }^{52}$

Em 1913-4, a dependência do governo do imposto de importação em ouro ficou próxima a $90 \%$ e em papel a 50\%. O complemento da arrecadação não obtido com a renda aduaneira em ouro veio com a tributação sobre a encampação de estradas de ferro e, em papel, com o imposto sobre o consumo, rendas especiais e imposto sobre a renda, nesta ordem. A crise de 1913 somente se fez sentir na arrecadação do imposto sobre produtos importados em 1914 porque no ano anterior os valores importados foram muito elevados. Isto quer dizer que este ano do início da guerra, além de refletir a retração no consumo de importados, também foi o ano que registrou diminuição na arrecadação dado que, entre outros motivos, o transporte internacional de navios mercantes foi totalmente modificado, e passou a ser proibido para diversos tipos de produto e destino, como abordado no capítulo 2 . O impacto da crise nas receitas públicas pode ser notado na Tabela 2.1. O ano de 1913 não registrou alterações significativas entre os totais orçados e arrecadados, ao contrário do que se passou no ano seguinte, quando a arrecadação do principal tributo da União foi reduzida entre $40 \%$ e $50 \%$ frente aos valores orçados.

Tabela 2.1 - Receitas da União, orçamento e arrecadação, 1913-4 (contos de réis).

\begin{tabular}{|c|c|c|c|c|c|c|}
\hline & \multicolumn{3}{|c|}{ Imposto de importação } & \multicolumn{3}{|c|}{ Imposto de importação } \\
\hline & Ouro & & & papel & & \\
\hline & orçamento & arrecadação & Dif. (\%) & orçamento & arrecadação & Dif. (\%) \\
\hline 1913 & 102.601 & 99.469 & $-3,1 \%$ & 178.595 & 176.025 & $-1,4 \%$ \\
\hline 1914 & 99.780 & 52.930 & $-47,0 \%$ & 172.365 & 97.618 & $-43,4 \%$ \\
\hline
\end{tabular}

Fonte: Ministério da Agricultura, Indústria e Comércio. Diretoria Geral de Estatística. Estatística das Finanças do Brasil - Receitas, despesas e dívidas públicas da União, Estados e Municípios. Rio de Janeiro, 1926.

\footnotetext{
${ }^{52}$ FRITSCH, Winston. Aspectos da política econômica no Brasil, 1906-1914. In: Economia brasileira: uma visão histórica / coordenador: Paulo Neuhaus. Rio de Janeiro: Campus, 1980, p. 291-5.
} 
A escassez de recursos não dava espaço para outras considerações que não a necessidade sempre premente de diminuir o déficit público. Foi por este motivo que o governo não pode aproveitar uma discussão bastante recorrente na primeira década republicana para mudar a dependência das finanças públicas para um tributo considerado como ideal, isto é, o menos nocivo ao sistema econômico, qualidade do imposto de renda. $\mathrm{O}$ tributo, conhecido na época principalmente pelo nome em inglês, income tax, vinha de experiência bem sucedida na Inglaterra e a noção de que um governo deveria depender essencialmente de impostos diretos e neutros se espalhava pelo mundo.53

Os problemas na arrecadação do imposto de importação levantaram muita discussão sobre a dependência do país deste tributo. O imposto sobre o consumo, antes mesmo de o tributo ter se transformado em um dos salvadores das finanças públicas durante a guerra, ganhou atenção por outro motivo: a falta de confiabilidade nos dados econômicos e financeiros. A ideia era alçar o tributo como fonte de receitas indispensável, mas também empregá-lo como instrumento para melhorar o grau de informação sobre a economia brasileira por meio da estatística, pois a falta de informações para a elaboração dos orçamentos era constantemente citada como um dos graves problemas da administração pública daquele período.

Em matérias na imprensa, como a intitulada "A utilidade do imposto de consumo", o tributo, também conhecido à época como "imposto Murtinho", teria sido excelente para evitar estimativas equivocadas em um país onde tudo se media "a olho", como se dizia então sobre a falta de precisão que dominava a economia brasileira, e serviria para identificar de maneira exata o desenvolvimento do comércio por meio do consumo. ${ }^{54}$ Relatórios para Londres eram enviados com apenas parte dos dados oficiais porque o atraso na publicação era grande. Em 1913, por exemplo, o governo federal publicou os dados consolidados de $1907 .{ }^{55}$ Para fazer frente à falta de informações, técnicos especialistas da Delegação Britânica no Rio de Janeiro se municiavam de dados do mercado como associações de classe, bancos e registros de empresas na Junta Comercial para montar relatórios de maneira mais rápida, mas que não perdiam em qualidade por utilizarem as mesmas fontes do governo federal, só que em prazo muito menor. O problema parecia ser a limitação de alcance do tributo. Em 1913, a arrecadação do imposto sobre o consumo se deu principalmente sobre tecidos, fósforos,

\footnotetext{
53 O Estado de S. Paulo, 24 julho 1913, p.4.

${ }^{54}$ O Imparcial, 27 abril 1913, p.5

55 'Brazil - Annual Report, 1912 - Finance. Revenue and Expenditure', setembro 1913, FO 881 / 10286 / 32229 , p.30.
} 
bebidas, fumo e vinho estrangeiro, mas a arrecadação junto aos comerciantes era tarefa que exigia força insólita. O fumo, por exemplo, foi objeto de uma verdadeira luta do governo contra a sonegação, levando mesmo a uma ingerência pública na apuração do lucro dos fabricantes de tabaco, tudo com o propósito de assegurar uma receita que passou a ser importante demais, por isto a fiscalização extraordinária.

Como os tributos sobre consumo e sobre renda ainda estavam muito distantes de conseguir atender a necessidade urgente, imediata, por cada vez mais recursos, o governo brasileiro foi compelido a proceder a revisões para cima nas tarifas de importação provocando, logicamente, arrebatamento nos exportadores de países com maior influência no Brasil, caso da França, Alemanha e Reino Unido. Em alguns momentos, a pressão para que o Ministério da Fazenda diminuísse os custos da importação era tão explícita que alterações nas alíquotas, por exemplo, eram feitas de acordo com a demanda vinda diretamente dos comerciantes interessados, exportadores no Reino Unido e importadores no Brasil, como a que aconteceu em agosto de 1913. Como estas modificações ficaram aquém das expectativas dos empresários britânicos, e como Londres subiu o tom nas discussões, uma espécie de compensação foi encontrada: a taxa cambial tributária utilizada para a cobrança do imposto sobre consumo de importados passou a ser feita por 16 d. e não mais por 12 d., redução de 25\%. Além disto, Londres obteve redução no imposto em ouro, cobrado na base de $40 \%$ do total do imposto de importação, que passou a ser calculado pela taxa de $27 \mathrm{~d}$. e em vez de 16 d., algo como $40 \%$ menor. $^{56}$

Estas reduções na tributação sobre importados eram muito pontuais e nada perenes. Passado algum tempo, às vezes semanas, as cobranças voltavam a ser praticadas com as alíquotas e taxas de câmbio anteriores às mudanças porque, alegava o governo, emergências orçamentárias assim exigiam. Na verdade, como o mercado tinha ciência, e isto incluía inclusive os exportadores estrangeiros, as reduções nos tributos eram meros artifícios para diminuir as reclamações dos agentes econômicos mais organizados, e a tendência seria sempre a de onerar cada vez mais o setor de importação e, consequentemente, encarecer o custo de vida. A crescente carga tributária brasileira era duramente criticada em âmbito internacional, mas, na falta de uma agência multilateral, os países com economias mais poderosas pressionavam o Brasil com todos os meios diplomáticos e financeiros de que dispunham com o intuito de permitir que o comércio exterior fluísse de maneira mais livre.

\footnotetext{
56 'Brazil - Annual Report, 1913 - Tariff Revision'-FO 371/1915/5814, p. 22.
} 
Estudos realizados pelo governo britânico indicaram que a média do imposto de importação cobrado no Brasil era ao menos o dobro da média cobrada nos principais mercados mundiais e que as recentes tentativas em impulsionar a produção manufatureira nacional por meio da proteção tarifária era a grande responsável pelo alto custo de vida que se instalou no país. ${ }^{57}$ $\mathrm{Na}$ verdade, os britânicos sabiam que não era para proteger empreendimentos fabris nacionais que o imposto sobre consumo de importados aumentava com espantosa regularidade, mas sim para atender a incontrolável necessidade de financiamento em ouro e em papel que o governo brasileiro, além dos empréstimos, conseguia com as tarifas aduaneiras. Era um caminho sinuoso que o governo brasileiro utilizava para se financiar internamente utilizando um tributo que deveria ser aplicado para o fomento da produção nacional.

O governo britânico demonstrou por meio de documentação farta que o Brasil conseguiria muito mais recursos para gerar empregos e melhorar a qualidade de vida da população se permitisse taxas mais baixas do imposto aduaneiro, de tal ordem que o comércio exterior fosse menos sobrecarregado e que a população tivesse acesso a artigos melhores e mais baratos, mas isto somente ocorreria se a roda das importações girasse em velocidade cada vez maior.

Apesar de alguns registros de empresários brasileiros que reclamavam da indústria artificial, o povo brasileiro parecia, nos relatos da representação britânica, extremamente cordato e resignado com a situação de carestia que o governo impingia. Secretamente, falando com Londres, a delegação no Rio de Janeiro dizia que o povo brasileiro era inerte porque não tinha visão de mundo e vivia de maneira sórdida. Até mesmo os mais abastados viviam com um grau de conforto tão baixo, de padrão tão rudimentar que nem as famílias humildes da Inglaterra aceitariam. No Brasil, afirmavam os diplomatas britânicos, o custo de vida era, no mínimo, três vezes superior ao da Europa, mas o povo não se importava. Quem parecia realmente sofrer esta situação vexaminosa eram justamente os trabalhadores estrangeiros que procuravam o Brasil como terra de oportunidades, atraídos que eram por possibilidades de salários enganosamente elevados, salários que não permitiam dignidade de vida. ${ }^{58}$

Como forma de confrontar as justificativas do governo brasileiro para a prática de taxas de importação elevadas, foram levantados diversos dados: segunda a chancelaria britânica havia no Brasil, 3.664 estabelecimentos industriais com capital totalizando $£$

\footnotetext{
57 'Brazil - Annual Report, 1913 - Cost of Living'-FO 371/1915/5814, p. 22.

58 'Brazil - Annual Report, 1913 - Cost of living', FO 371/1915/5814, p. 23.
} 
48.030.000 e empregando 168.764 trabalhadores no início de 1913. O valor total da produção era estimado em $£ 54.000 .000$ e algo como $75 \%$ das necessidades de consumo eram atendidos por fábricas. ${ }^{59}$ Apesar do elevado percentual de suprimento, há que se ter em conta que os insumos que estes estabelecimentos utilizavam eram majoritariamente importados e, portanto, a dependência da tarifa aduaneira, da taxa de câmbio e da capacidade do país em importar era mandatória.

Tamanha necessidade de recursos tornava recorrente a pergunta sobre a instituição de um imposto de exportação federal que, além ajudar a financiar o orçamento da União, serviria para direcionar os investimentos na produção das commodities brasileiras, evitando crises de excesso de produção, principalmente. Além do motivo mais evidente, isto é, a redução no lucro do negócio do café, a cobrança de um tributo sobre as exportações nunca foi opção efetiva porque a obtenção de ouro seria obstada, inibindo as importações que refluiriam em um cenário de taxa de câmbio desvalorizada, aumentando o preço dos produtos importados e diminuindo a arrecadação da renda aduaneira. ${ }^{60}$ Havia ainda outro elemento a ser somado à complexa situação das finanças públicas: como o governo poderia administrar a situação de substituição de um tributo como o imposto de importação, por um tributo como o imposto sobre o consumo ou o imposto sobre a renda. $\mathrm{O}$ imposto de importação está atrelado à origem do tributo, criado para fazer frente à demanda comercial (proteção da produção doméstica), monetária (controle da inflação) e, no limite extremo, cambial (administração das reservas do país), mas nunca deveria ser empregado com objetivos fiscais porque a arrecadação de um tributo desta natureza não pode depender de tantas variáveis ao mesmo tempo como superávit comercial e a formação dos termos de troca; renda interna que permita a participação no comércio internacional; e o câmbio, dependente da balança comercial, do fluxo internacional de capitais e da capacidade do país em contrair poupança externa por meio de empréstimos. $\mathrm{O}$ sistema tributário que depende de tributação indireta sobre a renda, como era o caso brasileiro na década de 1910, deixa as finanças públicas mais suscetíveis a crises porque o grau de redução na arrecadação destes tributos é maior, posto que dependem do consumo que, via de regra, diminui em intensidade e velocidade maiores que a renda, base da cobrança dos impostos diretos. ${ }^{61}$

\footnotetext{
59 'Brazil-Annual Report-Brazilian Industries', setembro 1913, FO 881/10286/32229, p. 38.

${ }^{60}$ WILEMAN, J. P. 'Brazil Exchange: The study of an inconvertible currency'. Galli Bros, Buenos Aires: 1896, p. 19.

${ }^{61}$ CASTRO, Viveiros de. 'A História Tributária do Brasil'. Instituto Histórico e Geográfico Brasileiro. Rio de Janeiro: 1915, p. 227
} 
$\mathrm{O}$ começo da volta à normalidade na Europa se fez perceber no mercado ao final de 1913, logo após o término da Segunda Guerra Balcânica, mas nem por isto as agruras da economia brasileira apresentaram intensidade menor, nem foi possível construir outro cenário macroeconômico uma vez que árduas questões internas não o permitiram. Este novo cenário tão somente teria que aguardar o início da guerra para ser estruturado. O maior entrave interno eram as consequências advindas com a falta de pagamento de compromissos assumidos pelo governo junto ao comércio local constituído, majoritariamente, por empresários nascidos fora do Brasil e que mantinham laços bastante estreitos com seus países de origem, situação que contribuiu para manter o pessimismo do mercado internacional em relação ao Brasil e auxiliou na manutenção da posição comprada em câmbio dos bancos que atuavam no mercado brasileiro e, com oferta reduzida de moeda conversível, a economia doméstica não demorou muito para perceber a falta de horizontes e ver a crise se aprofundar. ${ }^{62}$ Importante notar como a economia do setor público já influenciava o setor privado que não conseguiu aproveitar os ventos favoráveis que começavam a soprar da Europa em face do abandono, cada vez mais nítido, da ortodoxia monetária e da volta das emissões inconversíveis praticadas pelo Ministério da Fazenda que assim procedia para cobrir os déficits em moeda local, gerando recrudescimento da dívida interna. A emissão de apólices, mecanismo de financiamento interno adotado à exaustão, servia ao pagamento da construção de estradas de ferro, pagamento de trabalhos de saneamento, aos repasses extraordinários aos ministérios, entre outros variados propósitos. ${ }^{63}$

Apesar de o governo federal ter dado sinais concretos que os gastos deveriam ser cortados de maneira mais rigorosa, a liberdade que o Congresso tinha em autorizar créditos especiais comprometia todo e qualquer plano de ajuste. A irresponsabilidade fiscal dos deputados era plena, pois as autorizações de gastos extraordinários eram feitas para atender demandas as mais diversas e nunca eram acompanhadas das respectivas fontes de receitas. Pior, não havia quase nada que o presidente da República pudesse fazer, a não ser que ele estivesse disposto e preparado para enfrentar um clima de revolta, caso afrontasse as deliberações do legislativo por meio de vetos. Esta regra da democracia brasileira que permitia a descentralização dos gastos públicos era um dos grandes atritos com a comunidade

\footnotetext{
${ }^{62}$ Retrospecto Comercial 1913, p. 5.

${ }^{63}$ Mensagem ao Congresso, 1913, p. 137; Mensagem ao Congresso Nacional, 1916, p. 134.
} 
financeira e diplomática britânica à época da análise dos pedidos de ajuda financeira do governo brasileiro. ${ }^{64}$

A construção de vias férreas, por exemplo, era de suma importância para as finanças públicas nacionais, não tanto a fim de promover uma melhor integração logística nacional em um país continental como o Brasil, mas pelo motivo de a aprovação de projetos e a busca de financiamentos indicarem, invariavelmente, que seriam liberados recursos que abasteceriam as receitas públicas, dando fôlego às despesas já previstas e não financiadas dos orçamentos. As finanças públicas estavam sobrecarregadas com os empréstimos e o serviço da dívida originada com a expansão desmesurada nas ferrovias durante os governos de Afonso Penna e Nilo Peçanha. Eram tantos contratos, dos mais variados fitos, que nem o governo sabia com certeza quantos quilômetros tinha cada trecho encomendado, quantos ramais teria cada estrada de ferro, quais eram as especificações técnicas, se haveria exigência técnica específica para os mais variados tipos de terrenos e de clima do país, quais eram as demandas logísticas das regiões que seriam atendidas, enfim, tantos e tão complexos elementos que o controle sobre a implantação das ferrovias ficava, na prática, nas mãos das empresas contratadas, todas de capital estrangeiro, a maioria britânicas. Documentos classificados como secretos pela diplomacia britânica mostram que o controle que o governo tinha sobre o retorno financeiro dos investimentos era praticamente nulo, pois quase tudo dependia de relatórios das empresas que executavam os projetos e a auditoria sobre estes documentos era impossível. Várias ferrovias já nasciam improdutivas e assim permaneciam. A perda de recursos foi expressiva ${ }^{65}$

No início de 1913, o valor total acumulado dos investimentos em ferrovias era estimado em $£ 66$ milhões e a pergunta era como saber se estes investimentos realmente aumentaram a riqueza nacional, se um país como o Brasil poderia concentrar proporcionalmente tanto capital em um só setor da economia. Em um dos muitos encontros entre diplomatas britânicos lotados no Rio de Janeiro e o ministro da Fazenda, Francisco Sales foi perguntado se ele poderia indicar ao governo britânico quais eram as prioridades do Brasil na alocação dos recursos em ouro no longo prazo, quais eram as estratégias para o futuro do Brasil. Não houve resposta formal, apenas elucubrações. Em outro momento, este na presença do Presidente Hermes da Fonseca, a pergunta foi sobre o impacto dos investimentos ferroviários na riqueza do Brasil. Londres, implicitamente, queria saber se havia estudos indicando a capacidade do capital investido em ferrovias alavancar o

\footnotetext{
64 'Brazil - Annual Report, 1912 - General Conclusions', setembro 1913, FO 881/10286/32229, p. 33.

65 'Financial Outlook in Brazil', 19 maio 1913, 371/1580/22788, p. 423-423A
} 
patrimônio nacional, permitindo ao país a diversificação da economia e das oportunidades de negócios. O ministro respondeu que, até aquele momento, não havia sido possível organizar os dados e estimar o patrimônio nacional. ${ }^{66}$ Se não havia como sequer estimar o patrimônio nacional, a questão sobre o grau do impacto das inversões em ferrovias na riqueza nacional passava a ser matéria secundária.

Os valores envolvidos no negócio de construção e encampação de estradas de ferro atingiram o equivalente à metade do orçamento para o exercício de 1914. Além de custoso, o negócio estradas de ferro era complexo e envolvia interesses internos e externos que ultrapassavam o problema da logística de um país continental como o Brasil. Em termos internos, representava a movimentação de recursos que agradavam os estados mais poderosos, como São Paulo, Minas Gerais e Rio de Janeiro, entes federativos que dependiam das exportações como principal fonte para a geração de renda pública e privada, regiões onde as elites ligadas ao negócio primário-exportador tinham amplo poder sobre questões públicas e, por isto, exigiam a construção de linhas férreas. As estradas de ferro representavam, ainda, a inserção mais completa do Brasil na divisão internacional do trabalho, basicamente porque os empreendimentos eram de valores elevados e orçados em moeda forte, em ouro, que, no final das contas, tinha que ser tomado como empréstimo do exterior, invariavelmente com apoio dos banqueiros ingleses da Casa Rothschild.

Estes recursos eram repassados em moeda local aos empreendimentos ferroviários, movimentando a economia local, mas o maior beneficiário era inegavelmente o governo federal que engordava o orçamento no seu ponto mais vulnerável, a aquisição de moeda conversível. Esta situação deixava as contas públicas em um ciclo vicioso porque a aparente calma no setor externo provocada pela entrada de recursos estrangeiros era, na verdade, o combustível de crises futuras dado que estes recursos aumentavam os gastos públicos, pressionando a dívida interna, que, somada à dívida externa, deixava o país sempre à beira da insolvência. ${ }^{67}$ Comparando os dados de 1912, desde o funding loan de 1898 a dívida externa mais que triplicou, saltando de $£ 34.697 .300$ para $£ 94.316 .600$, enquanto a dívida interna passou de Rs. 595.737:300\$000 para Rs. 642.852:600\$000. ${ }^{68}$ Estes dados são indicativos de um relativo sucesso na condução da política monetária e no controle da emissão de curso forçado, mas, nas contas externas, ficava evidente o precipício à frente da economia brasileira.

\footnotetext{
66 'Financial Crisis in Brazil', FO 371/1580/22789, 19 maio 1913, p.36.

${ }^{67}$ Mensagem ao Congresso Nacional, 1915, p. 74.

68 'Brazil - Annual Report, 1912 - Growth of Debt in recent Years', setembro 1913, FO 881/10286/32229, p. 32.
} 
A escalada de gastos em ouro não encontraria contrapartida de receitas na mesma velocidade, bastando um simples revés na entrada de divisas, como aconteceu com as exportações de borracha, para que uma grande crise se instalasse.

Esta era a situação financeira do Brasil no período que antecedeu a guerra. O país, mais uma vez, estava prestes ter as atividades econômicas paralisadas por falta de ouro. $\mathrm{O}$ cenário parecia ainda mais difícil no início de 1914 porque a depreciação da moeda entrara em ritmo frenético, mas, contra todos os prognósticos, o clima era esperançoso para um novo empréstimo porque o governo brasileiro passou a contar com o apoio do Ministério das Relações Exteriores do Reino Unido que se encarregou de pressionar os Rothschilds em razão de os investimentos britânicos dependerem de um mínimo de estabilidade macroeconômica para que uma quebradeira geral fosse evitada, salvaguardando os recursos estrangeiros aplicados no Brasil. Londres via aquele momento como de risco muito alto de perda total do capital investido, temor que, se comprovado, forçaria o abandono do mercado brasileiro pelos capitalistas bretões. ${ }^{69}$ Este cenário estava longe dos planos do Ministério das Relações Exteriores que, como se pode observar em diversos documentos da época, temia perder ainda mais terreno na economia internacional para outros países.

Este temor Londres já sentia em relação ao capital alemão aplicado no Brasil, como mostram muitos documentos que ficaram 50 anos classificados como secretos e mostram que, conforme a guerra se aproximava, o capital norte-americano ficava cada vez mais agressivo, com vários exemplos de avanços sobre o Brasil. ${ }^{70}$ Londres mantinha com Washington uma relação de confiança ciclotímica. Para assuntos envolvendo movimentação militar estratégica, a confiança era de primeira ordem, mas quando o assunto eram negócios, aí tudo mudava porque circunspecção passava a reinar.

O caso da visita de Lauro Müller aos Estados Unidos é sintomático. O receio das negociações que poderiam advir de visita oficial do ministro das Relações Exteriores a Washington foram motivo de extensa troca de memorandos diplomáticos. ${ }^{71}$ Londres estava certa que Lauro Müller tinha como propósito substituir o Reino Unido pela Alemanha e pelos Estados Unidos nas relações comerciais e financeiras com o Brasil. O pior é que o Ministério das Relações Exteriores acreditava que ele agia assim a mando de Berlim. Na verdade, o

\footnotetext{
69 'Conversation with Mr. Wileman on the gloomy outlook of the financial situation in Brazil', 19 maio1913, FO 371/1580/22768, p.35.

70 'South and Central America: General', 03 março 1913, FO 371/1580/9883, p. 309-16.

71 'Proposed Visit of Brazilian M.F.A. to United States', march 1913, FO 371/1580/9883, p. 306-359.
} 
convite para o encontro oficial partira de Washington, interessado que estava em ampliar o raio de atuação dos interesses norte-americanos no mundo. Muitas empresas de capital americano procuravam as autoridades do seu país em busca de suporte para poder atuar no Brasil porque tinham convicção que o país do café e da borracha traria grandes lucros para suas matrizes. A atenção que a diplomacia britânica prestava a Lauro Müller ganha outros contornos com a leitura de documentos que o Reino Unido classificou como secretos e que tratavam do receio maior dos britânicos que era a provável candidatura do ministro à sucessão presidencial. Esta possibilidade de Lauro Müller ser o novo presidente do Brasil significava, no entender de Londres, o fim das vantagens financeiras que o capital britânico obtinha no Brasil, por isto tanta atenção à visita aos Estados Unidos por que os interesses americanos no Brasil seriam tão elevados que eles estavam dispostos a dar todo apoio necessário para que Müller ocupasse o lugar de Hermes da Fonseca. Como se sabe, o mais longe que a carreira de Lauro Müller alcançou, seja por questões de política interna ou externa, foi mesmo continuar no Ministério das Relações Exteriores até que ele fosse substituído por Nilo Peçanha em 1917, após muita pressão de Londres.

A obsessão dos britânicos para com os alemães era questão muito anterior às mudanças que estavam ocorrendo no mundo no início do século XX. Qualquer conquista do povo da Europa Central se transformava em autocrítica no Reino Unido, provocando estudos e projetos de como barrar os concorrentes europeus que estavam cada vez mais agressivos no comércio internacional desde que forçaram a França a admitir a derrota na guerra de 1870-1. Os cuidados dos britânicos não eram infundados e deveriam até ser mesmo redobrados porque, em se tratando de comércio exterior na América do Sul antes da guerra, o capital alemão era preponderante em negócios extremamente lucrativos, como o trigo na Argentina, o café do Rio de Janeiro e a borracha do Pará. ${ }^{72}$

O Brasilianische Bank für Deutschland atuava no Brasil desde 1887 em negócios os mais variados. O sucesso obtido permitiu que a instituição passasse a representar o Direction der Disconto - Gesellschaft - Berlin e o Norddeutsche Bank in Hamburg em diversas cidades brasileiras como Rio de Janeiro, São Paulo, Curitiba, Porto Alegre, Manaus, Belém. O objetivo era estar presente em praças que tivessem maior relação com atividades de comércio exterior. $^{73}$

\footnotetext{
72 'British Trade with Brazil', 04 janeiro 1910, The Brazilian Review, p. 7.

73 'The Brazilian Review', 01 abril 1913, p 314.
} 
Fica nítida a disposição britânica de evitar perder a posição de destaque que eles ainda ocupavam no Brasil, principalmente no papel de maiores financiadores da economia nacional. O empréstimo que se discutia no início de 1914 serviria a um duplo propósito porque tanto poderia salvar o Brasil quanto serviria como garantia de manutenção das bases do Império Britânico na América Latina. O valor discutido em abril de 1913 já era algo em torno de 12 milhões de libras e havia plena disposição dos banqueiros, especialmente britânicos e franceses, em discutir as regras e garantias para a obtenção do empréstimo, do novo funding loan. ${ }^{74} \mathrm{O}$ problema era chegar a um denominador comum porque, mesmo em posição de inferioridade, o governo de Hermes da Fonseca se recusava a aceitar cláusulas consideradas aviltantes, ou ao menos assim tentava deixar público. Ajustes foram executados e a assinatura do contrato parecia muito próxima de ser efetivada em junho de 1914, mas os eventos em Sarajevo alteraram radicalmente as perspectivas para a economia global e as discussões com os banqueiros estrangeiros voltaram à estaca inicial.

\section{Seção 2.2 - Câmbio e o fim da Caixa de Conversão}

A taxa cambial entre o final de 1906 e meados de 1914 foi administrada pela Caixa de Conversão, instituição financeira vinculada ao Ministério da Fazenda, criada com base em projeto de lei do deputado federal David Campista e regulamentada pelo Decreto ${ }^{\circ} 1575$ de 6 dezembro 1906. O deputado, que posteriormente seria ministro da Fazenda durante o governo Afonso Penna, se destacava na defesa do setor cafeeiro e de políticas econômicas que resolvessem os maiores entraves para o aumento do lucro e da expansão do setor.

O presidente Rodrigues Alves foi opositor do projeto de estabilização cambial, refletindo a opinião da Câmara do Comércio e da imprensa nacional, especialmente o Jornal do Commercio. Até mesmo os comerciantes britânicos estabelecidos no Rio de Janeiro, que viviam reclamando da falta de estabilidade na economia brasileira, eram contrários à intervenção no câmbio e alegavam como principal motivo para este posicionamento a falta de credibilidade que o governo brasileiro adquirira ao fracassar em tentar estruturar a política econômica em ocasiões recentes. Embora uma taxa de câmbio estável fosse desejável para os negócios comerciais, o que mais incomodava as casas inglesas de comércio era o medo do

\footnotetext{
74 'Des Réclamations Françaises - Les Banques Interessées’, julho 1914, FO 371/1916/32512, p. 153-5.
} 
tinkering the currency, isto é, receio das consequências negativas que sucederiam quando o governo mexesse com a moeda, porque o risco de se perder o controle dos efeitos colaterais sobre a macroeconomia não compensavam a aventura da estabilidade cambial por meio do currency board que se estava prestes a tentar com o estabelecimento da Caixa de Conversão.

O tema da estabilização cambial dominou as discussões da classe empresarial, especialmente no Rio de Janeiro e em São Paulo, levando os analistas de negócios britânicos que conheciam o Brasil e conviviam com as idiossincrasias do país a se espantar com tanta atenção dada para apenas um setor da economia, a cafeicultura. ${ }^{75}$ Depreende-se das impressões da diplomacia estrangeira em geral que o Brasil deveria acordar para as evidências que mostravam o ponto de inflexão do mercado de café, tanto pelo esgotamento natural de um setor que já apresentava lucratividade decrescente quanto para as inexoráveis mudanças que adviriam com a entrada dos Estados Unidos nas pontas de demanda e de distribuição do produto, alterando radicalmente as regras do mercado. Atender somente as demandas da economia cafeeira em um país que apresentava escassez crônica de ouro, ausência de diversificação produtiva e alta concentração de renda, era o grande problema do Brasil, e não um câmbio valorizado decorrente de acúmulo de ouro por exportação de produtos primários.

O governo britânico se extenuava em repetir que a falta de cuidado com o dinheiro, público ou privado, era o grande mal que a sociedade brasileira causava à economia. $\mathrm{O}$ apego aos tempos quando a produção e as exportações do café brasileiro eram inferiores à demanda mundial e o dinheiro era farto era tempo sem volta. Agora, com uma situação muito mais difícil, na qual o lucro no negócio do café somente atingia parte do que havia sido em 1893, a produção tinha que ser cada vez maior para compensar a queda nos preços, e o ciclo negativo se instalava porque o preço da saca do produto tendia à contração. ${ }^{76}$

Para se conseguir a estabilidade cambial que os empresários ligados ao café tanto desejavam para proteger os seus interesses seria necessário um mecanismo que agisse em tempos de otimismo, de entrada elevada de ouro no Brasil, daí o sucesso relativo da Caixa de Conversão desde que começou a operar em 1906 até o fim das emissões conversíveis no primeiro semestre de 1914 quando o otimismo e a euforia já há muito não perfaziam o cenário econômico mundial e a fuga de capitais se instalou. $\mathrm{O}$ modelo considerado exitoso era o que vigorava na Argentina, economia que estava em situação bastante superior à brasileira em

\footnotetext{
75 'Caixa de Conversão or Conversion Scheme', 29 outubro1906, FO 368/8/36462, p. 328-40.

${ }^{76}$ Para exemplos de Paris como referência para consumo e lazer para a elite brasileira, ver O Estado de S. Paulo, 10 janeiro 1913, p. 6; O Estado de S. Paulo, 25 maio 1913, p.4.
} 
termos de entrada de ouro por meio de exportações de produtos primários com menor elasticidade-renda que o café, como trigo, milho, couro e lã. A pressão sobre o câmbio argentino contava ainda com vultosos investimentos estrangeiros que em 1913, mesmo com a crise, foram da ordem de $£ 646$ milhões, sendo metade proveniente do Reino Unido. ${ }^{77}$ Esta conjuntura fez a renda per capita do país superar em quatro vezes a brasileira um pouco antes da guerra. Investimentos britânicos no Brasil em 1913 foram cerca de 40\% inferiores ao montante que a Argentina recebeu, mas Estados Unidos pareciam preferir o Brasil, pois, no mesmo ano, destinaram ao mercado nacional $25 \%$ de recursos a mais que ao país vizinho. ${ }^{78}$ Interessante notar que os Estados Unidos preferiam o Brasil porque acreditavam nas possibilidades do país, mas também porque não encontrariam uma ligação já tão consolidada de negócios como a que havia entre Buenos Aires e Londres.

Definido que o câmbio no Brasil deveria ser enquadrado no padrão ouro, o problema passou a ser definir quanto deveria valer a libra inglesa. Os metalistas defendiam o valor ao par do mil-réis de volta ao patamar que havia sido fixado em 1846, isto é, a 27 d., mas a realidade à época da criação da Caixa estava muito distante deste ponto, com o pence oscilando entre 5,5 d. e 18 d. entre 1896 e 1906, período forte aumento da inflação no início da República, o Encilhamento, as batalhas em Canudos e a Revolta da Marinha. Como se não bastasse, o ouro que viabilizava o comércio importador gerava a renda aduaneira, a principal fonte de financiamento para o setor público que, com estes recursos podia honrar compromissos com fornecedores locais, pagar salários, contratar obras que também poderiam ser fonte de ouro, como a construção de ferrovias e, finalmente, a renda aduaneira que servia como garantia para a obtenção de empréstimos junto aos banqueiros da Casa Rothschild, agentes da dívida externa brasileira e dos novos empréstimos, vitais para financiar o balanço de pagamentos com frequência cada vez maior.

Além da questão do financiamento interno e das garantias ao mercado financeiro internacional, o Ministério da Fazenda utilizava o sistema de preferências tarifárias para atingir alguns objetivos específicos nas relações internacionais. Com os Estados Unidos, por exemplo, evitou-se aplicar o aumento geral de tarifas de importação por receio de retaliação na admissão de café brasileiro no mercado norte-americano em um momento no qual dois problemas já estavam na ordem do dia: o aumento nas dificuldades para exportar borracha em

\footnotetext{
${ }^{77}$ ALBERT, Bill. 'South America and the First World War', Cambridge University Press, Cambridge: 1988, p. 13 e p. 147.

${ }^{78}$ ALBERT, Bill. 'South America and the First World War'. p. 309.
} 
consequência da concorrência com os produtores asiáticos e o recrudescimento das medidas da Promotoria Geral de Nova York sobre o esquema de valorização do café brasileiro depositado na Dry Dock Company. ${ }^{79}$ Apesar de o governo brasileiro ter concedido um percentual ainda maior de preferência tarifária aos Estados Unidos, a justiça de Nova York obrigou, de imediato, a venda de um milhão de sacas armazenadas em território norteamericano.

A crise de 1913 afetou com muita intensidade países com economias comparáveis a do Brasil, como México e Argentina que também passaram por sérios problemas, mas de naturezas diferentes dos que acometeram a economia brasileira. Na Argentina, a crise esteve mais relacionada aos bancos que sofriam com a falta de crédito no exterior, com custo de vida em elevação e com investimentos estrangeiros que passaram a apresentar baixa rentabilidade, caso das ferrovias que ligavam Buenos Aires às regiões produtoras de trigo, carne e couro. ${ }^{80}$ Já no México, o agravamento das finanças públicas fez o governo implantar esquema de valorização da moeda local por meio da emissão de notas conversíveis lastreadas em prata e ouro e, para garantir a aquisição dos metais no mercado local, foi aprovada taxa de exportação proibitiva. $^{81}$

Como no Brasil, ao contrário do México, as fontes de ouro e prata eram muito reduzidas e as exportações dependiam do café, produto mais sujeito a crises que o trigo argentino. As obras de infraestrutura é que complementavam as fontes de moeda forte. Dois bons exemplos foram o empréstimo intermediado pelos Rothschilds e celebrado em março de 1911 para obras no porto do Rio de Janeiro no valor de $£ 4.500$ milhões, e o empréstimo para a construção da Rede de Viação Cearense a cargo da South American Construction Company no valor de $£ 2.400$ milhões. Este caso ficou marcado na história da dívida externa brasileira porque, contrariando a expectativa natural em ter como fiel depositário do empréstimo a Casa Rothschild, o governo brasileiro escolheu o 'The Russian Commercial and Industrial Bank of London', instituição desconhecida até mesmo na capital britânica. Como previsto pelos críticos da transação, os problemas para obter os recursos foram de toda ordem, principalmente porque a empresa incumbida da construção da ferrovia declarou falência,

\footnotetext{
79 'Brazil - Annual Report, 1912 - Relations with the United States', setembro, 1913, FO 881/10286/32229, p.14.

80 'Argentina, Causes and Effects of the Serious Economic Crisis', março 1914, CO 323/633/10564, p. 448-52.

81 'Mexico, Financial Situation', abril 1914, CO 323/633/12589, p. 497-505.
} 
obrigando Pandiá Calógeras a proceder muitas diligências junto ao tesouro do Reino Unido na tentativa de salvaguardar os recursos obtidos pelo Brasil. ${ }^{82}$

As ferrovias fizeram parte do núcleo das questões mais importantes da economia brasileira da época. Negociações para a construção ou para a ampliação da estrutura ferroviária brasileira envolviam, normalmente, a Casa Rothschild e contavam com forte aparato do Ministério do Exterior do Reino Unido porque interesses de grandes grupos empresariais britânicos estavam em jogo. Em caso sintomático registrado pela diplomacia em Londres, a expansão de uma linha ferroviária que ligaria a região de Itabira, importante produtora de minério em Minas Gerais, ao Porto de Vitória, e a construção de uma siderúrgica tiveram negociações suspensas porque, alegou o governo brasileiro, o desejo era que a planta ficasse próxima ao local de extração do minério, mas, de acordo com os diplomatas britânicos, o projeto não pode ser continuado porque alguns senadores estavam exigindo $£$ 270.000,00 para sancionar o convênio. Para uma ideia da proporção deste valor, empreendimentos industriais de médio porte poderiam ser estruturados com este capital. Como os Rothschilds se recusavam a pagar a propina exigida, o valor foi, posteriormente, reduzido para algo como $£ 170.000,00$, mas, mesmo assim não houve acordo e nem ramal muito menos a aciaria foram viabilizados. ${ }^{83}$ Situações deste tipo eram sempre lembradas à mesa de negociações quando o governo brasileiro solicitava recursos dos banqueiros internacionais. Serviam como exemplo da maneira pela qual os interesses do país eram tratados pelos políticos.

As gigantes possibilidades de lucro com minério de ferro do Brasil não foram, porém, esquecidas. Especialistas internacionais contratados pela chancelaria britânica estimavam que investimentos de até $£ 30.000 .000$ poderiam permitir o transporte de aproximadamente cinco milhões de toneladas/ano. ${ }^{84} \mathrm{~A}$ falta de divisas no Brasil para a importação da estrutura necessária para a extração e exportação do ferro eliminava a possibilidade de um empreendimento com capital nacional ocupar este nicho de mercado. A grande preocupação da missão diplomática e das empresas britânicas era com empreendedores dos Estados Unidos que já estavam bastante adiantados em lucrar com as montanhas de minérios em Itabira e, portanto, algo urgente deveria ser feito por Londres, caso contrário o capital britânico ficaria fora desta possibilidade enorme de lucro. Depreende-se dos relatos da chancelaria britânica

\footnotetext{
${ }^{82}$ CAVALCANTI, Jacob. 'Histórico da Dívida Externa Federal', Imprensa Oficial, Rio de Janeiro: 1923, p. 47.

${ }^{83}$ 'Brazil. Annual Report, 1912. Relations with Great Britain', FO 881/10286/32229, p. 11-2.

84 'Annual Report. Brasil. Mining and Agricultural. Iron Ore in Minas Gerais', setembro 1913, FO 881/10286/32229,p. 39.
} 
que a operação para retirar o minério de ferro seria incomparavelmente mais simples que o esforço empregado à época para lucrar com o látex.

Em 1905, aos investimentos de vulto na malha ferroviária, em saneamento e em portos foram somados os superávits na balança comercial resultando no ponto que aumentou as discussões sobre a estruturação da Caixa de Conversão no cenário econômico brasileiro. Foi neste ano que a valorização do mil-réis sobre a libra esterlina ficou patente, processo que já vinha de alguns anos, com grande possibilidade de continuar e prejudicar ainda mais a economia cafeeira que não estava conseguindo apoderar-se do significativo aumento no preço da saca do café no mercado internacional, como mostra a Tabela 2.2.

Tabela 2.2 - Variação (\%) no preço da saca de café (mil-réis) e na taxa de câmbio (libra esterlina), 1898/9 - 1904/5.

Café nr. 7, em Nova York

(saca $60 \mathrm{~kg}$ )

\begin{tabular}{|c|c|c|c|}
\hline & $1898 / 99$ & $1904 / 05$ & Variação \\
\hline$£$ & 6,28 & 8,13 & $29,0 \%$ \\
\hline Rs. & $7 \$ 895$ & $4 \$ 917$ & $-37,9 \%$ \\
\hline
\end{tabular}

O problema maior dos cafeicultores era o fato de os custos da produção e de grande parte do negócio do café ocorrerem em mil-réis, mas as vendas eram originadas em ouro, expresso em marcos, francos ou dólares cotados em libras esterlinas nas praças financeiras da Europa e em Nova York. A dificuldade que mobilizou os cafeicultores foi que o aumento no preço do café em libras, desde o final do século XIX até 1906, foi de aproximadamente de $30 \%$ e este lucro não pode ser contabilizado pela economia cafeeira porque houve valorização do mil-réis em torno de 37\%, como indicado na Tabela 2.2. Nas contas que os empresários ligados ao café fizeram, cotações do mil-réis acima de $15 \mathrm{~d}$. provocaram desvalorização na cotação do café na moeda local, não cobrindo os custos inerentes ao negócio. É por esta razão que os cafeicultores utilizaram todo o seu poder no sentido de que fosse estruturado em esquema capaz de impedir a cotação do mil-réis acima de 15 d., e foi com base neste câmbio que a Caixa de Conversão se estruturou. Na verdade, o que os cafeicultores queriam mesmo era cotação fixa de até 12 d., mas acabaram cedendo porque havia no governo quem defendesse firmemente a apreciação do mil réis pelo seu valor ao par como fixado na Constituição, ou seja, em 27 d. 
A apreciação do mil-réis ocorria porque ao saldo positivo em ouro não correspondeu aumento equivalente da base monetária que, como indica a Tabela 2.3 , teve pequena variação positiva até 1905, resultado da ortodoxia no Ministério da Fazenda, primeiro com Joaquim Murtinho (1898 - 1902) e depois com Leopoldo de Bulhões (1902 - 1906) como ministros da pasta.

Tabela 2.3 - M1 - papel moeda em poder do público - fim do período. (conto de réis, mil)

\begin{tabular}{l|l|l}
\hline & \multicolumn{1}{c}{ var. \% } \\
1901 & 524,7 & $-1,39 \%$ \\
1902 & 517,4 & $-2,17 \%$ \\
1903 & 513,3 & $6,52 \%$ \\
1904 & 558,9 & $-0,38 \%$ \\
1905 & 522,7 & $14,73 \%$ \\
1906 & 602,0 & \multicolumn{2}{l}{} \\
Fonte: Estatísticas históricas do Brasil: séries econômicas, demográficas e \\
sociais de 1550 a 1988. 2. ed. rev. e atual. do v. 3 de Séries estatísticas \\
retrospectivas. Rio de Janeiro: IBGE, 1990.
\end{tabular}

Nota-se que em 1906, como provável resultado das pressões internas, a base monetária variou $14,73 \%$, mas, mesmo assim, isto não foi suficiente para frear a desvalorização da libra inglesa que, ao contrário do que se poderia imaginar, não ajudava a melhorar em grande medida o poder de compra da população dado que estes ganhos eram limitados pela tributação do imposto sobre o consumo de produtos importados, principal fonte de recursos do governo, tanto em ouro quanto em moeda não conversível. Afora o governo, o setor que mais nitidamente se beneficiava com o mil-réis mais forte era o comércio importador que, frente às oscilações na taxa cambial, aprendeu rapidamente a especular. $\mathrm{O}$ comportamento dos importadores era monitorado no Rio Janeiro, por exemplo, pela representação diplomática do Reino Unido como forma de instruir empresas de capital britânico a participar do mercado brasileiro.

A variação nas taxas de câmbio forçava o comércio a acompanhar com muita atenção as cotações para que pudessem especular, aumentando preços quando o mil-réis se desvalorizava, mas não diminuindo suas margens quando havia apreciação da moeda. A representação britânica observou que os pequenos comerciantes, com destaque para italianos e sírios, aproveitavam o aumento na taxa de câmbio para enviar recursos para suas famílias nos países de origem. Por tal comportamento era possível acompanhar o câmbio com o movimento em volta de um banco italiano, por exemplo, dado que, quando a libra ficava mais 
acessível, os comerciantes estrangeiros remetiam valores ao exterior em proporção que chegava até mesmo a drenar as reservas do Brasil, provocando ainda mais instabilidade na taxa cambial. ${ }^{85}$ A Caixa poderia funcionar, esperava-se, como uma espécie de convencimento forçado para o reinvestimento dos lucros no Brasil, um país com tantos recursos naturais e que deveria ter a estabilidade cambial como meta porque projetos de investimentos estrangeiros eram postergados quando se verificava a impossibilidade de calcular, com um grau razoável de precisão, o retorno dos investimentos, não por conta das variáveis afeitas ao próprio empreendimento, mas devido às incertezas em relação ao câmbio, pedra angular da economia brasileira nestes anos que antecederam a guerra.

Apesar dos benefícios que uma taxa cambial estável traria para os negócios em geral, o que contou mesmo para o lançamento da Caixa foi o peso do setor cafeeiro que agiu de maneira articulada e impôs o padrão-ouro na economia brasileira. $\mathrm{O}$ governo e o Congresso cederam às pressões e foi estipulado uma paridade legal de $15 \mathrm{~d}$. para o mil-réis, ficando o Banco do Brasil encarregado das operações no mercado que impedissem a valorização acima desta taxa. O teto inicial estabelecido para o novo sistema foi de $£ 20$ milhões, valor que, quando alcançado, permitiria, com aprovação no Congresso, uma nova paridade legal com a libra, o que aconteceu em 1910 quando a cotação foi oficialmente alterada para 16 d. Apenas as notas emitidas pela Caixa eram livremente conversíveis em ouro, característica que impunha ao sistema cambial a convivência com dois tipos de notas em mil-réis e que circulavam ao mesmo tempo, a maioria inconversíveis e que não eram emitidas pela Caixa de Conversão. É por esta razão que o sistema cambial brasileiro entre 1906 e 1914 pode ser considerado misto ou mesmo como padrão-ouro à margem. ${ }^{86}$

Apesar do propósito da Caixa de Conversão nunca ter sido o de transformar toda a base monetária em moeda conversível, ao menos as oscilações cambiais cessariam. A libra mudava consideravelmente de valor não apenas com frequência semanal, mas até mesmo intraday, para desespero do comércio varejista. As especulações financeiras reinavam no mercado e quando os agentes econômicos percebiam que havia incertezas nas ações do governo, e isto era bastante comum, a oscilação cambial era apenas o termômetro dos problemas macroeconômicos. Em um período de superávit cambial e de relações amistosas com os banqueiros estrangeiros, a tendência para o câmbio era de valorização, mas estes fatos,

\footnotetext{
85 'Conversion Scheme - Project', 29 outubro 1906, FO 368/8/36462, p. 317-27.

${ }^{86}$ Ver OLIVEIRA, Maria Teresa Ribeiro e SILVA, Maria Luiza Falcão. 'O Brasil no padrão-ouro: a Caixa de Conversão de 1906-1914'. In: História Econômica \& História de Empresas IV, I. São Paulo: Editora UCITEC, 2001, p. 83-114.
} 
apesar de positivos, eram sempre intermediados por notícias que afetavam o valor do ouro e, por isto, não permitiam o planejamento adequado de uma empresa.

Em uma análise mais ampla, o sucesso da Caixa foi limitado porque não atingiu sequer metade da base monetária, e nem poderia ter sido diferente por que a conversão ao ouro dependia de muito mais do que boa vontade e pressão do setor do café. Dependia de o país acumular reservas para a livre conversão e isto jamais teria sido possível com os orçamentos que já nasciam deficitários e ficavam ainda menos financiáveis ao longo do exercício fiscal. O primeiro passo, difícil, mas prioritário, seria abandonar, proibir legalmente até, que dívidas e despesas continuassem a ser liquidadas com títulos públicos, procedimento empregado ad nauseam por sucessivos governos e que deixava somente uma certeza, a de que os recursos do futuro estavam sendo consumidos e não investidos.

As expectativas iniciais eram que a conversão ao ouro se estenderia à integralidade da base monetária. Conforme o mercado foi vivenciando a nova prática, ficou patente que a política econômica não mudaria além do ponto da estabilização cambial, possível quando o ouro tendia à desvalorização. Se houvesse uma reversão nas expectativas e o ouro tendesse à valorização, o sistema da Caixa de Conversão não teria mecanismos para contornar o problema e manter a estabilização cambial. Foi o que ocorreu em 1913.

A diminuição da entrada de ouro no Brasil começou em 1912/1913, resultado de uma sucessão de eventos negativos para o setor externo da economia brasileira que podem ser sumarizados em três tópicos:

1) Guerras nos Bálcãs. A mobilização militar e econômica na Europa levou ao entesouramento do capital financeiro. Isto praticamente retirou do Brasil a possiblidade de obter recursos em Londres e em outras praças financeiras internacionais.

2) Café. Oscilações nos preços do café foram constantes, mas em 1913 a queda nos preços do produto foi devida, principalmente, às mudanças nas operações originais de controle de mercado estabelecidas desde 1906 com a Convenção de Taubaté e que foram obstadas pela Lei Sherman. Estoques do produto nos Estados Unidos e na Europa tiveram que ser liberados no mercado. 
3) Borracha. A concorrência do produto nacional com a borracha asiática se mostrou impossível, principalmente porque empresas que dominavam o mercado internacional de pneus - como a Michelin - incentivadas pelos resultados da agressiva política francesa de ocupação de territórios no Sudeste Asiático, investiram nestes mercados como fornecedores de látex para a indústria da borracha. Os resultados vieram de maneira rápida e foram suficientes para que a região se consolidasse como nova base para a indústria da borracha em escala global.

A somatória de problemas que isoladamente já teriam graves consequências para a economia brasileira fez a crise se instalar com força. As importações que haviam apresentado números elevadíssimos em 1913 passaram pelo refluxo da crise dos Bálcãs e começaram 1914 em baixa, com a alfândega do Rio de Janeiro relatando redução de $£ 400.000$ em receitas nos dois primeiros meses deste ano em comparação ao ano anterior. Sinal claro de crise, crise que levaria ao fim da Caixa de Conversão porque, se em fevereiro de 1913 houve aumento nos depósitos no total de $£$ 433.334, em fevereiro de 1914 o resultado foi de retiradas que totalizaram $£$ 366.667. A reversão na situação positiva na Caixa começara, na verdade, bem antes. Praticamente todos os relatórios The Brazilian Review do escritório de J. P. Wileman emitidos entre o segundo semestre de 1913 até o início da guerra faziam menção à longa agonia dos saldos dos depósitos da Caixa, cada vez menores. A uma semana da deflagração do conflito mundial, os depósitos totalizaram apenas $£$ 11.135.592, o que indicava redução de $£$ 7.264.909 desde o começo de 1914, quase 35\% do valor total dos depósitos de $1906 .{ }^{87} \mathrm{Na}$ prática, estava encerrada a primeira experiência brasileira no padrão-ouro.

É possível afirmar que a experiência brasileira no padrão-ouro entre 1906 e o primeiro semestre de 1914 somente foi possível porque o país conseguiu atrair ouro e manter uma reserva que se manteve em torno de $£ 20$ milhões neste período. Quando a somatória dos fatos negativos começou a drenar as reservas da Caixa, o câmbio na praça do Rio de Janeiro registrou a mudança, especialmente a partir de julho de 1914, como mostra a Tabela 2.4 que exibe o preço do mil-réis tendo como base o que registraram os principais bancos que atuavam na Capital Federal no período.

87 'The Brazilian Review', 21/07/1914, p. 115. 
Tabela 2.4 - Taxa cambial média para a sexta-feira de cada semana até o final de junho de 1914, após, diária (libra esterlina)

\begin{tabular}{l|l|l} 
Praça: Rio de Janeiro. & Maior & Menor \\
1908 & 15,22 & 15,19 \\
1909 & 15,44 & 15,16 \\
$1910^{*}$ & 18,25 & 15,13 \\
1911 & 16,31 & 16,06 \\
1912 & 16,37 & 16,06 \\
1913 & 16,37 & 16,13 \\
1914 & & \\
até 30/06 & 16,19 & 15,75 \\
Julho & 16,09 & 14,69 \\
Agosto & 14,13 & 11,63 \\
Setembro & 13,00 & 10,44 \\
Outubro & 15,00 & 13,25 \\
Novembro & 14,13 & 13,63 \\
Dezembro & 15,13 &
\end{tabular}

Fonte: 'Bank of Brazil', 1/11865/10907, 3 maio 1915, pasta 'Treasury'.

*No dia 27/12/1910 o Senado aprovou lei fixando o câmbio em $16 \mathrm{~d}$.

Verifica-se que o grande objetivo da Caixa de Conversão, manter o câmbio em torno de 15 d. e, após 1910, 16 d., foi alcançado e este clima de otimismo pode ser visto na coluna "maior" com os mais elevados valores do mil-réis praticados no mercado e que registrou em 1910 o máximo de 18,25 d., motivo para a fixação do novo teto de 16 d. que vigorou até o fim das emissões conversíveis. Em outubro de 1914, mês da assinatura do novo funding loan, o mil-réis chegou a ser cotado a uma taxa consideravelmente baixa, 10,44 d., o que, para um país que já estava se acostumando à estabilidade cambial, indicou que havia chegado o fim das preocupações do setor cafeeiro em relação à valorização da moeda nacional, mas também que este seria o início de um novo cenário de problemas, agora com as restrições à venda de café estabelecidas durante a guerra.

Esperava-se um milagre, uma reversão do quadro negativo a partir do segundo semestre de 1914 com a entrada sazonal do ouro das exportações, mas o mercado sabia que o fluxo normal das exportações não traria o ouro suficiente para salvar a instituição e, com os sinais negativos que começaram a vir da Europa a partir de junho de 1914, a pressão por uma solução via empréstimo no exterior foi cada vez maior. O momento era apropriado para se pensar em um novo empréstimo externo porque as restrições mais drásticas ao crédito deram sinais de que estavam por terminar em fevereiro de 1914 quando as taxas bancárias em Londres tiveram redução acentuada, sinal inequívoco de que o capital que estava represado 
nas contingências europeias necessitaria de remuneração e que novos investimentos e empréstimos estariam disponíveis para o mercado brasileiro.

Os diplomatas britânicos emitiram comunicados para Londres instando os banqueiros a procurar o governo brasileiro porque o desespero por recursos em ouro no Palácio do Catete era grande, e agora, com a atenuação da crise balcânica, abria-se uma oportunidade para o capital britânico reafirmar suas relações com o Brasil. Na visão do corpo diplomático britânico, era chegado o momento ideal para forçar o governo brasileiro a contrair empréstimo e liquidar as pendências comerciais com empresas de capital britânico, casos com reivindicações antigas e que não tinham solução à vista, ao menos não pelos meios comerciais e contratuais habituais.

As negociações do novo funding loan eram vistas como a última chance para casos como o da empresa Manaos Improvements Company que teria que encerrar atividades se a pendência financeira com o Estado do Amazonas não fosse liquidada até o fim do $1^{\circ}$ semestre de 1913. Londres forçava o governo brasileiro a assumir esta e outras dívidas dos estados, mas, neste caso, o governo estadual, garantidor da dívida, dizia que negociações somente ocorreriam a partir da redução do valor cobrado pela água, motivo de grande insatisfação popular e que acabou resultando na destruição de parte importante da estrutura da empresa instalada na capital amazonense. A situação financeira do estado do Amazonas, dada a queda nos preços da borracha, era absolutamente crítica nos meses que antecederam a guerra, impedindo o Estado de resolver esta e outras pendências que envolviam empresas de outros países além do Reino Unido, caso da norte-americana Brown, Shipley and Company que atuava na área de financiamento privado mercantil e que também forçava para ver ressarcidos empréstimos junto ao governo local. ${ }^{88}$

A Estrada de Ferro Porto Alegre é outro exemplo de muito barulho nas relações do Brasil com o mercado internacional. Construída na década de 1860 com base em concessão obtida junto ao governo do Rio Grande do Sul, a ferrovia foi parte da federalização do sistema viário, quando o estado gaúcho vendeu a concessão para o governo federal que, por sua vez, negociou o empreendimento com um consórcio belga. A empresa inglesa PRC (Porto Alegre Railway Company), até então proprietária do empreendimento, se recusou a aceitar oferta de aquisição feita pelo Rio Grande do Sul trinta anos após o início da concessão, como previa o

88 'Brazil - Annual Report, 1912 - Relations with the United States'. setembro, 1913, FO 881/10286/32229, p.13. 
contrato. A empresa buscou, então, apoio da diplomacia britânica em Londres e no Brasil porque temia que, após a encampação da ferrovia, as negociações com o governo estadual entrariam em total compasso de espera e talvez até nunca fossem concluídas. A diferença entre o que a empresa esperava receber de indenização e o que o governo se propunha a pagar era de aproximadamente $£ 200.000 .{ }^{89}$ O desespero tomou conta da empresa e a Casa Rothschild, por sua afamada capacidade em arguir com o governo Brasileiro, foi contratada para intervir no caso. O resultado, depois de extensa troca de documentos, foi a encampação pelo governo federal com a justificativa que o estado do Rio Grande do Sul estava completamente coberto pela Constituição na forma como as negociações procederam. A recusa da empresa em aceitar a oferta do Estado o desobrigava a fazer nova proposta. Este caso é um bom exemplo de como a relação de submissão do Brasil ao capital estrangeiro ocorria em graus diferentes porque dependiam do contexto histórico. Cientes que Londres se posicionava mundialmente como grande defensora do respeito aos contratos e às leis, o governo federal insistiu na questão da constitucionalidade do ato do estado do Rio Grande do Sul e não abriu mão deste ponto mesmo nos momentos de maior tensão, quando a necessidade de divisas era atroz. O caso ainda foi discutido durante uma das fases de negociação do novo empréstimo consolidado, mas a posição do Rio de Janeiro não se alterou.

As ameaças do Governo Brasileiro em abandonar a mesa de negociações se situações como a da PRC se repetissem causaram grande preocupação em Londres porque a chance de se resolver as principais pendências comerciais e financeiras entre o capital britânico e o Brasil era justamente o empréstimo consolidado. Isto quer dizer que se o Brasil tivesse encontrado outra forma de financiamento, com os norte-americanos, como se especulou, ou mesmo uma maneira de conviver com a falta de ouro até que novos recursos viessem por meio das exportações, ou de investimentos estrangeiros, mesmo assim o empréstimo teria que se concretizar. A diplomacia britânica não poupou energia e impôs sua vontade: o Brasil teria que assinar o funding loan ou consequências muito graves seriam colocadas para o país na economia internacional. Esta medição desproporcional de forças está devidamente documentada e é esclarecedora de como funcionavam as relações do Brasil com o sistema financeiro internacional um pouco antes da Primeira Guerra Mundial. ${ }^{90}$

\footnotetext{
89 'Porto Alegre Railway Company's Claim', 20 fevereiro 1913, FO 371/1580/8169, p. 88-135.

90 'Brazilian Finance and British Claims - Loan and Outstanding Claims', março 1914, FO 371/1915/9101, p. 110-117.
} 
O que a chancelaria queria era manter o Brasil sob o julgo de Londres e resolver problemas muito complexos, que somente o funding loan permitiriam, como o famoso episódio da Estrada de Ferro Madeira-Mamoré. Os problemas neste caso foram de outra ordem porque a empresa estava registrada com capital norte-americano, mas garantido por seguradoras e bancos britânicos. Problemas de logística que impediam a chegada de equipamentos até o local das obras, problemas insalubridade com a infestação de doenças tropicais, problemas de contrato observados apenas quando a ferrovia já estava em operação, não pagavam sequer metade dos custos envolvidos na operação, enfim, havia uma miríade de questões que ameaçavam interesses financeiros britânicos na ordem de aproximadamente $£ 8$ milhões, montante que poderia simplesmente desaparecer quando o conglomerado de empresas de Percival Farquhar entrou em colapso em 1913, obrigando o governo brasileiro a assumir a ferrovia. Diversas tratativas diplomáticas foram levadas a termo por diplomatas britânicos junto ao governo brasileiro que se recusava a ressarcir os investidores afirmando que a relação contratual era apenas com a empresa de Farquhar, registrada nos Estados Unidos. Somente depois de muitas ameaças judiciais e diplomáticas é que o governo britânico conseguiu que Farquhar reconhecesse que, apesar de a empresa ter sido registrada como norte-americana, o capital que fazia a Madeira Mamoré funcionar era britânico. Após as devidas notificações, Hermes da Fonseca finalmente concordou em abrir crédito a favor de bancos e seguradoras do Reino Unido, como o Bank of Scotland, o Liverpool District Banking Company e a Speyer Brothers Company. ${ }^{91}$

O grande volume de recursos empregado no setor de logística envolveu, ainda, grande pendência comercial com a empresa Cory Brothers \& Company em relação ao fornecimento de carvão para o sistema de navios e para as ferrovias no Brasil. A Cory Brothers, munida de um número sem fim de faturas de fornecimento de carvão, pressionou governo brasileiro a obter empréstimo para pagar o que devia. ${ }^{92}$ A recusa fez com que a própria empresa buscasse os Rothschilds e forçasse o Brasil a contrair recursos específicos no mercado internacional para que a pendência comercial fosse resolvida. O receio em Londres, nas conversas entre o serviço diplomático britânico, os Rothschild e a e a Cory Brothers era que o governo brasileiro poderia aproveitar a oportunidade na qual recursos para o funding loan estavam sendo oferecidos, tomar o empréstimo e não liquidar as faturas pendentes com a empresa de carvão. Estas pendências travavam a assinatura do contrato, mas a situação ficava ainda mais

\footnotetext{
91 'Madeira - Mamoré Railway - Explain British Interests in', maio 1914, FO 371/1915/22615, p. 231-294.

92 'Claims vs. Brazilian Government', junho 1914, FO 371/1916/28348, p. 118-129.
} 
complexa quando envolvia recursos de outros países, como a França e a Alemanha. Foi o que aconteceu com os banqueiros do Hamburg Bankers que processaram o Estado de São Paulo porque queriam recuperar o valor de $£ 1.200 .000$ que garantiram, por meio de debêntures, para as operações das companhias ferroviárias 'Dourado', 'Araraquara' e 'São Paulo-Goyaz' que tiveram falência decretada na justiça brasileira, deixando o capital alemão totalmente descoberto. $^{93}$

O governo francês, assim como o alemão, também tomava medidas diplomáticas de toda ordem para poder garantir o ressarcimento de valores aplicados no Brasil, como quando tentou interferir para a solução de pendências com a Compagnie Genérale des Caoutchoucs que exigia compensação por prejuízos causados pelo governo brasileiro no mercado da borracha. ${ }^{94}$ Conforme as negociações do novo empréstimo avançavam, empresas dos mais variados setores se manifestavam junto à representação diplomática britânica no sentido de ver garantido o atendimento de reivindicações de valores devidos por empresas ou pelo governo do Brasil. Era como se uma longa fila fosse se formando e até negócios relativamente menores como o da empresa de construção civil Cambrian Buildings, que cobrava $£ 160.000$ do Governo Brasileiro por obras entregues e não pagas. ${ }^{95}$ Quando o problema era o de ameaça física aos interesses estrangeiros no Brasil, o governo federal acabou optando pela força, como na situação que envolveu a oligarquia conduzida pela família Accioly no Ceará e que provocou grave crise institucional culminando com o envio de tropas federais para evitar que recursos britânicos alocados em ferrovias fossem prejudicados. O problema ganhou dimensões tão grandes que o governo britânico decidiu pelo envio do navio H.M.S. Berwick para o Ceará na tentativa de conter a revolta por meio da dissuasão, esperando poder salvaguardar vidas de seus cidadãos e interesses financeiros. ${ }^{96}$

A negociação do novo funding loan que ocorreu antes da Primeira Guerra foi mais complexa que o primeiro empréstimo consolidado, fazendo com que os Rothschild tivessem que se associar a banqueiros de outras praças porque, além dos labirintos jurídicos, o valor em questão era considerado muito elevado para ser garantido por apenas uma casa bancária. A condução das negociações de juntar interesses muito diversos nesta operação, posto que cada instituição que se envolveu no processo representava interesses de empresas de diversos setores credoras do Governo e de empresas estabelecidas no Brasil. Os banqueiros alemães,

\footnotetext{
93 'Failure of Railways in São Paulo', março 1914, FO 371/1916/13591, p. 4.

94 'Brazilian Loan; Foreign Claims vs. Brazil', junho 1914, FO 371/1916/29067, p. 134-141.

95 'Claims of British Creditors Against Brazil', julho 1914, FO 371/1916/30561, p. 143.

96 'Situation at Ceará', março 1914, FO 371/1915/9358, p. 295-371.
} 
por exemplo, travaram o processo porque decidiram acrescentar mais uma pendência, agora relacionada à Estrada de Ferro de Santa Catarina. ${ }^{97}$

A chancelaria no Rio de Janeiro acreditava também que era chegado o tempo adequado para forçar mudanças na política econômica do Brasil. A falta de recursos começava a parar o comércio que tinha muitos títulos a receber do governo. Falências passaram a ser mais e mais frequentes. $\mathrm{O}$ importante setor têxtil estava demitindo e trabalhando apenas parte do período. Oportunidade rara, dizia o corpo diplomático no Rio de Janeiro, de colocar o Brasil no eixo correto do sistema internacional, solução que agradará os investidores britânicos e que também será apreciada pelos brasileiros, when time comes. ${ }^{98}$

Os britânicos estavam certos, ao menos em relação à situação econômica brasileira. Até a questão da monarquia, tema adormecido desde o governo de Prudente de Morais, conseguiu sobrevida na época. Movimentos no Brasil e no exterior pela volta do regime monárquico ganhavam impulso quando a situação econômica piorava, quando o governo, então, parecia administrar o país de maneira ainda mais caótica. Os jornais no Rio de Janeiro noticiavam todo e qualquer movimento da família Orleans e Bragança e alguns políticos brasileiros estavam sempre lembrando na tribuna como os tempos do Império tinham sido bons, como o país era muito melhor governado, enfim, como o Brasil realmente parecia um país respeitável. Apesar destas manifestações, tentativas reais de promover a restauração da monarquia não chegavam além de propostas apresentadas no Congresso que rejeitava os projetos sempre por ampla maioria. Na opinião de diplomatas britânicos, o herdeiro do trono de D. Pedro II deveria analisar muito bem a situação do Brasil antes de pretender levar avante esta empreitada porque a única coisa que funcionava razoavelmente bem no país e que tinha algum valor real era a Caixa por conta do ouro ali administrado. ${ }^{99}$

Apesar de as ameaças ao regime republicano não terem ido muito longe, o governo de Hermes da Fonseca, mesmo estreitamente ligado aos militares, passou a ter que enfrentar resistências de seus pares quando, por desespero, tomou medidas fora de padrão para que fosse possível obter ouro antes que a Caixa tivesse as operações travadas, isto é, antes que a economia brasileira entrasse em depressão. Duas diligências bastante controversas foram aventadas: a negociação dos couraçados São Paulo e Minas com o Governo da Grécia e a venda de três submarinos encomendados junto a um estaleiro na cidade italiana de Spezzia e

\footnotetext{
${ }^{97}$ CAVAlCANTI, Jacob. 'Histórico da Dívida Externa Federal', Imprensa Oficial, Rio de Janeiro: 1923, p. 55. 98 'Brazilian Finance and British Claims', 02 março 1914, 371/3168/9101, p. 110-124.

99 'Brazil - Annual Report, 1912 - Federal Intervention elsewhere', setembro, 1913, FO 881/10286/32229, p.22.
} 
que estavam prestes a ser entregues à Marinha do Brasil. Nos dois casos, por pressão interna, mas também por falta de condições comerciais, os negócios não se concretizaram. Os couraçados continuaram servindo a Marinha do Brasil e os modernos e caros submarinos construídos na Itália foram incorporados à esquadra brasileira, com grande repercussão na imprensa nacional e estrangeira que via tudo como sinal de muita extravagância em um país à beira da falência. ${ }^{100}$

Vistas de fora, aquisições absolutamente atípicas como a dos submarinos pareciam realmente inadequadas dada a carência de cambiais da economia brasileira, mas uma análise mais cuidadosa da história neste começo do século XX permite identificar a origem de tal conduta na configuração do mapa político do Brasil que tanta polêmica causou um pouco antes da guerra. Até 1913, as principais fronteiras do Brasil ainda não estavam definitivamente consolidadas de fato porque havia o temor que países vizinhos mais organizados militarmente, como a Argentina, tornassem públicos os questionamentos que faziam sobre as demarcações do território que foram negociadas pelo Barão de Rio Branco, ministro das Relações Exteriores, que ficou afamado pelo sucesso nas soluções que obteve por meio da diplomacia, celebrando contratos com a França (Guiana), Venezuela, Bolívia, Colômbia, Equador, Argentina e Uruguai entre 1901 e 1913. ${ }^{101}$ A convivência de Rio Branco com os seus pares nas repúblicas vizinhas fazia dele um respeitado conselheiro do poder executivo e dos militares em questões de segurança internacional, especialmente em relação ao maior de todos os receios do Brasil nesta área que eram as deliberações argentinas. Rio Branco acreditava que a instabilidade na América do Sul poderia fazer com estas incipientes democracias se transformassem em regimes ditatoriais, ameaçando o território brasileiro, e somente armas poderiam detê-los, armas potentes equipando navios de guerra que intimidassem estes países, dissuadindo-os. Não foi outro o motivo de a Marinha do Brasil ter encomendado máquinas de guerra como submarinos e couraçados que custaram vários milhões de libras esterlinas, como se especulava à época. A diplomacia europeia compreendia as inquietações brasileiras, mas o problema era utilizar recursos elevados em equipamentos que, afirmavam especialistas bélicos, eram grandes demais e totalmente inadequados para operações no Rio da Prata, exatamente o ponto de maior desassossego da política externa brasileira e que perduraria ainda por muitas décadas provocando verdadeira corrida

\footnotetext{
100 'Greece and Brazilian Battleships, 371/1915/215, 03 janeiro 1914, p. 1-4; 'Brazilian Submarines', FO 371/1915/5538, 07 fevereiro 1914, p. 211-227.

${ }^{101}$ Alguns acordos foram negociados por Rio Branco, mas assinados por Lauro Müller, seu sucessor à frente do Ministério das Relações Exteriores, casos do Uruguai e Venezuela.
} 
armamentista com Buenos Aires. O escritório diplomático britânico no Rio de Janeiro alertou veementemente Londres sobre a ocorrência destes fatos, não deixando de expor uma saída que teria sido assaz menos onerosa aos cofres brasileiros, ou seja, a solicitação explícita de apoio dos Estados Unidos contra a Argentina. ${ }^{102}$ Dadas as estreitas relações comerciais, financeiras e diplomáticas entre Londres e Buenos Aires, é de se conjecturar que esta teria uma ótima oportunidade para Washington se aproximar mais do Brasil.

Além das implicações técnicas de navegabilidade e condições de operação no Sul do Brasil, os gastos com estes armamentos eram totalmente incompatíveis com a situação de penúria das reservas nacionais em ouro e que obrigava o país a solicitar ajuda financeira internacional com muita frequência. Justificar estes gastos para os banqueiros em Londres foi tarefa das mais difíceis e é muito provável que o Brasil somente tenha continuado a obter apoio dos Rothschilds porque parte das encomendas da Marinha do Brasil foi feita junto a empresas britânicas, caso dos couraçados.

A morte do Barão do Rio Branco no início de 1912 foi motivo de lamentação pública no Brasil, inclusive com pronunciamentos do corpo de diplomatas que atuava no Brasil. Os britânicos, no entanto, tinham um motivo a mais para se preocupar por conta do sucessor de Rio Branco, Lauro Müller. Entre 1912 e 1917, período durante o qual Lauro Müller comandou o Ministério das Relações Exteriores, Londres não poupou esforços, abertos e secretos, para dinamitar a imagem do ministro, repetidamente acusado de entreguista ao Império Alemão porque, supostamente, as suas origens germânicas o colocavam sempre a favor de Berlim e, claro, contra os interesses britânicos no Brasil. Nada disto ficou provado, mas a pressão para que ele fosse substituído sempre foi muito grande e alcançou grau incontrolável durante as discussões sobre a participação brasileira na guerra. Quando do torpedeamento do navio brasileiro Paraná, Wenceslau Braz foi obrigado a deslocar Nilo Peçanha para a pasta sob ameaça de perder o apoio britânico em qualquer tipo de reivindicação ou aspiração em termos financeiros ou em aspirações globais. ${ }^{103}$

A situação ruim vivida pela economia brasileira no limiar da Primeira Guerra fez a chancelaria britânica no Rio de Janeiro comparar os dois maiores momentos de crise financeira no país após a Proclamação da República, 1898 e 1913, e chegar à conclusão que a

\footnotetext{
102 'Brazil - Annual Report, 1912 - General Foreign Policy', setembro 1913, FO 881/10286/32229, p. 3.

103 Como exemplo da campanha que o ministério das Relações Exteriores do Reino Unido promoveu contra o Ministro Lauro Müller, ver 'Brazilian Ministry of Foreign Affairs, Dr. Lauro Müller, Granted Leave', 31 maio 1916, FO 371/2640/184677, p. 9-11.
} 
situação antes do primeiro funding loan foi especialmente mais aguda porque o câmbio se descontrolou, prejudicando todos os setores econômicos. Já em 1913, graças à Caixa, a situação cambial poderia ter sido sustentada com lastro de $£ 25.000 .000$ por até dois anos, período que se esperava adequado para uma reversão de dados tão negativos. Banqueiros e grandes empresários apostavam, ainda, na recuperação do Brasil ajudado pela indústria da borracha. Porém, esta esperança, no entender da chancelaria em Londres, somente poderia se tornar realidade se fossem abandonados os planos de valorização do produto, deixando o mercado livre, condição que levaria ao Brasil indústrias poderosas que tinham a borracha como matéria prima. ${ }^{104}$ Apesar de não citadas, as empresas que comandavam o mercado de borracha antes até 1914 eram a norte-americana Goodyear e a francesa Michelin, ambas associadas a dezenas de outras empresas com atuações globalizadas e que muita influência tinham também na economia brasileira. A esperança de salvação via exportações de borracha não se confirmou porque, como visto, o preço do produto foi reduzido frente ao crescimento da oferta mundial. À esta situação adversa, somaram-se a redução no preço do café que não suportou a desova dos estoques e da nova safra no mercado, e a desconfiança em relação ao poder da Caixa em atender a demanda por cambiais que estava consumindo os depósitos.

O eminente fim da Caixa de Conversão e a demora na obtenção do novo empréstimo foram situações vistas pelo capital alemão como oportunidade de negócios lucrativos no Brasil. Corporações como Hamburg America Company, Deutsche Bank, Disconto Gesellschaft, Allgemeine Electricitätsgesellschaft, Simens, Krupp, dentre outras, formaram uma associação com o propósito de aumentar a influência do capital alemão na economia internacional. Berlim, percebendo a força desta iniciativa, decidiu dobrar o capital da associação para que os dois maiores objetivos dos empresários alemães, a América do Sul e o Extremo Oriente, passassem a receber mais investimentos na lacuna deixada pelos britânicos. ${ }^{105} \mathrm{O}$ receio da diplomacia britânica em perder posição na economia brasileira se mostrou ainda mais real, principalmente quando as exigências do governo britânico para apoiar a nova consolidação da dívida brasileira travavam a assinatura do contrato de tal forma que o mercado começou a desconfiar da liberação dos recursos.

A análise do movimento da Caixa de Conversão mostra como o mecanismo de estabilização cambial se comportou até a débâcle, até a insolvência do Brasil, e é um

\footnotetext{
104 'Brazil - Financial and political situation: reports on gloomy outlook', 05 maio 1913, FO 371/1580/20620, p. 418.

105 'Deutsche Vereinigung für Welthandel', março 1914, CO 323/633/11705, p. 491-494.
} 
excelente método para sumarizar a breve experiência nacional no padrão ouro. Houve três momentos bem distintos nos acumulados dos saldos: movimentação discreta de recursos entre dezembro de 1906 até o final de 1908; grande fluxo de recursos entre 1909 e 1912; e crise a partir do final do primeiro semestre de 1913 até o início da guerra. No início do funcionamento, a movimentação da Caixa foi bastante discreta, com relativa estabilidade nos dois primeiros anos de funcionamento quando a instituição operou com depósitos entre $£$ 5.500 milhões e $£ 6.000$ milhões. A partir do segundo semestre de 1909, o movimento na Caix passou a crescer com a entrada de seguidos depósitos que suplantaram as saídas e fizeram o saldo ao final de 1909 atingir $£ 14.080$ milhões, conforme indicado na Tabela 2.5.

Tabela 2.5 - Caixa de Conversão - total depósitos em ouro, 1909-1912 (libra esterlina)

\begin{tabular}{ll|ll|ll|ll}
\hline 1909 & & 1910 & & 1911 & & 1912 \\
$02 / 01 / 1909$ & 5.586 .879 & $08 / 01 / 1910$ & 14.122 .854 & $07 / 01 / 1911$ & 18.999 .395 & $05 / 01 / 1912$ & 24.406 .455 \\
& & & & & & & \\
$03 / 07 / 1909$ & 5.804 .410 & $02 / 07 / 1910$ & 19.999 .829 & $01 / 07 / 1911$ & 18.608 .052 & $06 / 07 / 1912$ & 22.937 .822 \\
& & & & & & & \\
$31 / 12 / 1909$ & 14.080 .235 & $31 / 12 / 1910$ & 18.999 .395 & $30 / 12 / 1911$ & 23.945 .118 & $28 / 12 / 1912$ & 25.780 .268 \\
\hline
\end{tabular}

Fonte: The Brazilian Review, diversas semanas entre 1909 e 1912.

A variação de um pouco mais de $150 \%$ em 1909 foi motivo de euforia no mercado, principalmente porque os críticos mais contumazes do sistema de estabilização cambial, como a comunidade de empresários e investidores britânicos, tiveram que concordar que o principal objetivo proposto em 1906 estava sendo atingido, isto é, o câmbio estava estável em 15 d. Não era por outro motivo que as notas da Caixa tinham aceitação no mercado, especialmente no de comércio exterior, aceitação que se transformou em referência para o sistema financeiro nacional e para as relações do Brasil com o mercado financeiro internacional como provam as edições da Brazilian Review de J.P.Wileman que passaram a publicar o balanço da Caixa na seção Money Market com destaque a partir do final do primeiro semestre de 1907. ${ }^{106}$ De 1909 ao final de 1912 os depósitos foram superiores aos saques entre o primeiro e o último dia de cada um destes anos até atingir valor acumulado de $£ 25.780$ milhões, valor $361 \%$ superior ao início de 1909. Apesar de os dados de 1912 demonstrarem nova estabilidade - a diferença entre o último e o primeiro dia do ano foi de apenas 5\% - tudo levava a crer que o Brasil tinha conseguido, finalmente, estabilizar o câmbio e que a transformação da totalidade da base monetária em conversível seria questão de tempo.

106 'The Brazilian Review - Money Market', 25 junho 1907, p. 749. 
O que não estava previsto no estatuto da Caixa de Conversão, a saída líquida de recursos conversíveis em ouro, começou a acontecer em abril de 1913, momento de grandes incertezas que emanavam dos Bálcãs e das reduções nas exportações de borracha, como mostra a Tabela 2.6. A partir deste ponto, as retiradas passaram a superar as entradas de moedas conversíveis em ouro deixando o resultado neste ano negativo em quase $30 \%$ frente ao ano anterior. Não que meses com reduções no total dos depósitos não tivessem aparecido antes, mas foi ao final do primeiro semestre de 1913 que as possibilidades de problemas na economia transformaram a Caixa, baluarte de um Brasil com economia no caminho certo, no entender dos metalistas, em termômetro da grave crise que se instalou no país.

Tabela 2.6 - Caixa de Conversão - total depósitos em ouro, 1913 (libra esterlina)

\begin{tabular}{l|l|l}
\hline 1913 & \multicolumn{2}{l}{ Variação } \\
$04 / 01 / 1913$ & 25.771 .552 & \\
$01 / 02 / 1913$ & 26.208 .784 & $1,70 \%$ \\
$01 / 03 / 1913$ & 26.648 .329 & $1,68 \%$ \\
$05 / 04 / 1913$ & 25.454 .918 & $-4,48 \%$ \\
$03 / 05 / 1913$ & 25.112 .890 & $-1,34 \%$ \\
$07 / 06 / 1913$ & 24.404 .574 & $-2,82 \%$ \\
$05 / 07 / 1913$ & 23.258 .511 & $-4,70 \%$ \\
$08 / 08 / 1913$ & 20.621 .152 & $-11,34 \%$ \\
$06 / 09 / 1913$ & 20.194 .357 & $-2,07 \%$ \\
$04 / 10 / 1913$ & 19.663 .635 & $-2,63 \%$ \\
$01 / 11 / 1913$ & 18.877 .940 & $-4,00 \%$ \\
$27 / 12 / 1913$ & 18.433 .592 & $-2,35 \%$ \\
\hline
\end{tabular}

Fonte: The Brazilian Review, diversas semanas durante o ano de 1913.

Os problemas de 1913 não deram trégua e a Caixa já começou o fatídico ano de 1914 com retiradas em ritmo constante, mas com picos de desespero, como indica a Tabela 2.6 para o mês de abril e de julho. A situação foi piorando e o acompanhamento do mercado dava sinais que o pior se aproximava, que uma moratória geral estava nos planos do governo e que somente a consolidação da dívida externa, arquitetada pelos Rothschilds em Londres, poderia amenizar a crise. Foi o que aconteceu no início de agosto. Restava, neste ponto, aceitar a forte pressão internacional e tomar o fatídico empréstimo. A aprovação pelo Congresso foi muito melhor que o imaginado e, por 102 votos contra 20, foram aprovadas medidas que permitiriam ao presidente Hermes da Fonseca liberdade nunca antes obtida por outros mandatários no Brasil. Isto foi uma demonstração inequívoca da sensação de urgência e do clima de calamidade contaminavam a todos. O que não se esperava era que a guerra 
começasse $\operatorname{logo}$ ao final de julho, jogando por terra meses de tratativas. ${ }^{107}$ A crise provocada pela falta de ouro se acentuou com o fim das negociações com os banqueiros e o governo foi obrigado a declarar moratória no dia 3 de agosto de 1914 por meio do decreto 11.036. A estrutura montada para a Caixa não poderia, como previsto, continuar funcionando quando a tendência de valorização da libra se consolidasse.

As principais medidas anunciadas foram o fechamento dos bancos até o dia 15 de agosto; suspensão por 30 dias, prorrogáveis por até 120 dias, do direito de execução de promissórias ou qualquer outra forma de contrato comercial; suspensão da troca por ouro da Caixa de Conversão, com a especificação de que o ouro restante poderia ser usado para honrar garantias assumidas no estatuto de 08 de dezembro de 1906. Além disto, a moratória para os bancos nacionais e estrangeiros cessaria apenas no momento no qual estas instituições recebessem assistência financeira do Estado por meio de emissão de moeda ou mecanismo equivalente $^{108}$. A economia brasileira, de forma inusitada, entraria em nova fase a partir de agosto de 1914, fase esta com novos protagonistas e novos desafios que exigiram mudanças radicais na política econômica nacional.

Conclusão.

As tentativas de diversificação da arrecadação federal resultaram em medidas que não se sustentaram após a normalização da economia internacional. O Brasil dependia em grande medida das rendas aduaneiras. Isto era um grave problema para a política econômica porque mantinha a economia brasileira reflexa da economia internacional. Tributos como o imposto sobre o consumo foram suficientes para cobrir uma parte da necessidade do orçamento em papel, mas o orçamento em ouro ficou descoberto. Isto pressionou o governo a buscar ajuda no sistema financeiro internacional.

Como o momento era de restrição nas principais praças financeiras da Europa, o governo brasileiro acelerou os investimentos em ferrovias porque esta era uma maneira de atender duas demandas de uma só vez: expansão logística e acesso a divisas. Os contratos para expansão da malha férrea brasileira eram firmados com empresas estrangeiras que

107 'Proposed Fresh Loan for Brazil - project has been duly sanctioned by Congress', julho 1914, FO 371/1916/32357, p. 150-1

108 'Mostly About Coffee', 11 agosto de 1914, p. 130 e 'Mostly About Coffee', 18 de agosto 1914, p. 136. 
traziam para o Brasil moeda conversível. O problema foi que estes investimentos aumentaram a dívida externa e pressionaram o governo no conta de remessa de lucros.

A situação de crise no Brasil era interpretada pelo governo britânico como oportunidade de manter negócios com o país, afastando interesses dos Estados Unidos e da Alemanha, principalmente. Isto permitiu ao Brasil algum tipo de diálogo com sistema financeiro internacional. Neste diálogo, foram negociadas exportações de sacas de café. Estas exportações ajudaram no acesso aos recursos em ouro, mas não foram suficientes para manter as atividades da Caixa de Conversão que foi obrigada a para de emitir notas conversíveis. Os depósitos em ouro da Caixa diminuíram rapidamente, provocando instabilidade no mercado de câmbio.

A Caixa de Conversão, que conseguiu estabilizar o câmbio nos períodos de fluxo positivo de moeda estrangeira, não pode repetir o desempenho quando o ouro se tornou escasso. A instituição que havia mantido o Brasil no padrão-ouro cessou as emissões de notas conversíveis antes do início da Primeira Guerra Mundial. O câmbio passou a oscilar e a incomodar o setor importador que era a origem dos recursos que financiavam o orçamento público.

Neste cenário negativo, o Brasil foi obrigado a buscar a renegociação da dívida externa no que ficou conhecido como segundo funding loan. Fato surpreendente foi que esta consolidação da dívida externa brasileira acabou ocorrendo por pressão do governo britânico. O motivo não era ajudar o Brasil, mas liquidar pendências comerciais que o Brasil tinha em moeda conversível com empresas britânicas. Os processos contra o governo brasileiro exigindo remessa de ouro para a Europa se avolumaram e deixaram o Brasil sem saída. O contrato de empréstimo tinha que ser assinado para permitir a regularização destas pendências comerciais e financeiras com o capital internacional.

A crise internacional e as incertezas quanto ao alastramento das guerras balcânicas dificultaram em muito a assinatura do funding loan. O processo foi lento e causou muita apreensão e expectativa na economia brasileira, assunto que será discutido no próximo capítulo. 


\section{Parte II - A economia brasileira durante a guerra: o custo da neutralidade}

\section{Capítulo 3 - A economia brasileira à espera dos recursos do funding loan}

O contrato do funding loan deveria ter sido assinado ainda no início de 1914, mas s incertezas na economia internacional forçaram o Tesouro Britânico a reexaminar o processo por diversas vezes. Os representantes brasileiros eram convocados para discutir garantias e o destino dos recursos que estavam em negociação. A exigência do Reino Unido era para que a quase totalidade do valor do contrato fosse utilizada de maneira vinculada. Isto significava que o governo brasileiro não poderia destinar estes recursos de acordo com as necessidades do país. Este vínculo na destinação dos recursos significava colocar no contrato os muitos credores do Brasil que haviam sido selecionados pelo Tesouro Britânico, liderado por John Maynard Keynes. Keynes se envolveu pessoalmente no funding brasileiro, exigindo condições que o governo brasileira entendia como inaceitáveis e ameaçando abandonar a mesa de negociações.

Este processo de seleção de credores e de discussão de cláusulas com o Ministério da Fazenda do Brasil levou meses para se encerrar. Esta demora provocou muitas incertezas na economia brasileira porque praticamente tudo passou a depender da entrada das divisas que estavam sendo negociadas. Os jornais relatavam o compasso de espera da atividade econômica no Brasil e culpavam o Reino Unido e o governo brasileiro pelos problemas que o país estava enfrentando.

Como resposta à sociedade brasileira, o governo voltou a autorizar a emissão de moeda em curso forçado. Esta mudança na condução da economia brasileira gerou muita polêmica entre os papelistas e os metalistas. Ainda havia no Brasil esperança por parte dos metalistas que o câmbio voltasse à taxa de 27 d., resgatando cotação da época do Império. O problema, diziam os papelistas, era que a insistência na busca desta cotação levaria o Brasil ao caos social. Daí a necessidade de emissão sem lastro, como veio a ocorrer. 
O início da Primeira Guerra Mundial adiou ainda mais a assinatura do contrato de empréstimo. Durante esta espera, a sociedade brasileira discutiu a validade em manter o Brasil ligado ao Reino Unido. Com a guerra, foi aberta a possibilidade de estreitar os laços com o Império Alemão. Isto atenderia a demanda do setor exportador que era dependente do capital alemão para a negociação de grande parte da safra de café. O porto de Hamburgo era referência para o mercado internacional de café internacional. Lá se concentravam as atividades da empresa Theodor Wille, importante agente para os cafeicultores brasileiros. Com a guerra, o café brasileiro estocado em Hamburgo ficou inacessível. A retenção destes recursos na Alemanha, a dificuldade na liberação das divisas do funding loan e os arranjos na economia brasileira para atravessar este período serão discutidos neste capítulo.

\section{Seção 3.1 - O processo de negociação do funding loan}

O desafio inicial que a Primeira Guerra Mundial colocou para a economia brasileira foi o adiamento para o segundo semestre de 1914 da assinatura do contrato do funding loan que vinha sendo construído desde 1913 entre autoridades brasileiras e os Rothschild, banqueiros com sede em Londres que centralizaram os interesses dos bancos internacionais credores do Brasil neste segundo processo de consolidação da dívida externa brasileira. ${ }^{109} \mathrm{O}$ cenário econômico internacional em 1914 era radicalmente distinto daquele de 1898 quando foi firmado o primeiro funding porque ao final do século XIX havia abundância de ouro e as taxas de juros eram expressivamente menores que em $1914 .{ }^{110}$

Este atraso na finalização do funding de 1914 ocorreu porque os primeiros meses do conflito mundial foram utilizados pelas potências europeias para a montagem da estrutura de exceção econômica que passou a direcionar as prioridades financeiras daquele continente ao entesouramento de ouro para fazer face às exigências da guerra. Mudanças econômicas nas principais praças financeiras da Europa, o epicentro da globalização, causavam importantes consequências colaterais em países como o Brasil. Os efeitos das mudanças econômicas nos países centrais deixaram ainda mais crítico o complexo cenário macroeconômico nacional, essencialmente dependente da economia internacional.

\footnotetext{
${ }^{109}$ Para detalhamento dos dois funding loans firmados pelo Brasil, ver Abreu, Os Funding Loans Brasileiros $1898-1931$.

${ }^{110}$ Calógeras, Formação Histórica do Brasil, p. 374-5.
} 
Os países protagonistas da primeira fase da guerra foram os mesmos envolvidos direta ou indiretamente nas guerras balcânicas - França, Reino Unido, Império Alemão, Império Austro-Húngaro, Império Russo e Império Turco-Otomano. A diferença era que agora, no início do segundo semestre de 1914, a estratégia de expansão alemã se mostrou sem subterfúgios. Tanto a possibilidade de herdar oficialmente os territórios sob domínio do Império Austro-Húngaro quanto a de ocupar a porção europeia do Império Russo transformaram os assassinatos do arquiduque Francisco Ferdinando, primeiro na linha de sucessória ao trono dos Habsburgos, e de Sophia Chotek, Duquesa de Hohenberg, no fato que levou às declarações de guerra na Europa a partir do final de julho de 1914. A Figura 3.1 resume as datas formais do início da conflagração entre os principais países envolvidos.

Figura 3.1 - Datas das declarações de guerra - fase inicial da Primeira Guerra Mundial, 1914-5

\begin{tabular}{lllll} 
Países & Sérvia & Império Britânico & França & Império Russo \\
\hline Imp. Austro-Húngaro & $28 / 07 / 1914$ & $12 / 08 / 1914$ & $12 / 08 / 1914$ & $06 / 08 / 1914$ \\
Império Alemão & $06 / 08 / 1914$ & $04 / 08 / 1914$ & $03 / 08 / 1914$ & $01 / 08 / 1914$ \\
Império Otomano & $02 / 11 / 1914$ & $05 / 11 / 1914$ & $05 / 11 / 1914$ & $01 / 11 / 1914$ \\
Reino da Bulgária & $14 / 10 / 1915$ & $15 / 10 / 1915$ & $16 / 10 / 1915$ & $19 / 10 / 1915$ \\
\hline
\end{tabular}

Fonte: Welt - Deutschland, Chronologie der Erste Weltkrieg.

À exceção do Reino da Bulgária, que conseguiu por motivos intrínsecos permaneceu neutro durante os primeiros meses da guerra, os países da formação original da Tríplice Entente - Reino da Sérvia, Império Britânico, França e Império Russo - e os que se uniram na Tríplice Aliança - Império Austro-Húngaro, Império Alemão e Império Otomano - fizeram declarações de guerra mútuas ainda durante o segundo semestre de 1914. Esses atos refletiam o clima de tensão que havia se instalado na Europa Ocidental e nos Estados Balcânicos desde 1912 quando alianças geopolíticas foram estabelecidas entre as maiores forças da região visando a um rearranjo de poderes que já era previsto desde a Guerra Franco-Prussiana (18701). Não foi por outro motivo que o atentado de Sarajevo provocou intensas e sumárias ações diplomáticas. As negociações que uniram interesses comuns já tinham sido concretizadas e os Estados estavam prontos para a confrontação bélica faltando apenas um marco que justificasse a ruptura da ordem na Europa. A nova orquestração de poderes teve força 
inusitada e bastaram apenas dois meses para que o cenário da Belle Époque fosse radicalmente alterado. ${ }^{111}$

Alianças militares demandam concentração de divisas - ouro era o sinônimo mais empregado no período - e foi esta a tarefa precípua da área econômica dos países da Tríplice Entente, os maiores credores e financiadores da economia internacional e que grande influência tinham sobre o Brasil. Se as guerras balcânicas provocaram uma das maiores crises que a economia brasileira já havia experimentado, era de se imaginar que sem mudanças macroeconômicas estruturais o país seria mais duramente atingido agora neste cenário de confronto mundial que se iniciou em agosto de 1914. As alterações advindas com a guerra ficaram em segundo plano na escala de prioridades do governo brasileiro porque a grande questão que carecia de solução e que tanta apreensão provocava no mercado interno era a liberação dos recursos do funding loan, medida econômica entendida como uma panaceia para a crise dos negócios internacionais do Brasil e de seus efeitos sobre a o mercado doméstico.

A situação econômica nacional vinha sendo marcada por crise desde o final de 1912 . Esta crise transformou-se em desastre para os negócios em 1913 quando nada parecia indicar conjuntura pior, até os meses que antecederam a liberação do funding loan e a certeza de alívio financeiro por meio de recursos externos na forma de um empréstimo consolidado deu lugar ao mais completo ceticismo. O assassinato do herdeiro do trono dos Habsburgos em junho condensou os problemas para o Brasil em dois blocos de adversidades que foram responsáveis por reverter as expectativas positivas com as quais os agentes econômicos estavam trabalhando desde o fim das guerras balcânicas:

1) A guerra modificaria, já no início do segundo semestre de 1914 , o comércio exterior brasileiro ao restringir o acesso à navegação comercial marítima internacional e ao considerar o cacau e o café, principais produtos de exportação do país, suscetíveis a ações de contrabando para os países da Tríplice Aliança. O financiamento do setor público ficou ainda mais comprometido pela redução na arrecadação de tributos aduaneiros e em virtude da diminuição na geração de renda interna dada a retração na entrada de cambiais das exportações. O café foi exportado durante a guerra, mas em condições atípicas tanto para os empresários ligados ao setor quanto para o governo. A

\footnotetext{
${ }^{111}$ Para as impressões de um jornalista e autor brasileiro sobre o fim da Belle Époque, ver Mesquita, "O mundo antes e depois da guerra", in A guerra (1914-1918), p. 74-80. Mesquita foi correspondente na Europa do $O$ Estado de S. Paulo durante a Primeira Guerra Mundial.
} 
arrecadação prosseguiu durante a guerra apesar das reduções sofridas, mas com caraterísticas distintas devido a adaptação à nova economia internacional.

2) Os rearranjos diplomáticos e econômicos suscitados pelo início da guerra forçaram o adiamento da assinatura do contrato de consolidação da dívida externa brasileira. O funding loan foi o segundo contrato do tipo que o país necessitava realizar com os banqueiros internacionais em um acordo que liberaria recursos para que fosse possível honrar compromissos assumidos com o capital internacional, permitindo ao governo uma folga orçamentária que já se sabia seria momentânea. A guerra teve o papel de eliminar qualquer possibilidade de continuidade imediata das negociações e a economia brasileira entrou em modo de espera. Os compromissos com o mercado financeiro internacional definidos pelo funding não eram necessariamente os que mais interessavam ao país saldar, mas sim os que os credores internacionais conseguiram impor na agenda dos governos de seus países para negociação com o governo brasileiro. $^{112}$

Este estado das coisas paralisou o governo Hermes da Fonseca que, em termos práticos, acabou bem antes de novembro de 1918 devido à falta de recursos para compromissos externos e internos. As exportações eram a principal fonte dos recursos em ouro e padeciam desde o início de 1913 com a redução nos preços do café e da borracha, produtos que representavam $85 \%$ da pauta brasileira. A situação ganharia contornos ainda mais dramáticos com a conflagração mundial e modificações de toda ordem ocorreriam no status quo do comércio exterior brasileiro: alterações na política de financiamento internacional, na logística, na exclusão das parcerias comerciais com a Alemanha, Áustria, Bélgica e Rússia, e nas condições para a venda dos estoques, sobretudo de café. ${ }^{113}$ Como as exportações forneciam as cambiais necessárias às importações, a aquisição de bens do exterior também passou por limitações, o que sobrecarregou o déficit orçamentário. Se estes fossem os únicos fatores negativos a considerar os entraves econômicos já seriam de grande vulto, mas devem ser computados ainda os efeitos do estrangulamento externo sobre o comércio interno causado pela natural retração nos pedidos aos fornecedores.

Com volume e valores importados menores, a renda aduaneira que era a fonte predominante de receitas em ouro e em papel apresentou resultados bastante inferiores a

\footnotetext{
${ }^{112}$ Para o contexto da economia brasileira no período imediatamente anterior à Primeira Guerra Mundial, ver Fritsch, "Aspectos da política econômica no Brasil, 1906-1914”, p.257-315.

${ }^{113}$ Bueno, Política externa da Primeira República - Os anos do apogeu, p. 472.
} 
1913. No primeiro semestre de 1914, a redução nas importações foi de cerca de $30 \%$ em comparação ao ano anterior, resultado que fez decrescer a renda aduaneira, ampliando ainda mais as esperanças em uma recuperação do setor externo por intermédio da retomada nos preços do café. Até o final do ano as importações seriam ainda mais limitadas por causa da guerra e registrariam valores em torno de $66 \%$ inferiores a $1913 .{ }^{114}$ No início do segundo semestre e já em ambiente inebriado pelo conflito mundial, os anseios por um cenário melhor não podiam ir além da data na qual os recursos em moeda forte do funding loan seriam finalmente liberados.

\section{Seção 3.2 - Os motivos para o funding loan}

As negociações para o novo empréstimo consolidador da dívida externa brasileira foram longas, com muitos contratempos e alimentadas por pressões internas e externas que se alteraram radicalmente a partir da constatação que o assassinato do Arquiduque Francisco Fernando em Sarajevo não ficaria restrito a um revide militar do Império Austro-Húngaro nos Bálcãs. Com base nesta nova perspectiva internacional, as principais potências europeias teriam que rever suas políticas externas, singularmente as que envolvessem desembolso de divisas no médio ou no longo prazo para que fosse possível suportar o jogo de poderes entre os Estados que era caraterizado por um elevado grau de desconhecimento sobre as forças efetivas que cada país possuía. Estas nações que contavam com desenvolvimento econômico e social elevados e que se encontravam envolvidas em acordos militares de proteção mútua colocaram suas forças à disposição da guerra gerando muita riqueza. A questão que se coloca é que para gerar tanta riqueza foram necessários investimentos que exigiram concentração de renda nas mãos dos Estados. Foi o que ocorreu a partir do segundo semestre de 1914 quando os bancos europeus passaram a trabalhar voltados para as necessidades do Tesouro dos países nos quais tinham sede, notadamente Londres, Paris e Berlim. ${ }^{115}$

Apesar do cenário internacional de mudanças, o governo brasileiro passava a mensagem que o mercado deveria confiar que uma política econômica que buscasse o equilíbrio orçamentário poderia sanear as finanças do país em tempo relativamente curto. ${ }^{116} \mathrm{O}$ problema era muito maior porque envolvia questões negativas que afetavam a estrutura da economia brasileira, como orçamentos fictícios, déficits que ficavam em vários pontos acima

\footnotetext{
${ }^{114}$ Para dados sobre o comércio exterior brasileiro entre 1913 e 1914, ver: Mensagem apresentada ao Congresso Nacional - 1915, p. 96-103.

${ }^{115}$ Hamilton; Herwig, "On the origins of the catastrophe", The Origins of World War.

${ }^{116}$ Mensagem Presidencial ao Congresso Nacional - 1914, p. 164.
} 
do previsto e que necessitavam de financiamento em ouro, recursos aprisionados na Europa, dentre outros elementos.

A guerra e as restrições financeiras dela decorrentes agravaram a situação que parecia de solução muito difícil. Mesmo que um empréstimo desvinculado de liquidação de passivos fosse obtido pelo Brasil, em operação distinta do funding loan, o cenário não teria sido diferente porque o que importava essencialmente naquele momento era a manutenção de uma economia tipicamente primário-exportadora e que deixava quase nenhum espaço para a industrialização.

A instalação de indústrias durante a Primeira Guerra no Brasil pode até ter se consubstanciado em números de unidades fabris, operários e força motriz como consta na historiografia, mas neste período demonstra nem os agentes econômicos brasileiros nem os financiadores internacionais dedicaram atenção especial a um Brasil ativo no setor secundário. Apesar de longas e detalhadas avaliações sobre a economia brasileira, o Ministério das Relações Exteriores do Reino Unido não abordou o desenvolvimento industrial que teria se instalado no país durante a guerra. É factível argumentar que Londres não teria interesse natural em fábricas sendo instaladas em um mercado importador de manufaturados britânicos, mas o grau de detalhamento com o qual o Brasil foi analisado pela diplomacia e por especialistas em economia do governo britânico, como John Maynard Keynes, não teria deixado o tema sem abordagem se o movimento industrial tivesse sido algo transformador, algo que tivesse modificado a estrutura produtiva do país. ${ }^{117}$

No primeiro semestre de 1914, a City estava mesmo era interessada no funding loan brasileiro porque o contrato tinha implicações de longo prazo que colocavam em jogo a continuidade da preponderância do capital financeiro britânico no Brasil. As discussões sobre o empréstimo começaram com valor de $£ 11.000 .000$, juros de $5 \%$ e amortização de $1 \%$ a.a. Os banqueiros indicados pelo Tesouro do governo britânico foram N.M. Rothschild \& Sons que acertaram comissão de $4 \%$ sobre o capital nominal. ${ }^{118}$ Longe de ser considerado um

\footnotetext{
117 John Maynard Keynes foi funcionário do Tesouro britânico de 1907 até 1919, quando se desligou de suas funções por não concordar com a posição do governo britânico sobre as reparações de guerra que a Alemanha teria que arcar após a Primeira Guerra. Para o contexto, ver: Abreu, "John Maynard Keynes e as relações econômicas anglo-brasileiras durante a II Guerra Mundial", p. 36.

Sobre Keynes e o Brasil, escreveu Abreu: "Não há qualquer indício de que, no exercício destas funções, Keynes tenha tido interesse especial por assuntos brasileiros. As referências ao Brasil em sua obra publicada são esparsas, em geral sublinhando a crônica instabilidade econômica - financeira do Brasil, como, por exemplo, em seu memorando de 15.9.15 sobre The Meaning of Inflation.”, Ibidem, p. 37.

${ }^{118}$ Mensagem Presidencial ao Congresso Nacional - 1914, p. 166.
} 
monopólio, a participação desta casa bancária era entendida como estratégica pela chancelaria britânica porque a situação dos banqueiros do Rothschild no início da guerra não era mais de todo confortável como havia sido nas relações com o governo brasileiro ao longo de tantas décadas. Nesta década de 1910, banqueiros norte-americanos estavam especialmente interessados no lucrativo negócio que representava o café do Brasil, negócio complexo que envolvia o adiantamento do valor das vendas do produto com cobrança de taxas de juros mais que compensatórias. Este era um tipo de negócio permanente porque a possibilidade de emprestar recursos de maneira sistemática era muito elevada porquanto as finanças públicas do Brasil não operavam sem os recursos do sistema financeiro internacional.

O que provocou o segundo funding loan não foi a guerra, mas uma miríade de fatores que tiveram a crise de 1913 como ponto de tensão máximo aos quais foram somadas as contrações nos preços do café e da borracha e a exiguidade dos recursos em moeda conversível para fazer frente às despesas públicas que aumentavam sem controle efetivo do governo. Colocar a conflagração mundial como motivo para o funding loan seria correto apenas se os problemas financeiros do Brasil não tivessem começado bem antes de 1914 .

A guerra modificou completamente o fluxo do comércio exterior que no Brasil foi sentido na redução das exportações de café e na maior dificuldade para importar, as causas incluíam falhas na logística internacional provocada pelas carências no modal marítimo, e a retirada de fornecedores estrangeiros tradicionais sediados nos países da Aliança, especialmente empresas austríacas e alemãs que eram importantes para o suprimento de máquinas, equipamentos e produtos químicos em geral utilizados na indústria têxtil e na agricultura. Além de afetar diretamente a produção, a redução nas importações diminuiu a entrada de ouro que era obtido por meio da cobrança dos tributos aduaneiros e esta foi a principal razão para o aumento do déficit público, como pode ser observado na Tabela 3.1 a seguir.

Tabela 3.1- Receitas e despesas efetivas da União, 1913- 1919 (contos de réis)

\begin{tabular}{ccccc}
\hline Exercício & Receitas & \multicolumn{1}{c}{ Despesas } & Saldo ou Déficit & $\begin{array}{c}\text { Déficit } \\
(1913=\text { base 100) }\end{array}$ \\
\hline 1913 & 654.391 & 762.945 & -108.554 & 100 \\
1914 & 423.252 & 759.914 & -336.662 & 310 \\
1915 & 485.599 & 688.582 & -202.983 & 187 \\
1916 & 477.897 & 686.558 & -208.661 & 192 \\
1917 & 537.441 & 801.447 & -264.006 & 243 \\
1918 & 618.830 & 867.162 & -248.332 & 229 \\
1919 & 625.693 & 931.579 & -305.886 & 282 \\
\hline
\end{tabular}


Fonte: Resumo de várias estatísticas econômico-financeiras. Diretoria Geral de Estatística Rio de Janeiro, 1924, p.131.

O descontrole dos gastos públicos, a dependência de receitas baseadas em tributos do setor externo da economia, a crise econômica de 1913 e a guerra estão espelhados na tabela acima. A guerra contribuiu para o aumento do déficit porque houve retração nas receitas de tal ordem que o total registrado para 1914 foi o mais baixo para o período selecionado. Como as despesas não acompanharam a retração apurada nas receitas, o déficit chegou a $210 \%$ acima do verificado para 1913. Foi o maior percentual até 1919, ano que deveria ter apresentado resultado financeiro melhor porque estavam encerradas as diversas e complexas restrições do War Trade Department (Departamento de Comércio da Guerra para o comércio internacional).

A necessidade de recursos em moeda forte no Brasil pode ser devidamente avaliada com base no comportamento do comércio exterior nacional para o ano de 1914. As exportações somaram $£ 46,8$ milhões resultando em redução de $28,49 \%$ sobre o total do ano anterior que fora um ano de forte crise internacional e que levou as exportações de café ao total de $£ 27$ milhões representando queda de $33 \%$. Isto ocorreu devido à queda no preço do produto no mercado internacional dado que a redução na quantidade foi expressivamente menor, algo como 15\% a menos de sacas de café exportadas. Em relação às importações, os problemas com os efeitos da guerra nos negócios levaram à retração de cerca de $50 \%$ nos valores internados, traduzindo com clareza a situação vivida pelo Brasil naquele momento. ${ }^{119}$

A renda aduaneira depende de divisas são originadas nas exportações, e estas praticamente dobraram após o fim da guerra. O problema foi que este fato positivo nas finanças públicas ficou diminuído frente aos gastos públicos que durante a guerra cresceram ainda mais. $\mathrm{O}$ descontrole nas contas públicas que já era problema nas primeiras décadas da Republica continuou sem solução após o fim da guerra. Passada a fase de restrições mais severas que a guerra impôs, era de se esperar fase menos crítica nas finanças públicas, mas não foi o que se passou no orçamento de 1920, por exemplo, publicado com déficit de aproximadamente $30 \%$ em mil-réis papel. ${ }^{120}$

Vale constatar que um dos efeitos da guerra no Brasil foi o de expandir os problemas que afligiam a economia nacional. O funding loan ou outra forma de repactuação da dívida

\footnotetext{
${ }^{119}$ IBGE, Repertório Estatístico do Brasil-Quadros Retrospectivos no 1, p. 68-76.

${ }^{120}$ Ministério da Fazenda, Orçamento da receita e despesa do exercício de 1920, p. VI.
} 
externa brasileira eram fundamentais, mesmo que a guerra não tivesse modificado as estruturas da economia internacional. A documentação é farta no que diz respeito às necessidades de recursos em ouro e à falta de opções do governo ainda em 1913 e no início de 1914. ${ }^{121}$ Os documentos indicam que a guerra parece não ter feito mais do que adiar a assinatura do contrato de consolidação da dívida externa.

As regras de financiamento internacional seriam modificadas com o advento da guerra porque as prioridades das potências da Entente que comandavam a economia internacional passaram a exigir de países como o Brasil, neutros e produtores de bens que permitiam o entesouramento e o contrabando, postura subserviente nos assuntos estratégicos da guerra. Como contrapartida, o sistema financeiro internacional acenava com leniência nas questões da economia nacional. Londres lograva assim atingir dois objetivos em relação ao Brasil: o afastamento das linhas de ação que o Império Alemão estava empreendendo na América do Sul, e recursos para financiar parte da guerra por meio das vendas de café e do pagamento do serviço da dívida externa. ${ }^{122}$

O detalhamento do funding loan assinado em 19 de outubro de 1914 ajuda no entendimento dos principais pontos do estrangulamento externo da economia brasileira à época da guerra: ${ }^{123}$

- O valor do contrato, $£ 15.000 .000$, foi destinado ao pagamento de juros de diversos empréstimos em aberto, ao pagamento dos títulos incluídos no acordo com os banqueiros em agosto de 1914, ao pagamento do empréstimo de 1911 no valor de $£ 9.300 .000$, ao pagamento de obras no porto do Rio de Janeiro no valor de $£ 117.700$ e às garantias para o pagamento de $£$ 2.500.000 em juros para empresas construtoras de estradas de ferro e de obras portuárias;

- Diversas pendências comerciais com empresas de capital francês, alemão e britânico foram atendidas no valor total de $£ 2.310 .932$. Este total envolveu negócios os mais diversos, como foi o caso da empresa Cory Brothers \& Co. O valor reivindicado pela empresa era de $£$ 274.187 relativo a contratos para o fornecimento de carvão e que por muito tempo muita discussão suscitou entre Londres e o Rio de Janeiro. ${ }^{124}$ Este caso é bastante ilustrativo dos bastidores das tratativas do funding loan porque a análise dos documentos do corpo

\footnotetext{
${ }^{121}$ Para orçamentos de 1913 e 1914, ver: Ministério da Fazenda, Balanço da receita e despesa da República no exercício de 1913; Ministério da Fazenda, Balanço da receita e despesa da República no exercício de 1914.

${ }^{122}$ Export of coffee from Brazil and Brazilian finance, 15 setembro 1916, FO 371/2640/183580.

${ }^{123}$ Mensagem Presidencial ao Congresso Nacional - 1915, p. 88.

${ }^{124}$ Mensagem Presidencial ao Congresso Nacional - 1915, p. 90.
} 
diplomático britânico deixa evidente como algumas empresas tinham trânsito bastante livre junto aos poderes públicos, no Reino Unido e no Brasil. A Cory Brothers \& Co. conseguiu movimentar uma quantidade tão elevada de correspondências entre os diversos órgãos do governo britânico que foram criadas para ela pastas específicas no Ministério das Relações Exteriores do Reino Unido. Essas pastas receberam atualizações constantes nas quais as observações dos proprietários da empresa eram tratadas como se tivessem sido originadas em algum gabinete interno britânico. A força desta empresa vinha não apenas dos números globais de vendas ela apresentava, mas ainda pelo tipo de produto que comercializava, carvão em pedra de alta qualidade, insumo fundamental para a produção industrial, para a logística navios, trens -, sem contar a aplicação bélica que agora se impunha. ${ }^{125}$

- Suspensão do pagamento de juros até 1917, com exceção dos juros sobre o funding loan de 1898 e dos recursos obtidos em 1903 para as obras do porto do Rio de Janeiro;

- Suspensão das amortizações dos empréstimos até 1927, com exceção do funding de 1898;

- Amortizações previstas: títulos de 5\% do funding em total equivalente ao saldo verificado anualmente e proveniente da diferença entre a importância das garantias do governo em relação às estradas de ferro, bem como as somas arrecadadas por arrendamento ou cessão das estradas de ferro. Estes títulos do funding poderiam ser vendidos no mercado pelo Rothschild - como realmente ocorreu em 1919 no valor de $£ 1.316 .640$ - e o resultado da venda aplicado na compra de títulos de rescisão das garantias ferroviárias de $1901 .^{126}$

Quando a estas informações são adicionados os dados da dívida externa da União de 1913 fica patente que o problema da economia brasileira somente poderia ser solucionado por meio de uma repactuação dos compromissos externos. Em 31 de dezembro daquele ano o total consolidado foi de $£ 103.772 .780$, já computados os $£ 11.000$ milhões relacionados ao empréstimo autorizado pelo Congresso em abril de 1913 para a construção de portos e ferrovias, operação que se tornou comum na política econômica brasileira e que foi de grande utilidade para amenizar a carência de ouro no curto prazo. ${ }^{127}$

O total da dívida externa representava mais que o dobro das exportações daquele ano, indicativo da necessidade de algum arranjo especial com os banqueiros estrangeiros. As necessidades de recursos em ouro não davam sinal de diminuição, como comprova o

\footnotetext{
${ }^{125}$ Brazilian loan \& Cory Brothers claim versus Brazil, 25 junho 1914, FO 371/1916/28620.

${ }^{126}$ Relatório do Ministério dos Negócios da Fazenda - 1914, p. 57.

${ }^{127}$ Decreto 10.197 de 29 de abril de 1913.
} 
empréstimo contraído pelo estado de São Paulo em 1914 no valor de $£ 4.200 .000$ que teve como garantia 3.200.000 sacas de café estocadas em diversos pontos da Europa em valor de mercado estimado em $£ 9.000 .000 .{ }^{128}$ Este modelo de garantir empréstimos com sacas de café que eram transferidas para os mercados consumidores europeus foi o grande motivo de o Brasil ter sido obrigado a negociar em fóruns internacionais a liberação de estoques de café que se encontravam em portos do Império Alemão - a maioria em Hamburgo - quando estourou a guerra.

Ainda em 1914, houve empréstimos e investimentos em ferrovias que totalizaram $£$ 3.726.100, com a fatia mais expressiva destinada à Companhia Mogiana e à Cia. Leopoldina Railway. ${ }^{129}$ Obter recursos em ouro com a malha ferroviária como garantia acabaria por se tornar uma das razões para o descontrole da dívida externa e para as recorrentes renegociações dos compromissos internacionais brasileiros. Era uma maneira eficaz de o país conseguir financiar o déficit público porque que até o início da guerra houve capital internacional disponível e interessado na rentabilidade que investimentos em ferrovias no Brasil proporcionavam, tanto pelo pagamento da taxa de juros, quanto pelo recebimento das tarifas ferroviárias nos trechos de maior fluxo de carga.

O ponto inicial do processo que levou ao funding loan pode ser localizado no início do segundo semestre de 1913, quando o governo se deparou com a falta de alternativas para o financiamento de compromissos em ouro. O empréstimo de $£ 11$ milhões já fora incorporado, a Caixa de Conversão estava emitindo sinais claros que havia chegado o tempo da desvalorização do mil-réis e a balança comercial acabaria por fechar o ano com déficit absolutamente fora do comum. As formas usuais para o financiamento do setor externo da economia brasileira pareciam esgotadas, restando apenas a possibilidade de solicitação de mais um empréstimo, desde que fosse uma operação não vinculada e que permitisse liberdade de gastos ao governo. Contas feitas, o Ministério da Fazendo chegou à conclusão que seriam necessários $£ 14$ milhões para fechar o orçamento de 1913, dos quais $£ 10$ milhões teriam que vir na forma de empréstimo externo. O Congresso negou autorização para a tentativa de incluir o empréstimo externo no orçamento e o governo foi obrigado a utilizar a prerrogativa

\footnotetext{
${ }^{128}$ Relatório do Ministério dos Negócios da Fazenda - 1914, p. 104.

${ }^{129}$ Relatório do Ministério dos Negócios da Fazenda - 1914, p. 104.
} 
dos empréstimos internos e das letras do Tesouro para financiar o déficit, medidas paliativas de curtíssimo prazo. ${ }^{130}$

Além das sempre complexas negociações com o Congresso, o maior problema para a obtenção de recursos externos era que os valores negociados tinham destino fixado no contrato com os banqueiros internacionais. A exceção eram os empréstimos em valores mais baixos destinados a cobrir os déficits orçamentários, mas até mesmo estes não eram totalmente desvinculados das soluções para pendências comerciais com empresas de capital estrangeiro. Uma das possibilidades para a entrada de divisas e para a obtenção de financiamento interno foram os investimentos em ferrovias e portos. O valor para a importação de equipamentos e máquinas destinadas aos empreendimentos de infraestrutura era obtido no exterior, financiava o orçamento em ouro e gerava renda aduaneira com as importações do equipamento principal e com as aquisições regulares de partes e peças. Análise da dívida externa brasileira até junho de 1913 demonstrada na Tabela 3.2 identifica quão prioritárias foram estas obras para a política econômica, e como sucessivos governos desde o início da República ficaram dependentes deste artifício para que o país tivesse condições mínimas de governabilidade.

Tabela 3.2 - Dívida externa do Brasil, 1889- outubro 1913 (libras esterlinas)

\begin{tabular}{|c|c|c|}
\hline Ano & Objetivo & Capital Nominal \\
\hline 1893 & $\begin{array}{l}\text { Ferrovia Oeste de Minas } \\
\text { (segunda emissão de títulos) }\end{array}$ & 3.710 .000 \\
\hline 1895 & Financiamento de déficit & 7.442 .000 \\
\hline 1898 & Funding loan & 8.613 .717 \\
\hline 1901 & Rescisão de garantias - ferrovias & 16.619 .320 \\
\hline 1903 & Porto do Rio de Janeiro - obras & 8.500 .000 \\
\hline 1907 & Empréstimo para Café - São Paulo & 3.000 .000 \\
\hline 1908 & Porto do Rio de Janeiro - obras & 4.000 .000 \\
\hline 1908 & $\begin{array}{l}\text { Ferrovia Itapura-Corumbá } \\
\text { (empréstimo francês) }\end{array}$ & 4.000 .000 \\
\hline 1909 & $\begin{array}{l}\text { Porto de Pernambuco } \\
\text { (empréstimo francês) }\end{array}$ & 1.600 .000 \\
\hline 1910 & $\begin{array}{l}\text { Ferrovias no Ceará e conversões } \\
\text { dos nrs. } 4 \text { e } 9\end{array}$ & 10.000 .000 \\
\hline 1910 & $\begin{array}{l}\text { Ferrovia de Goiás } \\
\text { (empréstimo francês) }\end{array}$ & 4.000 .000 \\
\hline 1911 & Ferrovias da Bahia & \\
\hline
\end{tabular}

${ }^{130}$ Brazil-Annual Report, 1913 - The Financial Crisis of 1913, 15 janeiro 1915, FO 371/1915/5814, p.13. 


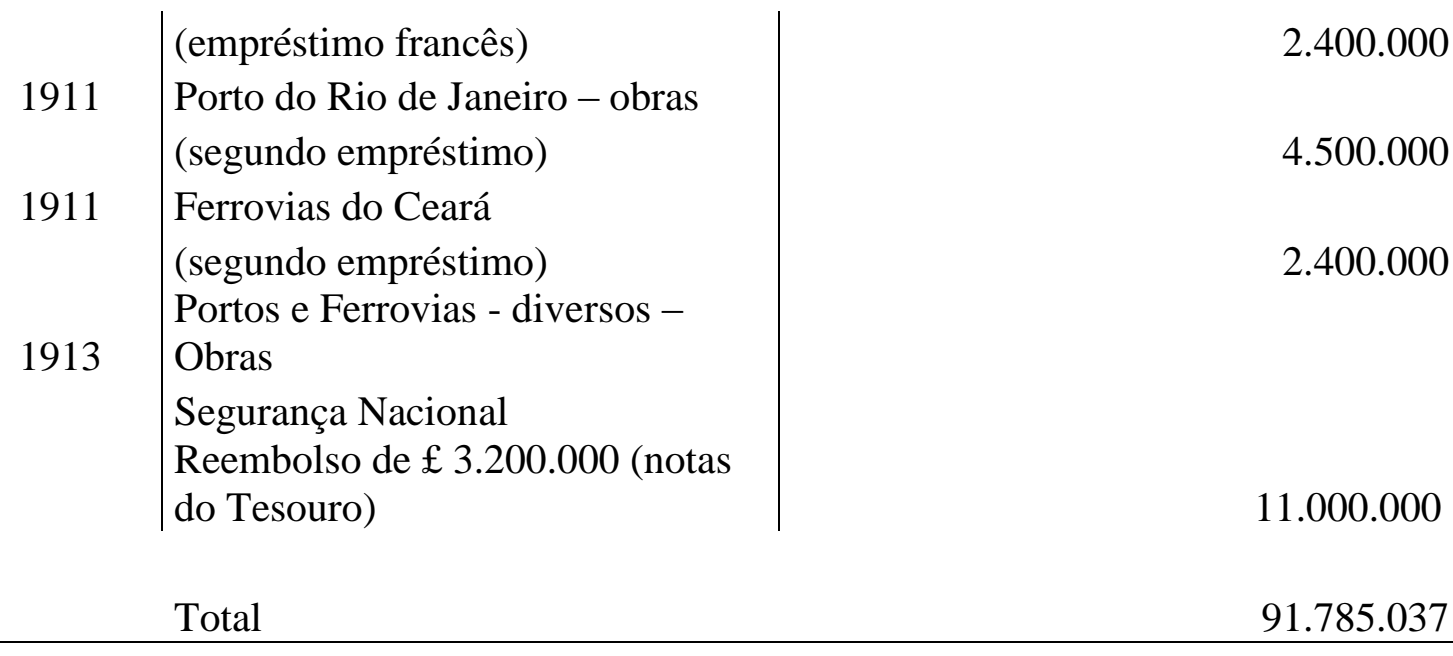

Fonte: Brazil - Annual Report, 1913 - External Debt of Brazil, 15 janeiro 1915, FO 371/1915/5814, p.14.

Dos quinze lançamentos em dívida externa desde a Proclamação da República, apenas três não tiveram relação direta com obras em ferrovias e portos. Esta preponderância da infraestrutura para a dívida externa colaborou para o desenvolvimento da logística do país e ainda ajudou o governo a conseguir acesso aos recursos do sistema financeiro internacional.

Pode ser notado na Tabela 3.3 que houve interesse do capital internacional em participar de obras que não estavam localizadas em praças com elevadas garantias de rentabilidade, como Goiás ou Ceará. Tal fato indica que empreendimentos que não eram tão lucrativos como os da região Sudeste conseguiram captar recursos antes da guerra.

A insuficiência de recursos em ouro nos moldes pleiteados pelo governo fez com que o Ministério da Fazenda obtivesse as autorizações necessárias para solicitar a emissão de papel moeda no total de 250.000 contos. Dessa soma, 150.000 contos serviriam para cobrir passivos do Tesouro e 100.000 contos para ajudar no financiamento dos bancos que atuavam no Brasil, incluindo três bancos brasileiros com sede no Rio Grande Sul e o Brasilianische Bank für Deutschland. Interessante notar que esta operação ocorreu em agosto de 1914, antes da assinatura do contrato do novo funding. ${ }^{131}$

O estranhamento com o fato de constar da relação de bancos auxiliados uma instituição com capital alemão se desfaz quando se tem acesso às regras para os repasses. Uma delas estipulava que o banco recebedor do auxílio se comprometesse a praticar no mercado a taxa cambial valorizada utilizada pelo Banco do Brasil. O problema é que eram

${ }^{131}$ Brazil - Depreciation of Currency, 03 outubro 1914, Treasury 1/11865/ 21006, Carta emitida por Jacob Walter \& Co. em 16 outubro 1914. 
tempos de desvalorização do mil-réis, e apenas bancos com sede em um país com baixa liquidez, situação enfrentada pela Alemanha, se sujeitavam a aceitar tal imposição. Diante destas condições, os bancos britânicos foram obrigados pelo Tesouro do Reino Unido a recusar a ajuda do governo federal brasileiro. Havia defasagem cambial praticada na época pelo Banco do Brasil, como se pode verificar quando o câmbio chegou a ser negociado a 16 d., algo como 30\% abaixo da cotação praticada no mercado. Para o governo britânico, esta intrincada operação era fruto de pressão da Fazenda sobre o Banco do Brasil e continha riscos elevados de insucesso. A ausência dos banqueiros britânicos acabou afastando a quase totalidade dos bancos estrangeiros desta operação de ajuda aos bancos comerciais que operavam no Brasil patrocinada pelo governo. ${ }^{132}$

A falta de recursos vivenciada pelos bancos dificultava em muito o financiamento do comércio e da indústria, motivo de muita discussão entre os bancos britânicos que atuavam no Brasil e a diplomacia britânica. A comparação com as possibilidades de acesso à liquidez que empresas alemãs tinham no Brasil era inevitável e de certo modo incompatível com situação que a Alemanha estava enfrentando no comércio internacional. Os recursos repassados pelo Tesouro Brasileiro ao Brasilianische Bank für Deutschland foram o grande diferencial para que empresas alemãs conseguissem colocar café brasileiro em portos europeus, privilégio mais do que especial durante a guerra e que acabou convencendo empresas britânicas a participar desta triangulação e aparentemente sem lógica: recursos brasileiros sem lastro financiaram um banco do Império Alemão que financiaria uma empresa britânica no Brasil na exportação de café para a Europa. Vale lembrar que a esta altura do calendário - outubro de 1914 - o Reino Unido e o Império Alemão estavam oficialmente em guerra há quase três meses, comprovação de como negócios entre países inimigos conseguiram ultrapassar barreiras impostas pelos governos durante a fase inicial dos conflitos. ${ }^{133}$

Pouco tempo após a controversa liberação de moeda sem lastro para os bancos, houve nova autorização para mais um curso forçado de 150.000 contos, sendo dois terços destinados aos bancos selecionados pelo Ministério da Fazenda e pelo Banco do Brasil, e um terço para financiar o Tesouro Nacional. O governo de Hermes da Fonseca, já nos seus estertores, abandonara por completo qualquer plano de austeridade monetária, afastando-se formalmente da política econômica de Murtinho e da ortodoxia que ainda pairava sobre a política

\footnotetext{
${ }^{132}$ Brazil - Depreciation of Currency, 03 outubro 1914, Treasury 1/11865/ 21006, 16 outubro 1914.

${ }^{133}$ Brazil - Depreciation of Currency, 03 outubro 1914, T1/11865/ 21006, carta emitida por Jacob Walter \& Co., 27 outubro 1914.
} 
monetária do país. Durante a guerra, o tema disciplina fiscal ficaria reservado para a retórica que governo e parlamentares empregavam quando das discussões sobre o orçamento no Congresso. $^{134}$

Diante da insuficiência de recursos e frente aos impasses que impediam a liberação do funding loan, o governo brasileiro fez ouvidos moucos às vozes do mercado contrárias ao papelismo e cedeu aos apelos do comércio e bancos que muita pressão vinha fazendo por liquidez. Era como se a guerra tivesse dado ao governo a liberdade para praticar políticas não convencionais que em tempos de paz teria recebido duras reprimendas e ameaças diretas do governo Britânico.

As emissões sem lastro não ficariam, porém, sem manifestações de descontentamento por parte do establishment financeiro. Sérias preocupações foram manifestas pelos banqueiros internacionais porque a desvalorização do mil-réis se mostrou implacável com o súbito aumento de moeda sem lastro que estava entrando na economia e que estava provocando a queda da cotação da moeda nacional frente à libra esterlina de 16 d. para 13 d., acendendo alertas nas praças financeiras de Londres, Paris e Nova York. Os banqueiros britânicos, por exemplo, foram orientados pela chancelaria britânica a aceitar qualquer oferta de pagamento de dívida feita pelo Brasil porque a situação financeira do país havia piorado em tal ordem que todos os credores deveriam fazer uso da máxima que diz que "metade de um pão é melhor do que nada" [half a loaf is better than no bread]. Isto valia para o Tesouro Britânico e para empresas privadas que porventura tivessem recursos represados no Brasil na forma de retorno sobre investimentos ou de contenciosos comerciais. ${ }^{135}$

A demora na liberação do novo empréstimo fez surgir no mercado brasileiro explicações as mais variadas com base em fatos ou meras especulações. Uma das interpretações foi a que versou sobre a indisposição dos banqueiros europeus em liberar os recursos enquanto o Congresso Brasileiro não fornecesse provas concretas que estava determinado a abandonar a imprudência e a extravagância no trato com o dinheiro público. A origem desta explicação para a delonga na assinatura do contrato do funding loan foi um artigo no jornal The Times que abordou as mazelas da economia brasileira e vaticinou que os problemas no país perdurariam se não fosse adotado um estrito regime de cerceamento dos gastos públicos. Como o artigo acabou por ser traduzido e publicado no Brasil, o alcance das

${ }^{134}$ Brazil - Depreciation of Currency, 03 outubro 1914, T1/11865/ 21006, carta emitida por Arnold Peterson em 01 setembro de 1914.

${ }^{135}$ Brazil-Depreciation of Currency, 03 outubro 1914, T1/11865/ 21006, p. 1-3. 
críticas do jornal londrino foi muito além do que seria de se esperar e acabou movimentando a opinião pública nacional em busca de solução para as críticas feitas. ${ }^{136}$

No Congresso, decidiu-se criar o Comitê de Finanças com o objetivo de encontrar saídas para melhorar a qualidade do gasto público. As sugestões do grupo de deputados que participou desta comissão incluíram a extinção de departamentos e de cargos públicos, mas o ponto de maior discussão foi o Comitê ter mencionado a necessidade de um exemplo contumaz de austeridade à sociedade, e nada poderia ter maior impacto do que falar em cortar $25 \%$ os salários dos servidores, excetuando-se os que recebessem até Rs. $250 \$ 000$ por mês, pouco mais de $£ 16$. A reação a esta possibilidade foi das mais ruidosas. Um grupo de funcionários chegou a exigir medidas por parte do governo que garantissem e que salvaguardassem os proventos dos servidores públicos. Disseram que se o momento era de tão grave expressão, nada melhor que houvesse demonstração de austeridade financeira de quem tinha mais posses: que cortassem os deputados os seus próprios salários. ${ }^{137}$

A imprensa nacional registrou os diversos episódios destes embates que redundaram em recomendação ao Congresso para que fosse estipulado um corte de $25 \%$ nos salários de deputados e senadores a partir da legislatura seguinte porque não seria justo mudar as regras para os congressistas no exercício de seus mandatos. Parte da culpa pelos problemas atuais, diziam os deputados, era das imposições de restrição vindas do governo britânico. Os ruídos das arguições acabaram chegando à diplomacia britânica que não perdeu oportunidade de manifestação em comunicado à representação de Londres no Rio de Janeiro na qual afirmou que estas discussões careciam de propósito. ${ }^{138}$

Diplomatas britânicos entraram no centro da discussão e passaram a afirmar que os salários do setor público deveriam sim ser reduzidos, mas teria que haver ponderação porque não era possível comparar os soldos de um legislador brasileiro com o do pessoal das forças armadas ou com os prestadores de serviços públicos. A diplomacia britânica levantou dados e concluiu que se a redução de $25 \%$ fosse mesmo efetivada ainda em 1914 a economia para os cofres públicos seria da ordem de $£ 100.000$, valor nada desprezível para um país à beira da falência. ${ }^{139}$

\footnotetext{
${ }_{136}$ Proposed reduction of public salaries in Brazil, 05 agosto 1914, FO 371/1915/36043, p. 118-119.

${ }^{137}$ Ibidem, p. 120.

${ }^{138}$ Ibidem, p. 121.

139 Ibidem, p. 123-4.
} 
A situação macroeconômica exigia circunspecção com seletividade nos gastos públicos, mas não foi o que ocorreu logo após o início da guerra quando o projeto do orçamento de 1915 enviado ao Congresso estimou déficit da ordem de $£ 600.000$. À primeira vista, poderia parecer tarefa impossível eliminar em pouco tempo os dispêndios que comumente ultrapassavam as receitas, mas os tempos tinham mudado drasticamente e era de se esperar que o Ministério da Fazenda fosse além da retórica, sempre recheada com frases do tipo "o princípio adotado foi, portanto, de boa política financeira" e promovesse mudanças radicais, principalmente no lado das despesas públicas do orçamento. ${ }^{140}$ Não foi o que se viu. O primeiro projeto de orçamento nacional em tempos de guerra mundial continha gastos acima do ano anterior, período de crise, mas ainda baseado em economia internacional de regras conhecidas. A questão é que em 1915 os gastos estimados foram quase $£ 3$ milhões acima do valor estimado para o ano anterior e o próprio governo acreditava em redução nas receitas na ordem de $£ 4$ milhões porque o cenário internacional agora era outro. $\mathrm{O}$ problema já aparentava ser grave o suficiente, mas os dados preliminares do primeiro semestre de 1914 apresentaram redução ainda maior nas receitas e nada indicava que o ano seguinte seria de recuperação. $\mathrm{O}$ que se podia esperar eram receitas reduzidas em cerca de $£ 5$ milhões, número que se confirmado faria o déficit chegar a $£ 6$ milhões, patamar que não teria financiamento fácil em período de normalidade do sistema financeiro internacional e muito menos em um período de exceção como o da guerra. ${ }^{141}$

Verificados os números efetivos para despesas e receitas totais em 1915, a realidade se impôs e o déficit foi de quase $£ 20$ milhões, um dos mais elevados durante a guerra. ${ }^{142} \mathrm{Se}$ o conflito mundial não estava sendo suficiente para mudar a dependência da política econômica dos déficits orçamentários foi porque a classe hegemônica brasileira não teve sua força alterada com os eventos que se sucederam entre julho de 1914 e o final de 1918. A relação entre o público e o privado era indistinta em tal grau que o erário continuou a ser utilizado para atender os grupos economicamente mais afluentes.

$\mathrm{Na}$ Europa, o processo sobre a separação oficial entre as casas imperiais do Reino Unido e do Império Alemão acabaria por significar mais problemas para o setor externo brasileiro. A proximidade entre os primos Rei George V e o Kaiser Guilherme II manteve as

\footnotetext{
${ }^{140}$ Relatório do Ministério dos Negócios da Fazenda - 1914, p. 4.

${ }^{141}$ Brazilian Budget for 1915, agosto 1914, FO 371/1915/36044, p. 125-7.

${ }^{142}$ Ministério da Agricultura, Indústria e Comércio, Despesas: Receitas, despesas e dívidas públicas da União, Estados e Municípios, 1926. p. 13; Ministério da Agricultura, Indústria e Comércio, Receitas: Resumo de várias Estatísticas Econômico-Financeiras, 1924. p. 130.
} 
duas casas unidas, mas em 1917 a pressão da sociedade obrigou a família real britânica a adotar o nome Windsor como medida de distanciamento de suas origens germânicas. O governo britânico tentou justificar a mudança afirmando que os dois povos não compactuavam mais a mesma visão de mundo. O militarismo era o ponto de discórdia. Durante a guerra, lemas como 'British Freedom or Prussian Militarism' ou 'How is freedom measured? By the effort which it costs to retain freedom!' fizeram parte de campanhas britânicas para demonstrar os riscos à liberdade econômica que as ações estabelecidas por Berlim representavam. ${ }^{143}$ A economia brasileira passaria a ter mais problemas no relacionamento com o Império Alemão. Estava sendo trilhado o caminho para o Brasil declarar guerra à Alemanha.

Esta enfática defesa da liberdade econômica feita pelo Reino Unido contaminou a economia internacional e poderia ter produzido alterações na política econômica brasileira neste início da guerra. Em 15 de novembro de 1914 assumiu o novo presidente e o momento era adequado para alterações na economia, como sempre ocorre em novos mandatos. Apesar de Wenceslau Braz ter sido político tradicional, havia no mercado esperança que a velha política que tratava a economia como um feudo fosse finalmente alterada e que fossem libertadas forças capazes de tornar realidade os prognósticos de que o Brasil poderia ser uma grande nação. ${ }^{144}$ Para decepção de muitos estrategistas estrangeiros o status das forças políticas que atuavam no Brasil não foi desestabilizado, como pode ser constatado pelos nomes indicados pelo novo presidente para a condução dos ministérios, quase todos intimamente ligados ao senador Pinheiro Machado, grande defensor das oligarquias. O receio passou a ser que o poder do político gaúcho fizesse de Wenceslau Braz mais uma marionete dos interesses de Machado, assim como havia ocorrido com o ex-presidente Hermes da Fonseca que não conseguiu colocar características próprias em quase nenhum grande assunto nos quatro anos em que esteve à frente do executivo nacional. ${ }^{145}$ Situação análoga não ocorreu com Wenceslau Braz porque Pinheiro Machado morreu em setembro de 1915, vítima de assassinato político sem ligação aparente com a presidência da República. ${ }^{146}$

\footnotetext{
${ }^{143}$ Para propagandas mais utilizadas durante a guerra, ver: BBC (site) http://<www.ww1 propaganda.com; http://www.bbc.com/ww1>

144 "O que há de novo - Alternativa sobre o que o novo presidente deve e precisa refletir", O Estado de S. Paulo, 17 novembro 1914 , p. 3.

145 "Suggestão hypnotica - O olhar do caudilho", artigo transcrito por O Estado de S. Paulo, 13 janeiro 1914, p. 4.

${ }^{146}$ Senado Federal - Site: “Assassinato do senador gaúcho Pinheiro Machado completa 100 anos nesta terfeira".
} 
Se para o desenvolvimento econômico brasileiro era importante saber quais eram as pretensões de Sabino Barroso na Fazenda, para as potências europeias que se achavam abraçadas à guerra, os postos mais importantes na política brasileira passaram a ser os ministérios das Relações Exteriores e da Marinha. Isto não significa que questões da economia brasileira interessassem menos junto aos grandes policy makers internacionais, mas sim que a premência agora era evitar qualquer ajuda, mesmo involuntária, que o Brasil pudesse prestar ao Império Alemão. Lauro Müller, ministro das Relações Exteriores, foi mantido no cargo apesar da grande apreensão que sua ascendência germânica causava em Londres e em Paris. Preservar Lauro Müller no poder em plena guerra contra o Império Alemão somente foi possível porque, além da defesa enfática que Wenceslau Braz empreendeu do seu ministro, o próprio Müller se dedicou arduamente a conquistar a confiança de seus pares europeus por meio de inúmeras reuniões nas quais decisões relevantes eram tomadas com a anuência deles e imediatamente levadas a termo, sempre com o intuito de ratificar a isenção com a qual assuntos estratégicos internacionais eram tratados no Brasil. O fato de que o ministro da Marinha, Alexandrino de Alencar, era bisneto do general francês Pedro Labatut, combatente na Independência do Brasil, garantia aos olhos das potências da Tríplice Entente credibilidade e certo grau de segurança na qualidade do monitoramento de navios alemães em águas e portos nacionais, tarefa que se comprovou nos meses que se seguiram como o mínimo que o Ministério das Relações Exteriores e o Departamento de Comércio da Guerra do Reino Unido esperavam das autoridades brasileiras. ${ }^{147}$

A despeito das preocupações bélicas, as questões relacionadas aos passivos financeiros internacionais do governo brasileiro não se faziam esperar. Quanto mais próximo da liberação dos recursos do novo empréstimo maior era a pressão para a interferência da diplomacia britânica com o objetivo que as pendências do Brasil em ouro fossem liquidadas, mesmo que de maneira parcial, e em ação desvinculada do contrato de consolidação da dívida. Neste contexto, o caso citado da Cory Brothers \& Co foi dos mais emblemáticos tanto porque o valor reclamado era muito elevado - algo como $£ 520.000$ - quanto porque esta empresa era uma das mais importantes do País de Gales, fato que deixava Londres ainda mais contundente em suas ameaças junto ao Palácio do Catete visto que o momento era de demonstração de união no Reino Unido e de legitimação do poder concedido à Inglaterra nas questões de foro internacional.

\footnotetext{
${ }^{147}$ New Brazilian Administration, 7 dezembro 1914, FO 371/1916/83867.
} 
A dívida com a empresa galesa foi originada com a compra de larga quantidade de carvão para suprir as necessidades das ferrovias, da Companhia de Navegação Lloyd Brasileiro e da Marinha do Brasil, tendo sido a maior parte das encomendas entregues para a Estrada de Ferro Central do Brasil que totalizavam dívida de cerca de $£ 400.000 .{ }^{148} \mathrm{~A}$ chancelaria britânica buscava apenas amenizar a irritação do governo Galês e dos proprietários da empresa de carvão. Era de conhecimento geral que o único ouro ao qual o Brasil teria acesso era o do funding loan e a pendência da Cory Brothers \& Co. constava como parte credora do contrato. O que não se esperava era que no meio das negociações despontasse a guerra que retardou o acordo final com os banqueiros. Se o valor em questão fosse relacionado a alguma receita pública brasileira, o pagamento da dívida poderia ser feito por meio de vinculação e transferência automática de valores, como ocorrido no caso Stothert \& Pitt, empresa de construção portuária que conseguiu receber parte do que o Porto do Rio de Janeiro devia com o bloqueio do faturamento da renda portuária até o total devido de $£$ 25.000. ${ }^{149}$ Esta ação de penhora de receitas públicas com base em pendência comercial de empresa privada de capital britânico é sintomática da força do governo britânico sobre o setor público do Brasil.

A deterioração no cenário econômico se acentuou consideravelmente no segundo semestre e quanto mais se postergava a liberação do funding loan, mais rapidamente se desvalorizava o mil-réis, razão de muita preocupação para o comércio importador e para os credores estrangeiros que possuíam títulos brasileiros. Com o default do governo federal, os rendimentos destes títulos somente seriam pagos após a entrada dos recursos do empréstimo em moeda forte, mas à taxa cambial do dia quando este pagamento se concretizasse. Muitos investidores estrangeiros solicitavam ajuda à diplomacia britânica porque eles se desesperavam ao ver o mil-réis comprando cada vez menos libras esterlinas, como se sucedeu com a família de classe média inglesa Gibbons que há mais de cinquenta anos era detentora de papéis brasileiros e que ficou preocupada ao ver a taxa cambial no Brasil despencar de 16 d. para 12 d. Situações análogas não chegavam ao conhecimento do Ministério da Fazenda no Rio de Janeiro porque o corpo diplomático britânico se encarregava de explicar que a obrigação do Tesouro do Brasil era pagar os dividendos em mil-réis e que o risco da variação cambial corria inteiramente por conta do credor no exterior à época da conversão, regra

\footnotetext{
${ }^{148}$ Cory Brothers claim against Brazil, 7 outubro 1914, FO 371/1916/56839, p. 187-193.

${ }^{149}$ Claim vs. Port Authorities at Rio de Janeiro, 09 outubro 1914, FO 371/1916/58001, p. 274.
} 
precípua do mercado financeiro internacional, informava didaticamente a diplomacia britânica. $^{150}$

A espera de novos recursos em ouro foi fator de instabilidade porque indicava o grau de apreensão do mercado entre o início da guerra e a liberação dos recursos do funding. Como se observa na Tabela 3.3, o valor do mil-réis passou por desvalorizações elevadas até outubro de 1914 quando o contrato foi finalmente assinado em Londres permitindo a recuperação da moeda nacional ao final do ano.

Tabela 3.3 - Taxa cambial - média diária para a sexta-feira de cada semana até o final de junho de 1914 e diária a partir de então, até o final de 1914 (pence / Rs)

\begin{tabular}{l|r|r|r|rr}
\hline \multicolumn{2}{c}{ Maior } & Menor & Média & $\begin{array}{l}\text { Média } \\
\text { Mensal }\end{array}$ & $\begin{array}{r}\text { variação \% } \\
\text { s/30 junho }\end{array}$ \\
\hline até 30/06 & 16,19 & 15,75 & 15,97 & & \\
Julho & 16,09 & 14,69 & 15,39 & $-3,63 \%$ & $-3,63 \%$ \\
Agosto & 14,13 & 14,00 & 14,07 & $-8,61 \%$ & $-11,93 \%$ \\
Setembro & 13,00 & 11,63 & 12,32 & $-12,44 \%$ & $-22,89 \%$ \\
Outubro & 15,00 & 10,44 & 12,72 & $3,29 \%$ & $-20,35 \%$ \\
Novembro & 14,13 & 13,25 & 13,69 & $7,63 \%$ & $-14,28 \%$ \\
Dezembro & 15,13 & 13,63 & 14,38 & $5,04 \%$ & $-9,96 \%$ \\
\hline
\end{tabular}

Fonte: Bank of Brazil, 1/11865/10907, 3 maio 1915, pasta Treasury.

Quando o comportamento do câmbio é analisado tendo como referência o valor registrado em 30 de junho é possível notar que o bimestre setembro/outubro foi o pior momento em termos de expectativas macroeconômicas. Nesse ponto, o pessimismo tomou conta do mercado e a busca por proteção somada à especulação fizeram a libra passar a valer cerca de $20 \%$ acima da cotação referencial, cotação esta que não foi retomada nem mesmo após o fluxo de ouro ter sido liberado ao Brasil pelos banqueiros internacionais. Sinais de ambiente econômico conturbado também podem ser observados na diferença entre o maior e o menor valor do câmbio para os meses do segundo semestre, especialmente em outubro quando a cotação oscilou entre 15 d. e 10,44 d.

As incertezas eram muitas e envolveram diversos negócios internos, servindo de matéria farta para a imprensa especular sobre qual seria o limite para a retração no movimento comercial em São Paulo que já vinha de números bastante enfraquecidos devido à crise de

${ }^{150}$ Dividends on Brazilian Bonds, 25 setembro 1914, FO 371/1916/52969, carta de Marguerite Gibbons datada de 23 setembro 1914. 
1913. ${ }^{151}$ Enquanto o dinheiro forte não era liberado, a única saída parecia ser a emissão de moeda, solução defendida por analistas econômicos e por políticos como Cincinato Braga. Em discurso no Congresso, Cincinato atacou em análise retrospectiva os que ainda ousavam se pronunciar metalistas e que não queriam admitir que a guerra era um regime de exceção que havia surpreendido até mesmo as mais preparadas nações europeias. Não se poderia esperar do Brasil algum tipo de ortodoxia em um momento no qual o pedido de empréstimo brasileiro parecia ter sido colocado no último grau de prioridade do mercado financeiro internacional. $^{152}$

Passado o momento mais tenso do início da guerra, as negociações dos banqueiros internacionais com o governo brasileiro sobre o funding loan puderam ser retomadas porque em meados do segundo semestre de 1914 o mercado financeiro internacional foi tomado pela esperança que a guerra seria resolvida em poucos meses e os negócios retomados. Com relação ao Brasil, o que estava em discussão eram milhões de libras esterlinas que seriam alocadas na conta do país, recursos que naturalmente acabariam no caixa de empresários britânicos porque muito da atividade econômica brasileira passava pelo Reino Unido. Em 19 de outubro de 1914 o contrato foi assinado em Londres pelo delegado do Tesouro brasileiro no Reino Unido, Joaquim Ignacio Tosta, e por N. M. Rothschild \& Sons que representou os banqueiros internacionais. O desfecho representou alívio momentâneo para as finanças públicas e para o setor importador. ${ }^{153}$

Desta consolidação da dívida externa brasileira foram parte integrante parcelas de amortização e juros não pagos sobre empréstimos de 1883, 1888, 1889, 1895, 1908, 1910, 1911 e 1913, além de juros sobre títulos e garantias de estradas de ferro, do Lloyd Brasileiro, do Porto de Recife. O pagamento de juros em dinheiro ficaria suspenso até 31 de julho de 1917 e a liquidação das amortizações até 31 de julho de 1927, período durante o qual seriam emitidos para liquidação títulos denominados 'funding' com juros de 5\% ao ano, que somados não poderiam ultrapassar o limite de $£ 15$ milhões e teriam como garantia a renda aduaneira das alfândegas, especialmente a do Rio de Janeiro. O resgate foi estipulado para ocorrer em período de até 63 anos, contados a partir de 1 de agosto de 1927. Foi facultada ao governo brasileiro a aplicação de $£ 2,5$ milhões em estradas de ferro e portos que deveriam ter tarifas cobradas em ouro o que serviria como garantia para a operação. Ficou acordado que

\footnotetext{
151 'Estudos Econômicos’, O Estado de S. Paulo, 16 agosto 1914, p. 2.

152 “A Questão Financeira - Discurso do Deputado Federal Cincinato Braga”, O Estado de S. Paulo, 22 agosto 1915 , p. 4

153 “Contracto do Novo Funding” - 'Relatório do Ministério dos Negócios da Fazenda - 1914', p. 55.
} 
Rothschild \& Sons receberia $1 \%$ como remuneração sobre o valor nominal de cada título por eles emitido e $0,25 \%$ sobre o valor nominal de cada título emitido por outras casas internacionais. ${ }^{154}$

Era chegado o momento de tentar algum caminho para tirar o país da crise. Apesar dos efeitos ainda não totalmente decodificados da guerra sobre os negócios internos e externos do país, os últimos meses de 1914 concentraram dois fatores positivos: a normalização do passivo externo do país por meio do empréstimo de consolidação e o início do governo de Wenceslau Braz, que teve como plataforma de campanha reposicionar o Brasil neste cenário de guerra global.

Houve tempo para discussões ideológicas sobre qual dos dois lados da guerra Tríplice Entente ou a Tríplice Aliança - seria o melhor para a realidade dos negócios do país, mas questões econômicas básicas tiveram tal premência que a prática da política internacional dependeu em todos os sentidos das possibilidades para a obtenção de divisas. Não eram muitas as chances de sanar a falta de ouro. A redução na renda aduaneira sufocava a governabilidade do país. Se a crise de 1913 demonstrou os seus efeitos sobre as importações no primeiro semestre de 1914, as restrições logísticas ao comércio internacional marcaram a política econômica nacional durante a guerra e muita diplomacia teve que ser utilizada para a abertura de portas na economia internacional. Para ideia da gravidade da situação, nos cinco primeiros meses de guerra as importações foram reduzidas para apenas $£ 8,5$ milhões, contra $£ 26$ milhões no mesmo período do ano anterior. O mercado estimou em $£ 10$ milhões os efeitos da guerra sobre o comércio importador, o que fez deste período um dos piores da história econômica do Brasil, até mesmo em comparação ao verificado na crise de $1901 .^{155}$

Conclusão

O funding loan foi necessário para o financiamento da economia brasileira devido à crise de 1913. A Primeira Guerra Mundial foi responsável pelo agravamento dos problemas na economia brasileira e pelo adiamento da assinatura do contrato de consolidação da dívida externa brasileira. Se guerra não tivesse se iniciado em julho de 1914, o contrato teria sido assinado em melhores condições e antes do que acabou ocorrendo.

154 “Contracto do Novo Funding” - 'Relatório do Ministério dos Negócios da Fazenda - 1914', p. 56-8.

${ }^{155}$ Brazil - Foreign Trade during 1910-1914, 09 março 1915, T1/11865/6355, carta nr. 06, British Consulate General, Rio de Janeiro. 
A Primeira Guerra alterou a lógica da economia internacional, com graves consequências para a economia brasileira que era dependente de recursos em ouro. Nesta nova lógica, o mercado para o café brasileiro passou a depender de negociações entre os governos do Brasil e do Reino Unido. A estrutura de cartelização do mercado do café que funcionava com base nas regras do Convênio de Taubaté perdeu eficácia. Tentativas de negociar o produto nos Estados Unidos teriam eu seguir novos ditames.

A guerra alterou profundamente as condições para o comércio exterior brasileiro. Rotas de transporte foram suprimidas ou dificultadas pelos ataques da marinha alemã. Fornecedores tradicionais com sede nos países da Aliança não puderam ser substituídos. Isto significou ausência de muitos produtos para o comércio e para a indústria no Brasil. As restrições nas importações geraram oportunidades para a industrialização nacional, mas foram eventos que não tiveram força para alterar o predomínio do setor agrícola na economia nacional. O governo não tinha um plano de industrialização nacional que pudesse ser executado durante a guerra. Este assunto não foi discutido com os credores em Londres. $\mathrm{O}$ assunto sobre a industrialização brasileira durante a Primeira Guerra Mundial raramente aparece nos documentos sobre o Brasil arquivados no National Archives.

A grande preocupação do governo brasileiro no período no qual o país foi neutro na guerra era sobre como obter recursos para financiar o orçamento. As alterações no comércio exterior exigiram adaptações na política econômica brasileira. As caraterísticas dos orçamentos públicos do Brasil durante a guerra serão tratadas no próximo capítulo. 


\section{Capítulo 4 - Orçamento público do Brasil em tempos de guerra}

Os orçamentos públicos do Brasil eram realizados em papel e em ouro. Papel eram recursos em mil-réis não conversíveis. Ouro era o nome que se dava às divisas, essencialmente a libra inglesa. Para a obtenção de papel havia a possibilidade de impressão de moeda em curso forçado, mas o acesso ao ouro somente era possível via exportações, investimentos estrangeiros ou empréstimos.

Os déficits eram uma constante, motivo de muita discussão entre o governo e o Congresso. Estes déficits não ficavam restritos ao orçamento. Muitas autorizações para gastos extraordinários faziam as despesas ultrapassarem ainda mais as receitas. Antes da Primeira Guerra Mundial, foi possível obter financiamento internacional que permitia atender parte da demanda por ouro. Com a guerra, o governo brasileiro foi obrigado a buscar novas fontes de receitas, como os impostos sobre o consumo e sobre a renda.

A forma como a guerra influenciou o a política econômica brasileira guarda relação profunda com a administração dos orçamentos públicos. Como se verá no capítulo que se inicia, os impactos da guerra nas contas públicas do Brasil não foram uniformes. Conforme os conflitos se desenvolviam na Europa, mudanças eram exigidas no Brasil, mostrando o grau de dependência que economia interna tinha do setor externo. Este capítulo mostra como a guerra aumentou esta dependência e quais foram as respostas do governo brasileiro.

Seção 4.1 - A dependência dos orçamentos do imposto de importação

Os eventos internacionais que culminaram na Primeira Guerra Mundial atingiram a economia brasileira no ponto de maior fragilidade: a dependência do imposto de importação para o financiamento do setor público. O conflito provocou principalmente diminuição nas exportações de café e borracha, mas o golpe mais forte na política econômica foi mesmo sentido nas importações pela redução generalizada na oferta de bens de consumo e de máquinas e equipamentos, no encarecimento dos fretes internacionais e nas restrições ao livre comércio impostas pela França e pelo Reino Unido aos países neutros até o segundo semestre de 1917 quando o Brasil passa a posição de beligerante. 
As importações eram o principal fato gerador das rendas aduaneiras, e como estas representavam a maior parte das receitas da União para o orçamento em ouro, o governo Wenceslau Braz foi obrigado a realizar diversos expedientes que preenchessem o vácuo deixado pela redução das receitas com queda nas importações. Um dos artifícios empregados foi a ampliação do imposto sobre o consumo que era até o início da guerra simples coadjuvante orçamentário. Em escala menor, outro tributo que também teve sua dimensão aumentada foram as rendas industriais, demonstrando algum grau de crescimento da importância do setor secundário durante a guerra mundial. $\mathrm{O}$ imposto sobre a renda teve um papel discreto na tributação porque os obstáculos para a execução de uma reforma que colocasse o país mais dependente de tributos fiscais foram enfrentados apenas até o ponto no qual a situação da arrecadação do imposto de importação começou a dar sinais de recuperação ao final de 1917.

As despesas e os déficits públicos durante o período foram alvo de muito discurso do poder executivo que sempre afirmava que a austeridade seria buscada a qualquer preço porque era necessário enfrentar a conjuntura desfavorável trazida pela guerra, mas a prática foi muito diferente da retórica. Ciente que estava das dificuldades em continuar a movimentar a máquina pública da mesma forma como os governos republicanos vinham fazendo, o governo Wenceslau Braz permitiu a elevação das despesas entre 1914 e 1918, deixando sempre um déficit em moeda não conversível, impossível de ser liquidado mesmo que a renda aduaneira voltasse ao nível de antes da guerra.

As tentativas em colocar ordem no caos orçamentário advindo com a guerra se fizeram patentes, como será visto neste capítulo, no desempenho do Ministério da Fazenda que teve Pandiá Calógeras como figura onipresente e a discussão sobre métodos ortodoxos ou heterodoxos de condução da economia como tema central. Por métodos ortodoxos entendiamse a impressão do mil-réis somente com lastro em libras esterlinas e a disciplina fiscal como alvo. A prática não ortodoxa era traduzida no curso forçado, na impressão de moeda sem a contrapartida em moeda conversível e na adequação do orçamento às exceções que o conflito mundial impunha e que significavam déficits fiscais recorrentes.

Os orçamentos entre 1913 e 1919 foram estruturados no campo das receitas e no das despesas em mil-réis papel e mil-réis ouro, moeda de livre câmbio com a libra esterlina. A dependência que o governo federal tinha do imposto de importação como principal fonte financiadora tanto para os dispêndios em papel quanto para os gastos em ouro mostra como a 
política econômica foi alterada com a guerra. Ao longo do governo Wenceslau Braz, o imposto de importação perdeu a distinção absoluta que o acompanhava desde o Império e novos tributos assumiram parte da arrecadação que antes vinha com as rendas aduaneiras, os maiores destaques ficando para o imposto sobre o consumo e as rendas industriais, tributos de maior qualidade tributária. O problema é que estes tributos não puderam atender a demanda por ouro orçamentário, o que aumentou a pressão para a contratação de empréstimos e financiamentos no exterior.

Os planejamentos orçamentários da União entre os anos de 1913 e 1919 já nasciam com déficits em papel, assim eram aprovados pelo Congresso e se transformavam em leis. Estes déficits foram de 30\% em 1913, de $20 \%$ na média entre 1914 e 1918 e de 0,3\% em 1919, sempre em relação aos valores em papel. Em ouro, os orçamentos foram aprovados com superávit de $30 \%$ em média para o período pesquisado. Como será demonstrado, os gastos efetivos em ouro e em papel resultaram em déficits para todo o período pesquisado. ${ }^{156}$

Os estados eram em sua maioria entes federativos fracos e submissos ao poder central, a não ser os estados como São Paulo que podiam se financiar com base no imposto de exportação, situação que o deixava com grande poder de barganha junto à União porque era de suas exportações que o país adquiria a maior parte das divisas necessárias ao funcionamento da economia. ${ }^{157}$ A guerra teve efeitos mais graves para as receitas da União do que para os estados e municípios, como se pode observar na Tabela 4.1. Enquanto o governo federal perdeu quase 35\% de arrecadação entre 1913 e 1914, os estados tiveram que enfrentar redução de pouco mais de $10 \%$ e os municípios não sentiram os efeitos negativos da guerra em termos receitas. Na verdade, tanto estados quanto municípios arrecadaram mais durante o conflito do que em 1913 e terminaram o período em situação financeira bem melhor do que a União que não voltou ao nível pré-guerra nem mesmo em 1919. Este é o principal motivo para que considerações sobre mudanças fiscais originadas com a guerra se concentrem na esfera federal.

\footnotetext{
${ }^{156}$ Leis orçamentárias entre 1913 e 1919; Resumo de várias estatísticas econômico-financeiras, 1924, p.131.

${ }^{157}$ Retrospecto Comercial 1917, p.9.
} 
Tabela 4.1 - Receita da União, dos Estados e dos Municípios, 1913-1919 (contos de réis)

\begin{tabular}{|c|c|c|c|c|c|c|}
\hline & \multicolumn{6}{|c|}{ Receita Arrecadada } \\
\hline & União & $1913=100$ & Estados & $1913=100$ & Municípios & $1913=100$ \\
\hline 1913 & 654 & 100 & 229 & 100 & 134 & 100 \\
\hline 1914 & 423 & 65 & 202 & 88 & 134 & 100 \\
\hline 1915 & 486 & 74 & 243 & 106 & 140 & 105 \\
\hline 1916 & 478 & 73 & 258 & 113 & 143 & 108 \\
\hline 1917 & 537 & 82 & 278 & 121 & 147 & 110 \\
\hline 1918 & 619 & 95 & 282 & 123 & 157 & 117 \\
\hline 1919 & 626 & 96 & 346 & 151 & 171 & 128 \\
\hline
\end{tabular}

Fonte: Ministério da Agricultura, Indústria e Comércio. Resumo de várias Estatísticas Econômico-Financeiras. Diretoria Geral de Estatística. Rio de Janeiro, 1924, p. 130.

Entre 1913 e 1919 a União sofreu com a queda na arrecadação e ainda teve que enfrentar uma situação nova e delicada em termos políticos: sua participação no total arrecadado foi reduzida em aproximadamente 10\%, como indicado na Tabela 4.2, e os estados se apropriaram da maior parte desta fatia perdida. Este fato contribuiu para aumentar as consequências políticas em um sistema federalista no qual o poder que o estado de São Paulo amealhou como o maior exportador de café já era evidente.

Tabela 4.2 - Receita da União, dos Estados e dos Municípios, 1913-1919 (contos de réis)

\begin{tabular}{|c|c|c|c|c|c|c|}
\hline & \multicolumn{2}{|c|}{$\begin{array}{l}\text { Receita } \\
\text { Arrecadada }\end{array}$} & \multirow[b]{2}{*}{ União } & \multirow[b]{2}{*}{ Estados } & \multirow[b]{2}{*}{ Municípios } & \multirow{2}{*}{$\begin{array}{c}\text { Números- } \\
\text { índices do } \\
\text { Total }\end{array}$} \\
\hline & Total & $1913=100$ & & & & \\
\hline 1913 & 1.017 & 100 & 64 & 22 & 13 & 100 \\
\hline 1914 & 759 & 75 & 56 & 27 & 18 & 75 \\
\hline 1915 & 869 & 85 & 56 & 28 & 16 & 85 \\
\hline 1916 & 879 & 86 & 54 & 29 & 16 & 86 \\
\hline 1917 & 963 & 95 & 56 & 29 & 15 & 95 \\
\hline 1918 & 1.057 & 104 & 59 & 27 & 15 & 104 \\
\hline 1919 & 1.143 & 112 & 55 & 30 & 15 & 112 \\
\hline
\end{tabular}

Fonte: Resumo de várias Estatísticas Econômico-Financeiras. Ministério da Agricultura, Indústria e Comércio. Diretoria Geral de Estatística. Rio de Janeiro, 1924, p. 130.

O estudo sobre as receitas e as despesas da União durante o período envolveu a coleta dos dados dos orçamentos, da arrecadação e dos gastos efetivos para cada um dos exercícios de 1913 a 1919. As fontes foram as leis orçamentárias dos sete anos analisados do período e os relatórios estatísticos publicados pelo Ministério da Agricultura, Indústria e Comércio em 1924 e 1926 que contêm dados sobre arrecadação efetiva e despesas realizadas no período. 
Todos os lançamentos para receitas e despesas ordinárias e especiais entre 1913 e 1919 foram sistematizados.

Os orçamentos são as próprias leis promulgadas ao final de dezembro do ano anterior, caso das receitas, e no início do ano fiscal seguinte, caso das despesas, e que deveriam valer para todo o exercício em questão. Deveriam, porque decretos foram publicados alterando especificações nas leis, modificando os orçamentos aprovados pelo Congresso que já havia alterado o texto do executivo. ${ }^{158}$ Outro motivo para as modificações nos orçamentos foram as fases da elaboração orçamentária que eram divididas em proposta do governo, parecer da comissão, votação da Câmara e votação do Senado. Depois de tudo aprovado e sancionado pelo presidente da República, o Congresso ainda tinha o poder de alterar os valores que deveriam ser os finais. ${ }^{159}$

Os debates sobre as mudanças tributárias que o governo tentava aprovar no Congresso deixam claro que o período da Primeira Guerra Mundial foi muito ativo no que se refere às disputas ideológicas sobre o papel do Estado no desenvolvimento econômico e que mais tarde ganhariam vulto, especialmente a discussão sobre indústria natural e indústria artificial, como registrado por Nícia Vilela Luz no livro A luta pela industrialização no Brasil.

Entre 1915, quando o imposto de importação declinou 30\% em relação ao ano anterior em termos de importância para o total do orçamento, o governo passou a contar com a emissão de títulos da dívida externa de acordo com contrato celebrado no funding loan de 1914 que liberou recursos equivalentes a 44,2\% das necessidades em ouro. A mesma solução foi adotada para 1916, com a emissão de títulos representando 45,5\% do orçamento. Em 1917, além dos recursos da emissão de títulos da dívida externa foram alocados para o orçamento o equivalente a $15 \%$ das necessidades em ouro por meio do resgate de fundos em Londres. Foi patente a preocupação do governo em conseguir recursos que pudessem compensar a drástica redução na arrecadação que antes era garantida pelo imposto de importação. Isto foi feito de todas as formas possíveis, inclusive com expedientes financeiros necessários para o executivo poder utilizar recursos provenientes, por exemplo, do arrendamento de navios do Lloyd, recursos estes que em 1918 representaram providenciais 33,8\% das necessidades em ouro para o exercício, permitindo um saque menor do fundo em Londres. Com a melhora no desempenho das importações em 1919, a dependência de fontes

\footnotetext{
${ }^{158}$ Lei Orçamentária 1917, p. 145.

${ }^{159}$ Lei Orçamentária, 1917, p. 22.
} 
extraordinárias diminuiu e o saque em Londres no valor de aproximadamente 17.800 contos de réis foi suficiente para fechar as contas. ${ }^{160}$

Seção 4.2 - As modificações que a guerra trouxe para a tributação

A Primeira Guerra Mundial não teve o poder de alterar as bases da economia brasileira com a mesma extensão do que se passou na Europa onde o choque foi significativo a ponto de ser considerado um divisor de águas entre o século XIX e o século XX. ${ }^{161}$ Estas mudanças na conjuntura europeia acabariam por se espalhar pelo mundo e chegariam ao Brasil em etapas. O verdadeiro impacto da guerra em termos de política fiscal no Brasil foi o de intensificar os problemas que já existiam e forçar a sociedade a buscar soluções para questões que podem ser resumidas em má gestão pública, ausência de equilíbrio fiscal, dependência excessiva do tributo de importação, carga tributária por demais carregada no comércio e uma relação público-privada de baixa qualidade. Pode-se afirmar que o estopim para as mudanças necessárias na economia brasileira aconteceu durante a guerra. As fontes de arrecadação e os tipos de dispêndios que um país ainda essencialmente agrícola como o Brasil tinha eram simples. Readequações financeiras e contábeis foram necessárias para se tentar obter um orçamento e que permitisse a governabilidade em um momento tão instável como a da Primeira Guerra.

A consequência mais direta que a guerra trouxe para as finanças públicas do Brasil foi a premência de se encontrar substitutos das rendas aduaneiras que chegaram a ser reduzidas à metade durante a guerra. As relações entre valores arrecadados e orçados para o imposto de importação, bem como o impacto das diferenças sobre o orçamento podem ser observadas nas tabelas 4.3 e 4.4 .

\footnotetext{
${ }^{160}$ Retrospecto Comercial, 1914, p. 118.

161 Temin, Peter et al, The world economy between the World Wars, capítulo 2.
} 
Tabela 4.3 - Brasil - Impostos de importação, 1913-1919 (contos de réis, ouro)

Impostos de importação, de entrada e saída de navios e adicionais.

OURO

\begin{tabular}{r|r|r|r|r}
\multicolumn{2}{c}{ Orçamento } & Arrecadação & \multicolumn{2}{c}{$\begin{array}{c}\text { D sobre } \\
\text { Diferençamento }\end{array}$} \\
\hline 1913 & 102.601 & 99.469 & -3.132 & $-3,1$ \\
1914 & 99.780 & 52.930 & -46.850 & -47 \\
1915 & 60.060 & 35.016 & -25.044 & $-41,7$ \\
1916 & 54.000 & 46.149 & -7.850 & $-14,5$ \\
1917 & 70.400 & 50.509 & 52.930 & $-28,3$ \\
1918 & 63.324 & 55.170 & 35.015 & $-12,9$ \\
1919 & 82.072 & 70.788 & -11.285 & $-13,8$ \\
Média & 76.034 & 58.576 & -17.458 & -23 \\
\hline
\end{tabular}

Fonte: Ministério da Agricultura, Indústria e Comércio, Receitas, despesas e dívidas públicas da União, 1926, anexo, p.6.

Em ouro, a redução foi muito acentuada logo no primeiro ano da guerra e mesmo com a redução que o governo empreendeu nos valores orçados a partir de 1915, a arrecadação permaneceu reduzida até o final do conflito, voltando a se recuperar em parte somente em 1919. Este choque adverso na arrecadação em ouro trouxe todo um arsenal de modificações na política fiscal de Wenceslau Braz, como a urgência no funding loan. Não foi nada simples encontrar fontes de recursos em ouro substitutas ao imposto de importação. O funding loan, o aumento das quotas de importação em ouro, o arrendamento de navios, além dos recursos destinados às melhorias dos portos foram as soluções que o governo logrou ao longo da Primeira Guerra Mundial. ${ }^{162}$

A situação em papel não foi muito melhor, mas ao menos as fontes de recursos que compensassem o imposto de importação poderiam ser encontradas internamente em uma economia com renda nacional que já dava sinais de assimilar o aumento de tributos considerados mais modernos, tributos característicos de uma sociedade mais urbana.

$\overline{{ }^{162} \text { Leis Orçamentárias - Receitas - }} 1913$ a 1919. 
Tabela 4.4 - Impostos de importação orçados e arrecadados, Brasil, 1913-1919 (contos de réis)

Impostos de importação, de entrada e saída de navios e adicionais.

Papel

\begin{tabular}{c|c|c|c|c}
\multicolumn{1}{c}{} & \multicolumn{1}{c}{ Orçamento } & Arrecadação & \multicolumn{1}{c}{ Diferença } & $\%$ \\
\hline 1913 & 178.595 & 176.025 & -2.567 & $-1,4$ \\
1914 & 172.365 & 97.618 & -74.747 & $-43,4$ \\
1915 & 106.200 & 76.416 & -29.784 & $-28,1$ \\
1916 & 81.000 & 79.783 & -1.217 & $-1,5$ \\
1917 & 57.600 & 48.102 & -9.498 & $-16,5$ \\
1918 & 51.498 & 52.538 & 1.040 & 2,0 \\
1919 & 66.565 & 65.136 & -1.429 & $-2,2$ \\
Média & 101.975 & 85.088 & -16.886 & $-0,13$ \\
\hline
\end{tabular}

Fonte: Ministério da Agricultura, Indústria e Comércio, Receitas, despesas e dívidas públicas da União, Estados e Municípios, 1926, anexo, p.6.

A redução na arrecadação do imposto de importação em ouro já era um grave problema ao qual foi adicionada a queda na arrecadação do mesmo tributo em papel. Nota-se na Tabela 4.4 que a redução na arrecadação foi bastante acentuada em 1914, o que provocou redução na estimativa para as receitas com o imposto de importação para o ano seguinte, mas mesmo assim a diferença para a arrecadação em 1915 foi substancial, com importantes desdobramentos para a política fiscal, sendo o mais importante a mudança na fonte de recursos que passou a incluir principalmente o imposto sobre o consumo.

É possível verificar que o imposto de importação era essencial para as finanças públicas do período. Comparando-o com os demais tributos, fica evidente que alterações na arrecadação deste imposto teria impacto na política econômica. A Tabela 4.5 contém o orçamento para as receitas de 1914, ainda com os dados poupados das mudanças que seriam feitas no orçamento nos exercícios subsequentes. Extraindo-se do orçamento apenas os números relativos à Renda dos Tributos, é possível notar que o imposto de importação foi responsável neste ano por praticamente toda a arrecadação em ouro aguardada para o exercício e que em papel somava quase a metade das fontes esperadas de receitas. 
Tabela 4.5 - Renda dos tributos orçados, Brasil, 1914 (contos de réis, ouro e papel)

\begin{tabular}{l|c|c|c|c}
\hline Renda dos Tributos & Ouro & \multicolumn{2}{c}{ Papel } & $\%$ \\
\hline Imposto de Importação & 96.840 & 92,0 & 162.215 & 46,7 \\
Imposto em ouro (2\%) sobre cevada e & 1.000 & 0,9 & & \\
outros cereais & 1.400 & 1,3 & 3.000 & 0,9 \\
Expediente sobre produtos livres de & & & 1.600 & 0,5 \\
imposto de consumo & & & 4.500 & 1,3 \\
Expediente de capatazias & & & 600 & 0,2 \\
Armazenagem & 390 & 0,4 & & \\
Taxa de estatística & 150 & 0,2 & & \\
Impostos de faróis (de porto) & & & 450 & 0,1 \\
Imposto de faróis (docas) & 99.780 & 94,8 & 172.365 & 49,6 \\
Expediente sobre produtos isentos (10\%) & & & \\
Total & & & & \\
\hline
\end{tabular}

Fonte: Lei Orçamentária para o exercício de 1914, Receita Geral da República do Brasil para o exercício de 1914. Lei 2.841, de 31 de dezembro de 1913.

Em 1918, após a guerra ter provocado redução na arrecadação tributária e este fato ter sido espelhado nos orçamentos, a renda dos tributos passou por modificação significativa em termos de importância para as finanças públicas, com a participação do imposto de importação em ouro tendo sido reduzida para a metade do que era em 1914 e em papel não conversível para apenas $11,7 \%$, representando redução de $35 \%$ frente ao ano do início do conflito mundial, como demonstrado na Tabela 4.6.

Tabela 4.6 - Renda dos tributos orçados, Brasil, 1918 (contos, ouro e papel)

\begin{tabular}{|c|c|c|c|c|}
\hline Renda dos tributos & Ouro & $\%$ & papel & $\%$ \\
\hline Imposto de importação & 62.208 & 54,1 & 49.923 & 11,7 \\
\hline Imposto em ouro ( $2 \%$ ) sobre cevada e outros cereais & 720 & 0,6 & & \\
\hline $\begin{array}{l}\text { Expediente sobre produtos livres de imposto de } \\
\text { consumo }\end{array}$ & 144 & 0,1 & 270 & 0,1 \\
\hline Expediente de capatazias & & & 405 & 0,1 \\
\hline Armazenagem & & & 540 & 0,1 \\
\hline Taxa de estatística & & & 315 & 0,1 \\
\hline Impostos do faróis (de porto) & 225 & 0,2 & & \\
\hline Imposto de docas & 27 & 0,0 & & \\
\hline Expediente sobre produtos isentos $(10 \%)$ & & & 45 & 0,0 \\
\hline Total & 63.324 & 55,1 & 51.498 & 12,0 \\
\hline
\end{tabular}

Fonte: Lei orçamentária para o exercício de 1918, Receita Geral da República do Brasil para o exercício de 1918. Lei 3446 - 31 de dezembro de 1917.

As mudanças trazidas pela guerra para a politica fiscal podem ser avaliadas também por meio da comparação do grau de dependência que o setor público tinha do imposto de 
consumo que terminou o período como responsável por aproximadamente $30 \%$ do orçamento, o dobro do que era em 1914, conforme indicado na Tabela 4.7.

Tabela 4.7 - Renda dos tributos e imposto de consumo em relação ao orçamento, Brasil, 1913-1919 (contos de réis, ouro e papel)

\begin{tabular}{|c|c|c|c|}
\hline & \multicolumn{2}{|c|}{ Renda dos Tributos } & $\begin{array}{l}\text { Imposto de Consumo } \\
\text { Papel }\end{array}$ \\
\hline 1913 & 94,7 & 50,6 & 17,0 \\
\hline 1914 & 94,8 & 49,6 & 17,2 \\
\hline 1915 & 63,0 & 36,7 & 21,2 \\
\hline 1916 & 56,1 & 24,2 & 21,2 \\
\hline 1917 & 60,5 & 17,6 & 31,3 \\
\hline 1918 & 55,1 & 12,0 & 28,4 \\
\hline 1919 & 81,5 & 14,0 & 27,6 \\
\hline Média & 72,2 & 29,2 & 23,4 \\
\hline
\end{tabular}

Fonte: Leis orçamentárias para os exercícios de 1913 a 1919.

Dada a necessidade que o governo tinha em localizar outras fontes de receitas em ouro, o orçamento de 1914 foi acrescido da conta de Renda com Aplicação Especial, uma espécie de apêndice ao orçamento principal, cujos valores não eram somados ao total, mas que representaram para o orçamento em questão $24 \%$ do total orçado para o ano, percentual significativo e que dependia da cota-ouro e do fundo destinado às obras de melhorias dos portos. Apesar de se tratar de renda especial, recursos sobre os quais o governo tinha garantias mais sólidas de arrecadação do que dos tributos regulares, a redução da arrecadação também afetou as estimativas de receitas, especialmente nos primeiros anos da guerra. Pode-se notar que a prática de estimar receitas fora do orçamento principal foi perdendo importância ao longo do período, como mostra a Tabela 4.8. 
Tabela 4.8 - Renda com aplicação especial, valores orçados e arrecadados, Brasil, 1913-1919 (contos de réis, ouro e papel)

Renda com aplicação especial

Ouro

Papel

\begin{tabular}{c|c|c|c|c|c|c|c|c}
\multicolumn{3}{c}{ Orçamento Arrecadação Diferença } & \multicolumn{2}{c}{ \% } & \multicolumn{2}{c}{ Orçamento Arrecadação Diferença } & $\%$ \\
1913 & 23.730 & 29.425 & 5.695 & 24,0 & 17.850 & 24.731 & 6.881 & 38,5 \\
1914 & 24.920 & 15.146 & -9.774 & $-39,2$ & 35.700 & 20.728 & -14.972 & $-41,9$ \\
1915 & 20.137 & 11.239 & -8.898 & $-44,2$ & 21.502 & 11.205 & -10.297 & $-47,9$ \\
1916 & 14.495 & 12.768 & -1.727 & $-11,9$ & 14.215 & 10.847 & -3.368 & $-23,7$ \\
1917 & 12.025 & 13.070 & 1.045 & 8,7 & 12.838 & 15.374 & 2.536 & 19,8 \\
1918 & 10.970 & 10.384 & -586 & $-5,3$ & 19.978 & 18.111 & -1.867 & $-9,3$ \\
1919 & 12.888 & 13.967 & 1.079 & 8,4 & 39.566 & 18.504 & -21.062 & $-53,2$
\end{tabular}

Fonte: Ministério da Agricultura, Indústria e Comércio, Receitas, despesas e dividas públicas da União, Estados e Municípios, 1926, anexo, p.6.

É muito provável que se a dependência do setor público fosse por moeda não conversível, o imposto sobre o consumo poderia ter sido utilizado em escala mais ampla, mas a falta que os recursos em moeda forte fazia era crucial para as finanças públicas. Havia outro elemento a ser somado à situação: o governo teve que administrar uma situação de substituição de um tributo como imposto de importação por um tributo criado com o objetivo de arrecadar, como o imposto sobre o consumo.

Além das mudanças já observadas para o imposto de importação e para o imposto de consumo, valem observações sobre outros tributos, como o imposto do selo, que praticamente dobrou de arrecadação em moeda não conversível durante a guerra e em ouro chegou a arrecadar três vezes o que amealhava aos cofres públicos em 1913. O desempenho do imposto do selo não ocorreu sem manifestações dos empresários que reclamaram muito das intromissões do governo em seus negócios, assim como reclamaram da cobrança de tributos como rendas patrimoniais e industriais.

Os debates travados sobre as mudanças na tributação ficaram registrados na imprensa da época. No O Estado de S. Paulo, o governo foi criticado porque estava cobrando o imposto de consumo de forma abusiva, tanto que a arrecadação deste tributo já havia alcançado cifra $200 \%$ superior quando comparado aos exercícios fiscais de 1917 e 1914 . Outros pontos de reclamação foram em relação ao aumento da cota-ouro nos impostos de importação e por o governo estar cobrando em escala crescente diversos tributos em papel, sem conversibilidade 
garantida. ${ }^{163}$ Em debate ocorrido em 1917, durante reunião da Comissão de Finanças do Senado, Paulo de Frontin e Leopoldo de Bulhões discutiram sobre a possiblidade de extinção do imposto sobre os vencimentos dos funcionários públicos. Bulhões, senador por Goiás e partidário da estabilização monetária, explicou que as obrigações do funding loan não permitiriam ao governo abrir mão do tributo em questão porque mesmo com toda a arrecadação prevista o déficit fiscal era certo. ${ }^{164}$

A possibilidade de utilizar as mudanças tarifárias para direcionar a carga tributária para artigos supérfluos e isentando produtos considerados essenciais como o café foi motivo de argumentação exposta no Correio da Manhã, que comparou o tipo de tributação que se fazia avançar no Brasil com o que ocorria na Argentina, onde apenas produtos como álcool e fumo eram gravados, o que resultava em arrecadação adequada e sem prejuízo ao desenvolvimento econômico do país. ${ }^{165} \mathrm{O}$ problema é que não havia estrutura para colocar na ordem do dia elementos como progressividade da tributação ou neutralidade dos tributos. A sanha do governo por recursos não dava espaço para outras considerações que não a necessidade premente de diminuição do déficit público e foi por este motivo que o governo não pode aproveitar uma discussão bastante recorrente na primeira década republicana para mudar a dependência das finanças públicas para um tributo considerado “ideal”, que atendesse a demanda orçamentária sem prejudicar o sistema econômico, características identificadas no imposto de renda.

O tributo era conhecido na época principalmente pelo seu nome em inglês, income tax. O tributo vinha de experiência muito bem sucedida na Inglaterra e a noção de que um governo deveria depender essencialmente de impostos diretos e neutros começou a se espalhar pelo mundo. ${ }^{166}$ Como se pode observar na Tabela 4.9, o imposto sobre a renda até ensaiou um desempenho melhor durante a guerra, mas terminou o período representando muito pouco para o orçamento federal. Entre os motivos para a perda de importância nas receitas públicas está o fato de que a cobrança deste tributo era mais complexa do que a necessária para com o imposto de importação e com o imposto de consumo. Havia dificuldade da coletoria da época em enquadrar os contribuintes em faixas de renda e percentuais de lucro que suprissem as necessidades de financiamento do setor público, além do que era difícil garantir que estes

\footnotetext{
${ }^{163}$ O Estado de S. Paulo, 25 setembro 1918, p.6.

${ }^{164}$ O Estado de S. Paulo, 17 agosto 1917, p.4.

${ }^{165}$ Correio da Manhã, 16 novembro 1916, p. 2.

${ }^{166}$ O Estado de S. Paulo, 24 julho 1913, p.4.
} 
recursos fossem realmente recolhidos junto ao fisco porque o grau de evasão e de elisão fiscais eram elevados.

Tabela 4.9 - Imposto sobre a renda, valores orçados, Brasil, 1913-1919 (contos de réis)

\begin{tabular}{c|c|c}
\hline Exercício & Receita & $\begin{array}{c}\text { \% da Receita } \\
\text { Total }\end{array}$ \\
\hline 1913 & 6.106 & 1,7 \\
1914 & 7.106 & 2,0 \\
1915 & 21.725 & 7,5 \\
1916 & 26.720 & 8,0 \\
1917 & 23.870 & 7,3 \\
1918 & 13.910 & 3,3 \\
1919 & 6.610 & 1,4 \\
\hline
\end{tabular}

Tudo indicava que a solução para cobrir a redução na renda aduaneira seria o imposto sobre o consumo, mas esta solução não foi aceita tranquilamente pela sociedade. Houve quem defendesse o imposto de consumo antes mesmo de o tributo ter se transformado em um dos salvadores das finanças públicas por motivo alheio, mas bastante recorrente nas discussões orçamentárias durante a Primeira República: a falta de confiabilidade nos dados econômicos e financeiros. A ideia era utilizar o tributo sobre o consumo como instrumento para melhorar o grau de informação sobre a economia brasileira por meio de dados estatísticos. A falta de informações para a elaboração dos orçamentos era constantemente citada como um dos graves problemas da administração pública. Em matéria intitulada "A utilidade do imposto de consumo", o tributo conhecido à época como "imposto Murtinho" seria excelente para identificar de maneira mais precisa o desenvolvimento do comércio por meio do consumo e evitar estimativas equivocadas "em um país onde tudo se media a olho", como eram criticadas as estatísticas públicas ainda antes da guerra. ${ }^{167}$

O imposto de consumo passou a significar uma saída rápida e factível à ruptura do status quo representado pela queda da importância do imposto de importação. Em 1913, os principais produtos do imposto de consumo foram em ordem de importância tecidos, fósforos, bebidas, fumo e vinho estrangeiro. O fumo foi objeto de uma verdadeira luta do governo contra a sonegação, levando mesmo a uma ingerência pública na apuração do lucro dos fabricantes de tabaco, tudo com o propósito de assegurar uma receita que passou a ser importante demais para ser deixada sem regulamentação. A necessidade que o poder público

${ }^{167}$ O Imparcial, 27 abril 1913, p.5. 
passou a ter de encontrar substitutos ao imposto aduaneiro levou mesmo à tributação de estoques. O imposto do selo foi matéria de muita discussão a respeito dos limites de atuação do Estado: cobrar o tributo sobre mercadoria ainda não vendida era algo impensável na época. ${ }^{168}$ Este tributo foi uma das saídas para a substituição tributária que teve início durante a guerra: durante todo o período o gravame foi bastante significativo para os cofres públicos, principalmente quando a situação ficou mais crítica entre 1915 e 1918.

Como a situação internacional não dava sinais de melhora, com notícias que chegavam da Europa indicando que o cerco aos países declaradamente neutros estava se fechando, o governo foi instado a aumentar o leque de produtos passíveis do imposto de consumo. Em 1915, passaram a fazer parte da lista produtos como papel para forrar a casa, discos para gramofones e louças vidros, todos com arrecadação baixa, menor que 1\%, mas que já representam a mudança gradual que ocorreu no período. A ascensão do imposto de consumo se amplia em 1917, inclusive com a estreia de produtos como ferragens, manteiga e café torrado ou moído, artigos com consumo indicativo de aumento de urbanização e da renda. Uma questão que sobressaiu das análises foi que o grupo dos tecidos, apesar de ter sido destaque na abordagem historiográfica sobre a República Velha, não representou para o orçamento público durante a guerra o mesmo que representou para a economia brasileira em termos gerais. ${ }^{169}$ Artigos como fumo, bebidas e fósforos foram mais relevantes e mereceram mais atenção da Fazenda. Os três produtos foram citados diversas vezes na imprensa da época, sempre como sinônimo de indústrias tradicionais, consolidadas, e que poderiam absorver aumentos de impostos, principalmente o de consumo.

Tabela 4.10 - Imposto sobre o consumo, valores orçados, Brasil, 1914 (contos de réis)

\begin{tabular}{l|c|c|c}
\hline Imposto sobre o consumo & \multicolumn{3}{c}{ Papel } \\
\hline Fumo & & 8.000 & 2,3 \\
Bebidas, inclusive vinho de cana, frutas e & & 10.000 & 2,9 \\
semelhantes & & 10.000 & 2,9 \\
Fósforos & & 3.000 & 0,9 \\
Sal, tarifa reduzida a 10 réis/kg & & 2.100 & 0,6 \\
Calçado & & 425 & 0,1 \\
Velas & &
\end{tabular}

\footnotetext{
${ }^{168}$ Retrospecto Comercial - 1915, p.7.

${ }^{169}$ Versiani \& Versiani, “A industrialização brasileira antes de 1930: uma contribuição”, Formação econômica do Brasil, p. 123-41.
} 
Perfumarias

Especialidades farmacêuticas

Vinagre

Conservas

Cartas de jogar

Chapéus

Bengalas

Tecidos

Vinho estrangeiro

Total

Fonte: 1914. Lei 2.841, de 31 de dezembro de 1913.

$\begin{array}{cc}1.050 & 0,3 \\ 1.200 & 0,4 \\ 300 & 0,1 \\ 2.200 & 0,6 \\ 220 & 0,1 \\ 2.500 & 0,7 \\ 40 & 0,0 \\ 13.000 & 3,7 \\ 5.800 & 1,7 \\ 59.835 & 17,2\end{array}$

No último ano do conflito, o imposto sobre o consumo chegou a quase $30 \%$ de participação no orçamento total e a diversidade de produtos que passaram a recolher o produto aumentou significativamente com a inclusão de artigos típicos de consumo urbano, como observado na Tabela 4.10. De acordo com Warren Dean, a guerra contribuiu para o aumento no consumo de produtos nacionais não apenas devido à interrupção no fluxo do comércio internacional, mas também porque ensejou a redução no preconceito que a elite tinha em relação a produtos manufaturados no Brasil. ${ }^{170}$ Muitos artigos recebiam ainda rótulos enganosos, com a menção de lugares europeus famosos, como se a origem do produto fosse estrangeira. ${ }^{171}$ De qualquer forma isto não deixou de representar uma oportunidade, pontual e passageira, para a indústria local. Os dados contidos nas Tabelas 4.10 e 4.11 sobre o imposto de consumo indicam que as indústrias mais expressivas no período foram as de fumo, bebidas, fósforos e tecidos. Considerados apenas os valores para o consumo de tecidos, notase como o setor foi importante para a economia brasileira durante a Primeira Guerra.

Tabela 4.11 - Imposto sobre o consumo, valores orçados, Brasil, 1918 (contos de réis)

\begin{tabular}{l|c|c|c}
\hline Imposto sobre o consumo & \multicolumn{3}{c}{ Papel } \\
\hline Fumo & & 20.000 & 4,7 \\
Bebidas, inclusive vinho de cana, frutas & & 31.000 & 7,2 \\
e semelhantes & & 17.000 & 4,0 \\
Fósforos & & 5.500 & 1,3 \\
Sal & & 4.500 & 1,0 \\
Calçado & & 500 & 0,1 \\
Velas & & 2.500 & 0,6 \\
Perfumarias & & 2.000 & 0,5 \\
Especialidades farmacêuticas & & 400 & 0,0 \\
Vinagre & & & \\
& & & \\
170 Dean, A industrialização de São Paulo, 1880-1945, capítulo VI. & & \\
171 Para exemplo de produtos que exaltavam elementos europeus, ver: Piccarolo; Finochi, O desenvolvimento \\
industrial de S. Paulo através da Primeira Exposição Municipal, p. 191-3.
\end{tabular}


Conservas

$\begin{array}{cc}4.650 & 1,1 \\ 450 & 0,1 \\ 3.450 & 0,8 \\ 30 & 0,0 \\ 22.400 & 5,2 \\ 40 & 0,0 \\ 3.600 & 0,8 \\ 50 & 0,0 \\ 35 & 0,0 \\ 600 & 0,1 \\ 500 & 0,1 \\ 1.800 & 0,4 \\ 500 & 0,1\end{array}$

Cartas de jogar

Chapéus - elevadas as taxas de $50 \%$

Bengalas

Tecidos

5,2

Espartilhos

Vinho estrangeiro

Papel para forrar casa

0,0

Discos para gramofones

Louças e vidros

0,1

Ferragens

0,1

Café torrado ou moído

Manteiga em latas, frascos ou outros envoltórios

Fonte: Receita Geral da República do Brasil para o exercício de 1918. Lei 3446 - de 31 de dezembro de 1917.

A importância do imposto de consumo junto à coletoria federal teve como base a capacidade de arrecadação do tributo frente aos valores orçados. Somente nos dois exercícios 1914 e 1918 a arrecadação foi inferior aos valores orçados, como indica a Tabela 4.12. Foram diferenças pequenas e totalmente explicáveis pelas condições adversas trazidas pela guerra.

Tabela 4.12 - Impostos sobre o consumo, valores orçados e arrecadados, Brasil, 1913-1919 (contos de réis)

Imposto sobre o consumo

Papel

\begin{tabular}{c|c|c|c|c}
\multicolumn{1}{c}{ Orçamento } & \multicolumn{1}{c}{ Arrecadação } & \multicolumn{1}{c}{ Diferença } & $\%$ \\
\hline 1913 & 59.955 & 65.143 & 5.188 & 8,7 \\
1914 & 59.835 & 52.223 & -7.611 & $-12,7$ \\
1915 & 61.490 & 67.936 & 6.446 & 10,5 \\
1916 & 71.146 & 83.828 & 12.682 & 17,8 \\
1917 & 102.578 & 117.720 & 15.142 & 14,8 \\
1918 & 121.505 & 119.719 & -1.786 & $-1,5$ \\
1919 & 131.180 & 131.861 & 681 & 0,5 \\
Média & $86.812,8$ & 91.204 & 4.391 & 0,05 \\
\hline
\end{tabular}

Fonte: Ministério da Agricultura, Indústria e Comércio, Receitas, despesas e dívidas públicas da União, Estados e Municípios, 1926. Anexo, p.6.

Os recursos provenientes das rendas industriais eram compostos por receitas provenientes do correio geral, dos telégrafos, da imprensa nacional e do diário nacional, de estradas de ferro, de consulados, entre outros, como se pode verificar na Tabela 4.13. Em relação ao orçamento para valores não conversíveis, os destaques ficam para a renda da 
Estrada de Ferro Central do Brasil, do Correio Geral e dos Telégrafos. Os outros recursos representaram menos que $1 \%$ do orçamento de 1913. No ano de 1915 já se faziam sentir os efeitos da guerra e a busca por novas receitas se intensificou, fazendo o peso das rendas industriais aumentarem para 21,2\%, com participação ainda maior da Central do Brasil, do Correio Geral, dos Telégrafos e da Estrada de Ferro Oeste de Minas. A partir deste exercício e até o final do período pesquisado, a participação das rendas industriais diminui, mas permaneceu como responsável por mais de 1/5 das receitas em papel. Como mostra a Tabela 4.14, a grande novidade ficou reservada para o exercício de 1918 porque foi registrada a contribuição que o arrendamento de navios do Lloyd proporcionou para o orçamento em ouro: $33,8 \%$, ou $62,5 \%$ do valor esperado com a arrecadação do imposto de importação. Estes recursos tiveram origem na extensa e traumática negociação que o governo brasileiro travou com o governo francês sobre a utilização da frota nacional nas operações de comércio marítimo ao fim da guerra.

Vale lembrar que o imposto de circulação era um grupo que incluía o imposto do selo e o imposto de transporte, com predomínio do imposto do selo como o mais representativo, tendo representado para todo o período sempre mais de $60 \%$ do total orçado para cada um dos exercícios. ${ }^{172}$ Esta mudança pode ser um indicativo dos efeitos da guerra sobre o imposto do selo que já era considerado um dos mais tradicionais e que passa a dividir importância com o imposto de transporte, tributo com características de economia mais urbana.

\footnotetext{
${ }^{172}$ Retrospecto Comercial, 1914, p. 118.
} 
Tabela 4.13 - Rendas industriais e valores orçados, Brasil, 1914 (contos de réis, ouro e papel)

\begin{tabular}{|c|c|c|c|c|}
\hline Rendas Industriais & Ouro & $\%$ & Papel & $\%$ \\
\hline Renda do Correio Geral & & & 9.000 & 2,6 \\
\hline Renda dos Telégrafos & 500 & 0,5 & 6.200 & 1,8 \\
\hline $\begin{array}{l}\text { Renda da Imprensa Nacional e Diário } \\
\text { Oficial }\end{array}$ & & & 300 & - \\
\hline $\begin{array}{l}\text { Renda da Estrada de Ferro Central do } \\
\text { Brasil }\end{array}$ & & & 36.000 & 10,5 \\
\hline Renda da Estrada de Ferro Oeste de Minas & & & 4.000 & 1,2 \\
\hline Renda da Estrada de Ferro do Rio do Ouro & & & 160 & _. \\
\hline $\begin{array}{l}\text { Renda do Ramal Férreo de Lorena à } \\
\text { Piquete }\end{array}$ & & & 20 & - \\
\hline Renda Casa da Moeda & & & 20 & - \\
\hline Renda dos Arsenais & & & 10 & - \\
\hline $\begin{array}{l}\text { Renda dos Institutos dos Surdos, Mudos e } \\
\text { dos Meninos Cegos }\end{array}$ & & & 10 & - \\
\hline Renda dos Colégios Militares & & & 250 & - \\
\hline Renda da Casa de Correção & & & 10 & - \\
\hline Renda Arrecadada nos Consulados & 1.600 & 1,5 & & \\
\hline Renda da Assistência a Alienados & & & 140 & - \\
\hline $\begin{array}{l}\text { Renda do Laboratório Nacional de } \\
\text { Análises }\end{array}$ & & & 200 & - \\
\hline $\begin{array}{l}\text { Contribuição das companhias ou empresas } \\
\text { de estradas de ferro, das companhias de } \\
\text { seguros, nacionais ou estrangeiras }\end{array}$ & & & 2.300 & 0,7 \\
\hline Total & 2.100 & 2,0 & 58.680 & 16,9 \\
\hline
\end{tabular}

Fonte: Lei orçamentária para o exercício de 1914, Receita Geral da República do Brasil para o exercício de 1914. Lei 2.841, de 31 de dezembro de 1913.

O exercício de 1918 sintetizou os esforços empreendidos pelo governo federal em tentar diversificar as fontes de arrecadação para o grupo de rendas industriais, como é o caso das estradas de ferro que passam a contar com praticamente o dobro de fontes de receitas em relação a 1914, conforme mostra a Tabela 4.14. Mesmo que estas novas linhas de orçamento tivessem baixa representatividade para o orçamento total, chama a atenção o fato de ter sido possível aumentar os investimentos em logística e consequentemente a arrecadação em um momento tão adverso. 
Tabela 4.14 - Rendas Industriais, valores orçados, Brasil, 1918 (contos de réis, ouro e papel)

\begin{tabular}{|c|c|c|c|c|}
\hline Rendas Industriais & Ouro & $\%$ & Papel & $\%$ \\
\hline Renda do Correio Geral & & & 10.000 & 2,3 \\
\hline Renda dos Telégrafos & 800 & 0,7 & 9.500 & 2,2 \\
\hline $\begin{array}{l}\text { Renda dos Telégrafos - acréscimo de } \\
\text { taxas }\end{array}$ & & & & \\
\hline $\begin{array}{l}\text { Renda da Imprensa Nacional e Diário } \\
\text { Oficial }\end{array}$ & & & 500 & 0,1 \\
\hline $\begin{array}{l}\text { Renda da Estrada de Ferro Central do } \\
\text { Brasil }\end{array}$ & & & 62.500 & 14,6 \\
\hline $\begin{array}{l}\text { Renda da Estrada de Ferro Oeste de } \\
\text { Minas }\end{array}$ & & & 5.000 & 1,8 \\
\hline $\begin{array}{l}\text { Renda da Estrada de Ferro do Rio do } \\
\text { Ouro }\end{array}$ & & & 190 & 0,0 \\
\hline $\begin{array}{l}\text { Renda da Estrada de Ferro Itapura a } \\
\text { Corumbá }\end{array}$ & & & 1.000 & 0,2 \\
\hline $\begin{array}{l}\text { Renda do Ramal Férreo de Lorena à } \\
\text { Piquete }\end{array}$ & & & 25 & 0,0 \\
\hline Renda Casa da Moeda & & & 20 & 0,0 \\
\hline Renda dos Arsenais & & & 12 & 0,0 \\
\hline $\begin{array}{l}\text { Renda dos Institutos dos Surdos, Mudos } \\
\text { e dos Meninos Cegos }\end{array}$ & & & 2 & 0,0 \\
\hline Renda dos Colégios Militares & & & 20 & 0,0 \\
\hline Renda da Casa de Correção & & & 3 & 0,0 \\
\hline Renda Arrecadada nos Consulados & 1.000 & 0,9 & & \\
\hline Renda da Assistência a Alienados & & & 100 & 0,0 \\
\hline $\begin{array}{l}\text { Renda do Laboratório Nacional de } \\
\text { Análises }\end{array}$ & & & 120 & 0,0 \\
\hline Renda da Rede de Viação Cearense & & & 3.000 & 0,7 \\
\hline $\begin{array}{l}\text { Contribuição das companhias ou } \\
\text { empresas de estradas de ferro, das } \\
\text { companhias de seguros, nacionais ou } \\
\text { estrangeiras }\end{array}$ & & & 1.800 & 0,4 \\
\hline $\begin{array}{l}\text { Minas de carvão de Jacuí - dividendo de } \\
\text { ações }\end{array}$ & & & 500 & 0,1 \\
\hline Arrendamento de navios do Lloyd & 38.863 & 33,8 & & \\
\hline Total & 40.663 & 35,4 & 94.392 & 22,0 \\
\hline
\end{tabular}

Fonte: Lei orçamentária para o exercício de 1918, Receita Geral da República do Brasil para o exercício de 1918. Lei 3446 - de 31 de dezembro de 1917.

Os orçamentos para as despesas durante o período pesquisado alocavam recursos para cada um dos sete ministérios e dentro das verbas dos ministérios definia a distribuição dos valores para itens como despesa com pessoal, manutenção de instituições e bens públicos, compra de materiais, obras, aluguéis, entre outros. 
Os maiores orçamentos em ouro para o período foram do Ministério da Fazenda, com percentuais sempre representando mais da metade de todo o orçamento da União. Em parte do período, de 1913 a 1915, a pasta recebeu ainda verba adicional que fez o seu orçamento representar aproximadamente $80 \%$ do valor total. 1916 foi o ano de maior alocação de recursos diretos para esta pasta e sem o repasse de renda especial, o percentual ficou em $83,5 \%$ do orçamento. Para uma economia essencialmente concentrada no setor externo, o Ministério da Fazenda já demonstrava poder controlando quase todos os gastos públicos em moeda forte. Apesar de os valores em ouro dependerem em alto grau do desempenho do setor primário não era a pasta da agricultura a mais poderosa na política pública brasileira durante a Primeira Guerra Mundial, como se pode observar na Tabela 4.15 que registra a situação dos ministérios frente aos gastos totais para o ano inicial da guerra. Logo após a Fazenda, a pasta com maior força no governo Wenceslau Braz foi a da Viação e Obras Públicas por conta das estradas de ferro que atraíam investimentos estrangeiros e eram grande motivo dos empréstimos em moeda forte realizados pela União.

Em razão de todos os investimentos que se realizavam no transporte ferroviário, esta pasta também se destacava no orçamento em papel, chegando mesmo a ser mais importante que a da Fazenda, como mostram os dados na Tabela 4.15. Na sequência em grau de poder financeiro vinha o Ministério da Guerra com orçamento irrelevante em ouro, mas que em papel era contemplado com parcelas que representavam sempre mais de $15 \%$ dos recursos totais. Por se tratar de período de guerra chama atenção o fato de não ter havido nenhuma mudança no repasse de valores nem para esta pasta, nem para a da Marinha, que manteve sua participação em torno de $9 \%$ do orçamento total para cada um dos exercícios. Mas quando se verifica que a Primeira Guerra Mundial não alterou em praticamente nada a alocação de recursos para os ministérios mais diretamente envolvidos com o conflito, pode-se deduzir que as necessidades que estes recursos tentavam atender eram de caráter essencialmente doméstico, como a Guerra do Contestado e a Revolta dos Marinheiros. 
Tabela 4.15 - Despesas Gerais, valores orçados, Brasil, 1914 (contos de réis, ouro e papel)

\begin{tabular}{|c|c|c|c|c|}
\hline Ministério & Ouro & $\%$ & Papel & $\%$ \\
\hline Justiça e Negócios Interiores & 15 & - & 47.552 & 10,9 \\
\hline Viação e Obras Públicas & 10.662 & 11,2 & 124.160 & 28,5 \\
\hline Fazenda & 52.619 & 55,1 & 108.971 & 25,0 \\
\hline Fazenda - Renda Especial & 25.290 & 26,5 & 14.850 & 3,4 \\
\hline Relações Exteriores & $2.936,99$ & 3,1 & 2.340 & 0,5 \\
\hline Marinha & 2.900 & 3,0 & 42.155 & 9,7 \\
\hline Guerra & 250 & 0,3 & 71.979 & 16,5 \\
\hline Agricultura, Indústria e Comércio & 797 & 0,8 & 23.767 & 5,5 \\
\hline Total & 95.470 & 100,0 & 435.773 & 100,0 \\
\hline
\end{tabular}

Fonte: Lei orçamentária para o exercício de 1914, Fixa a despesa geral da República dos Estados Unidos do Brasil para o exercício de 1914. Lei 2,842 - de 03 de janeiro de 1914.

Ao longo do período da guerra, os dois únicos ministérios que tiveram os orçamentos sensivelmente alterados foram os da Fazenda e o da Viação e Obras Públicas, como espelha a Tabela 4.16. Os Ministérios da Justiça e Negócios Interiores e o das Relações Exteriores praticamente não tiveram alterações orçamentárias, o que é interessante de se observar porque o da Justiça e Negócios Interiores deveria ter refletido as despesas dos grandes acontecimentos que foram as greves de 1917 e a Gripe Espanhola verificados neste mesmo ano. O Ministério das Relações Exteriores também não recebeu verba adicional, apesar de a situação na Europa ter se radicalizado e os interesses do país terem sido ameaçados, especialmente após a entrada em vigor da Statutory List, lista de exceções imposta pelos países da Entente para o comércio internacional.

Tabela 4.16 - Despesas Gerais, valores orçados, Brasil, 1918 (contos de réis, ouro e papel)

\begin{tabular}{l|c|c|c|c}
\hline Ministério & Ouro & $\%$ & \multicolumn{1}{c}{ Papel } & $\%$ \\
\hline Justiça e Negócios Interiores & 12 & - & 48.693 & 10,5 \\
Viação e Obras Públicas & 30.003 & 35,5 & 148.307 & 32,1 \\
Fazenda & 50.828 & 60,2 & 126.088 & 27,3 \\
Relações Exteriores & 2.697 & 3,2 & 1.107 & 0,3 \\
Marinha & 200 & 0,2 & 44.313 & 9,6 \\
Guerra & 100 & 0,1 & 74.498 & 16,1 \\
Agricultura, Indústria e Comércio & 617 & 0,7 & 18.953 & 4,1 \\
Total & 84.456 & 100,0 & 461.959 & 100,0 \\
\hline
\end{tabular}

Fonte: Lei orçamentária para o exercício de 1918, Fixa a despesa geral da República dos Estados Unidos do Brasil para o exercício de 1918. Lei 3.454- de 06 de janeiro de 1919. 
A preocupação com o desempenho do governo na administração das contas públicas fica patente mesmo antes da guerra em relatos da época que testemunham que a crise financeira na Europa afetou o Brasil. Questões internas contribuíram para não permitir que a situação voltasse ao normal no país, mesmo após a economia europeia ter emitido sinais de retomada das atividades regulares já em 1913. O maior entrave foi causado pelo não pagamento de compromissos do governo junto ao comércio local que ainda era constituído principalmente por empresários nascidos fora do Brasil, o que contribuiu para alimentar o pessimismo do mercado internacional nas relações com o Brasil e manteve a retração de recursos em moeda forte ao país. Com oferta reduzida de moeda conversível, a economia doméstica não demorou muito para perceber a falta de horizontes e ver a crise aprofundar. ${ }^{173}$ Importante notar como a economia do setor público influenciava o setor privado, principalmente por meio do abandono de forma cada vez mais nítida da disciplina monetária e a volta das emissões inconversíveis. Não somente os investidores internacionais, mas o próprio mercado brasileiro era bastante crítico com relação a medidas relacionadas à composição da dívida externa.

Houve déficit nas contas públicas em todos os anos da guerra, como atesta a Tabela 4.17. Os déficits já eram esperados devido à redução na renda aduaneira, mas o fato de as despesas terem praticamente permanecido no mesmo patamar do observado antes da guerra mostra a situação de descontrole orçamentário do governo Wenceslau Braz. As despesas não foram reduzidas na mesma proporção do que ocorreu com as receitas e até aumentaram em comparação ao ano anterior à guerra especialmente a partir de 1917, o que elevou os déficits para proporções muito além do esforço de aumento das receitas. Se a arrecadação com o imposto de importação tivesse voltado ao que ocorria antes da guerra o déficit ainda assim teria sido elevado.

Tabela 4.17 - Receitas e despesas efetivas da União, 1913- 1919 (contos de réis)

\begin{tabular}{|c|c|c|c|c|}
\hline Exercício & Receitas & Despesas & Saldo ou Déficit & $\begin{array}{c}\text { Déficit } \\
(1913=\text { base 100) }\end{array}$ \\
\hline 1913 & 654.391 & 762.945 & -108.554 & 100 \\
\hline 1914 & 423.252 & 759.914 & -336.662 & 310 \\
\hline 1915 & 485.599 & 688.582 & -202.983 & 187 \\
\hline 1916 & 477.897 & 686.558 & -208.661 & 192 \\
\hline 1917 & 537.441 & 801.447 & -264.006 & 243 \\
\hline 1918 & 618.830 & 867.162 & -248.332 & 229 \\
\hline 1919 & 625.693 & 931.579 & -305.886 & 282 \\
\hline
\end{tabular}

$\overline{173}$ Retrospecto Comercial 1913, p. 5. 
Fonte: Ministério da Agricultura, Indústria e Comércio, Resumo de várias estatísticas econômico-financeiras, 1924, p.131.

Para cobrir os déficits em moeda local o governo aumentava a dívida interna utilizando a emissão de apólices que eram destinadas ao pagamento de construção de estradas de ferro, pagamento de trabalhos de saneamento, repasses extraordinários aos ministérios, entre outros propósitos ${ }^{.174}$

A construção de vias férreas era de suma importância para as finanças públicas do Brasil não porque representassem a promoção de uma melhor integração logística nacional, mas sim porque a aprovação de projetos e a busca de financiamentos indicavam que seriam liberados recursos que abasteceriam as receitas públicas, dando fôlego às despesas já previstas e não cobertas dos orçamentos.

Os valores envolvidos no negócio de construção e encampação de estradas de ferro eram muito elevados, como ocorreu em 1914 quando atingiram 44.062:475\$995, ou o equivalente à metade do orçamento para o exercício. Além de custoso, o negócio estradas de ferro era complexo e envolvia interesses internos e externos que ultrapassavam em muito a preocupação em sanar o problema da logística. Em termos internos, significava a movimentação de recursos que agradavam os estados mais poderosos, como São Paulo, Minas Gerais e Rio de Janeiro, estados que dependiam das exportações como a principal fonte para a geração de renda pública e privada. As estradas de ferro representavam a inserção mais completa do Brasil na divisão internacional do trabalho, basicamente porque os empreendimentos eram de valor elevado e orçados em moeda forte que deveria ser tomada por meio de empréstimo no exterior, geralmente com apoio dos banqueiros ligados à Casa Rothschild. Estes recursos eram repassados em moeda local aos empreendimentos, mas o governo engordava o orçamento no seu ponto mais vulnerável, a aquisição de moeda conversível. Esta situação deixava as contas públicas em um ciclo vicioso porque a aparente calma no setor externo provocada pela entrada de recursos estrangeiros era o combustível de crises futuras dado que estes recursos aumentavam os gastos públicos e provocavam mais dívida interna que somada à dívida externa deixava o país sempre à beira da insolvência. ${ }^{175} \mathrm{~A}$ guerra potencializou estes problemas ao reduzir o preço do café no mercado internacional.

\footnotetext{
${ }^{174}$ Mensagem apresentada ao Congresso Nacional, 1913, p. 137; Mensagem apresentada ao Congresso Nacional, 1916, p. 134.

${ }^{175}$ Mensagem apresentada ao Congresso Nacional, 1915, p. 74.
} 
A solução teria que vir na forma de uma dependência maior do mercado interno em relação ao setor externo da economia, uma das consequências da Primeira Guerra Mundial. O problema foi que a guerra provocou aumento substancial no valor do frete internacional, dificultando em muito a aquisição de carvão, produto essencial para a indústria da época. ${ }^{176}$ Obstáculo de difícil solução foram as restrições que o Reino Unido e a França impuseram ao comércio mundial como a de que os países neutros somente poderiam importar quantidades e tipos de produtos de acordo com médias anteriores a 1914, situação que afetou a economia brasileira porque houve queda na renda aduaneira e falta de insumos e bens de produção para a indústria nacional. ${ }^{177}$

Estes obstáculos foram somados a outros já conhecidos pela administração pública brasileira e levaram a mudanças no discurso do governo. Ações moralizadoras entraram nos discursos oficiais que defendiam maior cuidado com os orçamentos. ${ }^{178}$ Apesar da ênfase como a questão dos desequilíbrios orçamentários passou a ser tratada, a austeridade não foi marca da administração Wenceslau Braz, como o fora o período de ortodoxia implantado por Joaquim Murtinho na primeira década republicana. Findo o governo em 1918, os pronunciamentos de Delfim Moreira voltaram a abordar os mesmos pontos de orçamentos que já nasciam deficitários e pioravam ao longo dos exercícios, deixando o governo em crise permanente. ${ }^{179}$

A guerra deixou ao menos uma marca no poder público brasileiro que foi a de ressaltar a necessidade de reforma nas tarifas alfandegárias e da modernização da carga tributária que deveria passar a depender mais de tributos como o imposto de consumo e o imposto de renda. Estas ações tiveram origem exógena porque partiram da premissa que a dívida externa e o pagamento de juros em moeda conversível necessitavam de uma fonte de recursos com caráter arrecadador mais fiscal do que o que o imposto de importação havia proporcionado até o advento da guerra. ${ }^{180}$

Se em termos de receitas a fatia da União diminuiu ao longo da guerra em comparação aos estados e municípios, o mesmo não ocorreu no quesito das despesas. Como mostra a Tabela 4.18, entre 1913 e 1919 os gastos orçados do governo federal ficaram por volta de

\footnotetext{
${ }^{176}$ Mensagem apresentada ao Congresso Nacional, 1916, p. 7.

${ }^{177}$ Mensagem apresentada ao Congresso Nacional, 1916, p.13.

${ }^{178}$ Mensagem apresentada ao Congresso Nacional, 1917, p.7.

${ }^{179}$ Mensagem apresentada ao Congresso Nacional, 1919, p. 24

${ }^{180}$ Mensagem apresentada ao Congresso Nacional, 1919, p. 26
} 
$60 \%$ do total das despesas efetivamente realizadas, indicando que o esforço para a redução de gastos públicos não correspondeu à retórica.

Tabela 4.18 - Despesa da União, dos Estados e dos Municípios, 1913-1919 (contos de réis)

\begin{tabular}{ccccccccc}
\hline & \multicolumn{3}{c}{ Despesa realizada } & Total & \multicolumn{2}{c}{ Porcentagem } & $\begin{array}{c}\text { Números- } \\
\text { índices do } \\
\end{array}$ \\
& União & Estados & Municípios & & União & Estados & Municípios & total \\
\hline 1913 & 763 & 291 & 147 & 1.201 & 63 & 24 & 12 & 100 \\
1914 & 760 & 266 & 139 & 1.165 & 65 & 23 & 12 & 97 \\
1915 & 689 & 251 & 151 & 1.090 & 63 & 23 & 14 & 91 \\
1916 & 687 & 259 & 152 & 1.098 & 63 & 24 & 14 & 91 \\
1917 & 801 & 283 & 153 & 1.237 & 65 & 23 & 12 & 103 \\
1918 & 867 & 310 & 161 & 1.338 & 65 & 23 & 12 & 111 \\
1919 & 932 & 336 & 217 & 1.485 & 63 & 23 & 15 & 124 \\
\hline
\end{tabular}

Fonte: Ministério da Agricultura, Indústria e Comércio, Resumo de várias Estatísticas Econômico-Financeiras, 1924, p. 130.

Outra maneira ilustrativa de examinar a administração das finanças públicas é por meio dos orçamentos e despesas efetivas do Ministério da Fazenda que foi o mais importante para os orçamentos durante a guerra. A Tabela 4.19 mostra os valores orçados e as despesas realizadas em ouro na qual se verifica que os déficits do ministério ficaram dentro de um intervalo aceitável, com percentual máximo de $15,2 \%$ de diferença entre valores orçados e efetivamente gastos.

Tabela 4.19 - Discriminação da despesa da União, 1913-1919, segundo os diversos Ministérios (contos de réis em papel) - Fazenda (contos de réis em ouro)

\begin{tabular}{|c|c|c|c|c|c|c|}
\hline & \multicolumn{6}{|c|}{ Fazenda } \\
\hline & $\begin{array}{c}\text { Orçamento } \\
\text { ouro }\end{array}$ & $\begin{array}{c}\text { Renda } \\
\text { especial }\end{array}$ & Total & $\begin{array}{c}\text { Despesa } \\
\text { ouro }\end{array}$ & Diferença & $\%$ \\
\hline 1913 & 44.685 & 23.260 & 67.945 & 62.489 & -5.456 & $-8,0$ \\
\hline 1914 & 52.619 & 25.290 & 77.909 & 66.064 & -11.845 & $-15,2$ \\
\hline 1915 & 40.824 & 16.115 & 56.938 & 57.126 & 187 & 0,3 \\
\hline 1916 & 70.423 & 0,0 & 70.423 & 60.439 & -9.984 & $-14,2$ \\
\hline 1917 & 73.653 & 0,0 & 73.653 & 70.875 & -2.778 & $-3,8$ \\
\hline 1918 & 50.828 & 0,0 & 50.828 & 49.351 & -1.477 & $-2,9$ \\
\hline 1919 & 48.829 & 0,0 & 48.829 & 48.068 & -760 & $-1,6$ \\
\hline
\end{tabular}

Fonte: Ministério da Agricultura, Indústria e Comércio, Receitas, despesas e dívidas públicas da União, Estados e Municípios, 1926, Anexo, VI p.8.

Quando a análise é feita sobre o orçamento em papel, a Tabela 4.20 mostra que as diferenças entre os recursos que a Fazenda poderia gastar e o que realmente ocorreu foram a melhor prova de como agiu a administração Wenceslau Braz na questão fiscal. Com exceção do exercício de 1916, em todos os outros anos os gastos foram bastante superiores ao orçado, 
principalmente em 1917 e 1918 quando a situação da arrecadação ainda estava longe de se normalizar e o rombo no orçamento passou de 70\%. Especialmente em 1917, o principal motivo para exorbitância de gastos extraordinários foram as contas de juros e amortização de empréstimos internos, indicando quanto o poder executivo já dependia do setor interno da economia para atender as necessidades de financiamento.

Tabela 4.20 - Discriminação da despesa da União Federal realizada, 1913-1919, segundo os diversos ministérios (contos de réis)

\begin{tabular}{|c|c|c|c|c|c|c|}
\hline & \multicolumn{6}{|c|}{ Fazenda } \\
\hline & $\begin{array}{l}\text { Orçamento } \\
\text { papel }\end{array}$ & $\begin{array}{l}\text { Renda } \\
\text { especial }\end{array}$ & Total & Despesa papel & Diferença & $\%$ \\
\hline 1913 & 119.010 & 12.850 & 131.860 & 175.787 & -43.927 & $-33,3$ \\
\hline 1914 & 108.971 & 14.850 & 123.821 & 193.509 & -69.688 & $-56,3$ \\
\hline 1915 & 101.831 & 21.530 & 123.361 & 165.812 & -42.451 & $-34,4$ \\
\hline 1916 & 124.596 & 21 & 124.617 & 133.047 & -8.430 & $-6,8$ \\
\hline 1917 & 123.875 & 0,0 & 123.875 & 218.942 & -95.066 & $-76,7$ \\
\hline 1918 & 126.088 & 0,0 & 126.088 & 221.546 & -95.458 & $-75,7$ \\
\hline 1919 & 125.840 & 0,0 & 125.840 & 160.621 & -34.781 & $-27,6$ \\
\hline
\end{tabular}

Fonte: Ministério da Agricultura, Indústria e Comércio, Receitas, despesas e dividas públicas da União, Estados e Municípios, 1926, anexo, VI p.8.

As finanças públicas do Brasil não vinham de uma situação equilibrada antes mesmo do início da guerra. A única tentativa séria e que chegou mais próxima de um acordo para disciplinar as contas fiscais foi a empreendida por Joaquim Murtinho no início do século. O Governo de Wenceslau Braz começou indicando ao mercado e à sociedade que seguiria os passos de Hermes da Fonseca em termos fiscais e o país continuaria a apresentar déficits públicos, com o orçamento mantendo a cômoda dependência da renda aduaneira.

Conclusão

A Primeira Guerra Mundial modificou a maneira pela qual o Brasil atuava na economia internacional. Esta modificação significou redução nos valores transacionados no comércio exterior, principalmente nas importações. Valor importado menor significou redução na arrecadação do imposto de importação, que era a base dos orçamentos públicos. Apesar desta situação de restrição orçamentária, as despesas não foram reduzidas. Os países europeus estavam entesourando ouro desde a eclosão das guerras balcânicas, o que dificultava o acesso a empréstimos internacionais.

Era um cenário de exceção, característico de choque adverso. Apesar disto, a guerra não teve força suficiente para alterar as bases da economia brasileira. As mudanças foram 
circunstanciais. O imposto sobre o consumo foi usado como substituto às rendas aduaneiras. O problema foi que o imposto de importação fornecia também receita na forma da quota-ouro, possibilidade inexistente para o tributo sobre o consumo. Se o déficit brasileiro fosse em moeda não conversível, parte do problema estaria resolvido.

O que ficou de positivo desta experiência na administração dos orçamentos públicos foi a constatação de que o país não poderia continuar dependendo de um tributo cujo fato gerador era externo. A crise orçamentária abriu debates sobre a necessidade de reforma tributária. O Congresso chegou a discutir a possibilidade de ampliação do imposto sobre a renda. Estas discussões tiveram a colaboração de João Pandiá Calógeras, ministro da Fazenda que teve como incumbência encontrar caminhos que possibilitassem condições de governabilidade em um mundo avesso ao risco. As propostas e as experiências de Calógeras na economia brasileira são o tema do próximo capítulo. 


\section{Capítulo 5 - Ministério da Fazenda - período Pandiá Calógeras}

João Pandiá Calógeras foi o ministro da Fazenda que por mais tempo comandou a pasta durante a Primeira Guerra Mundial. Foram mais de dois anos à frente de um ministério que teve que se transformar para atender as novas demandas trazidas pelos conflitos na Europa. A passagem de Calógeras pela Fazenda se traduziu em estudos e práticas que fizeram de maneira efetiva diminuir a dependência do orçamento brasileiro das rendas aduaneiras. Calógeras se baseou em princípios tributários europeus para indicar caminhos que a receita do Brasil deveria perseguir.

O ministro da Fazenda era grande entusiasta da diversificação também na pauta de exportações do Brasil. Calógeras estruturou um departamento com o intuito de divulgar os produtos brasileiros no exterior. Muitas negociações que saíram dos padrões até então seguidos pelo Brasil no comércio internacional foram incentivadas por Calógeras.

O ministro era grande conhecedor do território brasileiro, habilidade que conquistou ao desempenhar suas funções de geólogo. Nestas investidos pelo interior do Brasil, Calógeras identificou os muitos gargalos que impediam a produção brasileira de chegar aos mercados consumidores. Na análise do ministro, a guerra não era a única responsável pelos transtornos logísticos que o Brasil enfrentava. O transporte de cabotagem deveria ser incentivado para permitir que riquezas naturais do Brasil alcançassem compradores estrangeiros.

Para melhorar a eficiência da economia brasileira, Calógeras propôs a criação de uma empresa de navegação que atendesse aos interesses do Brasil e dos vizinhos na América do Sul. Para equipar esta empresa, Calógeras centrou esforços nas negociações que permitiriam ao Brasil tomar posse dos navios alemães que estavam ancorados nos portos brasileiros quando do início da guerra.

O perfil inovador de Calógeras não agradou a sociedade brasileira como um todo. $\mathrm{O}$ ministro acabou provocando desavenças sérias com o comércio importador quando insistiu no aumento da cobrança da quota-ouro e na ampliação da eficiência de arrecadação federal. No setor externo, as relações do ministro com os credores internacionais alteraram elogios pela disposição em mudanças com críticas ao modo pelo qual ele conduziu o arresto dos navios alemães. 
Seção 5.1 - A administração do Ministério da Fazenda durante a guerra.

Foram três os ministros da Fazenda do Brasil durante a Primeira Guerra Mundial: Sabino Alves Barroso Júnior, João Pandiá Calógeras e Antônio Carlos Ribeiro de Andrada. Sabino Barroso, ministro da Fazenda, da Justiça e dos Negócios Interiores em governos anteriores, teve curta passagem no governo de Wenceslau Braz. Foram apenas seis meses, de 15/11/1914 a 31/05/1915, mas a fama de Barroso o precedia e o mercado já esperava que houvesse por parte do primeiro mandatário da Fazenda do novo governo muita resistência à volta da emissão sem lastro, solução que muitos empresários entendiam como a única possível para enfrentar a crise que se instalara desde 1913. Eles não pouparam esforços em fazer esta opinião chegar de todas as maneiras ao Palácio do Catete. Este é um ponto que causa estranheza por que muitos não esperavam que a escolha de Wenceslau Braz recaísse sobre um nome que era contrário ao abandono da disciplina monetária e fiscal. A experiência anterior de Barroso na Fazenda já o havia colocado na linha de fogo das associações comerciais, ávidas por alívio no crédito e contrárias à cobrança do imposto sobre o consumo, tributo de predileção de Barroso que ele não tardou em aplicar à economia brasileira naquele final de $1914 .^{181}$

Neste período de início da guerra, o comércio também estava em luta aberta contra os bancos que se recusavam a aceitar valores elevados em moedas de prata e níquel, meios de pagamento que ganharam força no comércio devido à falta de numerário. ${ }^{182} \mathrm{~A}$ postura de Barroso de defesa do metalismo não dava muita esperança aos comerciantes que não esperavam que seus interesses junto aos bancos fossem defendidos por um ministro que era bem visto pelos banqueiros internacionais. Não faltaram a Barroso elogios por parte dos Rothschilds quando foram informados das intenções do ministro em efetuar cortes nas mais diversas áreas do orçamento. ${ }^{183}$

O problema naquele momento não era agradar aos banqueiros em Londres, mas atender demandas internas por meio de recursos que não paravam de diminuir em face da guerra e das restrições aos negócios internacionais, situação que encontrava nos discursos de Barroso mais elementos de preocupação com as restrições aos gastos e o aumento da carga tributária que ele defendia como política econômica. Dado o contexto econômico, não tardaria

\footnotetext{
${ }^{181}$ Lei Orçamentária 2.909 de 31 dezembro 1914.

${ }^{182}$ O Estado de S. Paulo, 16 janeiro 1915, p. 4.

${ }^{183}$ O Estado de S. Paulo, 11 janeiro 1915, p. 2.
} 
a primeira troca na Fazenda durante a guerra. Aproveitando-se de afastamento médico do ministro, Wenceslau Braz efetivou Calógeras que estava ocupando a pasta interinamente. ${ }^{184}$

Dos ministros da Fazenda durante a guerra, o nome mais lembrado tem sido o de Pandiá Calógeras, não só porque ele permaneceu mais da metade do governo Wenceslau Braz à frente do ministério, mas também por ele ter ocupado o Ministério da Guerra durante o governo Epitácio Pessoa, e ainda porque sua produção sobre finanças públicas e formação histórica do Brasil se tornaram obras referencias. É de Calógeras documento intitulado "Problemas de Administração", compêndio preparado para o governo de Rodrigues Alves que sucederia o de Wenceslau Braz. Trata-se de um extenso relato sobre a situação orçamentária e administrativa do Brasil em 1918. Nesta obra, Calógeras aborda em detalhes a condição orçamentária de cada ministério para o ano em questão e ainda faz diversas considerações sobre perspectivas para o cenário internacional. Com o fim da guerra, o momento era de esperança, mas Calógeras acreditava que a situação militar do Brasil deveria ser revista para o que o país se encaixasse na nova ordem mundial.

Profundo conhecedor da engrenagem do orçamento fiscal brasileiro, Calógeras escreveu sobre a arte orçamentária e sobre os pecados que sempre acometiam a administração pública nacional, como a falta de critério para a utilização de recursos públicos e o menosprezo por detalhes orçamentários, elementos que tinham o poder atávico de acarretar déficits. Como o período de Calógeras à frente do ministério foi onipresente no governo Wenceslau Braz, não é de se admirar a defesa que o ex-ministro fez da gestão financeira deste governo, quando diversas conquistas importantes teriam sido alcançadas, entre os quais "as despesas públicas foram fortemente diminuídas" e "a normalidade dos pagamentos fora restabelecida no exterior". ${ }^{185}$ Com relação às despesas públicas, Steven Topik corrobora que Wenceslau Braz tenha despendido menos que no período anterior à guerra, apesar de "os problemas financeiros do Tesouro e a nova escola de pensamento econômico" terem levado o governo a aumentar participação no sistema financeiro. ${ }^{186}$ Quanto à volta das remessas dos serviços da dívida externa, Paulo Neuhaus afirma que o governo "fez questão de reiniciar os pagamentos do serviço da dívida em 1917”, mas o próprio autor pondera que o acordo com os

\footnotetext{
184 “O Sr. Barroso vae convalescer em Vassouras”, O Estado de S. Paulo, 03 maio 1915, p. 1.

${ }^{185}$ Calógeras, Formação histórica do Brasil, p.374-5.

${ }^{186}$ Topik, A presença do Estado na economia política do Brasil de 1889 a 1930, p. 57.
} 
credores que resultou no funding de 1914 já havia estabelecido período de três anos como prazo para que o país reorganizasse as suas contas externas. ${ }^{187}$

Independentemente de quem esteve à frente do Ministério da Fazenda durante a guerra, dois temas foram centrais e comuns: a busca pela substituição das receitas que deixaram de ser arrecadadas com o imposto de importação; e o abandono da ortodoxia monetária. ${ }^{188}$ Sobre este tema, a questão-chave era a emissão de moeda em curso forçado, isto é, a emissão do mil-réis sem lastro em ouro, equivalente a dizer que não havia reservas equivalentes em libra esterlina. Por mais que o governo afirmasse que não estava adotando mudança expressiva na condução da economia, não era isto o que a emissão de milhões de contos de réis sem conversão demonstrava, situação que pressionava ainda mais o preço da libra. Na avaliação contida no relatório do Ministério da Fazenda de 1917, a principal causa para a desvalorização do mil-réis deveria ser buscada no setor externo da economia, porque a evolução da guerra e a complexidade da beligerância faziam a demanda por ouro e moedas conversíveis subir a níveis que não eram controláveis, sendo a depreciação da moeda nacional algo inexorável. ${ }^{189}$

Realmente era de se esperar que tivesse havido forte desvalorização do mil-réis, o que colocaria o governo em situação defensiva e muito vulnerável durante todo o período da guerra. Apesar de muita instabilidade cambial e do receio dos empresários ligados ao comércio e à indústria que dependiam de produtos importados, o que se verificou foi uma surpreendente estabilização cambial para um período tão conturbado. O valor da libra manteve média relativamente firme durante a guerra, não se valorizando além dos 11,50 dinheiros/mil-réis e atingindo desvalorização máxima de 16,90 dinheiros/mil-réis entre 1914 e 1918. O intervalo de variação de aproximadamente $50 \%$ não pode ser considerado elevado para um período de mudanças radicais no centro da economia internacional, ainda mais quando se sabe que a cotação da libra no Brasil acabou fechando o ano de 1918 em 13,70/milréis. ${ }^{190}$ Esta aparente contradição cambial é explicada por Winston Fritsch como resultado do funding loan de 1914, contrato internacional no qual foram negociados 15 milhões de libras esterlinas e também por outros acordos celebrados entre entidades públicas brasileiras e

\footnotetext{
${ }^{187}$ NEUHAUS, História Monetária do Brasil, 1900-45, p. 51.

${ }^{188}$ Decreto n$^{\circ} 11.511$, de 04 de março de 1915 e Relatório do Ministério dos Negócios da Fazenda - 1919, p.4.

${ }^{189}$ Relatório do Ministério dos Negócios da Fazenda - 1917, p.196.

${ }^{190}$ IBGE, Tabela II - Curso do câmbio na Praça do Rio de Janeiro - 1822/1939, p. 63.
} 
credores internacionais. ${ }^{191} \mathrm{O}$ valor do funding de 15 milhões de libras representou $130 \%$ do saldo da balança comercial de 1914, proporção que fornece a dimensão da importância do acordo para as finanças públicas brasileiras durante a guerra. ${ }^{192}$

É bem verdade que as dificuldades do governo em equilibrar o orçamento tiveram parcela herdada de administrações anteriores, mas a gestão Wenceslau Braz contribuiu e muito para piorar as coisas ao utilizar ad nauseam a emissão de papel-moeda. Nos dizeres do $O$ Estado de S. Paulo "o atual governo nasceu emitindo, viveu emitindo e estrebucha ainda pedindo emissões e mais emissões". ${ }^{193}$ Manifestações como esta foram comuns no período e é nítida a crítica de parte da imprensa e da comunidade dos negócios em relação a esta mudança na condução da política monetária. $O$ que se entendia no período como uma boa administração monetária tinha como referência a gestão de Joaquim Murtinho na Fazenda, quando políticas ortodoxas recuperaram o poder de compra do mil-réis no início do século $\mathrm{XX}$.

A emissão sem lastro foi defendida por grupos interessados neste tipo de política monetária expansionista, especialmente os cafeicultores e setores do comércio que reclamavam da falta de moeda para as transações comerciais. O debate sobre austeridade monetária ou curso forçado já era considerado antigo, mas as mudanças macroeconômicas trazidas pela guerra obrigaram o governo a modificar a política monetária incorporando as emissões sem lastro. O governo passou o período da guerra procurando sempre contemplar tanto o grupo dos deflacionistas, partidários da moeda valorizada a 27 dinheiros/mil-réis, quanto o grupo dos expansionistas, defensor do mil-réis a 15 dinheiros.

\section{2 - A gestão de Calógeras na Fazenda}

João Pandiá Calógeras nasceu no Rio de Janeiro, mas desenvolveu carreira política em Minas Gerais, compondo os quadros do Partido Republicano Mineiro (PRM). A formação em engenharia com especialização em mineração, a longa temporada de estudos na Europa e as pesquisas de campo foram subsídios para que Calógeras escrevesse "As minas do Brasil e sua

\footnotetext{
${ }^{191}$ Fritsch, “Aspectos da política econômica no Brasil, 1906-1914”, Economia brasileira: uma visão histórica, p. 41.

${ }^{192}$ Abreu, A Ordem do Progresso: Cem Anos de Política Econômica Republicana 1889-1989, p. 445.

${ }^{193}$ O Estado de S. Paulo, 25 setembro1918, p.3.
} 
legislação", obra que se transformou em marco para o setor de mineração e que colocou Calógeras como figura de projeção nacional, basicamente por que ele inovou ao defender a tese de alienação do solo pelo Estado, onde "a União dê as regras para a sua alienação" e "a mineração de jazidas, porventura existentes nelas [terras], só pode ser regulada por lei federal". A repercussão desta obra motivou a formação de um grupo de estudos que resultou na Lei Calógeras, marco regulatório do setor. ${ }^{194}$

A vitória do mineiro Wenceslau Braz na disputa presidencial de 1914 atendeu demanda do PRM e Calógeras foi nomeado ministro da Agricultura, Indústria e Comércio, posto ocupado até julho de 1915, mas já a partir de maio ele passou a acumular funções com a interinidade na Fazenda. Calógeras cumpriu mandato de dois anos e quatro meses no total, período relativamente longo para os padrões da época. O ministro marcou o país, tanto pelo estilo de confronto característico de Pandiá, como porque foi neste intervalo que os efeitos da guerra se fizeram sentir com mais intensidade na economia brasileira, principalmente por que a arrecadação da renda aduaneira foi reduzida a um terço, reflexo da forte queda nas importações do país e, consequentemente, na atividade econômica como um todo. ${ }^{195}$

Calógeras considerava que a partir de 1915 os déficits orçamentários não poderiam ser mais considerados fruto da inépcia na gestão das finanças públicas, mas sim derivados das condições "anormalíssimas decorrentes da grande guerra". A Associação Comercial avaliou a crise em seus diversos aspectos e divulgou documento no qual concluiu que "a grande crise que mais uma vez nos fere é, antes de tudo, uma crise economica, crise de falta de producção exportada. Sua solução, portanto reside na expansão do trabalho agricola."196 Já para Calógeras, a crise tinha total relação com a guerra que aniquilara o recolhimento dos direitos de importação, fato a que se somaram as despesas extraordinárias que a neutralidade impingia às finanças do país por meio dos gastos com navios de patrulhamento do litoral brasileiro. Para tentar reverter este quadro que já seria ruim sem a guerra, a aposta do ministro dependeu em alto grau do aumento da tributação sobre o consumo de cerveja e bebidas alcóolicas em geral, chapéus, fumo, calcados, alimentos em conserva. Foram estipulados, ainda, a criação de adicional sobre as taxas de esgoto no Rio de Janeiro. ${ }^{197}$ A esperança maior para aliviar um

\footnotetext{
${ }^{194}$ Calógeras, As minas do Brasil e sua legislação, p. 479-83.

Decreto $\mathrm{n}^{\circ} 2.933$ (Lei Calógeras), de 6 janeiro de 1915 que regula a propriedade das minas.

${ }^{195}$ Ministério da Fazenda (site) - Galeria de Ministros: João Pandiá Calógeras.

FGV-CPDOC (site) Biografia - João Pandiá Calógeras

${ }^{196}$ O Estado de S. Paulo, 18 julho 1915, p. 1.

${ }^{197}$ O Estado de S. Paulo, 16 setembro 1916, p. 2.
} 
pouco a falta de recursos conversíveis foi depositada mesmo na elevação para $65 \%$ da quotaouro na cobrança do imposto de importação. ${ }^{198}$

A falta de recursos para cobrir o déficit público fez com que o governo dependesse excessivamente do Congresso, mesmo para questões que pareciam menores, como o pagamento de 200 contos de réis a novos funcionários que tinham direito à aposentadoria, mas que obrigou Calógeras a submeter decreto de crédito suplementar. ${ }^{199}$ Nesta relação com o legislativo, quando o assunto era a criação de tributos o governo podia contar com o apoio irrestrito do senador Leopoldo de Bulhões, como no evento que modificou a tributação sobre o açúcar, a gasolina, os depósitos bancários e as apólices. Eram tentativas de reduzir a proporção dos problemas de financiamento interno, mas que acarretavam muita insatisfação no mercado. Criticava-se especialmente Bulhões porque o financista alardeava que estava sempre querendo o melhor na relação o Estado e o setor privado e que suas ideias eram baseadas em exemplos elogiados em outros países, como na Argentina, que aparentava estar administrando a crise melhor que o Brasil. Os críticos diziam que as comissões de finanças comandadas por ele eram carentes de estudos mais sólidos e que buscar recursos desta forma, isto é, aumentando a carga tributária, não era tarefa que exigia conhecimento profundo sobre nada. $^{200}$

A política econômica alicerçada na cobrança de tributos em ouro seria o grande mote para as muitas críticas que foram minando a sustentação de Calógeras na Fazenda. Aumentar a tributação em época de exceção era algo justificável, mas ampliar a exigência para a cobrança em moeda-ouro, com o comércio prejudicado com o cenário de guerra, provocou forte mobilização do setor importador que, com apoio da imprensa, passou a perseguir o objetivo de forçar a revisão da decisão desta medida ou a renúncia de Calógeras. Nem bem assumira, dada a gravidade da crise econômica, a Câmara dos Deputados já passara a especular a renúncia de Pandiá Calógeras que seria substituído por Amaro Cavalcanti, mais identificado com os problemas da época. ${ }^{201}$ Esta mudança realmente viria a ocorrer, mas apenas com o fim do governo Wenceslau Braz, quando o político potiguar assumiu o Ministério da Fazenda. ${ }^{202}$

\footnotetext{
${ }^{198}$ Relatório do Ministério dos Negócios da Fazenda - 1917, p. III.

${ }^{199}$ O Estado de S. Paulo, 5 outubro 1916, p. 4.

${ }^{200}$ O Estado de S. Paulo, 26 novembro 1916, p. 1.

${ }^{201}$ O Estado de S. Paulo, 17 agosto 1915, p. 1.

202 Ministério da Fazenda (site) - Galeria de Ministros - República.
} 
Os efeitos da sonegação e da evasão fiscais durante a guerra foram previstos por Calógeras, que estava ciente da urgência em obter recursos que pudessem cobrir as despesas mais essenciais, daí as mudanças na tributação. A questão é que o ministro também acabou sendo forçado a ir contra a imagem que ele mesmo criara de defensor do mil-réis forte, imagem tão arraigada que se especulou que as emissões de curso forçado teriam sido retomadas por ingerência direta de Wenceslau Braz. Calógeras disse que tentou a todo custo evitar a emissão de curso forçado, mas os títulos públicos que dariam cobertura ao orçamento estavam com cotação em queda por causa da crise advinda com a guerra. Além disto, muitos dos graves problemas de 1917 tiveram origem nos déficits orçamentários do triênio anterior e bastaria como solução a elevação da tributação, mas, em países com economia frágil como o Brasil não se podia esperar retorno imediato de mudanças tributárias, ponderou o ministro, e o curso forçado teve que ser utilizado. ${ }^{203}$

Este retrocesso na condução da macroeconomia brasileira com a volta do descontrole monetário não foi reinaugurado por Calógeras. O demérito coube à gestão de Rivadávia Correia, ministro da Fazenda do final do governo Hermes da Fonseca, quando ficou patente que o ouro que se negociava com os banqueiros em Londres não seria liberado no primeiro semestre de 1914. O problema é que as emissões realizadas sem lastro sob o comando de Calógeras alcançaram valor muito superior ao total de 250 contos emitido em 1914. ${ }^{204}$ Preocupado em justificar esta política econômica com montantes sem lastro tão elevados e tão criticada por agentes econômicos no Brasil e no exterior, o ministro achou por bem divulgar o destino destes recursos entre 1914 e 1917, informação sumarizada na Figura 5.1.

Figura 5.1 - Destino das emissões de curso forçado realizadas entre 1914 e 1917 (contos de réis)

\begin{tabular}{lr}
\hline & Contos de réis \\
\hline Empréstimos ao Banco do Brasil & 90.000 \\
Empréstimos a indústrias (via Banco do Brasil) & 11.000 \\
Empréstimo para a compra de café & 110.000 \\
Empréstimo a empresas de carvão & 3.800 \\
Notas da Caixa de Conversão ao câmbio de 16 d. & \\
(sem ágio de 30\% praticado pelo mercado) & 73.791 \\
Ouro adquirido a média de 12,5 d. & 10.595 \\
Compra de borracha & 17.000 \\
Total & 316.186 \\
\hline
\end{tabular}

Fonte: Relatório do Ministério dos Negócios da Fazenda 1917, p. 8.

\footnotetext{
203 O Estado de S. Paulo, 18 julho 1915, p. 1.

${ }^{204}$ Relatório do Ministério dos Negócios da Fazenda - 1917, p. IV.
} 
O total emitido sem lastro no mesmo período foi de 750.000 contos, indicando que aproximadamente 434.000 contos foram destinados a cobrir os déficits orçamentários, valor ao qual se deve somar a emissão de letras nos totais de 21.408 contos em ouro e de 170.538 contos em papel, para finalidades descritas na Figura 5.2. Para dimensionar e contextualizar estes valores, Calógeras se preocupou em informar que a legislação ainda lhe facultava a emissão suplementar de 141.226 contos. Esta conta levou em consideração a autorização fixada em lei que permitia emissão de até cinco vezes a base em ouro. Considerando o espólio da Caixa de Conversão, os recursos em guarda do Banco do Brasil, os valores depositados no Tesouro, e ouro em barra, chega-se ao total de 48.245 contos. $^{205}$

Figura 5.2 - Finalidade de títulos públicos emitidos entre janeiro de 1915 a março de 1917 (contos de réis) Contos de réis

Contratos relativos à construção e aquisição de estradas de ferro 59.950

Pagamento de compromissos do Tesouro e resgate de letras

Saneamento da baixada fluminense

Pagamento de sentenças judiciárias

Pagamento de despesas vencidas da empresa Lloyds de Navegação

Indenização à Bolívia

Encampação da Estrada de Ferro Noroeste do Brasil

Total

Fonte: Relatório do Ministério dos Negócios da Fazenda 1917, p.

10.

Nota-se que as grandes necessidades financeiras eram com o próprio Tesouro e com um elemento que marcou a Primeira Guerra Mundial no Brasil, a questão das estradas de ferro. A expansão dos serviços ferroviários e a federalização das operações significaram grandes desencaixes de recursos que exigiram muita criatividade financeira da Fazenda.

A conta das obrigações do Tesouro, apesar de elevada, ainda não estava fechada. Além dos títulos do Figura 5.2 ainda foram emitidas letras com base no funding, sendo 37.371 contos de réis em 1915, 33.472 em 1916 e 28.229 em 1917. No segundo semestre de 1917, de acordo com estabelecido no contrato de 1914, cessaram as emissões de títulos lastreados e foi retomado o pagamento do serviço da dívida externa. Este foi um momento de grande tensão no governo e no mercado por conta da notória incapacidade do governo de administrar as

\footnotetext{
${ }^{205}$ Relatório do Ministério dos Negócios da Fazenda - 1917, p. 9.
} 
despesas ordinárias que ainda teriam dificuldade suplementar em arcar com estes desembolsos previstos no acordo da dívida externa, mas para os quais não houvera empenho fiduciário. ${ }^{206}$

As críticas à politica de Calógeras pareciam unânimes, mas a Associação Comercial do Rio de Janeiro arrumou espaço para considerações ao admitir que na Europa estava sendo visto como natural o fato de que os países fossem obrigados a aumentar a carga tributária e a imprimir moeda. Os empresários brasileiros não deixaram de registrar, porém, que havia diferenças nos motivos que norteavam as emissões sem lastro. Se entre os europeus isto ocorria para fazer face aos dispêndios com a guerra que não puderam ser previstos, no Brasil a prática tinha como objetivo cobrir o déficit orçamentário, situação que ocorreria mesmo antes de 1914. Se as despesas brasileiras eram previstas, o que o governo deveria fazer, dizia a Associação, era buscar o financiamento por meio da elevação das receitas, desde que isto não significasse majoração da carga tributária. ${ }^{207}$

A emissão de papel que já saía desvalorizado só piorava as condições do mercado por que o câmbio a libra com preço elevado atingia diretamente a oferta de produtos por que a maioria dos artigos tinha origem nas importações que ficavam mais caras com a desvalorização do mil-réis. A valorização da libra foi impulsionada com o aumento do meio circulante que passou de 600 contos de réis ao final de julho de 1914 - início da guerra - para algo como 750 contos em novembro de 1917. Apesar de este não ter sido o único fator que provocou redução na taxa cambial, foi com certeza o mais criticado pelo mercado que não poupou espaço na imprensa para expor os problemas que a instabilidade cambial provocava no ambiente dos negócios, essencialmente limitando investimentos e reduzindo a margem de lucro. $^{208}$

Na avaliação dos críticos do governo, a emissão de papel moeda parecia ser o único instrumento da política econômica para tentar o equilíbrio orçamentário. O déficit global dos três anos da guerra foi de 688.100 contos e foi atendido com emissões de 553.000 contos, mas ainda restaram 135.100 contos que tiveram que ser cobertos com a emissão de títulos. Este acúmulo de pontos negativos - emissão sem lastro e aumento da dívida pública - teve grande repercussão no mercado e colaborou para ampliar o pessimismo que já havia se instalado com a guerra e seus prováveis desdobramentos.

\footnotetext{
${ }^{206}$ Relatório do Ministério dos Negócios da Fazenda 1917, p. 11.

${ }^{207}$ O anno commercial e financeiro de 1917, p. 3-6.

208 Ibidem.
} 
Se o conflito na Europa trouxe oportunidades de negócios, estas não foram suficientes para combater os problemas que a política econômica passou a gerar com a combinação da elevação de tributos sobre o consumo e importações, as emissões de curso forçado e o avanço da dívida pública. A Fazenda não poderia continuar com a prática de emitir papel novo para completar a receita por que a sobrecarga na dívida pública estava se tornando perigosa demais. ${ }^{209}$ Em estudo realizado sobre tributação pela Associação Comercial para o orçamento de 1917, concluiu-se que os tributos federais somaram 63,32\% da receita pública, enquanto que rendas diversas representaram 19,81\% e títulos do funding mais depósitos em Londres com 16,87\%. Dos tributos, 88,79\% foram indiretos e 11,21\% diretos. Direitos de importação foram de $53,90 \%$, impostos de consumo $26,01 \%$, o imposto do selo $7,25 \%$ e outros tributos em $4,98 \%$.

As muitas críticas feitas pelo comércio versavam, basicamente, sobre a incapacidade do governo em seguir modelos exitosos de tributação considerada moderna, como o que vinha sendo executado pelos Estados Unidos e que estava permitindo a substituição da dependência de tributos considerados improdutivos pelo imposto de renda. O ponto central da desaprovação dos empresários era o imposto de importação, que nos Estados Unidos, diziam, era utilizado sem relação alguma com o orçamento por que as rendas aduaneiras seguiam os cânones da tributação e não havia a vinculação destas receitas com as despesas, como ocorria no Brasil. Eram, portanto, sistemas tributários que partiam de premissas absolutamente diferentes. $^{210}$

Calógeras não era indiferente à insatisfação do mercado. $\mathrm{O}$ ministro entendeu por bem dar resposta na forma de um estudo amplo e bastante técnico que visava reduzir a dependência do setor público do imposto de importação e cobrir parte do déficit estimado para 1917. A figura 5.3 contém a sinopse deste estudo.

Figura 5.3 - Proposta do Ministério da Fazenda para cobrir o déficit de 1917.

\begin{tabular}{lccc}
\hline & \multicolumn{3}{c}{ Ação } \\
\hline Base & Revisão & Criação & Utilização \\
\hline Imposto de indústrias e profissões & $\mathrm{X}$ & $\mathrm{X}$ & \\
$\begin{array}{l}\text { Imposto sobre o consumo de açúcar } \\
\text { Imposto do selo }\end{array}$ & $\mathrm{X}$ & &
\end{tabular}

${ }^{209}$ O anno commercial e financeiro de 1917, p.7 e 8.

${ }^{210}$ O anno commercial e financeiro de 1917, p. I-9. 
Imposto sobre rendimentos

Depósitos em Londres

Imposto sobre o consumo de manteiga $\mathrm{X}$

Imposto sobre o consumo de tecidos $\mathrm{X}$

Fonte: $O$ anno commercial e financeiro de 1917, p. I-4.

A base de Calógeras para o estudo sobre tributação foi o modelo francês de classificação do imposto sobre rendimentos que previa as seguintes diferenciações ${ }^{211}$ :

-Renda de propriedade imóvel construída

-Renda de propriedade imóvel não construída

-Renda dos valores e capitais móveis

-Lucro da exploração agrícola

-Lucro do comércio, da indústria, da exploração de minas, dos cargos e dos ofícios

-Rendimento das profissões liberais

-Rendimento dos empregos públicos e dos privados

-Renda de todos os capitais e de todas as ocupações lucrativas não especificadas

-Aposentadorias, reformas, pensões e rendas vitalícias

Tentativas como esta de demonstrar engajamento com mudanças na política econômica não facilitaram a situação entre Calógeras e o Congresso, como o prova o fato de o projeto orçamentário de 1917 que Calógeras enviou à Câmara teve os seus números refeitos pelo Legislativo que conseguiu chegar ao equilíbrio orçamentário. O problema, como registrou o senador Leopoldo de Bulhões, é que tudo foi feito eliminando despesas de maneira aleatória, além do que títulos de receitas foram inflados, deixando o déficit latente, em clara manobra dos legisladores em camuflá-lo. Este era um dos graves problemas na relação entre o executivo e os congressistas, a falta de sintonia que denotava em muitas ocasiões crises de governabilidade.

O saldo orçamentário previsto pela Câmara para 1917 era, na opinião de Bulhões, ratificada pela Associação Comercial, "simples miragem resultante de um factor negativo como é, sem a menor dúvida, o ágio do ouro, ou, em outras palavras, a depreciação do numerário circulante. ${ }^{, 212}$ Estudando a composição do orçamento, Bulhões chegou à conclusão

\footnotetext{
${ }^{211}$ O anno commercial e financeiro de 1917, p. I-4.

${ }^{212}$ O anno commercial e financeiro de 1917, p. I - 6 .
} 
que o déficit de 1917 poderia ser estimado em 1.453.801 contos de réis, valor por demais elevado, raiz dos problemas que comprometiam o desempenho da economia nacional. Os entraves econômicos durante a guerra eram tantos que Bulhões teceu críticas ao Ministério da Fazenda, listando os pontos que deveriam ser melhorados e caminhos a ser trilhados, conforme relatado a seguir. As críticas são transcrições do original, e as soluções propostas versões do texto apresentado no compêndio elaborado por Ramalho Ortigão, membro do Instituto Histórico do Rio de Janeiro e presidente da Liga do Comércio. ${ }^{213}$

1 - "É preciso economisar"

Solução: obras por contratos ou por administração deveriam ser suspensas. Novas despesas somente se relacionadas à segurança nacional, à segurança pública ou ao abastecimento de gêneros alimentícios para consumo interno e externo.

2 - "É preciso trabalhar e produzir"

Solução: incrementar a produção, reduzir fretes no transporte de alimentos, construir estradas de rodagem e organizar o crédito agrícola.

3 - "É preciso e inadiavel reformar o nosso systema tributario"

Solução: eliminar dependência que os serviços federais e o crédito da União tinham da renda aduaneira. Eliminar dependência que as receitas estaduais tinham da renda de exportação;

4 - "É preciso fazer bôa e sã politica monetaria"

Solução: diminuir a circulação fiduciária como medida de prevenção ao retorno da normalidade nas relações com o setor externo da economia, especialmente o comércio exterior que a guerra alterou gravemente. Para tanto, deveriam ter fim as emissões sem lastro realizadas pelos bancos, deixando espaço para que apenas o Tesouro utilizasse o recurso como forma de, na falta de outros meios, atender as necessidades públicas. Além disto, o fundo de garantia, utilizado para a estruturação da Caixa de Conversão, deveria ser restaurado.

5 - "É preciso, entretanto, e indispensavel haver sequencia na politica financeira"

Solução: restaurar o crédito e regularizar as finanças públicas.

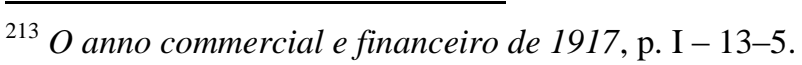


Bulhões identificou em suas críticas a dificuldade de ações concretas por que as influências da moratória externa, o funding loan, e as emissões de curso forçado condenavam o país a ver aumentada de maneira contínua a dívida consolidada e a dívida flutuante que eram empregadas como mecanismo para financiar as despesas orçamentárias. Apesar da abordagem generalista, o cerne dos problemas econômicos do país foi atacado pelo senador: a dependência dos tributos aduaneiros e o poder de contágio das modificações do setor importador nos negócios no Brasil. ${ }^{214}$ As soluções, porém, muito dificilmente poderiam ser incorporadas à política econômica porque feriam principais constitucionais, caso das rendas estaduais, porque a sua aplicação envolveria recursos externos que não estavam disponíveis à época. Este era o caso do restabelecimento do fundo de garantia que estruturou a Caixa de Conversão em 1906 ou mesmo porque durante a guerra vigorou a regra de exceções para o comércio exterior, caso da Statutory List, tema da seção 10.1 que analisa os impactos desta medida na economia brasileira.

A aguda situação vivida pelo país levou a Associação Comercial a montar uma representação junto ao Congresso com vistas a elaborar com o governo um plano que viabilizasse o funcionamento da economia nacional atacando o déficit público, buscando a estabilização do câmbio a $12 \mathrm{~d}$. e obtendo o aumento da base monetária. $\mathrm{O}$ foco era solucionar as grandes questões econômicas de tal forma que houvesse uma regeneração do país, mesmo no contexto das severas restrições impostas pela IGM. Um exemplo das medidas que a Associação Comercial defendeu foi o Banco do Brasil passar a acumular a função de emissor de moeda. ${ }^{215}$ Esta possibilidade foi analisada no Capítulo 6 - Atuação do Banco do Brasil no setor externo da economia brasileira.

A necessidade de recursos em ouro para honrar compromissos externos, especialmente após o retorno do pagamento do serviço da dívida externa em 1917, era motivo de grande preocupação porque os negócios estavam parados. Não havia perspectiva de fim da crise no curto prazo, mas a Associação Comercial queria encontrar uma maneira de fazer a economia brasileira voltar a funcionar mesmo naquela conjuntura de estrangulamento externo. Era necessário encontrar uma saída que prescindisse de aumento da tributação porque isto asfixiaria ainda mais os setores produtivos. Defendendo-se das acusações de querer beneficiar apenas o comércio importador, a Associação Comercial afirmava que o comércio era o motor da indústria, setor que poderia e deveria se expandir para o exterior.

\footnotetext{
${ }^{214}$ O anno commercial e financeiro de 1917, p. I - 12 e 13.

${ }^{215}$ Retrospecto Commercial 1916, p. 37.
} 
A cobrança de tributos aduaneiros tinha que ser modificada por que ultrapassava em muitos casos o valor do bem importado. Esta situação tendia a piorar ainda mais com o aumento da cobrança da quota-ouro, visto que algumas empresas teriam que contrair dívidas para poder arcar com a diferença do valor que passaria a ser pago às coletorias. Havia também o problema da taxa cambial. O governo fixou o câmbio para impostos em 27 d., mas o mercado chegou a pagar $12 \mathrm{~d}$. em alguns momentos. Esta diferença, e especialmente a oscilação cambial, era motivo de pressão do comércio sobre o governo. Exigia-se a estabilização do câmbio, de preferência em 12 d. ${ }^{216}$ As perguntas dos empresários resumiam bem a situação da economia nacional. Os questionamentos passavam pelo grande desejo da época que era a estabilidade cambial. Se a estabilidade macroeconômica não fosse alcançada, pensar em ampliar o sistema financeiro, em aumentar o parque industrial ou em mesmo modernizar a tributação seriam esforços esvaziados. ${ }^{217}$

A carga tributária obrigava a sociedade a pagar 925 mil contos ao Estado, montante considerado ultrajante pelo setor produtivo porque representava $43 \%$ da produção anual, verdadeiro confisco, na opinião da classe empresarial. Com Calógeras falando em aumentar a tributação, a situação ganhava ares de revolta aberta porque muito da reclamação dos empresários vinha do aumento do imposto de importação. Nas manifestações dos empresários do comércio fica patente o ponto central que os opunha à política econômica do governo era a tributação sobre as importações, objeção que foi inflada quando a quota-ouro passou de $40 \%$ para $65 \%$. Procurando os motivos para medida "tão descabida" que muitos comerciantes viam como inviabilizadora das atividades do setor, a Associação Comercial identificou no setor industrial o maior beneficiário desta medida drástica. ${ }^{218}$ Com a nova cobrança, a proteção à produção nacional aumentaria naturalmente, mesmo que o objetivo da mudança na alíquota tivesse sido a de financiar o déficit público.

Foi formada uma associação de classe especial para tratar os assuntos durante o auge da crise, a Liga do Commercio, que passou a publicar relatórios afirmando que a péssima gestão econômica e financeira do país era a base dos problemas que os negócios enfrentavam. O governo estava equivocado e deveria facilitar a importação e não criar obstáculos. Os custos para o comércio aumentaram com o encarecimento dos fretes e dos seguros como reflexo da guerra. O governo aprovou aumento na quota-ouro e adicional de $10 \%$ sobre os

\footnotetext{
${ }^{216}$ Retrospecto Commercial 1916, p. 38.

${ }^{217}$ Retrospecto Commercial 1916, p. 39.

${ }^{218}$ Retrospecto Commercial 1916, p. 47.
} 
fretes internacionais. Se a tudo isto fosse incluída a questão do câmbio, os preços finais dos produtos aos consumidores teriam que ser forçosamente majorados. A libra esterlina que valia $15 \$$ passara a $20 \$$. A base da administração pública estava realmente em todo equivocada, pois, se o objetivo era aumentar a arrecadação, compensando as perdas provocadas pela guerra, os direitos aduaneiros deveriam ser reduzidos. Isto era exatamente o caminho contrário que as ações da Fazenda indicavam. ${ }^{219}$

A estabilidade cambial somente seria obtida com o desenvolvimento sustentável da economia e não com artifícios como os que já vinham de muito sendo adotados e que agora eram chancelados por Pandiá Calógeras. O exemplo dado pela Liga do Comércio era o de um comerciante que trabalhasse com um capital relativamente elevado. Se a taxa cambial passa de 16 d. para 12 d., o capital necessário à continuidade do negócio aumentaria de maneira expressiva, forçando-o a contrair dívidas com juros elevados ou a fechar as portas. O setor comercial acreditava que se a ideia era incentivar a indústria, o que se deveria fazer era não criar empreendimentos que dependessem do governo porque quanto maior a proteção, maior a possibilidade de abandono dos consumidores e da entrada de concorrentes. A Fazenda deveria repensar a solução dos problemas econômicos e conduzir estudos alicerçados nas taxas de consumo, no imposto de renda, no combate ao contrabando e na redução dos gastos públicos. $^{220}$

O fato de ter sido ministro da Agricultura facilitou o trânsito de Calógeras junto ao setor primário da economia brasileira. Durante a feira "Exposição do Milho" realizada em São Paulo em julho de 1915, Calógeras foi congratulado pela realização do evento. Neste momento o ministro aproveitou para solicitar apoio aos agricultores para enfrentar a "situação dificílima que actualmente atravessamos". ${ }^{221}$ Apesar deste clima favorável, havia sempre uma questão que atormentava a relação entre Calógeras e a elite cafeeira que não esquecera quando o mandatário da Fazenda foi contrário ao Convênio de Taubaté, posicionamento que o enfraquecia na relação com os empresários paulistas do setor agrícola, principalmente. ${ }^{222}$

A conturbação que envolvia o mercado foi momentaneamente amenizada quando da sanção do Decreto Financeiro $n^{\circ} 2.986$, que passou a permitir ao governo a realização de operações de crédito para liquidar ou consolidar compromissos, amparar e fomentar a

\footnotetext{
${ }^{219}$ Retrospecto Commercial 1916, p. 49.

${ }^{220}$ Retrospecto Commercial 1916, p. 52.

${ }^{221}$ O Estado de S. Paulo, 24 julho 1915, p. 4.

${ }^{222}$ O Estado de S. Paulo, 20 julho 1917, p.2.
} 
produção nacional, suprir deficiências da receita orçamentária e permitir ao Banco do Brasil realizar operações de desconto, redesconto e caução de apólices, ampliação de agências no território nacional e fomento de exportações de carnes e frutas. Além deste, foi assinado o decreto 11.693 autorizando o ministro da Fazenda a emitir apólices em papel com juro anual de 5\%, a emitir notas do Tesouro Nacional até a quantia de 150.000:000\$000, e igual quantia em apólices de 1:000\$000 em papel, com juro de 5\% papel, como garantia especial para o resgate da mesma emissão. ${ }^{223}$

A imprensa registrou atitudes que demonstraram o perfil centralizador de Calógeras em ingerências que ele praticou no Banco do Brasil, como na ocasião quando ele atendeu solicitação do deputado Felix de Miranda do Rio de Janeiro para que fossem facilitadas as operações de crédito para a indústria do açúcar, tema de interesse absoluto do parlamentar que possuía investimentos no setor. ${ }^{224} \mathrm{O}$ problema foi que na mesma época Calógeras gerou muita polêmica antes de liberar recursos para obras emergenciais que tinham impacto direto na sociedade, como o problema da seca. O ministro era acusado de não ponderar quanto à tipificação dos gastos, fazendo uma política equivocada de contenção de despesas ao colocar no mesmo grau de importância dispêndios para atender políticos que legislavam em causa própria e verbas para o combate à sede na Bahia, em Sergipe e no Ceará, estados que estavam passando por um período de estiagem histórica. A justificativa de Calógeras para se defender da acusação de estar dificultando a liberação dos recursos era a falta de técnicos no Ministério para a análise das solicitações. ${ }^{225}$

Apesar do clima de beligerância com a imprensa e com parte do empresariado, houve alguns momentos de sintonia entre a Fazenda e o mercado, como quando a preocupação com a diversificação do mercado para o comércio brasileiro ganhou impulso com os embargos provocados pela guerra e fez surgir uma comissão formada por empresários que estruturou plano para divulgar produtos brasileiros nos Estados Unidos e que acabou por contar com o apoio de Calógeras, dando à empreitada o caráter oficial que os empresários tanto requeriam. ${ }^{226} \mathrm{O}$ ministro da Fazenda foi além e decidiu criar uma embaixada para cuidar especificamente da propaganda do Brasil no exterior, mas não seria uma embaixada no

\footnotetext{
${ }^{223}$ O Estado de S. Paulo, 30 agosto 1915, p. 3 e 4.

${ }^{224}$ O Estado de S. Paulo, 24 outubro 1915, p. 2.

${ }^{225}$ Para exemplo investimentos públicos em obras de combate à seca durante a Primeira Guerra Mundial, ver : Monte, O uso e controle das águas no processo de modernização do Estado do Ceará: o caso da Barragem do Castanhão, p. 152-5. 
conceito formal do termo e sim um anexo ao gabinete dele no Rio de Janeiro que funcionaria como um comitê permanente. ${ }^{227}$ Este momento teve características de choque adverso no sentido dado pela historiografia que credita à Primeira Guerra Mundial o papel de indutor da industrialização brasileira antes de 1930. Este lado empreendedor de Calógeras fez com que ele recebesse empresários em seu gabinete com frequência acima da média dos ministros anteriores. As questões abordadas versavam da falta de matérias-primas importadas à extensa burocracia exigida para atender à determinação de registro nas repartições fiscais das notas fiscais para a cobrança do imposto de consumo. ${ }^{228}$

O ministro da Fazenda tinha preferência por questões que envolviam operações complexas, e ele foi considerado o responsável por tentar entabular algum tipo de negociação acerca do intrincado caso dos navios alemães que estavam ancorados nos portos brasileiros. As possibilidades que Calógeras tentou para dissipar os embaraços que travavam uma solução final contaram com apoio do governo e chegaram a envolver negociações diretas até mesmo com a Alemanha, mas as restrições que o Reino Unido impunha para acordos com os inimigos inviabilizaram a ousadia. Alternativa que se discutiu na Fazenda era seguir o exemplo da Itália e de Portugal e tomar os bens dos países da Tríplice Aliança, deixando o registro que reparações e compensações fiduciárias, se cabíveis, seriam discutidas ao fim da guerra. $^{229}$

Os navios alemães seriam mais do que adequados para o Brasil resolver o problema logístico que a guerra introduzira no comércio exterior, e foi exatamente com base nesta questão de transportes que houve mobilização dos países vizinhos. Foi formada uma comissão de estudos de comércio marítimo durante a realização do Congresso de Financistas em Buenos Aires, em abril de 1916. Neste evento, foi lançada a ideia da estruturação de uma empresa de navegação que atendesse a região, empresa que seria formada por capitais de todo o continente. Calógeras foi destaque nesta discussão ao colocar o Brasil como maior interessado nas operações deste futuro empreendimento em logística porque o país era responsável pela maior fatia do tráfego entre as duas Américas. Os delegados de outras nações, como os do Chile, concordaram com a posição de Calógeras, levando o Congresso a apoiar formalmente a proposta do ministro brasileiro. Havia o receio que a busca por solução que garantisse o mínimo de serviços de transporte marítimo já havia esgotado as alternativas

\footnotetext{
${ }^{227}$ O Estado de S. Paulo, 23 janeiro 1916, p. 2.

${ }^{228}$ O Estado de S. Paulo, 18 janeiro 1916, p. 2.

${ }^{229}$ O Estado de S. Paulo, 03 março 1916, p. 1.
} 
existentes. Os congressistas acreditavam que somente uma nova empresa administrada por agentes privados ou de governos americanos poderia salvar os negócios. ${ }^{230}$

As dificuldades econômicas trazidas pela guerra levaram os congressistas reunidos em Buenos Aires a debater proposta para a criação de uma moeda única para o continente. Esta moeda teria unidade equivalente a 1/5 do dólar, com múltiplos calculados de acordo com o sistema decimal. Os estudos para esta proposta deveriam considerar o envolvimento dos bancos que tivessem operações na maior parte do continente americano. ${ }^{231}$ As discussões não resultaram na criação desta moeda, mas tiveram o mérito de expor que as dificuldades cambiais pelas quais a economia brasileira passava durante a guerra eram similares as dos outros países latinos.

Temas ligados à isenção de tributos e concessões não eram questões que Calógeras parecia se envolver com tenacidade. A linha do ministro combinava mais com a aventada possibilidade da moeda única para os países latinos porque estava no mesmo grau de criatividade que ele exaltava quando se referia ao que estado de São Paulo obtivera com medidas que buscavam reduzir os efeitos negativos da guerra nos negócios locais. Para Calógeras, a forma como São Paulo estava resolvendo os obstáculos à exportação do café era o mais surpreendente porque Altino Arantes, presidente do Estado, não aguardava soluções prontas do governo federal e deliberava a seu modo problemas como o crédito bancário, navegação internacional ou mesmo mão de obra para a lavoura. ${ }^{232}$ A ideia de uma administração eficiente, executada por empreendedores que valorizavam os negócios e o lucro já permeava as discussões sobre a gestão do setor público brasileiro. O que a guerra parece ter feito foi exacerbar a importância de um governo eficiente.

Boatos sobre a saída de Pandiá Calógeras sempre voltavam a alimentar especulações no mercado, causando a impressão que o ministro estava apenas de passagem na Fazenda. ${ }^{233}$ Algumas das especulações sobre a provável exoneração tiveram origem até mesmo em manifestações públicas de Wenceslau Braz, como ocorreu ao final de novembro de 1916 quando o presidente não se preocupou em dissimular que a Fazenda deveria ter mudança de comando. A origem para esta postura de Wenceslau pode ser encontrada nas articulações

\footnotetext{
${ }^{230}$ O Estado de S. Paulo, 12 abril 1916, p. 6.

${ }^{231}$ O Estado de São Paulo, 12 abril 1916, p. 6.

${ }^{232}$ O Estado de S. Paulo, 17 agosto 1916, p. 11.

${ }^{233}$ O Estado de S. Paulo, 05 outubro 1916, p. 4.
} 
políticas que ganhavam força no Palácio do Catete e que passaram a envolver o nome do ministro como elemento fundamental nas negociações da base de apoio do governo. ${ }^{234}$

Não ajudava muito na manutenção de Calógeras na Fazenda o fato de suas relações com o Congresso não terem sido das mais cordiais. Para o Congresso, a divergência entre Pandiá Calógeras e o chanceler Nilo Peçanha sobre a forma de resolver o caso dos navios alemães foi elucidativa porque o ministro não dera sinais de que estava disposto a negociar. ${ }^{235}$ Calógeras insistia que os navios deveriam pagar estadia pela utilização dos portos brasileiros, valor que a Fazenda calculava em cerca de 30 mil contos de réis, montante que ajudaria a financiar os gastos públicos, mas esta posição afetava as negociações que Peçanha entabulava em Paris e em Londres que não concordavam em pressionar o Império Alemão neste ponto. ${ }^{236}$

Calógeras foi atacado na Câmara dos Deputados com base nos mais diversos motivos, como a malversação de recursos no sistema ferroviário - especialmente a Central do Brasil porque os contratos para o fornecimento de carvão foram considerados irregulares. Houve críticas também para a relação do governo com a empresa de navegação Lloyd Brasileiro que estava tendo dificuldades ímpares para operar durante a guerra. ${ }^{237}$ A campanha parlamentar contra Calógeras fez com que os deputados que se revezassem nos ataques, mas o nome de Maurício de Lacerda se sobressaiu. O deputado federal fluminense manteve controle sobre as principais ações do ministro da Fazenda com o intuito de identificar pontos de vulnerabilidade nos contratos firmados pela Fazenda ou mesmo questões que envolvessem a vida privada de Pandiá, como quando foi levantada a hipótese que Pandiá Calógeras seria sócio na mina de carvão do Jacuí e que, por isto, todos os contratos entre o governo e a empresa que administrava a mina deveriam ser revistos. ${ }^{238}$

O mercado dava como certa a exoneração de Pandiá Calógeras no segundo semestre de 1917. Especulava-se que o mais lógico era que a pasta da Fazenda passasse para Antônio Carlos de Andrada porque ele era líder na Câmara e presidente da comissão de finanças. ${ }^{239}$ Foi o que ocorreu a partir 06 de setembro de 1917. O período no qual Antonio Carlos de Andrada ocupou a pasta da Fazenda coincidiu com a fase final da guerra, fase na qual o Brasil

\footnotetext{
${ }^{234}$ O Estado de S. Paulo, 24 novembro 1916, p. 1.

${ }^{235}$ O Estado de S. Paulo, 16 agosto 1917, p. 4.

${ }^{236}$ O Estado de S. Paulo, 18 julho 1917, p. 1.

${ }^{237}$ O Estado de S. Paulo, 19 junho 1917, p. 4.

${ }^{238}$ O Estado de S. Paulo, 20 junho 1917, p.4.

${ }^{239}$ O Estado de S. Paulo, 19 agosto 1917, p. 2
} 
havia rompido relações com o Império Alemão e muitas mudanças se fizeram sentir na economia brasileira.

A pressão para a saída de Calógeras contou também com a participação dos muitos inimigos que o ministro fez no comércio, que não poupava críticas à cobrança da quota-ouro e à contínua elevação da carga tributária que cálculos da diplomacia britânica estimaram em $20 \%{ }^{240}$ Como se não bastasse este clima ruim no mercado, Calógeras piorou de vez a situação ao decidir colocar em prática sua visão sobre qualidade na gestão da administração pública, especialmente quando ele mandou fazer uma grande reforma nos quadros das alfândegas que resultou na demissão de dezenas de servidores. ${ }^{241}$ Este ato foi visto como uma afronta à classe do funcionalismo público que era unida e não tardaria para exigir mudanças na Fazenda.

A renúncia não foi surpresa nem em termos nacionais nem para a diplomacia britânica porque as especulações passaram a ter origem em diversos setores. Na interpretação de Arthur Peel, chefe da Delegação Britânica no Brasil, a perda de confiança no ministro se instalou irremediavelmente quando do retorno da emissão de moeda sem lastro. Todos estes fatos já seriam mais do que suficientes para comprometer a relação entre Calógeras e os formadores de opinião no Brasil, mas a chancelaria britânica inovou ao acreditar que o ponto central para a queda do "todo poderoso político" foi a insistência da Fazenda em passar a controlar as atividades das companhias marítimas que operavam no país, principalmente no que tangia ao consumo de carvão nos navios. Ainda em linha contrária às opiniões que predominavam no Brasil no segundo semestre de 1917, o banco Rothschild emitiu correspondência enaltecendo os feitos de Calógeras nas tentativas de saneamento das finanças nacionais. O combate aos gastos públicos supérfluos e às fraudes entusiasmaram os banqueiros que saudaram como muito positiva justamente uma das medidas que mais causou polêmica em termos internos, como foi o notário caso da alfândega de Pernambuco que resultou na demissão de 200 funcionários públicos após investigações apontarem como criminoso o incêndio que destruiu as provas da prática de concussão. ${ }^{242}$

Apesar destas manifestações de apoio que chegavam do Reino Unido, as relações de Calógeras com os políticos britânicos não foram das mais diplomáticas, com momentos de

\footnotetext{
${ }^{240}$ Para movimentação tributária no Brasil durante a guerra, ver: Neuhaus, História Monetária do Brasil, 190045 , p. 51.

${ }^{241}$ O Estado de S. Paulo, 24 agosto 1917, p. 5.

${ }^{242}$ Dr. João Pandiá Calógeras - Reports resignation from ministry of finance. FO 371/2900/203227, 23 outubro 1917, p. 129-131.
} 
crítica aberta ao desempenho do ministro. O clima ruim entre o governo britânico e Calógeras continuou até mesmo após a exoneração, como ficou registrado à época da visita oficial que uma delegação de negócios do Brasil realizou na Europa no pós-guerra. A repentina decisão tomada por Calógeras, chefe da missão, de deixar Londres e rumar para a França antes do término das negociações, sem comunicar o fato às autoridades britânicas, deixou a chancelaria perplexa. Para além de ânimos feridos, o que preocupava mesmo era a possibilidade de o Brasil se aproximar de Paris neste pós-guerra porque o momento preconizava uma miríade de possibilidades de negócios com altas margens de lucro para os europeus. ${ }^{243}$

Em suas reminiscências, Calógeras registrou que estava convencido que sua gestão na Fazenda tivera o mérito de valorizar o câmbio por meio do cumprimento do acordo da moratória, fato que deveria ser enaltecido porque fora executado em plena guerra. A valorização dos títulos públicos e do câmbio, que teria passado de $11 \mathrm{~d}$. para $14 \mathrm{~d}$. seriam provas de que foi possível "liquidar o passivo das devastações realizadas no período anterior, e cumprir o segundo funding, a que tais loucuras haviam conduzido." Com o fim da guerra, Calógeras avaliou que a situação voltara ao caos e a carestia atingira patamar tão elevado que a fome passou a grassar nos lares da população urbana mais pobre. ${ }^{244}$

A posição de destaque que Calógeras teve na delegação brasileira que elaborou o Tratado de Versalhes é um bom indicativo que o ostracismo estava longe de marcar a vida pública do agora ex-ministro e que a experiência acumulada por ele nesta conturbada fase da economia brasileira durante a guerra foi bastante útil para que ele se transformasse em referência para abordagens sobre finanças e setor público durante a Primeira República.

O período de Calógeras no comando da Fazenda foi marcado por diversos embates com o setor produtivo. Foram momentos nos quais a força da agricultura para o funcionamento da economia brasileira ficou bastante evidente, assim como ficou patente a dificuldade que a indústria teve em ampliar o seu espaço na economia brasileira durante a guerra porque o comércio e a agricultura ganharam ainda mais importância naquela fase de restrições orçamentárias e de escasso crédito internacional. Neste contexto, foram sintomáticas as solicitações da Associação Comercial para que o governo preservasse a

\footnotetext{
${ }^{243}$ Army Council request confirmation of statement that Dr. Calogeras has left and is not expected to return, 12 agosto 1919, FO 371/3654/115168, p. 403-6.

${ }^{244}$ Calógeras, Estudos históricos e políticos, p. 556.
} 
qualidade da circulação metálica por meio do incentivo às exportações agrícolas e do abandono de gastos com a produção industrial. ${ }^{245}$

\section{Conclusão}

As inovações que Calógeras levou para o Ministério da Fazenda resultaram em liberdade inédita na pasta que pode negociar opções em contratos internacionais que permitissem ao Brasil ter acesso a recursos em moeda conversível. Estas negociações esbarraram sempre nas limitações impostas pelo Reino Unido ao desempenho do Brasil no mercado internacional. A dívida que o Brasil tinha registrada em Londres impediu Calógeras de firmar acordos com outras praças financeiras internacionais.

A guerra teve o poder de mudar a forma como Calógeras entendia que deveria ser a administração da economia. De defensor do metalismo, o ministro passou a organizador da grande mudança na economia brasileira durante a guerra que foi a volta das emissões de moeda sem lastro. Esta mudança poderia ter provocado forte oscilação no câmbio, mas os recursos do funding loan reduziram a queda no valor do mil-réis frete à libra inglesa.

A necessidade de crédito, de ampliação da base monetária e de administração da taxa cambial foram temas bastante recorrentes no Brasil entre 1914 e 1918. Estas questões formaram a pauta que Sabino Barroso, Pandiá Calógeras e Antonio Carlos de Andrada tentaram deliberar por meio da expansão do Banco do Brasil, instituição herdeira de homônimas do Império e que foi obrigada a alterar procedimentos e a ocupar lugar de destaque na política econômica do país. Em uma época na qual ainda se debatia a validade de um banco central, o desempenho do Banco do Brasil foi imprescindível para o relacionamento do Brasil com o sistema financeiro internacional durante a guerra, objeto da análise contida no próximo capítulo.

\footnotetext{
${ }^{245}$ O Estado de S. Paulo, 18 julho 1915, p. 1.
} 


\section{Capítulo 6 - Atuação do Banco do Brasil no setor externo da economia brasileira}

Durante a guerra, o Banco do Brasil teve as suas atividades ampliadas de maneira inédita. A instituição passou a ser a maior responsável por encontrar soluções para a escassez de ouro. Foi neste período que o banco se transformou no interlocutor brasileiro junto às casas bancárias Rothschild e Schröder. Nestes encontros, os emissários do Banco do Brasil tiveram a oportunidade de vislumbrar opções de negócios em outras praças financeiras internacionais, como Nova York.

Com o fim da Caixa de Conversão, coube ao Banco do Brasil administrar o câmbio no país. Isto foi feito com a utilização de recursos públicos, motivo da distanciação entre as cotações praticas pelo banco e pelo mercado. O intuito era equilibrar as exportações que traziam as divisas e a s importações que forneciam as receitas. Este equilíbrio não foi simples.

Para evitar a falta de recursos em ouro, o Banco do Brasil instituiu o certificado-ouro. Era uma forma de o governo ter acesso ao imposto de importação de maneira antecipada e que permitisse ao país evitar os períodos de baixa na entrada do recurso. Esta ligação do banco com o setor externo durante a guerra incluiu a administração da conta da dívida externa do Brasil em Londres. Esta conta simbolizou a dependência do Brasil dos dispositivos fixados pelo Reino Unido para a economia internacional durante a guerra.

Seção 6.1 - O processo de ascensão do Banco do Brasil no setor externo brasileiro

O Banco do Brasil que atuou durante a guerra foi herdeiro do Banco da República do Brasil que teve atividades iniciadas após a regulamentação do decreto nº 6.169 de 31 de outubro de 1906. Este decreto estabeleceu a prerrogativa de o governo, como acionista majoritário, nomear tanto o presidente da nova instituição quanto o diretor da Carteira de Câmbio. A preocupação em fazer valer o voto do poder executivo na área de câmbio demonstra a importância que o setor externo tinha para a administração do país. Devido à atuação na área cambial, o Banco do Brasil se tornou instituição-chave para a política econômica brasileira durante a guerra porque passou a receber depósitos em ouro, entregar 
aos depositantes notas conversíveis fornecidas pela Caixa de Conversão, emitir cheques-ouro e requisitar notas conversíveis da Caixa de Amortização. ${ }^{246}$

A relação do Banco do Brasil com a economia internacional se consolidou com a realização do Convênio de Taubaté e o estabelecimento da Caixa de Conversão porque foram delegadas ao banco as operações de moeda conversível com o mercado, caracterizado até outubro de 1917 por liberdade nas transações cambiais. O Banco do Brasil passou a receber depósitos das exportações, emitir certificados para a liquidação das importações e a manter recursos conversíveis em caixa para a regulação da base monetária. ${ }^{247}$

Foi responsabilidade do Banco do Brasil administrar a partir de 1914 o fim das emissões da Caixa de Conversões das cédulas-ouro e a volta das emissões de moeda em curso forçado, prática que havia sido interrompida em 1898. Para justificar aos credores internacionais o fim da experiência brasileira com o padrão-ouro na margem e o retorno da heterodoxia, o governo culpou a situação internacional que não permitia mais o funcionamento da economia nos moldes nos quais o país estava habituado. Com o bloqueio dos recursos em moeda forte nos países de origem, a única saída era a emissão de moeda inconversível. Londres registrou e lamentou o fato, mas não adotou medidas punitivas como aumento de juros sobre a dívida brasileira.

Naquele momento, o Reino Unido estava enfrentando problemas em sua própria economia que exigiam atenção especial. A guerra trouxe problemas sérios que o governo britânico deveria enfrentar na economia internacional, como o espaço que o capital norteamericano passara a ocupar no mundo. Preocupações também sobre os recursos para fazer frente aos gastos bélicos que eram frequentemente recalculados e majorados a cada retorno de incursão militar nos frontes da guerra. Estas questões eram comuns aos outros países europeus, razão pela qual passou a ser rotina a emissão sem lastro como meio de enfrentar o déficit orçamentário. ${ }^{248}$

A participação do Banco do Brasil para a liquidação de dívidas em ouro passou a ser vital porque a redução na arrecadação aduaneira e o regime de exceção na liquidez

\footnotetext{
${ }^{246}$ A Caixa de Amortização foi criada em 1827 para administrar a dívida pública fundada nacional, atividade que exerceu até o início das operações do Banco Central do Brasil em 1967. Ver: http://www.receita.fazenda.gov.br/Memoria/administracao/reparticoes/1822a1970/caixas.asp

${ }^{247}$ História do Banco do Brasil. Diretoria de Marketing e Comunicação do Banco do Brasil, p. 113-4.

${ }^{248}$ Rothbard, The Monetary Breakdown of the West; Monthly Report on Prices, 20 julho 1920, MAF 60/264, nr. 09.
} 
internacional exigiram muita criatividade da instituição. Homero Baptista foi presidente do Banco do Brasil entre o final de 1914 e o início de 1919, quando coube ao Banco do Brasil providenciar todas as remessas do governo para o pagamento do serviço da dívida externa em valor que em 1915 foi de aproximadamente $£ 5$ milhões. ${ }^{249}$ O vínculo do Banco do Brasil com o setor externo da economia era estreito porque seguia além da relação com os credores internacionais. O banco operava como uma espécie de balizador do câmbio, tanto que o mercado financeiro nacional aguardava a taxa que seria praticada pela instituição na compra e na venda de divisas para então fixar as suas próprias taxas. ${ }^{250}$

Quando havia divergência elevada entre os preços do Banco do Brasil e dos bancos privados para a libra esterlina, o fato gerava discussões na imprensa porque o mercado acreditava que a origem de preços diferentes para a moeda inglesa eram as especulações provocadas pelos bancos estrangeiros. Estas instituições eram acusadas de forçar as oscilações para aumentar os seus lucros. Foi o que ocorreu em agosto de 1916 entre as taxas praticadas pelo Banco do Brasil para as letras de exportação e as taxas de mercado para as importações. $^{251}$

A falta de divisas transformou o Banco do Brasil em um importante aliado do governo federal porque o banco era o operador do sistema de certificados-ouro. O mecanismo foi criado para antecipar o recebimento de direitos aduaneiros: o Tesouro Nacional emitia os títulos para o pagamento do imposto em ouro nas alfândegas na União, ficando a cargo do Banco do Brasil controlar a carteira e efetuar os resgates destes títulos que em 1915 somaram $£$ 5.118.388 em novas emissões. A lógica desta operação implicava saldo zero porque as emissões de novos valores deveriam ser lastreadas no valor efetivo dos direitos aduaneiros, mas não foi o que se verificou e o saldo dos certificados sem contrapartida foi de cerca de $£$ 2.500.000 em 1915, apesar de o Banco do Brasil ter realizado resgate efetivo de $£$ 4.102.609..$^{252}$

\footnotetext{
249 "Banco do Brasil", Relatório do Ministério dos Negócios da Fazenda - 1915, p. 135.

${ }^{250}$ Para suas operações com moeda conversível durante a guerra, o Banco do Brasil efetuava retiradas regulares da Caixa de Conversão, como $£ 35.000$ em abril de 1915 noticiado em "Retirada da Caixa de Conversão", $O$ Estado de S. Paulo, 20 abril 1915, p. 1; "Ouro para o Banco do Brasil", noticiando saída de ouro da Caixa de Conversão para o Banco do Brasil no total de cinco mil contos. O Estado de S. Paulo, 20 junho 1915, p. 1.

251 "Moeda, circulação e câmbio", Retrospecto Commercial 1916, p. 92-3.

O Banco do Brasil era instado a atuar no mercado sempre que o sentido baixista da moeda se instalava, como ocorreu em setembro de 1915 em episódio que teve a participação do senador Leopoldo de Bulhões que pressionou por uma atitude enérgica junto ao câmbio que estava em ritmo muito avançado e mercado acreditava que a única esperança estava nas mãos do Banco do Brasil. O Estado de S. Paulo, 4 setembro 1915, p. 1.

252 "Banco do Brasil", Relatório do Ministério dos Negócios da Fazenda - 1915, p. 136.
} 
A chamada conta do serviço de certificados-ouro era motivo de preocupação e o Banco do Brasil tentava reduzir o valor ao patamar suficiente apenas para o giro da operação. De fato, os dados divulgados pelo Ministério da Fazenda realçam este esforço, mas as reduções nas emissões foram devidas à crise e não a possíveis restrições impostas pela política econômica. A tabela 6.1 compara as emissões dos certificados-ouro com as importações entre 1909 e 1915 e as variações anuais. Desse modo, é possível verificar que quando a guerra se iniciou em 1914, os recursos obtidos com as emissões de certificados-ouro foram reduzidos praticamente à metade do ano anterior. Dadas as limitações operacionais impostas pela Entente, no ano seguinte houve retração ainda maior, levando o total a representar aproximadamente 1/3 do montante verificado em 1913 para os certificados-ouro.

Tabela 6.1 - Emissão de certificados-ouro e importações, 1909-1915 (libras esterlinas)

Certificados-Ouro Var. \% Importações $\quad$ Var. \%

\begin{tabular}{l|r|r|r|r}
1909 & 9.187 .941 & & 37.139 & \\
1910 & 10.778 .531 & $17,31 \%$ & 47.872 & $28,90 \%$ \\
1911 & 12.970 .457 & $20,34 \%$ & 52.822 & $10,34 \%$ \\
1912 & 14.330 .671 & $10,49 \%$ & 63.425 & $20,07 \%$ \\
1913 & 14.007 .225 & $-2,26 \%$ & 67.166 & $5,90 \%$ \\
1914 & 7.375 .641 & $-47,34 \%$ & 35.473 & $-47,19 \%$ \\
1915 & 5.118 .388 & $-30,60 \%$ & 30.088 & $-15,18 \%$ \\
\hline
\end{tabular}

Fonte: "Banco do Brasil", Relatório do Ministério dos Negócios da Fazenda - 1915, p. 143; Estatísticas históricas do Brasil: séries econômicas, demográficas e sociais de 1550 a 1988.

2. ed. rev. e atual. do v. 3

Quando são observados os dados sobre as importações no mesmo período, é possível estabelecer uma relação entre os movimentos na emissão dos certificados e o comportamento das importações que geravam a base para a cobrança dos tributos aduaneiros, como em 1914 quando nos dois casos a retração ficou próxima a 50\%. Nos outros anos a similaridade nos números comprova a dependência deste mecanismo de financiamento em ouro que era administrado pelo Banco do Brasil e que ajudou o país a enfrentar as crises e a sazonalidade cambial brasileira, típica de países com preponderância de produtos agrícolas na pauta de exportações.

Durante a guerra, o Banco do Brasil também atuou em parceria com o Tesouro Nacional junto aos principais setores exportadores do período para evitar a redução da entrada de divisas. Isto ocorreu, por exemplo, em São Paulo quando o banco repassou Rs 150:000\$000 para regular o preço do café por meio da compra do excedente do produto pelo 
governo do estado de São Paulo. Atuação similar do Banco do Brasil foi verificada em Belém e em Manaus. Nestas regiões, o foco foi o mercado da borracha para o qual foram transferidas aplicações que totalizaram Rs. 15:000\$000. O objetivo era resolver o problema da produção estocada que estava deprimindo as cotações do produto. ${ }^{253}$ Especificamente no caso da borracha, o Banco do Brasil atuava como agente regulador no mercado, emprestando recursos para que os empreendimentos neste setor pudessem suportar os baixos preços praticados no comércio internacional. Os recursos acabavam tendo como destino final a cobertura de saques e o fornecimento de suprimentos para as frentes de produção. ${ }^{254}$

A demanda por ouro para o pagamento de compromissos no exterior era de tal ordem que mercadorias obtidas pelo Banco do Brasil por falta de pagamento podiam ser exportadas e o valor transferido para a conta que o banco mantinha em Londres. Esta conta era destinada às transações entre a instituição brasileira e os banqueiros internacionais. Os recursos em ouro eram utilizados como base para empréstimos subsidiados à produção nacional, agrícola ou industrial. Os valores referentes ao pagamento dos juros destes empréstimos, assim como a liquidação de parcelas das dívidas, deveriam ser remetidos para esta conta visando à restituição do fundo de garantia. A criatividade para a obtenção de cambiais levou o Banco do Brasil a comprar café com emissão de moeda para venda ao governo francês e a liquidação do contrato cambial da exportação foi mantida no exterior como parte do pagamento dos juros da dívida externa. Nesta operação foram transacionadas 250 mil sacas de café que renderam Rs. $15: 000 \$ 000 .{ }^{255}$

O Banco do Brasil agiu também para saldar a dívida corrente junto aos bancos europeus no balanço do ano de 1914 , que era de cerca de $£ 1$ milhão e que muita pressão provocava no Ministério da Fazenda. Como a taxa em dólar estava favorável em relação à libra esterlina e como as exportações de café para o mercado norte-americano tinham atingido volume expressivo, o Banco do Brasil tentou uma operação diversificada na qual foram realizadas remessas de cambiais a partir de Nova York e o passivo corrente com os banqueiros europeus encerrado, com exceção de valor que estava pendente junto ao Norddeutsche Bank que registrava crédito a favor do Brasil no total de $£ 23.000$, valor suficiente para cobrir o saldo devedor. A regularização deste débito não foi possível por causa das restrições de guerra impostas pelos países da Entente que passaram a exercer bloqueio nos

\footnotetext{
${ }^{253}$ História do Banco do Brasil, Ibidem, p. 119.

254 "Carta de Delegados de associações comerciais do Pará e do Amazonas", O Estado de S. Paulo, 03 fevereiro 1915 , p. 3

255 “Banco do Brasil”, Relatório do Ministério dos Negócios da Fazenda - 1915’, p. 135-144.
} 
bancos do Império Alemão e aliados. Como Brasil se submetia às definições de política internacional de Londres e Paris a pendência com este banco alemão permaneceu. Este caso deixa patente o posicionamento brasileiro de adesão às causas de Paris e Londres no conflito, mas camuflada de neutralidade. Esta dubiedade nas relações exteriores durante a maior parte da guerra servia para não causar prejuízos ainda maiores ao comércio exterior brasileiro do pós-guerra em futuro que se acreditava próximo. Uma declaração de guerra implicaria no distanciamento formal do mercado alemão após o armistício, opção que não atendia aos anseios nacionais tal como os agentes econômicos desejavam. Este quadro levou o Brasil a adiar o quanto pode o fim da sua condição de país neutro.

Operações especiais de crédito com países da Aliança não podiam ser liquidadas porque os valores internados no Brasil dependiam de aval dos bancos centrais envolvidos. Se o caso tivesse a participação de capital alemão - situação frequente devido aos negócios com o café - a tendência era a de os valores ficarem retidos com o Banco Central da Alemanha porque o Brasil era um país neutro ligado aos países da Entente. Neste cenário de neutralidade disfarçada, o Banco do Brasil agia no exterior como um agente executivo das operações com títulos em moeda-ouro e sempre em contato direto com o Rothschild tentando encontrar credores - em alguns casos, famílias - para negociar juros, novos prazos de pagamento e demais tratativas típicas de um agente financeiro internacional. Apesar da criticidade da situação e das muitas restrições financeiras internas e externas, os exercícios posteriores ao início da guerra não foram de resultados ruins para o Banco do Brasil. A instituição conseguiu aumentar a margem de lucro e expandir operações de crédito em 1917, melhorando a atuação junto ao comércio e à indústria, aumentando a oferta de moeda e financiando novos empreendimentos. $^{256}$

\section{Seção 6.2 - A especialização do Banco do Brasil em negócios internacionais}

Apesar da proximidade e da simbiose com o governo federal, relatórios do Banco do Brasil ousavam levantar críticas à política econômica, especialmente em relação à situação do comércio exterior, que foi área de destaque da instituição até a transferência da Câmara de Comércio Exterior (CACEX) para a Secretaria de Comércio Exterior (SECEX) no início dos anos 1990. Caso de crítica recorrente foi o fato de que o país importava borracha e sal em

\footnotetext{
256 “Banco do Brasil”, Relatório do Ministério dos Negócios da Fazenda - 1917, p.37-47.
} 
quantidades elevadas para um grande produtor mundial dos dois insumos. O Banco do Brasil defendia que o país deveria aproveitar a recuperação do comércio internacional e abrir novas frentes de negócios, mas este discurso não encontrava apoio suficiente junto ao governo brasileiro porque os valores dos produtos que o país mais exportava - café, borracha e cacau estavam reduzidos por força das circunstâncias da guerra. Na outra ponta do comércio externo, o valor médio da tonelada importada aumentou em tal grau que atingiu em 1917 o dobro do valor médio praticado em 1913.

A posição do Banco do Brasil indicava que se não fossem as limitações logísticas internas e externas, o comércio exterior brasileiro poderia ter se expandido ainda mais, auxiliando setores da economia que vivenciavam forte depressão. O Banco do Brasil ressaltava que as possibilidades perdidas por falta de condições logísticas internas do país não tinham relação com a guerra e as restrições internacionais dela advindas. Dada a carência de infraestrutura interna, a economia brasileira ficava alijada diante do novo tipo de demanda que a guerra propiciava, como minério de ferro, carvão de pedra, energia a partir das quedas d'água, fibras, manganês e cereais. O Banco do Brasil enfatizava que o manganês e os cereais tinham demanda imediata, mas não seriam exportados por falta de condições de escoamento da produção. O problema logístico era potencializado pela falta de combustíveis, mas o Banco do Brasil acreditava que o cenário poderia ser alterado se a ampliação da estrutura ferroviária fosse empreendida, principalmente com a instalação de ramais no Paraná e em Santa Catarina que beneficiariam diretamente a exploração do carvão de pedra e do minério de ferro. ${ }^{257} \mathrm{O}$ carvão de pedra, além das cambiais que traria aos cofres públicos com as exportações, poderia atenuar o grande empecilho à integração nacional que se ressentia da falta de navegação de cabotagem.

Quando das negociações para que o Brasil cedesse à Entente navios alemães ancorados em portos do país, nota do presidente do Banco do Brasil criticou de maneira aberta o governo porque o episódio poderia ter rendido muito mais que a venda de dois milhões de sacas de café e a aplicação de cem milhões de francos na exportação de cereais. Poderia incluir produtos de pauta certa para as exportações, como o cacau e a borracha. No caso da borracha, o banco acreditava que esta talvez tivesse sido a última oportunidade para que o fim do ciclo do produto se consumasse.

\footnotetext{
257 “Banco do Brasil”, 'Relatório do Ministério dos Negócios da Fazenda - 1917', p.37-47.
} 
O Banco do Brasil entrou em campanha em 1917 para a aprovação do projeto de instalação de três agências no exterior: Londres, Buenos Aires e Montevideo. Na defesa desta estratégia de internacionalização, o banco afirmava que o Brasil era caso de exceção porque atuava em Londres - praça financeira que concentrava a maior parte dos contratos brasileiros no exterior - por intermédio de uma Delegacia do Tesouro, enquanto muitos países que também tinham interesses econômicos de vulto na Europa atuavam com apoio de bancos de confiança. O Banco do Brasil aproveitava para fazer apologia na distinção entre o foco do trabalho da Embaixada do Brasil no Reino Unido, e o papel desempenhado pelo banco que era de natureza estritamente econômica, coadunando com os muitos negócios de caráter financeiro e produtivo que o país realizava no exterior. A instalação de embaixadas especiais era prática desaconselhada pelo Banco do Brasil porque o custo era elevado demais e os resultados incertos porque estes postos sofriam por falta de vivência no mundo corporativo e por não terem o lucro como meta. O banco aproveitava o período de guerra, quando o preço de algumas commodities se elevava constantemente, para justificar a expansão de agências no exterior porque estas operariam como captadoras de negócios e de recursos em ouro, exatamente quando o país mais necessitava de meios para arcar com os preços muito acima da média histórica dos bens importados. A estimava da diretoria do Banco do Brasil era que seriam necessários dois milhões de libras para a operação de expansão internacional no curto prazo, sendo um milhão para a instalação da agência em Londres, setecentas mil libras para a praça de Buenos Aires e trezentas mil para operações em Montevideo. ${ }^{258}$

Apesar de toda a movimentação entre os escalões do poder, estas investidas de expansão do Banco do Brasil no exterior permaneceram apenas como intenções. As atribulações financeiras pelas quais o país passou durante e logo após a guerra restringiram a atuação da instituição à América do Sul. A primeira agência internacional foi aberta em Assunção em 1941, seguida por Montevidéu em 1946. As operações nas praças de Buenos Aires e Londres faziam parte do projeto inicial de expansão pensado e divulgado durante a guerra, mas tiveram atividades iniciadas apenas em 1959 e 1971, respectivamente. ${ }^{259}$ Estes fatos indicam que as muitas tratativas que o Banco do Brasil teve que realizar em Londres durante a guerra se deram com suporte da Embaixada do Brasil e da base que o N.M. Rothschild mantinha na City.

\footnotetext{
258 "Banco do Brasil”, Relatório do Ministério dos Negócios da Fazenda - 1917, p. 37-47.

${ }^{259}$. História do Banco do Brasil. Ibidem, p. 186.
} 
Uma das responsabilidades do Banco do Brasil durante a guerra era entregar semanalmente para o governo letras em ouro, prática identificada no mercado como um dos motivos para a baixa no câmbio. $\mathrm{O}$ fato é que os problemas no setor externo da economia brasileira estavam se acumulando e incluíam obstáculos à exportação de café e ao aumento das importações, além do que o clima de guerra piorava constantemente. Agora o receio era que a conflagração mundial pudesse se estender por ainda muito tempo, suscitando maior necessidade de entesouramento no mercado financeiro internacional, diminuindo a entrada de ouro no Brasil.

Após muita especulação, o ingresso da Bulgária na guerra derrubou ainda mais o valor do mil-réis a partir de outubro de 1915 porque o mercado decodificou o evento como sinal de prolongamento das atividades bélicas. A contaminação por fatos negativos externos impedia o Banco do Brasil de manter regularidade nas operações junto ao mercado cambial, problema que o comércio acreditava ser o ingrediente que alimentava a especulação no câmbio e que forçava baixas que poderiam ter sido evitadas. As esperanças ficaram concentradas na continuidade do aumento das vendas de café nos Estados Unidos e na Europa que ampliara a proibição do consumo de álcool enquanto durasse a guerra. Isto significava mais portas abertas para o café brasileiro. ${ }^{260}$

A crise provocada com a carência de ouro fez o Banco do Brasil tentar se preparar para a volta das remessas de divisas para pagamento do serviço da dívida externa em 1917, como previsto no contrato do funding loan. Como o banco havia sido imbuído do controle absoluto na área externa da economia brasileira, tudo o que se referia ao câmbio, a investimentos estrangeiros e aos empréstimos externos lembrava à sociedade o grau de responsabilidade da instituição e mostrava que o banco parecia cada vez mais sitiado frente à especulação em escala inédita durante os conflitos. O presidente do Banco do Brasil era constantemente indagado sobre quais eram os planos da instituição para administrar o câmbio quando o país voltasse a pagar juros e amortização da dívida externa. Enquanto isto, a taxa cambial ensaiava novo nível de desvalorização. No início de 1916, um dos piores momentos da crise, a libra passou a valer 11,56d, valor que foi o mais baixo entre janeiro de 1915 e dezembro de 1917, como indicado na Tabela 6.2. O problema não era apenas o sentido de baixa da moeda, mas essencialmente o de oscilação que respondia à especulação e levou a cotação do mil-réis à valorização expressiva em maio de 1917. Esta queda no valor da libra

\footnotetext{
260 “A queda no câmbio”, O Estado de S. Paulo, 23 janeiro 1916, p. 2.
} 
foi reflexo de novidades positivas nas negociações do café que estava estocado em Hamburgo, de notícias sobre a redução na dívida externa brasileira e até de conjecturas sobre acordos de paz na Europa. ${ }^{261}$ As incertezas eram tantas que qualquer rumor, especialmente originado nas praças financeiras europeias, alterava o câmbio no Brasil e ampliava os efeitos negativos nos negócios.

Tabela 6.2 - Taxa de câmbio média mensal da libra esterlina, 1915-1917, Rio de Janeiro (réis por pence)

\begin{tabular}{|c|c|c|c|c|c|}
\hline \multicolumn{4}{|c|}{ Var. \% } & \multicolumn{2}{|c|}{ Var. \% } \\
\hline $\mathrm{jan} / 15$ & 13,87 & & jul/16 & 12,59 & $2,36 \%$ \\
\hline $\mathrm{fev} / 15$ & 12,75 & $-8,07 \%$ & ago/16 & 12,56 & $-0,24 \%$ \\
\hline $\mathrm{mar} / 15$ & 13,01 & $2,04 \%$ & set/16 & 12,36 & $-1,59 \%$ \\
\hline $\mathrm{abr} / 15$ & 12,20 & $-6,23 \%$ & out/16 & 12,19 & $-1,38 \%$ \\
\hline mai/15 & 12,28 & $0,66 \%$ & nov/16 & 12,00 & $-1,56 \%$ \\
\hline jun/15 & 12,42 & $1,14 \%$ & dez/16 & 11,97 & $-0,25 \%$ \\
\hline $\mathrm{jul} / 15$ & 12,83 & $3,30 \%$ & $\mathrm{jan} / 17$ & 12,00 & $0,25 \%$ \\
\hline ago/15 & 12,31 & $-4,05 \%$ & fev/17 & 11,89 & $-0,92 \%$ \\
\hline $\mathrm{set} / 15$ & 12,09 & $-1,79 \%$ & $\operatorname{mar} / 17$ & 11,84 & $-0,42 \%$ \\
\hline out/15 & 12,25 & $1,32 \%$ & $\mathrm{abr} / 17$ & 12,05 & $1,77 \%$ \\
\hline nov/15 & 12,25 & $0,00 \%$ & mai/17 & 13,31 & $10,46 \%$ \\
\hline $\mathrm{dez} / 15$ & 12,09 & $-1,31 \%$ & jun/17 & 13,66 & $2,63 \%$ \\
\hline $\mathrm{jan} / 16$ & 11,56 & $-4,38 \%$ & $\mathrm{jul} / 17$ & 13,36 & $-2,20 \%$ \\
\hline $\mathrm{fev} / 16$ & 11,67 & $0,95 \%$ & ago/17 & 13,05 & $-2,32 \%$ \\
\hline $\mathrm{mar} / 16$ & 11,73 & $0,51 \%$ & set/17 & 12,86 & $-1,46 \%$ \\
\hline $\mathrm{abr} / 16$ & 11,64 & $-0,77 \%$ & out $/ 17$ & 13,05 & $1,48 \%$ \\
\hline mai/16 & 12,05 & $3,52 \%$ & nov/17 & 13,12 & $\begin{array}{l}0,54 \% \\
4,34 \%\end{array}$ \\
\hline jun/16 & 12,30 & $2,07 \%$ & dez/17 & 13,69 & \\
\hline
\end{tabular}

Fonte: IBGE, Tabela II - Curso do câmbio na Praça do Rio de Janeiro - 1822/1939, p. 63.

O grupo de empresário com dependência direta das importações era a maioria do comércio varejista nacional. Eles pressionavam o governo e o Banco do Brasil para que se tentasse prorrogar o pagamento do serviço da dívida externa, solução paliativa que visava impedir a continuidade da desvalorização, especialmente em 1916 que começou com queda próxima a 5\%. Uma destas diligências que talvez tenha sido a que mais a sério tenha sido

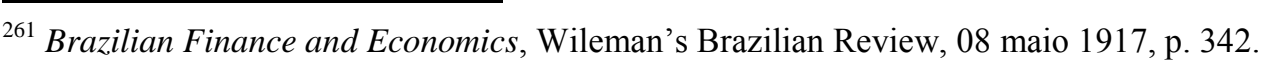


analisada pelos banqueiros do funding foi a que tentou prorrogar o desencaixe do ouro por mais três anos utilizando como garantia recursos da renda aduaneira, mesmo que de portos que não estavam em obras de melhoria, mesmo que relacionados a obras não financiadas com recursos externos. A arrecadação em moeda conversível seria depositada em conta especial e vinculada aos credores no Banco do Brasil, mas banqueiros britânicos e franceses exigiam que qualquer possível repactuação do funding deveria incluir a participação de representantes destes bancos na administração do Banco do Brasil como forma de assegurar o controle das reservas e dos repasses ao exterior. ${ }^{262}$ Não houve a repactuação do funding, os serviços da dívida voltaram a ser liquidados, e em 1919 ainda foi aplicada a famosa cláusula de amortização que previa que o Rothschild poderia utilizar percentual do funding para a aquisição de títulos do empréstimo de rescisão das garantias ferroviárias de 1901, tema polêmico na historiografia econômica brasileira. ${ }^{263}$

Em face da carência de recursos externos e das demandas para que o fluxo monetário fosse ampliado, a ideia de Homero Baptista de transformar o Banco do Brasil em banco emissor causou bastante interesse no comércio. O projeto era basicamente emitir moeda apenas de "acordo com a necessidade da economia". Na opinião que o presidente do Banco do Brasil fez chegar aos acionistas, nenhuma instituição era mais bem preparada para monitorar a necessidade de moeda da economia que o Banco do Brasil. ${ }^{264} \mathrm{O}$ que se pretendia era que o banco voltasse à condição de emissor de papel moeda, posição de destaque na economia que os bancos antecessores que também ostentaram o nome Banco do Brasil desfrutaram ainda durante o Império - entre 1853 e 1866 - e no início da Era Republicana, entre 1892 e 1896. A tentativa de outorgar ao Banco do Brasil esta prerrogativa causou discussão no mercado, mas ao final acabou prevalecendo a opinião que o país necessitava mesmo era de um banco emissor nos moldes do Reichsbank. De acordo com o ex-ministro da Fazenda, Rivadavia Correa, este banco não deveria ser o Banco do Brasil, mas sim uma instituição financeira criada especialmente para tal propósito como ocorrera com o Banco Central Alemão, criado logo após a unificação do país e que já nasceu com o intuito de preservar o valor do marco alemão. O projeto do Banco do Brasil foi arquivado e somente

\footnotetext{
262 "Sessão semanal na Associação Commercial do Rio de Janeiro - Discurso do Sr. Sampaio Correa - O relatório da commissão especial”, O Estado de S. Paulo, 01 setembro 1916, p.5.

${ }^{263}$ Ver Abreu, Brasil, 1824-1957: bom ou mau pagador, p. 11-7; Cavalcanti, Histórico da Dívida Externa Federal, p. 60-5.

264 “Assembleia geral de acionistas do Banco do Brasil - as propostas apresentadas", Estado de S. Paulo, 01 maio 1917 , p. 4.
} 
após o fim da guerra o banco voltaria à condição de emissor de moeda, mesmo que durante curto espaço de tempo. ${ }^{265}$

Caso bastante sintomático das tentativas das autoridades brasileiras em conseguir receitas em ouro foi a intrincada operação levada a termo pelo Banco do Brasil em Londres que objetivou firmar um empréstimo externo em valor que começou em $£ 6$ milhões, foi reduzido à metade, se transformou em $£ 5$ milhões e muita polêmica gerou em Londres. A origem do caso emblemático está relacionada à empresa Jacob Walter \& Company, grande empreendimento mercantil diretamente envolvido com comércio exterior que atuava havia mais de quarenta anos no Brasil e acabou por desenvolver contatos importantes no Banco do Brasil. ${ }^{266}$ A empresa com sede em Londres foi contratada pelo Banco do Brasil a pedido do governo brasileiro para facilitar os trâmites de empréstimo que seria pleiteado em bancos britânicos. O emissário do Banco do Brasil era Francis. H. Walter, sócio da empresa em questão que era credora do Brasil. Esta informação foi omitida até o fim das negociações, até mesmo diante do Departamento de Comércio da Guerra que analisava a concessão de recursos ao exterior e cercava as possibilidades de que recursos em ouro terminassem nas mãos dos inimigos. $^{267}$

Empréstimos durante a guerra para países neutros tinham que ser aprovados pelo Tesouro Britânico e pelo Departamento de Comércio da Guerra, levando os processos a um labirinto de vetos e condicionantes sem fim. Foi o que ocorreu com esta empreitada do Banco do Brasil que acabou arquivada pelas autoridades britânicas desconfiadas de uma operação na qual o representante do banco era, como posteriormente descoberto, o maior interessado na liberação dos recursos. Este é apenas um exemplo de como a economia brasileira foi conduzida durante a conflagração, período que exigiu mecanismos improvisados de negociação para países neutros com déficits em ouro que tentavam driblar as barreiras que os países da Entente construíram ao longo do conflito visando sufocar financeiramente os países da Aliança. Este novo arranjo da economia internacional significou limitações para bancos como o Rothschild que apesar da experiência de financiamento adquirida em outras guerras não conseguiu se estruturar para atender a demanda por negócios multifacetados e que exigiam grau de criatividade mais agressivo. As mudanças nas operações de financiamento

\footnotetext{
265 “O papel moeda”, História da Moeda. Publicação do Banco do Brasil.

O Estado de S. Paulo, 10 maio 1917, p. 2.

${ }^{266}$ Banking Facilities for Bank of Brazil, maio 1915, T 1/11865/10907, carta de Jacob Walter \& Co. de 16 abril 1915.

${ }^{267}$ Bank of Brazil, pasta especial do Tesouro Britânico sobre o Banco do Brasil, maio de 1915, T 1/11865/10907.
} 
internacional foram interpretadas como um sinal para que bancos norte-americanos identificados como mais dispostos a adaptações e com grande foco na expansão mundial se prontificassem a intermediar interesses financeiros internacionais menos ortodoxos, como se verificava no Brasil.

A política econômica do Brasil mudou durante a guerra ao voltar a emitir moeda em curso forçado para a compra de café excedente e que não podia mais ser negociado nas mesmas bases de antes de 1914. A lógica da operação era adquirir o produto no mercado nacional, gerar renda interna e exportar o produto para estoques estratégicos que o país mantinha nos Estados Unidos e na Europa. Em relação à logística internacional, o posto avançado mais importante para o café brasileiro era o porto de Hamburgo que contava com as melhores condições de armazenar e despachar o café brasileiro para mercados consumidores na Europa e na Ásia. O problema era que este importante braço operacional do comércio exterior brasileiro foi colocado fora de procedimento com as imposições da Entente sobre os interesses econômicos do Império Alemão. A subtração de Hamburgo do sistema de negociação que a economia cafeeira montara comprometeu em muito a continuidade destas operações que visavam atender os interesses da economia cafeeira, mas eram também fundamentais para a economia brasileira. Com a guerra modificando os protocolos do comércio exterior, o Banco do Brasil ganhava mais espaço porque saídas criativas tinham que ser buscadas. ${ }^{268}$ A ascensão do Banco do Brasil como negociador de créditos para o Brasil coincidiu com o declínio do poder do Rothschild junto ao governo brasileiro porque a casa bancária dos Rothschilds estava pressionada em seus mercados habituais por banqueiros de Nova York e acabou por se envolver em operações de financiamento de guerra em outros mercados que antes não faziam parte da área principal da empresa, como foi o caso das novas relações que eles estabeleceram com o governo russo. ${ }^{269}$

O Banco do Brasil ascendeu em importância econômica durante os confrontos mundiais porque o comércio exterior passou a ser praticamente a única forma de diálogo do Brasil na economia internacional. Neste momento de guerra, os banqueiros eram consultados pelo Banco do Brasil sobre a possibilidade da abertura de crédito em favor do banco brasileiro, mas os banqueiros britânicos somente concordavam em dar passos efetivos na direção da liberação de recursos se previamente houvesse um convite do governo britânico

268 Attitude of His Majesty's Government towards Brazil, março 1915, T1/11865/6463, carta do Tesouro Britânico, 02 fevereiro 1915.

${ }^{269}$ Business during the war, The Rothschild Archive. 
para tanto. Nestas situações, o Tesouro Britânico passava a ser o responsável pela operação e o Banco do Brasil entrava com as garantias necessárias, geralmente a renda aduaneira que era administrada pelo banco. Operações nestes termos prescindiam de anuência do Banco da Inglaterra. ${ }^{270}$

As cada vez mais constantes recusas das autoridades britânicas em permitir que novos créditos fossem concedidos ao Brasil neutro propiciaram maior participação do Banco do Brasil nas negociações da oferta do excedente da produção de café que se transformou em uma das raras brechas para a liberação de ouro junto ao governo britânico. O café era exportado para o Reino Unido, os recursos correspondentes liberados ao Brasil, e Londres ganhava no mercado futuro com a comercialização de uma commodity de alta liquidez. A diplomacia britânica indicava este tipo de operação que contava com algum grau de simpatia junto à opinião pública britânica, diferentemente do que se passava quando o mote era exclusivamente a concessão de empréstimo para um país como o Brasil que insistia na manutenção da posição de neutralidade. O Banco do Brasil utilizava nestas operações um elemento de convencimento poderoso junto às autoridades britânicas ao demonstrar como um malogro poderia ser visto pelos especuladores como sinal que a depressão no câmbio brasileiro não teria fim, vitimando essencialmente o comércio importador. O Banco do Brasil era o responsável para a concessão das autorizações de importações, o que deixava a instituição envolvida em praticamente todo o processo do comércio importador. Isto permitia ao banco oferecer aos exportadores britânicos um cenário de negócios mais propício no Brasil, com vantagens diferenciadas, uma maneira tortuosa de obter apoio e pressão de empresários britânicos para solicitações de exportações especiais de café do Brasil. ${ }^{271} \mathrm{Um}$ dos efeitos colaterais destas negociações que colocavam o café como moeda de troca para financiamentos em ouro foi o da distorção dos valores reais do mercado internacional do produto durante a guerra, porque muito café acabou sendo exportado com defasagem em relação à demanda, isto é, a demanda por café não correspondeu à venda efetiva do produto no mercado internacional.

Recusar operações de crédito para atender anseios do governo brasileiro passou a ser uma tarefa delicada durante a guerra porque a provável negativa tinha que ser informada com um cuidado que não existia antes de 1914. O governo Britânico ao dizer que não podia

\footnotetext{
${ }^{270}$ Attitude of His Majesty's Government towards Brazil, Op. Cit.

${ }^{271}$ Bank of Brazil - application by Jacob Walter \& Co., maio 1915, T 1/11865/10907, carta do Board of Trade, 29 março 1915.
} 
atender a demanda do Banco do Brasil em uma operação de crédito tentava deixar claro que o problema não era a falta de garantias por parte do Brasil, mas sim a falta de recursos na Europa. Quando a situação melhorasse, o governo britânico estaria pronto a ajudar o Brasil porque o país emitia sinais de amizade inequívoca nestes tempos difíceis. Os recursos para a concessão de ouro ao Banco do Brasil existiam, fossem na forma de repasses do Tesouro britânico de maneira direta ou indireta com apoio do Tesouro dos Estados Unidos. O que faltava para o sucesso das missões financeiras do Banco do Brasil eram garantias de que tais recursos não teriam o Império Alemão e seus aliados como destino final basicamente, porque o Brasil era visto na Europa como um país inclinado a se posicionar a favor da Alemanha por causa da força da imigração germânica que ocorrera na porção Sul do território nacional ao longo do século XIX. Garantir que nenhuma empresa de origem alemã - por capital ou por ascendência dos proprietários - teria acesso aos recursos repassados por bancos estrangeiros ao Banco do Brasil era tarefa praticamente impossível no Brasil durante a guerra.

Neste contexto, a venda do excesso da produção de café parecia adequada na opinião do governo britânico porque os recursos obtidos tendiam a ser canalizados para o governo brasileiro e chegariam ao mercado interno por intermédio das empresas ligadas ao café. Este raciocínio não eliminava o fato de que grandes corporações como a alemã Theodor Wille \& Cia, que atuava em diversas áreas do comércio internacional, fosse frequentemente arrolada como um dos maiores exportadores de café do Brasil. Esta corporação desenvolveu ao logo do século XIX ampla teia de contratos que levaram a empresa a operar inclusive no transporte marítimo entre Santos e Hamburgo. A dependência que os empresários brasileiros tinham dos negócios de Theodor Wille foi o grande elemento que acabou por transformar Hamburgo no mais importante destino para o café brasileiro até o início da guerra. Este porto registrou antes da guerra aproximadamente $30 \%$ do total exportado pelo Brasil, o dobro do porto de Havre na França, segundo colocado. ${ }^{272}$

Apesar da retórica, o Departamento de Comércio da Guerra se preocupava com a qualidade do Brasil como devedor internacional, fato que passou a ser elemento de peso na análise de solicitações de empréstimos durante a guerra. Como os recursos antes da guerra eram provenientes do sistema financeiro privado britânico, o risco do Brasil era calculado em juros que compensavam as transações. Com a guerra, o Tesouro Britânico passou a ser o avalista final dos recursos, cada vez mais escassos. Em carta, o Departamento de Comércio da

${ }^{272}$ O Estado de S. Paulo, 04 janeiro 1913, p. 6. 
Guerra explicitou que o Brasil representava risco duplo: inadimplência e de repassar recursos para as forças inimigas. Até mesmo tentativas do Banco do Brasil em transformar empréstimos em linhas de crédito para o comércio de exportação foram recusadas porque os bancos locais já tinham emitido notas contrárias a esta estratégia de acesso a recursos em moeda conversível. As garantias oferecidas pelo Brasil eram letras de curto prazo do Tesouro Nacional, papel que embutia risco considerado elevado pelos banqueiros britânicos. ${ }^{273}$

A busca por linhas de crédito para as exportações embutia uma estratégia ousada do Banco do Brasil que ultrapassava a viabilização do comércio exterior brasileiro porque o banco tentava diminuir a volatilidade da taxa cambial brasileira que no início de 1915 prenunciava uma deterioração do cenário econômico nacional. As variações cambiais eram obstáculo importante para o comércio exterior, especialmente para o mercado de importados, que além de configurar a base do comércio interno do país, fornecia o fato gerador para a renda aduaneira, principal tributo nacional. A Tabela 6.3 mostra como se comportou o câmbio no Brasil neste ambiente macroeconômico contagiado pelas mudanças trazidas com o desenrolar das batalhas na Europa.

Tabela 6.3 - Taxa cambial no Rio de Janeiro, 01 janeiro - 18 março 1915 (pence / mil-réis)

\begin{tabular}{ccc|c|c|c|c|c|c}
\hline $\begin{array}{c}\text { Janeiro } \\
\text { Dia }\end{array}$ & \multicolumn{1}{c}{ Cotação } & \multicolumn{1}{c}{ Var. \% } & \multicolumn{1}{c}{ Devereiro } & \multicolumn{2}{c}{ Cotação } & \multicolumn{2}{c}{ Var. \% } & \multicolumn{2}{c}{ Dia } & \multicolumn{2}{c}{ Cotação } & \multicolumn{1}{l}{ Var. \% } \\
\hline 1 & - & - & 1 & 13,69 & $0,44 \%$ & 1 & 12,69 & $-0,47 \%$ \\
2 & 14,09 & & 2 & 13,56 & $-0,95 \%$ & 2 & 12,69 & $0,00 \%$ \\
3 & - & - & 3 & 13,44 & $-0,88 \%$ & 3 & 12,81 & $0,95 \%$ \\
4 & 14,09 & & 4 & 13,19 & $-1,86 \%$ & 4 & 12,94 & $1,01 \%$ \\
5 & 14,09 & & 5 & 13,31 & $0,91 \%$ & 5 & 13,06 & $0,93 \%$ \\
6 & - & - & 6 & 13,16 & $-1,13 \%$ & 6 & 13,00 & $-0,46 \%$ \\
7 & 14,16 & $0,50 \%$ & 7 & - & - & 7 & - & - \\
8 & 14,19 & $0,21 \%$ & 8 & 13,17 & $0,08 \%$ & 8 & 13,00 & $0,00 \%$ \\
9 & 14,25 & $0,42 \%$ & 9 & 12,88 & $-2,20 \%$ & 9 & 13,06 & $0,46 \%$ \\
10 & - & - & 10 & 12,50 & $-2,95 \%$ & 10 & 13,06 & $0,00 \%$ \\
11 & 14,17 & $-0,56 \%$ & 11 & 12,69 & $1,52 \%$ & 11 & 13,38 & $2,45 \%$ \\
12 & 14,19 & $0,14 \%$ & 12 & 13,75 & $8,35 \%$ & 12 & 13,31 & $-0,52 \%$ \\
13 & 14,19 & $0,00 \%$ & 13 & 12,88 & $-6,33 \%$ & 13 & 13,12 & $-1,43 \%$ \\
14 & 14,19 & $0,00 \%$ & 14 & - & - & 14 & - & - \\
15 & 14,13 & $-0,42 \%$ & 15 & - & - & 15 & 13,25 & $0,99 \%$
\end{tabular}

${ }^{273}$ Banking Facilities for Bank of Brazil, maio 1915, T 1/11865/10907, carta do Trade Clearing House de 10 abril 1915. 


\begin{tabular}{l|c|c|c|c|c|c|c|c}
16 & 14,07 & $-0,42 \%$ & 16 & - & - & 16 & 13,44 & $1,43 \%$ \\
17 & - & - & 17 & 12,69 & $-1,48 \%$ & 17 & 13,56 & $0,89 \%$ \\
18 & 14,00 & $-0,50 \%$ & 18 & 12,50 & $-1,50 \%$ & 18 & 13,63 & $0,52 \%$ \\
19 & 13,91 & $-0,64 \%$ & 19 & 12,50 & $0,00 \%$ & 19 & & \\
20 & 13,91 & $0,00 \%$ & 20 & 12,50 & $0,00 \%$ & 20 & & \\
21 & 14,00 & $0,65 \%$ & 21 & - & - & 21 & & \\
22 & 14,00 & $0,00 \%$ & 22 & 12,63 & $1,04 \%$ & 22 & & \\
23 & 13,88 & $-0,86 \%$ & 23 & 12,56 & $-0,55 \%$ & 23 & & \\
24 & - & - & 24 & - & - & 24 & & \\
25 & 13,72 & $-1,15 \%$ & 25 & 12,53 & $-0,24 \%$ & 25 & & \\
26 & 13,91 & $1,38 \%$ & 26 & 12,69 & $1,28 \%$ & 26 & & \\
27 & 13,81 & $-0,72 \%$ & 27 & 12,75 & $0,47 \%$ & 27 & & \\
28 & 13,66 & $-1,09 \%$ & 28 & - & - & 28 & & \\
29 & 13,63 & $-0,22 \%$ & 29 & - & - & 29 & & \\
30 & - & - & 30 & - & - & 30 & \\
31 & - & - & 31 & - & - & 31 & & \\
\hline
\end{tabular}

Fonte: Bank of Brazil - Rio Exchange, maio 1915, T 1/11865/10907.

As incertezas na economia fizeram o câmbio em 1915 flutuar de maneira excessiva. O primeiro trimestre deste ano registrou valorizações e desvalorizações do mil-réis próximas a $3 \%$ em um único dia, como verificado nos dias 9 e 10 de fevereiro e em 11 de março daquele ano. O Banco do Brasil defendia em Londres que o grande desafio para a economia brasileira era estabilizar a taxa de câmbio que passou a oscilar com muito mais frequência após o início da guerra, inviabilizando grande parte do comércio exterior brasileiro e comprometendo as receitas da União em ouro. Este era o ponto para o qual o Banco do Brasil esperava maior impacto junto aos banqueiros internacionais dado que a principal garantia inventariada no contrato de funding loan de 1914 era justamente a receita com tributos de importação. Esta tentativa de obtenção de crédito em 1915 rendeu frutos, com o Banco Barings registrando junto ao Tesouro Britânico que estava disposto a conceder ao Banco do Brasil crédito pelo prazo de 90 dias, período estritamente necessário para liquidação imediata de operações de exportação. $^{274}$

Trabalhar com linhas de crédito de bancos de primeira linha no curtíssimo prazo é indicativo que a economia brasileira sentiu de maneira bastante negativa as consequências da guerra. A falta dos recursos em ouro das exportações levou as autoridades brasileiras a argumentar repetidamente que se empréstimos não eram possíveis naquele momento que

${ }^{274}$ Banking Facilities for Bank of Brazil, maio 1915, T 1/11865/10907, carta de Jacob Walter \& Co. de 21 de abril de 1915. 
Londres fornecesse ao menos uma linha de crédito permanente para o Banco do Brasil com aval do Banco da Inglaterra. Isto eliminaria a necessidade de avais de outros bancos e agilizaria as transações comerciais. O governo brasileiro arrazoava que o país merecia atenção especial porque estava contribuindo com a defesa dos interesses do Reino Unido e de seus aliados ao patrulhar a imensa costa marítima do país com os poucos navios em condições de realizar estas manobras. Estes navios poderiam estar exercendo funções comerciais. O Brasil estava perdendo recursos. ${ }^{275}$

O Ministério da Fazenda dizia que medidas simples como o atendimento da solicitação de crédito para o Banco do Brasil poderiam garantir muitos bons negócios às empresas britânicas que teriam a possibilidade de ocupar o espaço deixado no mercado brasileiro por produtos que antes eram importados dos países que hoje estavam bloqueados pela guerra, especialmente de fornecedores do Império Alemão e do Império Austríaco. O Banco do Brasil poderia facilitar esta assunção dos negócios dos países em litígio porque o banco contava com elevado grau de centralização da burocracia no comércio exterior brasileiro e tinha a palavra final nos processos de importação neste contexto de restrição de moeda conversível. ${ }^{276}$

A solicitação de crédito para o Banco do Brasil poderia ter sido apenas mais uma na profusão de negócios de vários países que o governo britânico analisava simultaneamente, mas o caso ganhou importância porque o Departamento de Comércio da Guerra não via a questão apenas do ponto de vista dos negócios no curto prazo, mas sim pela forma como o Brasil mantinha a neutralidade ligada à Entente. ${ }^{277}$ Esta ligação entre o Brasil e os países aliados era fruto das relações que o Brasil desenvolveu ao longo de muitos anos com o Reino Unido. Foram relações essencialmente financeiras que tiveram como interlocutores as casas bancárias Schröder e Rothschild. Os meandros da atuação destas duas instituições financeiras britânicas no Brasil durante a guerra é o foco do próximo capítulo.

Conclusão

A ascensão do Banco do Brasil no comando da economia brasileira permitiu à instituição entrar em contato direto com os credores internacionais que eram donos da dívida externa brasileira. Estes contatos internacionais levaram o banco a estruturar modelos de

${ }^{275}$ Brazilian Finance, T 1/11865/10907 maio 1915, carta de Jacob Walter \& Co de 29 março 1915.

${ }^{276}$ Ibidem.

${ }^{277}$ Memorandum respecting a proposed credit for Brazil, 05 julho 1915, T1/11865/16120. 
negócios que permitiram ao Brasil, de maneira inusitada, fechar contratos que tinham o café como garantia. Nestas operações, o Brasil acabou conseguindo ultrapassar as barreiras que a guerra havia colocado ao comércio exterior do Brasil. A consequência foi ter colocado café estocado no exterior em quantidade que acabou afetando o preço do produto no mercado internacional.

Além do café, o Banco do Brasil tentou entrar no mercado da borracha. O banco tinha a intenção de fazer com este mercado o que o Brasil havia conseguido com o mercado de café: o controle dos preços por meio do controle da oferta. Estas tentativas não foram avante porque o preço da borracha no mercado internacional passou a depender da produção asiática. Os poucos momentos de aumento do preço para a variedade brasileira não permitiram a formação de um fundo que conseguisse impor condições no mercado internacional.

Os contatos que o Banco do Brasil empreendeu no exterior durante a guerra, transformaram a instituição em profunda conhecedora do comércio exterior brasileiro. Esta posição no setor externo do Brasil foi sedimentada e transformou o banco no maior interlocutor do governo com exportadores e importadores após a guerra. Para ampliar as exportações brasileiras, o Banco do Brasil tentou viabilizar a instalação de estrutura logística do país, induzindo negócios no setor ferroviário. Esta logística permitiria que o Brasil resolvesse parte da carência de combustíveis que o país enfrentou durante a guerra. Isto seria possível com o acesso ao carvão do Sul do país.

A nova posição que o Banco do Brasil passou a ocupar na economia brasileira durante a guerra levou a instituição a propor a criação de um banco central no país. A ideai era que o próprio Banco do Brasil se encarregasse das funções típicas de controle de moeda, inflação e câmbio. Para tanto, o banco deveria voltar a emitir moeda. As discussões no governo e no Congresso não permitiram levar esta ideia adiante.

Os contatos que o Banco do Brasil realizou no mercado financeiro internacional permitiram que a instituição incorporasse métodos de ação internacional que eram utilizados pelos principais agentes da dívida externa brasileira, as casas bancárias Rothschild e Schröder. A forma como estes bancos agiram em nome do Brasil e os impactos que suas ações tiveram para a economia brasileira são o tema do próximo capítulo. 


\section{Capítulo 7 - Intermediação bancária internacional: Rothschild e Schröder}

A casa bancária N.M. Rothschild era o principal agente do governo britânico desde as Guerras Napoleônicas. Esta forte ligação com o poder no Reino Unido, permitiu ao Rothschild se estabelecer como responsável pela administração da dívida externa brasileira, a pedido do governo britânico. A proximidade do banco britânico com o governo brasileiro se estreitou até o começo da guerra. O Rothschild fazia papel duplo: levava interesses do Brasil ao Reino Unido e trazia demandas britânicas para o Brasil.

O longo processo de assinatura do funding loan teve grande participação do Rothschild. Na verdade, o contrato, da forma como foi assinado, traz inúmeras cláusulas que foram discutidas e estabelecidas pelos banqueiros britânicos. Esta operação de empréstimo consolidado para o Brasil durante a guerra foi interpretada pelos banqueiros Rothschild como uma vitória exemplar porque banqueiros internacionais de vários países concordaram em liberar novos recursos ao Brasil em um momento de contingenciamento.

A casa bancária Schröder tinha um modo de atuação mais inovador nos negócios internacionais. Os banqueiros Schröder se consolidaram como os principais agentes do governo de São Paulo no exterior. Como o estado era o maior produtor nacional de café, a influência do banco junto ao governo brasileiro era elevada. Coube aos Schröder negociar café brasileiro em situações atípicas. Estas negociações aumentaram o estoque de café paulista no exterior, o que prejudicou a cotação do produto. A grande quantidade de café que o Brasil foi obrigado a manter durante a guerra na Alemanha havia sido negociada pelo banco Schröder. 
Seção 7.1 - A dependência da economia brasileira das casas bancárias Rothschild e Schröder.

A partir de 1825, o Rothschild passou a atuar no Brasil na intermediação de contratos de transporte marítimo, seguros e atividades bancárias para empresas baseadas no Brasil ou que tinham negócios com o país, operações que foram executadas com letras de câmbio, dinheiro em espécie ou ouro como forma de pagamento. Estas transações mercantis do Rothschild contaram regularmente com a participação dos agentes financeiros Samuel, Phillips \& Co e Leuzinger \& Co estabelecidos no Rio de Janeiro e que também auxiliaram o Rothschild na intermediação da maior parte dos empréstimos negociados pelo governo brasileiro com o Reino Unido entre 1852 e 1918. Esta situação de destaque no mercado financeiro nacional proporcionou aos banqueiros britânicos alto grau de influência na política econômica brasileira em suas diversas facetas durante este período. O poder do Rothschild se consubstanciou com o vulto dos empréstimos realizados que entre 1855 e 1914 totalizaram $£$ 173 milhões, sendo $£ 37$ milhões destinados à expansão da malha ferroviária, dos quais $£ 16,6$ milhões serviram para a nacionalização de parte do sistema. ${ }^{278}$ Para noção da escala destes valores, a dívida externa brasileira em 1913 atingiu $£$ 91.785.037, composta em grande parte de empréstimos para portos e ferrovias que tiveram a chancela do Rothschild. ${ }^{279}$

Um grande problema para o Rothschild foi não ter conseguido impedir que as Províncias do Brasil - Estados, a partir da Proclamação da República - utilizassem o sistema financeiro internacional por meio da intermediação de outras casas bancárias que foram atraídas pelo retorno financeiro que o Rothschild obtinha com os processos de financiamento público brasileiro. As operações financeiras internacionais dos Estados foram porta de entrada para a concorrência e a partir do final do século XIX o mercado da dívida externa nacional passou a contar com a participação dos banqueiros da casa Schröder que ganharam projeção nacional com base em negócios realizados a mando do Estado de São Paulo.

Durante a guerra, o nome de maior referência para o Brasil nas negociações com os banqueiros internacionais era o de Alfred Rothschild, que em 1915 contava com 72 anos quando concedeu entrevista ao $O$ Estado de S. Paulo sobre o setor externo da economia brasileira. O banqueiro que tinha personalidade reclusa e saúde abalada - viria a falecer no início de 1918 - concordou em emitir algumas observações sobre a situação da economia

\footnotetext{
${ }^{278}$ Rothschilds and Brazil: An Introduction to Sources in the Rothchild Archive. Rothschild Archive.

${ }^{279}$ Brazil - Annual Report, 1913 - External Debt of Brazil, 15 janeiro 1915, FO 371/1915/5814, p.14.
} 
internacional para o Brasil durante a guerra. Como herdeiro do Rothschild, ele começou por comentar que estava sendo muito complicado financiar o Brasil durante a guerra porque a demanda por capital na Europa crescia vertiginosamente, e como o Brasil já em 1915 - muito pouco tempo após a operação do funding - estava necessitando de outro empréstimo, o conselho do banqueiro foi para que o país economizasse como nunca porque a escassez de recursos durante a guerra tendia piorar ao final do conflito por conta da demanda por capital que sobreviria para a reconstrução das nações beligerantes. $O$ banqueiro acreditava que a economia brasileira estava em uma fase de relação excelente com o sistema financeiro internacional. A consolidação da dívida permitira ao país um perdão de três anos para o pagamento dos serviços e da amortização do passivo com o exterior, uma situação invejável. Em comparação, Rothschild disse que quase todos os países estavam passando por uma grave crise de falta de ouro e o Brasil tinha acabado de receber $£ 15$ milhões com a prerrogativa de contar com três anos para reestruturar o sistema financeiro interno durante a guerra. Situação única em um mundo em guerra total, avaliou Alfred Rothschild.

O que o banqueiro não compreendia era como o governo brasileiro já cogitava solicitar novo empréstimo apenas alguns meses após a assinatura em Londres do complexo contrato de repactuação da dívida. Na opinião do Barão Rothschild, os responsáveis pela economia brasileira deveriam ver as coisas por um prisma mais amplo e aproveitar as chances excepcionais que a economia internacional estava proporcionando ao país. Como exemplo da falta de visão da elite brasileira, ele mencionou que chegou ao conhecimento do Conselho Diretor do Rothschild a grande frustração ocorrida no comércio interno do Brasil, incluindo os bancos, que interpretaram como um fracasso a postergação da assinatura do funding para o final de 1914. Este sentimento não foi compreendido pelos sócios do Rothschild que concluíram que o melhor havia ocorrido para as finanças do Brasil porque o país ficara livre de ver despencar o valor dos seus títulos no mercado internacional em um contexto de eclosão da guerra. Teria sido um trabalho infrutífero e despropositado apressar uma operação tão imbricada apenas por questão de um par de meses. Fica evidente nas palavras do representante maior dos Rothschild que eles trabalharam, mesmo que de maneira tácita, para a postergação da assinatura do contrato. O problema é que esta estratégia não foi assimilada pelo governo brasileiro.

Alfred Rothschild avaliou que as negociações para o funding na forma como foram conduzidas pelo Rothschild procuraram deixar uma imagem positiva para o Brasil, um recado 
para os credores europeus dos mais variados matizes, incluindo comerciantes, banqueiros e industriais, que o país estava buscando o melhor caminho para o equilíbrio de longo prazo da macroeconomia e que os negócios brasileiros passariam a ter bases mais sólidas. O Rothschild acreditava que tudo isto havia sido alcançado e que a missão foi cumprida: o funding poderia entrar para a história como um excelente acordo para todos os envolvidos, menos ao grupo formado pelos credores arrolados no empréstimo de 1911 - os financiadores das ferrovias e do Porto do Rio de Janeiro - que solicitaram juros mais elevados durante as negociações, mas acabaram cedendo por persuasão do Rothschild, corrigiram os entrevistadores. Ao final da entrevista, foi sondado com Alfred Rothschild se ele apoiaria um novo plano de valorização do café, ideia que estava em voga nos círculos do poder em São Paulo. ${ }^{280}$ Como previsível, a reação foi negativa porque os Rothschilds eram contra qualquer especulação econômica pelo Estado que visasse o estabelecimento de um nível mínimo para o preço de qualquer produto, fosse qual fosse. Devido a esta posição contrária de Rothschild, as tentativas de cartelização da economia cafeeira passaram a ser abordadas junto ao Schröder que utilizou a conquista da conta dos negócios internacionais do Brasil como um dos pontos do seu plano de expansão global.

O conflito mundial significou importante alteração na lógica geral de atuação do Rothschild na ponte que eles executavam entre o Brasil e as constantes necessidades do país de recursos em ouro. Os banqueiros britânicos geralmente viam o país como uma boa oportunidade de lucro elevado o que compensava o alto risco que os contratos com o setor público e com o setor privado embutiam. O problema que a guerra trouxe foi que o governo britânico, naquele período, estava na posição de travar concessões de crédito que não tivessem relação direta com o conflito mundial, e isto incluía proibir transferências de recursos para o balanço de pagamentos do Brasil. Este era um recado direto para o Rothschild que teve que modificar o conteúdo das interpelações junto às autoridades britânicas e passou à tática de mostrar as possibilidades de lucro no comércio com o Brasil no pós-guerra, possibilidades que poderiam perfeitamente cair nas mãos de empresas norte-americanas caso Londres não demonstrasse consideração com o grave momento das finanças brasileiras.

As ameaças vindas dos Estados Unidos não eram, na opinião do Departamento de Comércio da Guerra do Reino Unido, mais importantes que a manutenção da própria

\footnotetext{
280 'Em face dos nossos banqueiros - Entrevista dos Srs. Rothschild e Schröder ao Sr. Albuquerque de Medeiros, Londres janeiro de 1915', O Estado de S. Paulo, 12 janeiro 1915, p. 4.
} 
estabilidade financeira do país. Em tempos atípicos como aqueles, o melhor a ser feito era mesmo ouvir o Brasil e acenar com soluções paliativas. A situação exigia que todo o ouro disponível fosse entesourado como forma de driblar os graves problemas que os britânicos tinham em casa. Nas palavras do representante do governo britânico o que deveria ser feito era 'keep breath to cool our own porridge' [ 'guardar forças para enfrentar os nossos próprios problemas']. Se os entendimentos entre o Brasil e os Estados Unidos estavam avançando durante a guerra com perspectivas de mais negócios após o armistício, o que o governo britânico deveria fazer era correr os riscos. O importante naquele momento era mesmo garantir bases sólidas para o mercado doméstico do Reino Unido. ${ }^{281}$

$\mathrm{Na}$ hierarquia do relacionamento do Brasil com o mercado financeiro internacional, o Barão Schröder era o comandante da instituição bancária que o estado de São Paulo utilizava com maior assiduidade nas questões do comércio do café. Ajudava em muito o fato de que o Barão era grande produtor de café no estado, proprietário de fazendas importantes. No entanto, no início de 1915 Schröder não acreditava que uma operação de valorização do produto como a que havia sido proposta pelo senado brasileiro fosse indicada porque os preços estavam em boa fase e ele não acreditava que o Brasil estivesse impedido por completo de fazer chegar à Europa e principalmente aos Estados Unidos a maior parte da produção de café.

Quando perguntado na entrevista ao $O$ Estado de $S$. Paulo sobre o mecanismo em voga na política econômica brasileira de emitir papel para a compra de estoques de café, o banqueiro mostrou-se absolutamente contra porque achava que se tratava de uma típica política de falsificação de dinheiro. A única vantagem desta criatividade financeira era que o grande fiador, a base da transação, era o estado de São Paulo, único local do mundo naquela altura dos acontecimentos com liquidez endossável por qualquer banqueiro estrangeiro. Se um novo empréstimo ao Brasil se fizesse necessário, bastava que fosse o café paulista arrolado como garantia e os banqueiros europeus se interessariam em estudar o caso, garantiu o Barão Schröder. $^{282}$

O receio da participação de maneira mais intensa de banqueiros norte-americanos no Brasil com o propósito de atender demanda do governo por novos recursos em ouro

${ }^{281}$ Export of coffee from Brazil and Brazilian Finance, setembro 1916, FO 371/2640/183580, carta de Mr. Barstow, 22 setembro 1916.

${ }^{282}$ Entrevista "Em face de nossos banqueiros", Op. cit. 
movimentou a diplomacia britânica e envolveu diretamente o Schröder. O estado de São Paulo tinha dívidas em atraso com banqueiros de Londres, valores não contemplados no funding loan porque a consolidação da dívida que se executou em 1914 foi de origem federal. O valor que o estado de São Paulo pleiteava era de $£$ 3,5 milhões e como as portas para novos empréstimos estavam fechadas na Europa, emissários financeiros do governo Paulista foram buscar a solução em Nova York. A Divisão de Comércio Exterior do governo britânico emitiu alertas específicos sobre o caso porque identificou na possibilidade de esta operação se concretizar uma perda importante para os bancos britânicos, ainda mais em um momento de restrição de negócios financeiros. A solução que parecia adequada naquele momento era o estabelecimento do British Trade Bank que poderia tomar o lugar do Schröder como representante das finanças de São Paulo e obter empréstimos em Nova York utilizando o café paulista como garantia colateral. Característica interessante do sistema financeiro britânico nesta passagem foi que os bancos não discutiram entre eles as operações de empréstimo internacional para São Paulo: o Schröder não tinha ciência que era o banco Rothschild, a pedido do Tesouro Britânico, que estava negociando a compra de café do paulista como forma de liberar recursos em ouro para o Brasil. ${ }^{283}$

\section{Seção 7.2 - Diversificação de negócios financeiros}

Não era somente o café de São Paulo que chamava a atenção dos banqueiros internacionais. No final de 1916, um consórcio de quatro bancos de Nova York ofertou títulos no mercado norte-americano para um empréstimo de $£ 5,5$ milhões para a Cidade de São Paulo. Com títulos vencendo entre 1919 e 1928, este foi o primeiro empréstimo de banqueiros norte-americanos para um município da América do Sul. Os títulos foram emitidos com autorização do estado de São Paulo e tinham como garantias as receitas dos impostos de serviços sanitários, de profissões e do imposto industrial cobradas pela Cidade de São Paulo. O empréstimo foi concedido por William M. Imbrie \& Company, Equitable Trust Company of New York, E.E. Rollins \& Sons and Spencer e Trask \& Company. As perspectivas e riscos das operações de empréstimo ao estado e à cidade de São Paulo eram analisados sem a aparente ciência do Schröder porque o Tesouro Britânico tinha receio que se o banco soubesse de todo este interesse nos seus negócios, o preço para repassar os papéis e garantias seria

\footnotetext{
${ }^{283}$ Finance of the State of São Paulo, dezembro 1916, FO 371/2640/251784, p. 301.
} 
majorado e a blindagem para os banqueiros de Nova York da operação de financiamento em São Paulo dificultada. ${ }^{284}$

Caso também representativo da relação do Brasil com o sistema financeiro internacional foi o protagonizado por Lord Churston III, representante oficial de banqueiros de Nova York em Londres. Lord Churston II recebeu em meados de 1916 do estado de São Paulo um lote de títulos de dívida estadual não securitizada. O negócio foi para análise de banqueiros norte-americanos que recusaram participar do processo a menos que o agente fiscal do estado de São Paulo fosse o banqueiro W.A. Reads. Esta imposição poderia ser resolvida pelo Schröder dada a proximidade que os banqueiros tinham com o governo do estado de São Paulo. ${ }^{285}$

Se um grupo de banqueiros de Nova York fosse formado para adiantar $£ 5$ milhões para o pagamento de garantias de uma operação do estado de São Paulo de 1914, o Schröder poderia constituir uma agência fiscal em Nova York para cuidar do assunto. Lord Churston III acreditava que as negociações, apesar de adiantadas, não deveriam continuar sem um parecer com deliberação expressa do Tesouro Britânico. Como o Schröder era o agente físcal do estado de São Paulo, nada poderia ser feito sem uma análise do fluxo de recursos administrados pelo Schröder, que tinha a primazia de coletar semanalmente a taxa cobrada nas operações com café, conforme Figura 7.1.

Se a transação envolvesse os banqueiros de Nova York, metade dos recursos teria que ser transferida na forma de depósitos para o agente fiscal nos Estados Unidos, significando que o Schröder não mais teria acesso ao total de $£ 1.083 .600$ previamente acordado. A questão discutida entre os banqueiros britânicos era se a vantagem maior residia em ser remunerado por serviços prestados ou seria continuar tendo a possibilidade de administrar o recurso total. O receio era que a abertura deste tipo de operação para outras praças financeiras - como Nova York e Paris - embutia o risco da perda de controle sobre um importante negócio mundial e sobre o qual apenas os britânicos até aquele momento tinham controle. Se o British Trade Bank fosse estabelecido no Brasil, seria possível remunerar o Schröder, obter a agência fiscal e ainda incluir os títulos negociados no Brasil como garantia colateral para os empréstimos britânicos em Nova York. Para coroar a operação com brilho, seria mantida a posição privilegiada que o Reino Unido tinha no Brasil, mercado no qual um empréstimo de $£$

\footnotetext{
${ }^{284}$ Finance of the State of São Paulo, dezembro 1916, FO 371/2640/255372, p. 310-1..

${ }^{285}$ Finance of the State of São Paulo, dezembro 1916, FO 371/2640/251784.
} 
3,5 milhões era mais vantajoso que o controle da arrecadação da taxa sobre as negociações do café no mercado internacional. ${ }^{286}$

O governo britânico estava disposto a patrocinar a mudança do método de ação dos bancos britânicos no Brasil para não perder a possibilidade de lucro com juros e resgates precisamente das operações geradas pelo governo de São Paulo. No quadro da dívida externa de São Paulo exibido na Figura 7.1, notam-se as muitas possibilidades de negócios nas quais o Schröder esteve envolvido e, consequentemente, como a perda destas operações seria prejudicial aos interesses do Tesouro Britânico. Mais rentável era aplicar o capital na securitização destes empréstimos e receber o serviço correspondente da dívida do que obter concessão de ferrovia como a Sorocabana, uma das mais rentáveis em operação no Brasil durante a guerra. ${ }^{287}$

Figura 7.1 - Quadro-resumo da dívida externa do estado de São Paulo (libras esterlinas)

\begin{tabular}{ll}
\hline (A) Empréstimos garantidos & $£$ \\
$5 \%-$ Títulos do Tesouro 1913 & 5.716 .000 \\
Total de emissões de bancos alemães & 800.000 \\
$5 \%-2$ anos Notas do Tesouro 1914 & 2.940 .000 \\
& 7.856 .000
\end{tabular}

Garantia de sobretaxa de 5 fcs (francos)/saca de café exportado na proporção de $2,5 \mathrm{fcs} / \mathrm{cada}$

Em 1915 a sobretaxa totalizou:

Títulos hipotecados de 1913

Notas hipotecadas de 2 anos

Total (2)

Estes empréstimos foram garantidos com café e as receitas das vendas de café ocorreram primeiro sobre o empréstimo de 1913 e, na sequência, sobre as Notas do Tesouro.

(1) Valor de 1.183.189 sacas de café estocadas nos portos de Havre e

\footnotetext{
${ }^{286}$ Ibidem.

${ }^{287}$ Ibidem.
} 
Marselha

no total de (câmbio de 25,20)

(2) Receitas de vendas de 1.832.530 de sacas de café estocadas nos portos de

Hamburgo, Antuérpia e Trieste no total de (câmbio de 20,40)

Total (3)

9.264 .622

Dresdner Bank Berlin - 1905

Société Générale \& Banque de Paris - 1907

Total (4)

Total A $(1+2+3+4)$

(B) Empréstimos sem garantia

British Bank of South America (1888)

Província de São Paulo 5\% (1888)

London \& Brazilian Bank Ltd (1904)

Notas do Tesouro - 1 ano

Total (5)

Total B (5)

Total Geral $(\mathrm{A}+\mathrm{B})$

Fonte: Finance of the State of São Paulo, dezembro 1916, FO 371/2640/251784, p.302-3.

A profusão de operações de crédito envolvendo o estado de São Paulo não foi maior porque a União conseguia fechar contratos com mais facilidade, dada a possibilidade de utilização das receitas do porto do Rio de Janeiro - as maiores do Brasil durante a guerra como garantia. Contudo, é notável verificar como o café tipo Santos atraiu interesse de casas bancárias de diversas praças europeias e ainda como os valores envolvidos nos contratos internacionais que envolviam o estado de São Paulo eram elevados quando em comparação com a dívida contraída pelo governo brasileiro. O segundo funding loan marco na história econômica nacional, totalizou $£ 15$ milhões, apenas um pouco mais da metade dos valores arrolados nas transações paulistas. 
Acima da questão financeira imediata, além das especulações se os banqueiros britânicos ou norte-americanos ficariam com os volumosos recursos da administração da dívida de São Paulo, pairava dentro da chancelaria britânica uma preocupação distinta, esta de ordem estratégica típica da guerra. Como evidenciado na Figura 7.1, a dívida de São Paulo com banqueiros alemães era muito elevada, perto de $£$ 3,5 milhões, circunstância que quando considerada em conjunto com os estoques de café brasileiro em Hamburgo deixava o governo brasileiro dependente em última instância da forma pela qual o Departamento de Finanças do Império Alemão poderia influenciar na condução de transações que envolviam capital alemão como credor e devedor. ${ }^{288}$

O risco de o café brasileiro estocado na Alemanha servir como pagamento para parte do empréstimo com o Dresdner Bank, conforme relacionado na Figura 7.1, era tangível demais para o governo brasileiro. Por este motivo, o governo não se posicionava com clareza quando pressionado pelo Reino Unido sobre ações efetivas para proteger o litoral brasileiro de navios inimigos. Clareza e objetividade que também faltavam em relação à retenção de navios alemães em portos brasileiros. A solução ponderada no Gabinete de Guerra em Londres era usar a força adquirida pelo Rothschild junto ao governo brasileiro para induzir o Brasil a trocar o estoque de café por um novo crédito. Seria um contrato com cláusula pétrea sobre as garantias de mobilização da Marinha do Brasil contra navios alemães no litoral do país. ${ }^{289}$

Apesar da proximidade comercial entre o Império Alemão e o Brasil, a diplomacia britânica assegurava ao governo em documentos classificados como 'most secret' que a preferência das autoridades brasileiras seria sempre por fechar acordos de empréstimos com os bancos da Grã-Bretanha. Esta segurança vinha da longa relação financeira com o banco Schröder e principalmente com o banco Rothschild que eram os guardiões dos interesses do governo britânico junto ao Palácio do Catete e também os responsáveis por fazer o Brasil seguir os rumos ditados por Londres em matéria de política econômica e relações exteriores. Em relação aos problemas financeiros do Brasil, as instruções da diplomacia britânica repercutiam as decisões tomadas no Departamento de Comércio da Guerra e no Ministério da Guerra do Reino Unido que decidiram que Henry Lynch, representante do Rothschild, entrasse em contato com o governo de São Paulo e deixasse claro que o governo britânico

\footnotetext{
${ }^{288}$ Finance of the State of São Paulo, dezembro 1916, FO 371/2640/251784, carta de Victor Wellesley (FO) de 30 dezembro 1916.

${ }^{289}$ Ibidem.
} 
tinha ciência que a Alemanha estava em posse de grande soma de recursos pertencentes ao Brasil. $^{290}$

As instruções eram amplas e exigiam que o governo brasileiro se apossasse dos navios alemães e austríacos como garantia do pagamento destes recursos e usasse as embarcações para o comércio exterior do estado paulista. Os fretes internacionais relacionados a estes negócios deveriam ser contabilizados para acerto de contas após o término da guerra entre todas as nações envolvidas e a tripulação dos navios deveria ser originada exclusivamente de países neutros. Em paralelo, de maneira secreta, seria firmado um acordo entre o governo britânico e o governo brasileiro para a concessão de um empréstimo para a compra de café que deveria ter as sacas transportadas para a Europa nos navios apreendidos pelo Brasil. O custo dos navios que porventura fossem atacados nas rotas das exportações do café deveria ser contabilizado para cobrança junto aos Países Centrais, nas negociações do pós-guerra.

Ponto curioso nas negociações que envolveram a utilização de navios dos países inimigos durante os conflitos foi o de sempre colocar uma cláusula na cessão das naves ao país neutro para que este registrasse todas as operações de transporte de tal modo que os donos dos navios fossem ressarcidos após o fim do conflito. A guerra contra os Impérios Centrais não poderia ser considerada como motivo de força maior que justificasse o puro e simples arresto dos navios, como se pode deduzir dos documentos secretos do governo britânico. $\mathrm{O}$ respeito aos contratos de posse e de pagamento de aluguel pelo uso deveria ser mantido, apesar de os proprietários originais destes navios nunca terem dado aval para estas operações. $^{291}$

Para ajudar no pagamento dos arrendamentos forçados, os países aliados estariam dispostos a pagar fretes com pequeno desconto nos preços normalmente cobrados no mercado fora do período de guerra, solução que permitiria o um preço final bastante elevado aos proprietários dos navios. Diante das condições de guerra que impediam a transferência de valores entre os bancos de nações inimigas, os proprietários dos navios deveriam ser informados da contabilização dos valores que lhes cabia de tal maneira que fossem

\footnotetext{
${ }^{290}$ Henry Lynch (1878-1958) foi representante do Rothschild no Brasil durante grande parte da primeira metade do século XX. Era considerado nos meios diplomáticos o verdadeiro embaixador britânico no Brasil. As tradicionais origens anglo-brasileiras de Lynch tiveram muito peso nos relacionamentos com o alto poder que ele estabeleceu nos dois países. Ver: Business during the war, The Rothschild Archive.

${ }^{291}$ Brazilian Coffee - Decypher telegram received from Mr. Lynch, 23 dezembro 1916, FO 371/2640/252290.
} 
viabilizadas operações de crédito para estas empresas que poderiam oferecer como garantia os fretes contabilizados nas operações dos países da Entente. ${ }^{292}$

O curso dos eventos levou Henry Lynch a escrever ao Rothschild relatando que o melhor a fazer seria que a proposta do acordo para a compra do café e do empréstimo partisse do governo do estado de São Paulo, pois isto evitaria que os valores envolvidos na transação fossem inflacionados. O que ainda não estava certo era o que o governo brasileiro faria em relação aos navios germânicos porque o valor devido pelo Império Alemão ao Brasil em cálculo revisto totalizava $£ 6$ milhões, valor muito elevado e que desencorajava o presidente Wenceslau Braz a tomar medidas mais hostis em relação a Berlim. Lynch queria saber como o governo britânico queria que o governo brasileiro fosse instruído a agir e sugeriu que uma apreensão dos navios de maneira incondicional talvez fosse uma boa medida. Impor ao Brasil uma medida mais dura como esta poderia significar dificuldades para os negócios britânicos com empresas brasileiras e com o governo no curto prazo, mas seriam problemas transponíveis. $^{293}$

O Rothschild se tornou disposto a ouvir novas propostas de negócios e dada a forte relação que eles mantinham com as autoridades brasileiras foram acionados pela Delegação Britânica no Brasil para tentar encontrar uma solução ao pedido especial de Wenceslau Braz para que as exportações de café voltassem a ser liberadas sem restrições. O Presidente do Brasil indicou os motivos da solicitação que na interpretação brasileira fugiam às regras estritas deste período da guerra:

a) O café exportado não teria outro propósito que o de atender as demandas das forças armadas do Brasil que necessitavam de reaparelhamento para cumprir determinações militares definidas por Londres para os países neutros;

b) A classificação das exportações de café como contrabando causou consequências desastrosas na posição financeira de várias regiões produtoras brasileiras, impedindoas de cumprir com seus compromissos financeiros externos;

c) Os países aliados tinham muitos interesses econômicos no Brasil e a prosperidade do país deveria ser evocada quando das deliberações sobre solicitações de exceção do governo brasileiro.

\footnotetext{
292 Ibidem.

${ }^{293}$ Brazilian Coffee, dezembro 1916, FO 371/2640/252290, telegrama nr. 502 de Henry Lynch para Rothschild.
} 
Para o governo britânico esta demanda do governo brasileiro soou muito mais como um clamor que foi por eles resumido como tentativa desesperada do país em transformar papel moeda não conversível em ouro. Os objetivos de Wenceslau Braz eram mais amplos e envolviam o atendimento de requisição expressa e contundente dos empresários ligados à cafeicultura por caminhos alternativos que desovassem o café já estocado em Santos. Do lado do governo, a intenção percebida pelo Tesouro Britânico era sondar a possiblidade de manter o ouro correspondente às exportações em Londres como garantia para empréstimos futuros e também para atender pontos estabelecidos no contrato do funding loan de $1914 .^{294}$

O Rothschild, em parceria com o Ministério da Fazenda do Brasil, já havia levantado esta possibilidade de obtenção de ouro, o que lhes permitiria continuar na linha de frente da administração da dívida externa brasileira. Quando o Brasil precisasse de ouro para cobrir compromissos no exterior, duas frentes de ação seriam executadas, uma interna e outra externa. Internamente, o Ministério da Fazenda, mediante autorização especial do governo, emitiria moeda exclusiva e especificamente para a compra de sacas extraordinárias de café para exportação, remunerando os produtores locais. Estas sacas especiais de café seriam negociadas na Europa por intermédio dos agentes especiais do Brasil no exterior, com aval do Rothschild. Vendido o café objeto desta manobra, os recursos em ouro seriam depositados em Londres sob os cuidados do Rothschild. ${ }^{295}$

Como sempre ocorria em situações similares, os banqueiros do Rothschild foram acionados e Henry Lynch instruído a negociar com Wenceslau Braz de maneira dura e de tal forma que não fosse perdida a grande oportunidade de resolver as diversas pendências que o Reino Unido tinha com o Brasil, pendências das mais diversas bases e que estavam sem previsão de definição, como mostra a Figura 7.2 na qual estão relacionadas as correspondências entre os dois governos com datas, nomes dos responsáveis pelos assuntos e as demandas que o governo britânico esperava fossem atendidas. ${ }^{296}$

A maioria dos casos era de origem comercial e tratava de investigações de contrabando, mas também havia questões ligadas à segurança do corpo diplomático britânico e do julgamento de assassinos de cidadãos britânicos, assuntos sobre os quais o corpo diplomático era cobrado pelo Parlamento Britânico. Dentre a variedade de temas, os que

\footnotetext{
${ }^{294}$ Brazil, trade and treaty, 15 setembro 1916, FO 371/2640/183580.

295 Ibidem.

${ }^{296}$ Correspondence with Brazilian Government, setembro 1916, FO 371/2640/176934.
} 
maior empenho o Rothschild deveria ter eram os relacionados ao já antigo caso da Manaos Improvements Company, à expansão do telégrafo e, como ponto adicional de extrema urgência, às tarifas especiais recentemente oferecidas aos Estados Unidos. Esta última era uma possibilidade que o governo britânico classificava como ultrajante e que, se aprovada pelo Congresso Brasileiro, faria Londres exigir que as mesmas vantagens fossem estendidas aos produtos britânicos. 
Figura 7.2 - Quadro-resumo dos assuntos pendentes entre os governos do Brasil e do Reino Unido.

Listagem de assuntos sem resposta

1915

$$
\mathrm{Nr} \text {. }
$$

Ref. Destinatório Data Título

18 Dr. Lauro Müller (a) 23/abr Manaos Improvements Company

Dr. Lauro Müller (a) 23/abr South American Construction

Dr. Lauro Müller (a) 14/jun Manaos Improvements Company

21 Dr. Lauro Müller (a) 26/jun Western Telegraph Company

21 Dr. Lauro Müller (a) 10/jul S. S. "Gladstone"

23 Dr. Lauro Müller (a) 05/jul Entrada livre na alfândega

24 Dr. Lauro Müller (a) 05/ago Entrada livre na alfândega

27 Dr. Lauro Müller (a) 17/ago Convenções Radiotelegráficas

40 Dr. Lauro Müller (a) 30/nov Assassinato de Brown e Radley

42 Dr. Lauro Müller (a) 04/dez Obras no Porto do Rio de Janeiro

1916

1 Dr. Lauro Müller (a) 03/jan Contrabando - produtos do inimigo

4 Dr. Lauro Müller (a) 17/jan Santos Improvements Company

5 Dr. Lauro Müller (a) 22/jan Contrabando (borracha)

6 Dr. Lauro Müller (a) 31/jan Contrabando - produtos do inimigo

\section{Assunto}

Novas sugestões do Tesouro Britânico

Solicita liquidação para evitar apreensão

Pressiona por solução para a dificuldade relacionada

Solicita extensão do cabeamento até Assunção (Paraguai)

Investigação sobre venda para empresa dinamarquesa

Solicita livre entrada para o Vice-consulado

Solicita livre entrada para o Consulado de Pernambuco

Países em vias de adesão desde 01/maio

Solicita prisão de Torres

Solicitado ao ministro das Relações Exteriores que use influência para que uma solução ponderada

Informa sobre liberação de remessa da empresa Bordallo

Intervenção em favor da empresa

Borracha embarcada no S.S. Gelria por Araújo

Informa sobre dificuldades criadas pelos alemães- descarga 
Dr. Lauro Müller (a) 03/fev Contrabando - produtos do inimigo

24 Dr. Lauro Müller (a) 10/abr Negociando com o inimigo

34 Dr. Lauro Müller (a) 05/jun Navios Britânicos e Navios Aliados

36 Dr. Lauro Müller (a) 05/jun Caso "Poynter Macdonald"

40 Dr. Lauro Müller (a) 16/mai Bagagem para os cônsules

41 Dr.Souza Dantas (c) 23/jun Explosão Tennyson

Adendos ao documento original:

(a) Ministro das Relações Exteriores

(b) Provável referência a Godofredo Xavier da Cunha - Ministro do Supremo Tribunal Federal

(c) Ministro das Relações Exteriores
Não há informações sobre mercadorias- portos

Lista de adesões

Solicita informações sobre medidas tomadas contra Araújo

Governo britânico fornecerá garantias no lugar do depósito Pressiona solução - extensão do cabeamento até Paraguai

Solicita aceite das credenciais do Sr. Kennard

Explica ação do governo britânico referente a empresas neutras

Comunica incidente do S.S. "Morgan Abbey"

Pendência comercial

Solicita explicação medidas tomadas alfândega- Pará

Pergunta que ações serão tomadas

Fonte: Correspondence with Brazilian Government, setembro 1916, FO 371/2640/176934, p.144. 
Wenceslau Braz estava ciente das enormes dificuldades que teria para solucionar de pronto todas estas pendências de matizes tão distintos, mas que eram requisitos para a liberação das exportações de café. Dada a impossibilidade em atender o governo britânico, o Ministério da Fazenda elaborou plano alternativo que previa autorização para a venda de café para a Holanda e para países escandinavos no total de 1.000.000 de sacas até o final de dezembro de 1916. Sabendo que o governo brasileiro não teria condições de resolver os casos listados no curto prazo, Londres instruiu Henry Lynch no sentido de que em caso de autorização de exportação de café, os recursos correspondentes deveriam ficar na guarda do Tesouro Britânico. A preferência era evitar que o café fosse para outros destinos fora do controle do Departamento de Comércio da Guerra, mesmo que o produto vendido tivesse que permanecer em Santos como parte de estratégia de venda no pós-guerra. ${ }^{297}$

Lynch não deveria perder a oportunidade de pressionar o Presidente do Brasil para que fosse atendida a demanda sobre a equiparação das taxas de importação às dos Estados Unidos. Se isto ocorresse, as negociações poderiam continuar, mas o governo britânico entendia que as chances eram remotas porque Wenceslau Braz parecia ser um presidente tímido, sem condições de se impor e de exigir alterações desta ordem junto ao Congresso. Do ponto de vista da diplomacia internacional em geral, quem governava o Brasil na prática eram os interesses da economia cafeeira que se utilizava do Congresso para dar a seus interesses o necessário verniz de legalidade junto à sociedade. ${ }^{298}$

No desenrolar da guerra, mudanças nas relações entre o Brasil e a comunidade financeira internacional foram ocorrendo conforme os aliados percebiam que o tão esperado pós-guerra ainda demoraria. A entrada dos Estados Unidos no conflito se mostrara indispensável, mas ainda faltavam alguns eventos para que isto se tornasse realidade, como o torpedeamento de navios neutros norte-americanos por submarinos alemães e a saída do Império Russo da Tríplice Entente. ${ }^{299}$

No início de 1917 a cooptação de países neutros e com recursos primários passou a ser uma estratégia disseminada e o Rothschild foi acionado pelo governo britânico para participar do Brazilian Assistance Scheme (Programa de Assistência ao Brasil), plano

\footnotetext{
${ }^{297}$ Proposed purchase of brazilian coffee crop by HMG, setembro 1916, FO 371/2640 /193212.

${ }^{298}$ Ibidem.

${ }^{299}$ A entrada dos Estados Unidos na guerra ocorreu em 06 de abril de 1917 após a recusa do Império Alemão em cessar a guerra submarina e após o início da Revolução Russa, em fevereiro deste ano. As Forças Expedicionárias Americanas, sob o comando do general John Pershing, foram colocadas em várias linhas de batalha a partir de meados de 1918, especialmente em bloqueios aos portos da Alemanha. Ver: The Library of Congress - America's Library.
} 
audacioso e que pretendia envolver diversos aspectos de negócios com o Brasil que ajudasse a Entente a financiar os custos da guerra. Foi um dos maiores planos já pensados para o país cuja importância pode ser medida pela participação direta do Barão de Rothschild nas negociações.

Os muitos documentos assinados por Rothschilds durante todo o processo de análise da assistência ao Brasil, também tiveram a chancela de John Maynard Keynes que estava lotado no Tesouro Britânico. Keynes tinha como responsabilidade principal a administração do ouro e do crédito entre os aliados. Vários documentos desta e de outras operações financeiras que tiveram o Brasil como parte interessada passaram por Keynes. $\mathrm{O}$ economista exerceu autoridade máxima nestas operações de crédito a países estrangeiros, rejeitando ou dando continuidade aos processos de financiamento. ${ }^{300}$ A relação de Keynes com outros governos - solicitações de crédito partiam de várias países, principalmente colônias e ex-colônias britânicas - passou a ser rotineira. Conforme a participação direta dos Estados Unidos nos conflitos se aproximava, mais significativas passaram a ser as transações coordenadas por Keynes. Foram negociações que envolveram as mais altas instâncias do poder em Washington, como será abordado no capítulo 10.

O Programa de Assistência ao Brasil começou grandiloquente. As perspectivas eram boas para a economia brasileira poder enfrentar a crise que foi piorada com a proibição de exportação de café. Havia disposição do Tesouro Britânico em ajudar o país a superar os problemas não foram causados exclusivamente por motivos internos do Brasil. O Programa não foi um consenso dentro do governo britânico porque as exportações de café não estavam proibidas, apenas controladas. $\mathrm{Na}$ prática, o que estava ocorrendo naquele período era o fim do mercado de café como se conhecia antes da guerra. As restrições ao comércio aplicadas por meio da statutory list modificaram radicalmente o comércio internacional. No caso brasileiro, as mudanças significaram redução na entrada de ouro no país porque o café era considerado produto que poderia servir como reserva de valor. Esta característica tornava o produto alvo de contrabando e, por isto, controlado pela statutory list, assunto que será discutido na seção 10.1 .

Para começar a tratar da ajuda financeira do Programa de Assistência ao Brasil, a chancelaria britânica emitiu carta para os Rothschild na qual enumerou as condições que o

\footnotetext{
${ }^{300}$ Brazilian coffee export-Mess. Rothschild to prepare scheme for assisting, março 1917, T 1/12112/11162, carta do Barão de Rothschild para John Bradbury (Tesouro Britânico) e para John Maynard Keynes, 13 abril 1917.
} 
governo brasileiro deveria se comprometer em atender antes que o assunto fosse levado para análises mais detalhadas ao Departamento de Comércio da Guerra:

1) Na hipótese de que algum esquema de ajuda financeira fosse liberado para o Brasil, o governo britânico exigiria que o valor em questão fosse plenamente empregado no ressarcimento dos interesses de empresas britânicas credoras do Brasil, sem restrições quanto a alçada do poder federal;

2) Os fundos que porventura fossem liberados teriam destinação especificada por Londres;

3) Não seriam aceitas transações que visassem adquirir qualquer tipo de commodity no Brasil ou pertencente ao Brasil e que, porventura, estivesse alocada em outro país;

4) Estavam proibidos os pagamentos de juros a credores de qualquer país que não os domiciliados no Reino Unido;

5) O governo britânico não autorizaria estudos de propostas em qualquer escala superior a $£ 1$ milhão;

6) O governo brasileiro deveria arcar, nos meses restantes de 1917, com parte dos valores devidos aos investidores britânicos, especialmente dividendos, porque não ficaram comprovados os efeitos negativos na economia brasileira das restrições do Departamento de Comércio da Guerra às importações de café;

7) A operação preferencial do governo britânico era utilizar os recursos para a compra efetiva de café; como alternativa, admitia-se a possibilidade de o governo brasileiro utilizar café como seguro para empréstimos;

8) O Rothschild ficaria responsável pelas interlocuções nas solicitações de recursos, diretos ou indiretos, entre o governo brasileiro e o governo britânico.

Em documento separado, mas relacionado ao Programa de Assistência ao Brasil, Keynes abordou o assunto da liberação de recursos para o Brasil e instruiu a diplomacia britânica a aguardar novas considerações antes de autorizar o início das negociações, porque questões distintas ao problema financeiro estavam em estudo. ${ }^{301}$ Como mostra

\footnotetext{
${ }^{301}$ Treasury letters, março 1917, 1/12112/10965, carta-rascunho de John Maynard Keynes, sem data.
} 
documento endereçado ao Rothschild, estas questões eram distintas, mas relacionadas ao esquema de ajuda porque tinham como foco os portos brasileiros que o governo britânico ambicionava ver trabalhar em conjunto e a favor dos aliados durante a guerra. Estas tentativas de ligar assuntos financeiros às estratégias dentro da guerra foram ganhando impulso ao longo de 1917 e serviram como uma espécie de laboratório para ver como o Brasil agiria em um cenário de guerra, cenário no qual o país tivesse que assumir alguma posição estratégica efetiva. Os sinais dúbios emitidos pelo governo brasileiro ainda deixavam Londres sem a certeza que o país seria um aliado incondicional ou se tentaria continuar a levar relações amistosas com os as potências centrais até o final do conflito. Grande parte desta dúvida residia na intensa relação comercial que a economia cafeeira brasileira tinha com empresários alemães antes da guerra, relação esta que ultrapassava as operações de compra e venda porque dependia da infraestrutura de Hamburgo. ${ }^{302}$

Quando o assunto Programa de Assistência ao Brasil foi abordado pelo corpo diplomático britânico estabelecido no Rio de Janeiro com as autoridades brasileiras ficou claro que tantas exigências e condicionantes não configuravam o assunto que o governo brasileiro queria ver discutido de antemão. O que preocupava a equipe econômica de Wenceslau Braz era o valor que seria negociado, pois se para os padrões do Tesouro Britânico $£ 1$ milhão parecia algo de monta e que mobilizaria o país a envidar esforços para viabilizar o Programa de Assistência ao Brasil, para o Ministério da Fazenda este valor estava muito aquém das necessidades financeiras em ouro do país e não valeria o enorme esforço em continuar com as negociações. Na avaliação da representação britânica no Brasil, a soma em discussão era insuficiente para forçar o governo brasileiro a proceder com a liquidação das diversas pendências comerciais e financeiras com o capital britânico. Se o Programa de Assistência ao Brasil não poderia ter o valor majorado, restava colocar na mesa para discussão apenas e tão somente os casos das obras do fornecimento de água em Santos e os contratos Marconi de telégrafos, porque estes não envolviam o desembolso de dinheiro. O adido consular britânico no Brasil, Arthur Peel, aconselhou de maneira firme a chancelaria em Londres a não colocar os navios alemães como parte integrante das negociações, visto que a relação financeira entre o Brasil e o Império Alemão exigia muito

\footnotetext{
${ }^{302}$ Messrs. Rothschild, março 1917, 1/12112/10965, carta de John Maynard Keynes de 09 março 1917.
} 
mais cautela. Arriscar uma virada na política internacional brasileira em prol da Aliança era risco para ser evitado naquele momento delicado da geopolítica. ${ }^{303}$

Restava sempre voltar ao café e às possibilidades de barganha com o Brasil que o produto proporcionava. O grau de conhecimento que os diplomatas britânicos estabelecidos no Rio de Janeiro adquiriram da lógica do negócio do café permitia a eles emitir opiniões sobre o mercado futuro da commodity. Estas previsões direcionavam as decisões do governo britânico sobre a concessão ou não de crédito que envolvesse o café como garantia ou como mecanismo pelo qual o ouro era transferido ao Brasil e as sacas correspondentes de café repassadas à posse do Tesouro Britânico que poderia vendê-las quando achasse mais conveniente. Arthur Peel, no telegrama no qual abordou o Programa de Assistência ao Brasil, fez uma avaliação que ainda não tinha ocorrido ao Tesouro Britânico naquele contexto: a expectativa para a colheita de café na safra 1917/8 era de forte aumento na oferta, com muito mais sacas pressionando a baixa na cotação do produto. Além disto, os países que hoje eram considerados inimigos não estariam em condições de importar café após a guerra como o mercado especulava, uma vez que estas nações teriam que se preocupar com a taxa de câmbio e os termos de troca para a reconstrução em muitas frentes de infraestrutura. ${ }^{304}$ Não foi o que ocorreu. De acordo com os dados expostos na Tabela 7.1, o preço do produto subiu muito ao final da guerra, com grande margem de lucro para os agentes que estavam comprados em café.

Tabela 7.1 - Brasil, exportação de café, 19101920.

\begin{tabular}{r|lll|l|l|l}
\hline & Quantidade & Variação & Valor & Variação & $£$ / saca & Variação \\
1.000 sacas & $\%$ & $£$ mil & $\%$ & $\%$ \\
1910 & 9.724 & & 26.696 & & 2,75 & \\
1911 & 11.258 & $15,78 \%$ & 40.401 & $51,34 \%$ & 3,59 & $30,72 \%$ \\
1912 & 12.080 & $7,30 \%$ & 46.558 & $15,24 \%$ & 3,85 & $7,40 \%$ \\
1913 & 13.268 & $9,83 \%$ & 40.779 & $-12,41 \%$ & 3,07 & $-20,25 \%$ \\
1914 & 11.270 & $-15,06 \%$ & 27.000 & $-33,79 \%$ & 2,40 & $-22,05 \%$ \\
1915 & 17.061 & $51,38 \%$ & 32.191 & $19,23 \%$ & 1,89 & $-21,24 \%$ \\
1916 & 13.039 & $-23,57 \%$ & 29.281 & $-9,04 \%$ & 2,25 & $19,02 \%$ \\
1917 & 10.606 & $-18,66 \%$ & 23.054 & $-21,27 \%$ & 2,17 & $-3,20 \%$
\end{tabular}

\footnotetext{
${ }^{303}$ Brazil - Trade and treaty, março 1917, 1/12112/11162, telegrama de Arthur Peel datado de 31 março 1917. ${ }^{304}$ Ibidem.
} 


$\begin{array}{lllllll}1918 & 7.433 & -29,92 \% & 19.041 & -17,41 \% & 2,56 & 17,85 \% \\ 1919 & 12.963 & 74,40 \% & 66.081 & 247,05 \% & 5,10 & 99,00 \% \\ 1920 & 11.525 & -11,09 \% & 40.456 & -38,78 \% & 3,51 & -31,14 \%\end{array}$

Fonte: IBGE, Repertório Estatístico do Brasil - Quadros Retrospectivos $\mathrm{n}^{\mathrm{o}} 1$, p. 85 
O acompanhamento do plantio nos cafezais realmente permitia previsões de aumento considerável na oferta de café, não fosse a grande geada de junho de 1918 que eliminou milhões de pés da safra que chegaria ao mercado no último semestre da guerra. Como exposto na Tabela 7.1, somente em 1918 o preço da saca em libras foi de quase $20 \%$ acima do ano anterior e em 1919, mesmo com as exportações crescendo mais de $70 \%$ frente ao ano anterior, a saca de café teve o preço duplicado. Oportunidade de lucro fácil que o Tesouro Britânico perdeu e que poderia ter ajudado o governo britânico a enfrentar a escassez de recursos em Londres e reduzir, mesmo que marginalmente, a grande dependência dos repasses de Washington. O empréstimo ao Brasil que estava em análise acabou não sendo liberado por sugestão do Rothschild, que não identificou o momento como adequado para mais uma transferência de valores principalmente, porque via como baixa a possibilidade de o Brasil não continuar se submetendo às regras da Entente.

Aparentemente, as questões sobre o preço do café no mercado futuro e a indecisão do governo brasileiro em demonstrar posicionamento firme frente aos Impérios Centrais fizeram com que os envolvidos no Programa de Assistência ao Brasil recebessem com alívio a sugestão de Lionel Walter Rothschild, $2^{\circ}$ Barão de Rothschild. Vale notar que o valor em estudo era muito inferior aos recursos que o governo brasileiro se habituara a solicitar aos banqueiros internacionais antes da guerra e não deveria ter havido tanta mobilização em Londres por tão pouco, fato indicador de como a situação financeira do próprio Reino Unido piorou após agosto de 1914. Este longo caso do Programa de Assistência ao Brasil ajuda também a entender que a diplomacia britânica trabalhou arduamente durante a guerra para neutralizar a força econômica do Império Alemão com o intuito de recuperar posições na economia internacional. O mercado brasileiro era importante destino para empresas alemãs que ocupavam posição de destaque em negócios os mais diversificados. Além disso, e cidadãos de origem germânica se destacavam na política interna do país durante as hostilidades, tema do próximo capítulo.

\section{Conclusão}

A atuação no das casas bancárias Rothschild e Schröder alcançou ponto máximo no início da guerra. Com o desenrolar dos conflitos na Europa, os dois bancos foram perdendo 
força no Brasil. Os recursos do governo britânico ficaram escassos e esta escassez limitou a ação internacional dos banqueiros britânicos que não puderam mais participar de negócios sem autorização expressa do Banco da Inglaterra e do Tesouro Britânico. Estas limitações abriram espaço para a entrada no mercado brasileiro de banqueiros norteamericanos que estavam capitalizados e podiam oferecer negócios mais lucrativos ao Brasil. Mais do que lucratividade, o que preocupava o governo brasileiro era a possibilidade de obter acesso a novos mercados, a possibilidades de negócios que não se limitassem às regras estabelecidas pela Entente.

A força dos banqueiros dos Estados Unidos acabou levando o Schröder a firmar parcerias com bancos de Nova York para viabilizar a comercialização de café brasileiro. Esta parceria rendeu ao Brasil a possibilidade de repor parte da perda do mercado que a guerra tinha imposto ao país.

Negociações especiais levadas pelos banqueiros britânicos foram necessárias para resolver as pendências que travavam a posse do Brasil de navios alemães. Conseguida a transferência de ativos, os banqueiros trataram de obter contratos entre o Brasil e a França que alugou as embarcações alemãs para uso comercial na França. Foram contratos complexos, que exigiram acesso a dados considerados sigilosos pelos países envolvidos.

Durante a guerra, como a situação da economia brasileira passou a exigir mais recursos, o Rothschild voltou intermediar um plano de ajuda internacional ao Brasil. Não foi possível um plano nos moldes do funding loan, mas os banqueiros conseguiram firmar as bases do Programa de Assistência ao Brasil. Este programa somente foi possível porque o governo britânico identificou risco de o Brasil declarar apoio à Alemanha. Não era um risco infundado. As relações econômicas entre os dois países eram complexas e envolviam interesses em muitas áreas, como será visto no próximo capítulo. 


\section{Parte III - Negócios internacionais do Brasil durante a guerra}

\section{Capítulo 8 - Relações econômicas do Brasil com o Império Alemão}

As relações econômicas entre o Brasil e o Império Alemão se estreitaram a partir do final do século XIX quando a colonização alemã no Sul do Brasil atingiu números expressivos. O relacionamento entre os colonos e as suas regiões de origem ajudou os imigrantes a manter tradições e a acompanhar a evolução tecnológica que a Alemanha vivenciava.

O desempenho econômico da Alemanha era motivo de admiração no Brasil. O sucesso da Unificação Alemã tornou os feitos do país na área de tecnologia ainda mais conhecidos. As inovações que o capital alemão conseguia em diversas áreas faziam governantes de estados como Santa Catarina buscar acordos de cooperação com o Império Alemão. Foi precisamente em Santa Catarina que empresas locais se tornaram parceiras de empresas alemãs, o que aumento o grau de intercâmbio.

Em termos nacionais, a colonização atraiu a atenção de empreendedores alemães, principalmente para o negócio do café. O Brasil foi passando a depender mais das operações que estas empresas alemãs desenvolviam para o café brasileiro no exterior. Foi na virada do século XIX que Hamburgo se tonou o principal porto para o café brasileiro. O sucesso como café abriu oportunidades de negócios entre empresas brasileiras nas áreas de navegação e metalurgia.

Foi durante a guerra que as relações com o Império Alemão passaram a ser questionadas com maior incisão. A palavra pangermanismo ganhou força e dividiu a sociedade brasileira. A admiração passou a conviver com o receio. Temia-se que os interesses alemães fossem além de questões culturais, que parte do Brasil pudesse ser anexado pelo Império Alemão. 
O Brasil foi neutro durante a guerra, mas esta neutralidade era favorável aos países da Entente. O Reino Unido registrava os sinais de avanço do capital alemão no Brasil e passou aa alertar o governo brasileiro. Este monitoramento das atividades germânicas no Brasil colocaram em suspeita as ações de Lauro Müller. Müller foi ministro das Relações Exteriores do Brasil durante a maior parte da guerra. Ter um chanceler com ascendência germânica em posição tão importante incomodava os britânicos.

Após o rompimento das relações entre Estados Unidos e Alemanha, o Brasil passou a ser pressionado pelos norte-americanos para seguir o mesmo caminho. A dependência da economia brasileira do capital alemão dificultou a decisão de Wenceslau Braz de afastar o Brasil formalmente do Império Alemão.

Seção 8.1 - As raízes das relações econômicas com o capital alemão.

Quando a guerra começou na Europa, de pronto tiveram início especulações sobre o prazo para o término do conflito. Agentes econômicos nos principais centros de negócios acreditavam que seria um evento de forte impacto e de curta duração com base em interpretação equivocada da frase de Lord Kitchner - a mais famosa autoridade militar britânica e que maior destaque obtinha na imprensa mundial quando o assunto era a guerra. Em pronunciamento ao final de 1914, ele vaticinou: “Ou é uma guerra de três meses ou de três anos". 305 Apesar de mal interpretado em relação ao sentido correto da famosa frase, Lord Kitchner não estava preparado para previsões sobre o desenrolar dos eventos bélicos porque a capacidade de mobilização bélica da Alemanha era incógnita de decifração praticamente impossível. Especulava-se que a guerra tendia a demorar a ter um desenlace porque as empresas alemãs eram reconhecidas como de excelência em metalmecânica e o Vale do Ruhr era referência mundial em carvão coque e em aciaria. Era um conjunto de pontos positivos e fundamentais para abastecer uma guerra como a que se ensaiava e que acabaria por dar às

87 'O Brasil no exterior', O Estado de S. Paulo, 05 fevereiro 1916, p. 2;

Horatio Herbert Kitchner, Conde Kitchner, foi militar britânico de destaque durante os anos iniciais da PGM. Foi o responsável pela campanha de recrutamento voluntário que ficaria eternizada com a frase 'Britânicos: Lord Kitchner precisa de você. Junte-se ao exército do seu país! Deus salve o Rei' [Britons: Lord Kitchner wants you. Join your country's army! God save the King]. Faleceu a bordo de um navio em decorrência da explosão de uma mina lançada pelo submarino alemão U-75 em 05 junho 1916.

O conteúdo correto da frase dita por Lord Kitchner no Natal de 1914 preconizava que a guerra deveria durar de três a quatro anos e que toda a mobilização material e humana deveria ser colocada em prática para que a vitória fosse assegurada. http://www.historylearningsite.co.uk/LordKitchener.htm 
forças alemãs longo fôlego para as batalhas no Marne, no Sommes ou em Galípoli. Somente a partir de 1917, com a participação efetiva dos Estados Unidos, é que foi possível abreviar a guerra. O problema era que a entrada efetiva das forças americanas na guerra ainda necessitaria de mudanças na conjuntura internacional imprevisíveis em 1914.

As relações econômicas do Brasil com o Império Alemão ganharam vulto a partir do início do século XX e abrangeram as mais diversas áreas, mas o setor financeiro, a mineração, o comércio de máquinas e a questão da colonização germânica no Sul do Brasil foram os destaques na relação entre as duas nações. Antes da guerra, empresas alemãs interessadas no mercado brasileiro propunham negócios que pareciam irrecusáveis, como o que ocorreu quando o Sindicato da Siderurgia Alemão demonstrou interesse no minério de ferro de Itabira, Minas Gerais, e elaborou plano para a construção de estradas de ferro que permitissem escoar a produção por porto mais conveniente. ${ }^{306}$ Como este, diversos casos estampam registros de interesses do capital alemão no Brasil. Em julho de 1912 foi fundada em Berlim a Liga Comercial Alemanha-Brasil, que não era uma câmara de comércio no sentido regular do termo, mas uma associação privada de indústrias e comerciantes, mantida por cotas em marcos alemães. A Liga foi a responsável pelo desenvolvimento de projetos visando à internacionalização de empresas germânicas no Brasil. ${ }^{307}$

A admiração pelo incremento tecnológico que estava sendo empreendido no Império Alemão contaminava a sociedade brasileira e produzia momentos como o protagonizado pelo diplomata Itiberê da Cunha, que estava na Alemanha participando do Congresso TeutoBrasileiro. Ele defendeu em artigo publicado no jornal Berliner Tageblatt uma maior integração entre os dois países de tal ordem que o Brasil pudesse aproveitar o 'desenvolvimento rápido e sem igual' da Alemanha que já contava com grau tecnológico avançado e que estaria em condições de ajudar a nação brasileira a explorar melhor os seus próprios recursos. O diplomata baseou sua opinião na experiência que o Sul do Brasil estava vivenciando com a colonização germânica que fomentara as condições para 'uma relação mais estreita entre as duas nações' ${ }^{308}$

A força e a fama do Império Alemão colocavam a questão da colonização como assunto de primeira grandeza, tema polêmico antes mesmo da guerra. Muito se discutia quanto aos riscos e benefícios que a proximidade entre dois povos tão distintos e desiguais em

\footnotetext{
306 'Estrada de ferro', O Estado de S. Paulo, 25 julho 1912, p. 3.

307 'O Brasil no estrangeiro', O Estado de S. Paulo, 24 julho 1912, p. 7.

308 'Cartas de Pariz', O Estado de S. Paulo, 08 setembro 1912, p. 1
} 
termos econômicos e militares poderia resultar. Naquele contexto, tudo indicava que o lado do Brasil na guerra tendia a ser o contrário da Alemanha e uma aproximação entre os dois países não poderia prosperar. Silvio Romero foi dos nomes que atacaram com violência a expansão germânica. Muita repercussão obteve seu artigo intitulado "Alemanismo no Sul do Brasil” no qual abordou os riscos inerentes à rápida transformação dos estados do Sul em colônia alemã controlada pelo Império Alemão. ${ }^{309}$ No início do século XX, este risco parecia iminente muito porque a formação da Alemanha era assunto recente de grande impacto cultural. Este era um tema debatido em diversas esferas da sociedade ocidental, incluindo as forças armadas de países que passaram a estudar as estratégias de Bismarck nas academias militares e a incorporação de métodos prussianos na sociedade. ${ }^{310}$

Santa Catarina representava o estado no qual a situação da colonização era vista com maior preocupação, pois o grau de influência que empresários e políticos com ascendência germânica conquistaram na sociedade local permitiu o estreitamento de relações com o governo alemão em questões que envolveram negócios em diversas áreas, como os acordos comerciais com a Die Hanse (Liga Hanseática). Esta instituição mercantilista criara a base para uma poderosa e agressiva organização de comércio exterior com base em HamburgoLübeck que mantinha investimentos para atender interesses espalhados em todos os continentes. O estado de Santa Catarina foi escolhido pelos empresários alemães como a melhor porta para estabelecer negócios com o Brasil. ${ }^{311}$ As relações da sociedade catarinense com o povo germânico se estreitaram e eram de tal ordem que o estado manteve Felipe Schmidt como presidente durante a guerra. Isto ocorreu apesar das ameaças de grupos políticos rivais e de muitas investidas na imprensa que identificavam no filho de alemães e germanófilo uma ameaça à integridade do Brasil. ${ }^{312}$

Santa Catarina ganhou projeção nacional com estas idiossincrasias, mas o estado passou a ser observado com atenção ainda maior para o que ocorria em seu território devido ao espaço que Lauro Müller ocupava no cenário nacional. Nascido em Itajaí, Müller foi

\footnotetext{
${ }^{309}$ O Estado de S. Paulo, 26 junho 1912, p. 4.

310 Para aprofundamento nas influências do militarismo alemão, ver: Bentivoglio, Cultura política $e$ historiografia alemã no século XIX: a Escola Histórica Prussiana e a Historische Zeitschrift.

Para a mobilização social por meio do militarismo prussiano, ver: Castro, In corpore sano: os militares e a introdução da educação física no Brasil.

311 'As vendas de terras a capitalistas estrangeiros', O Estado de S. Paulo, 6 novembro 1912, p. 1.

312 Felipe Schmidt, político ligado ao PRC (Partido Republicano Catarinense), foi presidente de Santa

$\begin{array}{lllllllll}\text { Catarina entre } 1898 \text { e } 1902 & \text { e } & \text { novamente } & \text { entre } & 1914 & \text { e } & 1918 .\end{array}$ http://www.casamilitar.sc.gov.br/governadores.asp

'Notas de paz e guerra - Cartas do Rio', O Estado de S. Paulo, 04 novembro 1917, p. 4.
} 
presidente do estado em diversos períodos e ministro das Relações Exteriores entre 1912 e 1917. Com o início da guerra, o chanceler passou a colecionar críticos na Capital Federal que o atacavam de maneira aberta e intensa. A pressão foi aumentando na medida em que a imparcialidade brasileira passou a ser motivo de controvérsia em cenário internacional que era dividido entre países que pertenciam à Tríplice Aliança, à Tríplice Entente ou neutros, como o Brasil. A partir de abril de 1917, quando o Brasil rompe relações diplomáticas com o Império Alemão, a saída imediata de Lauro Müller no comando do Ministério das Relações Exteriores foi defendida junto a Wenceslau Braz, mas o presidente acreditava que o apoio que a diplomacia britânica dava ao nome do político catarinense bastaria para sustentá-lo no cargo até o final de 1918. Londres tinha em Müller um aliado para as questões mais complexas na relação comercial e financeira com o Brasil. Era como se o chanceler brasileiro quisesse demonstrar afastamento de suas origens germânicas por meio de atenção especial ao Reino Unido.

A situação de Müller foi alterada com a declaração de guerra que o governo brasileiro assinou em outubro de 1917. Este ato teve que ser respaldado com troca no comando do Ministério das Relações Exteriores porque passou a não fazer sentido vincular a imagem do Brasil no exterior na figura de um chefe da diplomacia com origem germânica. Defender Müller passou a ser tarefa inviável frente à nova missão internacional que faria o Brasil participar efetivamente da guerra. Poucas semanas depois, Nilo Peçanha foi empossado como novo ministro. ${ }^{313}$

Entender a relação de Müller com o governo brasileiro ajuda na compreensão do cenário no qual o Brasil tanto hesitou em ter que assumir posição durante a guerra. As influências positivas que a Alemanha conseguia lograr nos negócios do Brasil explicam a controvérsia que foi o país ter como representante internacional durante a guerra um dos expoentes do sucesso da colonização boche no Sul. Os diversos assuntos importantes que tiveram a chancela de Lauro Müller, discutidos ao longo deste capítulo, teriam provavelmente ocorrido em clima significativamente menor de polêmica se o mandatário das Relações Exteriores tivesse origem outra, elemento indicativo do grau de dubiedade que envolvia a economia brasileira durante a guerra.

As relações econômicas da Alemanha com o Brasil foram beneficiadas com a imagem positiva que o país germânico já possuía no mundo. Esta imagem foi ampliada com o sucesso

313 'Cartas do Rio', O Estado de S. Paulo, 21 abril 1917, p. 4. 
do processo de unificação dos reinos germânicos comandado pela Prússia ao final do século XIX e que levou à formação do Império Alemão em 1871. O rápido desenvolvimento econômico e social nos antigos reinos teutônicos, já no início do século XX, foi classificado como padrão a ser seguido em diversas partes do mundo porque indicava que evolução tão rápida havia sido fruto de processo perfeito. Este modelo poderia ser adaptado com grandes chances de sucesso, em países de formação industrial incipiente, caso do Brasil. O fato de máquinas produzidas com tecnologia alemã figurarem nos catálogos do comércio importador do mundo todo ajudou a sedimentar esta imagem de país moderno que era capaz de criar soluções automatizadas para as mais diversas áreas, inclusive para panificadoras que em São Paulo estavam importando amassadeiras alemãs que prometiam revolucionar o importante setor da panificação. ${ }^{314}$

Progresso tecnológico combinado com bem estar social passou a ser algo reverenciado com mais afinco no mundo, motivo pelo qual os países da Entente tiveram que investir em muita contrapropaganda como forma de modificar esta imagem de mundo alemão idílico. No Brasil, às ações de difamação do Império Alemão praticadas pela Entente foram adicionadas várias restrições para o comércio exterior do país. Este era o ponto mais vulnerável da economia nacional e a melhor maneira da diplomacia britânica pressionar as autoridades brasileiras no sentido de afastamento da área de influência alemã. O objetivo era levar o Brasil a um posicionamento firme de parceria com Londres e seus aliados na tarefa de liquidar a imagem positiva que o desenvolvimento alemão transmitia.

A política exterior do Brasil parecia dúbia porque era patente que a fragilidade da economia nacional não permitiria ao Brasil melindrar a Alemanha, como se dizia na imprensa da época, porque estavam em jogo relações comerciais de grande peso para a economia brasileira. O receio era como o Brasil faria para retomar o pagamento da dívida externa se as exportações estavam extremamente prejudicadas com os bloqueios e com a extinção do comércio com os países da Aliança. Para piorar o quadro geral, não havia sinal de boa vontade do Reino Unido em ajudar o Brasil a atravessar esta fase de exceções.

As dificuldades no mercado interno cresciam e começaram a aparecer sinais inequívocos de intolerância à influência germânica na política brasileira, visto que a neutralidade indispunha o país com a economia internacional. Londres não permitiria a volta da normalidade nas exportações de café e cacau, como acreditava a imprensa, enquanto o

\footnotetext{
314 ‘Amassadeira Herbst', O Estado de S. Paulo, 26 janeiro1913, p. 13.
} 
Brasil não entrasse formalmente para a Entente. ${ }^{315}$ Neste contexto de indefinições, quem mais perdia eram os produtores agrícolas, justamente os responsáveis por conseguir ouro em um mercado internacional cada vez mais fechado.

\section{Seção 8.2 - Neutralidade e negócios internacionais}

A neutralidade se transformara na vidraça do governo federal e o nome de Lauro Müller passou a figurar neste começo de 1917 como o responsável pelas dificuldades econômicas cada vez mais graves que não cessariam enquanto os interesses alemães fossem salvaguardados pelo Ministério das Relações Exteriores. ${ }^{316}$ Neutralidade passou a ser sinônimo de ter navios nacionais afundados pelos alemães e não poder vender produtos para os aliados. Estes mesmos aliados detinham o poder de proibir navios de outras bandeiras de servir portos brasileiros, deixando o país isolado e sem recursos suficientes para aguardar o fim da guerra. A diplomacia brasileira reagia dizendo que o lado bom da neutralidade era que o Brasil não tinha rompido com a Alemanha, ou seja, as pontes do comércio exterior com os principais compradores do café brasileiro poderiam ser refeitas quando o armistício fosse assinado.

Tendo como base as críticas à neutralidade brasileira, poderia se imaginar que o país era um caso atípico nas Américas por manter laços formais nas relações internacionais com o Império Alemão. Como mostra a Figura 8.1, o que realmente ocorreu demonstra que o Brasil foi, na verdade, o primeiro país latino-americano a romper com os alemães e um dos poucos a declarar guerra à Berlim. Para completar, o Brasil foi o único país da região a mobilizar e enviar força naval para lutar contra os países da Aliança. ${ }^{317}$

Figura 8.1 - Relações diplomáticas entre países do Continente Americano e o Império Alemão.

$\begin{array}{lcc}\text { Império Alemão. } & \text { Rompimento } & \begin{array}{l}\text { Declaração } \\ \text { de guerra }\end{array} \\ \text { País } & 13 / 04 / 1917 & \\ \text { Bolívia } & 11 / 04 / 1917 & 26 / 10 / 1917 \\ \text { Brasil } & & 04 / 08 / 1914 \\ \text { Canadá } & 21 / 09 / 1917 & 23 / 05 / 1918 \\ \text { Costa Rica } & & 07 / 04 / 1917 \\ \text { Cuba } & & \end{array}$

Equador

$08 / 12 / 1917$

315 South American Attitude to Germany, Treasury 5100, 13 fevereiro 1917, carta do Treasury Chambers datada de 17 fevereiro 1917.

316 'Cartas do Rio', O Estado de S. Paulo, 07 março1917, p. 2

${ }^{317}$ Goldstein, Wars \& Peace Treaties 1816- 1991. 
Estados Unidos

06/04/1917

Guatemala

$23 / 04 / 1918$

Haiti

$12 / 07 / 1918$

Honduras

$19 / 07 / 1918$

Nicarágua

$06 / 05 / 1918$

Panamá

Peru

$06 / 10 / 1917$

Uruguai

$07 / 10 / 1917$

Fonte: Goldstein . Wars \& Peace Treaties 1816-1991.

Argentina, Chile e Venezuela não constam da tabela em questão porque mantiveram posição de neutralidade durante todo o conflito. Nos casos de perda de patrimônio - supressão de frota mercantil, principalmente - provocada pelas forças navais da Aliança, estes países decidiram mover processos de reparação econômica por meio de suas representações junto ao governo alemão. ${ }^{318}$

No Brasil, o naufrágio de navios por motivos diretamente relacionados à guerra, combinado com pressão exercida por Londres e posteriormente por Washington, levaram a uma sucessão de eventos que forçaram a ruptura das relações diplomáticas com a Alemanha em 11 de abril de 1917. Internamente, a reação da sociedade foi violenta, como se o ressentimento contra os alemães houvera sido liberado e incentivado, resultando em centenas de empreendimentos atacados, principalmente em Porto Alegre. ${ }^{319}$ Após seis meses, veio a declaração de guerra. O longo tempo transcorrido entre estes atos demonstra o grau de hesitação que dominava o governo Wenceslau Braz, que ainda tentava evitar a ação drástica de novembro de 1917 com receio da reação revanchista que a Alemanha poderia ter no pósguerra.

O simbolismo destes eventos nas relações exteriores do Brasil eclipsou incidentes durante a guerra que foram representativos das dificuldades de um país neutro e que não queria abandonar esta situação. Esta posição de neutralidade foi algo longe de confortável em termos de política interna e externa. Ao final de maio de 1915, por exemplo, foi votado o projeto na Câmara dos Deputados que revogava a neutralidade do Brasil na guerra. Apesar de não ter tido efeito oficial, as reações foram imediatas com ataques registrados a diversas empresas de capital alemão que tinham base no Rio de Janeiro, como a Casa Arp, a Fábrica de

\footnotetext{
318 Ibidem.

319 'Gravissimos successos em Porto Alegre', jornal A Época, 17 abril 1917, matéria de capa.
} 
Papelão Oscar Rudge, o Clube Germânia e o Bar Brahma. A imprensa reprovava estas manifestações e indicava que os verdadeiros alvos deveriam ser os banqueiros alemães. Havia a convicção que as riquezas do Brasil estavam sendo drenadas há muito tempo por bancos que eram verdadeiros agentes financeiros da nobreza germânica e que pretendiam construir um império que dominaria grande parte do mundo. ${ }^{320}$ Como reação a este temor, a guerra levantou questões que discutiram a ideia da nacionalização do comércio, proibindo a participação de empresários estrangeiros. Apesar da insatisfação com as condições econômicas, medida tão extrema não poderia ser adotada porque era bastante reduzida a participação de empresários de origem brasileira no setor de serviços. ${ }^{321}$

A partir de abril de 1916, com a declaração de guerra do governo português ao Império Alemão, a pressão para que o Brasil assumisse uma posição mais definida no conflito aumentou. O problema era que, como verificado em outros momentos da guerra, uma tomada de decisão desta envergadura pelo governo brasileiro implicaria ter que enfrentar a reação dos cafeicultores e demais exportadores de commodities agrícolas que preferiam a neutralidade "à brasileira", sabidamente tendenciosa aos países da Entente, mas sem afrontas aos impérios centrais. Era preferível esta posição a dinamitar as parcerias comerciais com as empresas de capital alemão que tão solidamente estavam instaladas nos principais negócios do Brasil. ${ }^{322}$

Como medida que procurou ajudar a enfrentar a questão do torpedeamento dos navios brasileiros sem a necessidade de enfrentar Berlim com a declaração de guerra, a Federação Marítima Brasileira se reuniu e decidiu aconselhar o governo brasileiro a evitar que os navios de bandeira nacional entrassem em zonas de conflito. As embarcações deveriam atracar somente em portos livres, reconhecidos como tais pelo Império Alemão. O problema é na maioria dos casos estes portos livres estavam sob controle da Marinha Alemã. Se o conselho fosse seguido, o Brasil estaria se submetendo ao bloqueio alemão e automaticamente contrariando as estritas regras do War Trade Department.

A imprensa deu voz aos críticos e a especialistas em estratégias de guerra que acusaram a instituição naval de conluio com Lauro Müller e culpavam o chefe da Federação Marítima, Müller dos Reis - presidente da Companhia Lloyd de Navegação e sobrinho de Lauro Müller - como articulador desta grande manobra internacional.

\footnotetext{
320 'Cartas do Rio', O Estado de S. Paulo, 30 maio 1917, p. 4.

321 'Cartas do Rio', O Estado de S. Paulo, 14 dezembro 1917, p.3.

322 'Cartas do Rio', O Estado de S. Paulo, 16 maio 1917, p.3.
} 
Opiniões menos radicais e mais focadas no mundo do comércio exterior explicavam que o real interesse de Müller dos Reis era o de aumentar o lucro da Companhia Lloyd, empresa que não tinha linhas regulares para os principais portos da Europa e que estava em busca de opções na logística internacional, mesmo que isto significasse utilizar portos controlados pelo Império Alemão. ${ }^{323}$

As investidas contra as relações comerciais que empresários brasileiros mantinham com empresas alemãs eram consideradas o resultado da propaganda que Berlim decidiu intensificar nos países latinos a partir de 1914. Prospecto da Sociedade Ibero-Americana (Ibero-Amerikanischeverein) de Hamburgo deixou registrada a relação que estrategistas do governo alemão identificavam entre elementos da chamada "civilização alemã elevada" e aspectos comerciais que o capital germânico estabelecera com a Espanha e América Latina. Neste material de circulação controlada pelo governo alemão, a ideia essencial era combater as "calúnias" que a Entente implantava contra o povo germânico entre países que tendiam a continuar a ser bons parceiros para as empresas alemãs após o início da guerra.

Acreditando que existia uma situação dicotômica entre a boa acolhida aos interesses alemães entre os povos latinos e a imagem que os teutos carregavam de povos bárbaros, Londres encampou campanhas de difamação que criavam ou alimentavam o preconceito contra os germânicos. Berlim definiu que o antídoto para este envenenamento da cultura teutônica e da salvaguarda do modo alemão de fazer negócios deveria ser administrado por meio da aproximação intelectual com os países latinos. Isto se daria na forma do desenvolvimento do conhecimento técnico, da ciência e da educação, que eram considerados como elementos estratégicos e tácitos para ampliar a influência da economia alemã no mundo. Como exemplo de método a ser empregado, a Sociedade IberoAmericana citou os casos de sucesso obtidos pela França por meio da 'École des Langues Orientales', que avultou os interesses franceses na Rússia, Índia, Pérsia e Egito, países nos quais missões científicas precederam a instalação de empresas francesas. ${ }^{324}$

O combate às atitudes preconceituosas - que a propaganda alemã chamava de 'abgenutzte Glaubensbekenntnisse' - sobre os alemães deveria ocorrer por meio da capacitação dos povos latinos em Organização e Método e na Excelência da Manufatura, áreas nas quais o povo germânico se destacava e por isto deveria ser reconhecido. Esforços

\footnotetext{
${ }^{323}$ O Estado de S. Paulo, 15 março 1917, p. 3

${ }^{324}$ German propaganda in Spain and South America, janeiro 1916, FO 833/16/30279, vol. 1, p. 1-3.
} 
neste sentido deveriam ser estimulados porque os resultados seriam perenes e benéficos para produtos com a marca alemã. O que a França havia conquistado em termos de imagem na América Latina pavimentava o caminho do sucesso de seus produtos na região e isto foi feito com a disposição plena de professores capacitados para fundar cursos e universidades entre os latinos. A região passou a receber missões francesas que organizaram clubes de artes e negócios, revistas e jornais foram abertos e mantidos com recursos franceses. Na França, a cultura hispânica passou a ser mais divulgada, o ensino do espanhol incentivado. Em termos de turismo, navios franceses foram incentivados a oferecer descontos de até $50 \%$ em passagens para países da América Latina. Tudo com o propósito de aproximar os povos e enaltecer o que os franceses produziam de melhor. A Aliança Francesa era um excelente parâmetro para o que o Império Alemão deveria colocar em prática visando erradicar o espírito beligerante contra a cultura teutônica em países neutros. ${ }^{325}$

Para o Reino Unido, a necessidade de esforços similares aos empreendidos pelos franceses era muito menor porque o poder financeiro que o país desenvolvia há muito na região atendia com sobras a difusão cultural do país entre os falantes de espanhol e português. Já os norte-americanos alicerçaram propaganda na América Latina tendo os princípios da liberdade e independência como base. O presidente Woodrow Wilson passou a reavivar a Doutrina Monroe como consequência do aumento do interesse do capital norte-americano na América Latina.

De acordo com a Sociedade Ibero-Americana de Hamburgo, apesar de ainda não terem atingido o patamar de desenvolvimento alcançado pelas nações europeias, muitos países latinos estavam em rápido processo de crescimento e em breve seriam palco de economias com capacidade de absorver cada vez mais produtos europeus. O Império Alemão não poderia perder a oportunidade de estar presente neste processo de evolução. No plano alemão para a região, o Brasil era colocado em destaque dado o potencial natural do país. A instituição cultural germânica dava como certo que os conflitos seriam vencidos por Berlim, mas, mesmo que isto não ocorresse, as nações europeias se digladiariam por um quinhão econômico no maior dos países latinos e a Alemanha não poderia correr o risco de perder as bases já assentadas no Brasil. ${ }^{326}$

\footnotetext{
${ }^{325}$ German propaganda in Spain and South America. Op. Cit. p. 5-7.

326 Ibidem, p. 5-7.
} 
A conquista de mais espaço para os negócios alemães na América Latina não se restringia aos estudos que a Sociedade Ibero-Americana de Hamburgo empreendia. Havia ainda o Instituto Teuto-Sulamericano que publicava informativos especiais sobre os países latinos, com análise de dados socioeconômicos para as principais regiões do país. Apesar desta aparente predileção pelos latinos, a economia internacional interessava como um todo para o Império Alemão. Em termos de Ásia, a Liga Teuto-Chinesa tinha a preocupação de identificar os pontos de comércio do país asiáticos que ficariam disponíveis após o fim da guerra. $\mathrm{Na}$ análise do governo alemão, o Reino Unido não poderia ser destruído nas batalhas, mas sairia da guerra bastante enfraquecido, o que abriria oportunidades para empresas alemãs. O concorrente a ser estudado e vencido na Ásia era o Japão, já considerado potência regional. Berlim acreditava o país asiático teria o poder econômico fortalecido com o crescimento do comércio junto aos países vizinhos e por conta das novas fronteiras de negócios que se abririam no Pacífico, região de atuação preferencial de Tóquio. ${ }^{327}$

O poder das empresas alemãs de ganhar mercados em condições adversas foi analisado no periódico Das Grossere Deutschland que publicou artigo com o título "O comércio exterior da Alemanha no pós-guerra" no qual o autor Otto Sperber analisou as exportações realizadas pelo Império Alemão antes e durante a guerra. Sperber concluiu que apesar dos esforços concentrados do Reino Unido e da França em bloquear e isolar a Alemanha, a tecnologia aplicada aos produtos alemães de exportação conseguiu manter e até mesmo ampliar a participação em colônias das potências da França e do Reino Unido. $\mathrm{O}$ artigo afirma que a possibilidade de encontrar qualidade elevada e preço baixo em uma manufatura alemã superava as circunstâncias adversas da guerra e propiciava a penetração da Alemanha em praticamente qualquer mercado. Citando os países da América do Sul, Sperber avaliou que muitos estavam enfrentando severas restrições financeiras o que os levou a reduzir consideravelmente a demanda por produtos franceses e britânicos. Os bancos tradicionais destes países que operavam na região estavam fechando as portas ou restringindo de maneira drástica as linhas de crédito para as importações em geral. $\mathrm{O}$

\footnotetext{
${ }^{327}$ Mitteilungen des Deutsch-Südamerikanischen Instituts, setembro 1915, FO 833/16/30279, vol. 2, p. 1-5. Der Deutsch-Chinesischer Verband, 1916, FO 833/16/30279, vol. 3, p. 1-5.
} 
resultado teria sido a redução da participação dos produtos da França e do Reino Unido nos mercados sul-americanos. ${ }^{328}$

No Brasil, os produtos alemães não teriam perdido mercado porque os bancos do Império Alemão estavam capitalizados e preparados para financiar operações de comércio exterior de artigos para os quais os comerciantes locais não achavam substitutos, especialmente máquinas para indústrias, químicos e farmacêuticos. Sperber destacou que nenhum banco alemão teve que fechar as portas por falta de recursos desde o início da guerra em nenhum país sul-americano. Com a pressão do comércio importador brasileiro a favor de artigos que continham o Hergestellt in Deutschland (feito na Alemanha), a batalha contra os produtos de outras procedências estava sendo vencida, apesar de todas as barreiras físicas e psicológicas montadas pela Entente ${ }^{329}$

A principal orientação que Berlim dava às empresas alemãs exportadoras era manter o máximo de contato possível com os seus clientes ao redor do mundo, mesmo que as condições impostas pela guerra limitassem o acesso aos mercados consumidores. Para além do lucro, o objetivo era garantir que a demanda no pós-guerra pudesse ser retomada do ponto onde havia parado. Os clientes identificados com a qualidade alemã tenderiam a ser fieis às marcas alemãs após o fim dos conflitos, não importando o resultado em termos militares. O artigo buscou desvincular o prisma comercial do prisma político-militar e, utilizando de pragmatismo econômico, defendeu a continuidade da excelência alemã na economia internacional no pós-guerra, momento no qual as nações importadoras dos manufaturados alemães estariam sufocadas pela falta de ouro. Esta seria uma grande oportunidade para a Alemanha negociar em melhores condições e oferecer a estes países contrapartidas, principalmente a utilização de produtos primários como moeda de troca no fornecimento de manufaturados. ${ }^{330}$

A aquisição de produtos industriais alemães no Brasil seguia precisamente esta lógica de vender café para adquirir tecnologia de ponta a preços acessíveis. A participação da Alemanha no comércio exterior brasileiro antes da guerra causou dependência no Brasil para as exportações de café. Isto veio a ser um grave e inesperado problema quando do rompimento da guerra pois era grande a quantidade de café nos vários estágios das

\footnotetext{
${ }^{328}$ German foreign trade after the war, artigo de Otto Sperber, dezembro 1915, FO 833/16/30279, vol. 4, p. 1 e 2 .

${ }^{329}$ Ibidem.

${ }^{330}$ Ibidem, p. 3-5.'
} 
transações comerciais que foram paralisadas com o início dos conflitos. O resultado foi a retenção de grande quantidade de sacas em território alemão. Algumas destas transações com empresários alemães eram de tal ordem que mesmo com a guerra o mercado continuou ativo. Esta situação foi verificada no porto de Bremen, que concentrava grande quantidade de café precisamente no auge das movimentações da política internacional para forçar os países neutros a declarar guerra à Aliança. ${ }^{331}$

Na opinião dos diplomatas britânicos, esta questão de ativos brasileiros apreendidos pelo Império Alemão era das mais complexas e que muito trabalho de bastidores exigiria. O Ministério das Relações Exteriores do Reino Unido deveria aproveitar a oportunidade para cobrar vantagens precisas do governo brasileiro em caso de sucesso na liberação dos recursos relacionados ao café apreendido por Berlim. Em análise efetuada pelo Departamento do Tesouro e sumarizada por Keynes, o ponto central da questão era financeiro e envolvia garantias que o Tesouro Britânico deveria dar ao governo brasileiro de que os valores correspondentes ao café estocado em portos alemães e no porto de Antuérpia seriam creditados ao Brasil. Keynes assumia que a quantidade de café era muito elevada, totalizando algo como $£ 8$ milhões, fruto do Plano de Valorização elaborado e administrado pelo estado de São Paulo que emitiu títulos lastreados no produto para poder obter crédito na Europa. Isto deixava o caso ainda mais complicado porque parte dos recursos para São Paulo foi repassada por bancos alemães, instituições que ainda estavam envolvidas nas operações de café do Brasil. O valor que o Governo Brasileiro pleiteava e sobre o qual solicitava cobertura do Tesouro Britânico não era, portanto, verdadeiramente pertencente ao país. Tudo isto, concluiu Keynes, era baseado em impressões que o conhecimento dele de assuntos correlatos permitia comentar. A veracidade dos fatos deveria ser estabelecida antes que qualquer outra ação fosse executada, e isto somente seria possível se fossem acionados os banqueiros das casas Rothschild e Schröder. ${ }^{332}$

Este caso do café apreendido nos portos alemães era um dos obstáculos que a representação diplomática britânica identificava junto ao governo brasileiro quando a pressão aumentou para que o país se posicionasse contra a Alemanha. O que o Ministério da Fazenda do Brasil indicou a Wenceslau Braz era que os aliados deveriam garantir o valor devido pelo Império Alemão, caso o rompimento das relações fosse negociado junto

\footnotetext{
${ }^{331}$ South American attitude to Germany, fevereiro 1917, T 1/12112/5100, carta do Treasury Chambers de 17 fevereiro 1917.

${ }^{332}$ Ibidem.
} 
ao Congresso e chancelado pelo Presidente. Londres entendeu que, para poder contar efetivamente com o Brasil na guerra, este deveria ser um dos pontos passíveis de solução. O outro era o distanciamento que deveria ser trabalhado para desvincular a atitude brasileira da que os Estados Unidos tomaram ao declarar guerra à Aliança. Para poder atender aos anseios da elite brasileira, representada em parte pelo Congresso, o presidente brasileiro informou ao governo britânico que não seria possível tomar nenhuma atitude contra o Império Alemão enquanto a imprensa, brasileira e internacional, estivesse contagiada por comentários sobre a decisão de Washington de romper com Berlim, medida tornada efetiva em 3 de fevereiro de $1917 .{ }^{333}$

Londres avisou que o Brasil deveria se comprometer, no mínimo, a se distanciar dos interesses alemães e a incrementar ações diplomáticas junto aos vizinhos latinos para que fizessem o mesmo. Ações da diplomacia brasileira neste sentido foram executadas e comprovadas: com exceção da Argentina que ainda se ressentia de não ter recebido suporte dos aliados quando de suas reclamações sobre a Statutory List, Peru, Bolívia, Chile e Uruguai emitiram protestos oficiais em linha com o que já fizera a Espanha. ${ }^{334}$ Lendo com atenção a atitude do governo brasileiro, fica patente que o país estava aproveitando a situação para barganhar o seu afastamento dos interesses econômicos com os alemães para em troca assumir um papel de liderança na América do Sul. Para esta empreitada contava com o suporte dos países da Tríplice Entente no sentido de bloquear procedimentos dos Estados Unidos na região, única maneira que o Brasil identificava como possibilidade de ampliar os seus interesses estratégico-militares internacionais. ${ }^{335}$

Este momento de ter que demonstrar opção clara por um dos lados na guerra era de grande dificuldade para o governo brasileiro. Os empresários germânicos estavam há décadas envolvidos com o comércio do café, relação que acabou aproximando fornecedores da Alemanha de importadores no Brasil, criando um vínculo que parecia vantajoso para ambas as partes. A guerra travou as operações com o café e limitou consideravelmente as importações, mas era dado como certo no mercado que tudo voltaria como antes após o armistício, porque não se tratava, afinal, de uma guerra ideológica, mas sim de um rearranjo de poderes em termos geográficos, essencialmente no Leste Europeu.

\footnotetext{
333 “Brazil-Military, Trade and Treat”, fevereiro de 1917, T 1/12112/5100, carta de Arthur Peel datada de 8 fevereiro 1917

334 "Statutory List" foram regras que conduziram a prática de bloqueio comercial e econômico contra o Império Alemão que a Entente desenvolveu durante a PGM. Tema faz parte do Capítulo III.

335 "Brazil-Military, Trade and Treat", Op. Cit.
} 
Não havia, portanto, motivo para que as relações econômicas do Brasil com a Alemanha não voltassem ao ponto no qual foram obstadas. Isto pode ser comprovado pelo receio que a diplomacia britânica em Londres e no Rio de Janeiro demonstrou ao longo do conflito de que, se nada fosse feito, o capital alemão voltaria a dominar totalmente o comércio do café no pós-guerra. Se isto ocorresse, os empresários britânicos teriam perdido uma excelente oportunidade, talvez a última, para participar de maneira mais direta do lucrativo negócio do café, corrigindo grave falha no comércio internacional britânico. ${ }^{336}$

Naquele contexto de guerra, o que o governo britânico deveria fazer era ajudar o Brasil a enfrentar o bloqueio que impedia que grande parte da produção cafeeira chegasse aos consumidores finais na Europa. O cerne do problema era que o isolamento da Áustria e da Alemanha do comércio com as Américas aumentava o estoque de café nos portos brasileiros exatamente porque os maiores negociadores do produto tinham base nestes países. O Reino Unido estava sendo pressionado a comprar este excesso de café que tinha como destino original os portos alemães. Caso isto não fosse viável, o governo brasileiro solicitava que fosse emitido um crédito pelo equivalente do café que não podia ser exportado. Se nada fosse feito, corria-se o risco de o Brasil voltar para o esquema comercial no qual o capital alemão detinha grande fatia do mercado. Outro risco era o de Nova York conquistar de vez a parte do financiamento ao governo brasileiro e, como indicava a própria chancelaria britânica, o que não faltavam na praça eram bancos norteamericanos interessados em substituir os bancos britânicos no ciclo que parecia eterno de empréstimos e consolidação da dívida brasileira. ${ }^{337}$

As ligações do capital alemão com a economia brasileira foram largamente utilizadas durante a guerra para insuflar a revolta na sociedade contra as proibições de exportação de café para países neutros. Londres acreditava que a posição de beligerância em relação à lista de exceção adotada pelo Jornal do Commercio teria sido reflexo dos esforços da propaganda alemã que conseguiu convencer os editores do periódico que as medidas de restrição de exportações adotadas pela Entente tinham se tornado um verdadeiro programa para reduzir a soberania brasileira. Tal atitude era algo vexatório e que deveria ser combatido enquanto era tempo, antes que outras medidas ainda mais humilhantes para o Brasil fossem tomadas. A indignação do jornal era centrada nos casos

\footnotetext{
${ }^{336}$ Brazilian Coffee Situation, novembro 1916, FO 371/2640, memorandum nr. 231061/16 'To the King and War Committee', p. 198.

${ }^{337}$ Brazilian Coffee Situation, novembro 1916, FO 371/2640, memorandum nr. 231061/16 'To the King and War Committee', p. 199 e 200.
} 
nos quais os aliados estavam ditando regras no comércio entre o Brasil e países neutros. Se esta tinha passado a ser a regra no atual estágio da guerra, a pergunta que o jornal colocava era porque a mesma medida não foi adotada contra os Estados Unidos que estavam comercializando livremente os seus produtos junto a todos os países neutros do mundo. ${ }^{338}$

O que inflamou os ânimos em escala nacional e que a diplomacia britânica considerou uma situação perigosa foi a proibição da exportação de café para a Companhia de Comércio Exterior da Holanda. De acordo com as estatísticas do Departamento Britânico de Comércio da Guerra, a empresa holandesa estava adquirindo quantidades do produto muito acima da média consumida nos Países Baixos em anos recentes, algo como seis vezes o total internado em 1913. Na análise do Departamento Britânico de Comércio da Guerra, duas poderiam ser as explicações: o café em excesso estava sendo estocado ou a quantidade que ultrapassava em muito o consumo estava sendo direcionada para as Potências Centrais. Como a Entente tinha certeza que o café estava mesmo sendo redirecionado para a Alemanha, impôs-se o bloqueio. Era medida que o corpo diplomático britânico acreditava deveria ter sido aceita naturalmente pela sociedade brasileira, não fosse a contrapropaganda germânica que conseguiu dividir a opinião pública de tal modo que os brasileiros estavam naquele momento - final de 1916 - prontos para apoiar qualquer dos lados na guerra. ${ }^{339}$

A diplomacia britânica avaliou que não deveria ser perdida a tendência natural do governo brasileiro de se posicionar ao lado da Entente. Para tanto, Londres deveria capitanear esforços para que a situação financeira do país fosse amenizada, principalmente porque eram visíveis os sinais dos problemas que o bloqueio ao comércio exterior estava criando para as finanças do país. Esta situação não deveria ser negligenciada em hipótese alguma porque eram críveis demais os relatos que chegavam do Sul do país dando conta que os três estados da região, especialmente o Rio Grande do Sul e Santa Catarina, não seguiam as diretrizes estabelecidas nos gabinetes do governo federal e se transformaram em estados com elevado grau de independência. ${ }^{340}$

Dada a formação étnica das populações destes estados que contavam com marcante presença germânica, a tendência dos governos locais era apoiar de maneira aberta a

\footnotetext{
338 “Brazilian press and public opinion”, dezembro 1916, FO 371/2640/247583, p. 247-251.

${ }^{339}$ Ibidem.

340 “German inlfuence in Brazil”, março 1917, FO 371/2900/46761, p. 334-336.
} 
Alemanha na guerra. O relato do Sr. Bayne, gerente da Companhia Ferroviária Uruguai Central, sobre as intenções de as províncias do Sul do Brasil de estruturar uma separação do restante do país fez soar alertas em Londres porque o temor era que o Império Alemão atuava nos bastidores deste movimento. Dadas as relações do Sr. Bayne com o governo uruguaio, Londres tomou ciência que o presidente daquele país tinha muitos elementos que comprovavam que o intuito era até mesmo maior, que o escopo dos estados sulistas brasileiros era induzir o Uruguai a fechar um acordo para com eles formar um país na América do Sul que fosse parte integrante do Império Alemão. ${ }^{341}$

A opinião da diplomacia britânica no Uruguai via a situação de maneira sensivelmente menos alarmante ao afirmar que apenas o estado de Santa Catarina poderia em algum momento conjecturar uma independência. $\mathrm{O}$ risco, por mais improvável que parecesse dadas as relações comerciais do estado com o Brasil, não deveria deixar de ser observado. Na opinião da diplomacia britânica, questões relacionadas aos sentimentos de união étnica pesam sempre muito mais que questões econômicas, como o provavam os fatos que ocorriam naquele momento no Canadá. ${ }^{342}$

Há muito que o receio de desmembramento do Brasil era recorrente, principalmente dos estados do Sul, mas durante a guerra os movimentos sociais que apregoavam a secessão se intensificaram e ganharam uma orientação que a Entente identificou como tendo origem principal o apoio do Governo Alemão em uma operação com características de complô. Foi por meio deste prisma que os países aliados avaliaram o polêmico episódio da importação de armas para o Rio Grande do Sul. Em carta do correio diplomático britânico assinada por William Lacklan é relatada a entrada no Brasil de diversas caixas com armas da empresa Winchester and Colts Arms negociadas por intermédio de agentes pró-alemães nos Estados Unidos e que tinham como destinatário final empresas de origem germânica instaladas no Rio Grande do Sul. De acordo com levantamento recebido pela chancelaria britânica, estes revólveres e espingardas foram importados com autorização do presidente do estado, Borges de Medeiros, para que fosse iniciada uma revolta local durante a Primeira Guerra Mundial com vistas à separação do Brasil e à transformação do estado gaúcho em um membro do Império Alemão. Medeiros, de acordo com o documento, teria apoiado esta manobra para que ele fosse empossado imperador pelos alemães. Esta operação poderia parecer fantasiosa, mas os especialistas europeus em

\footnotetext{
${ }^{341}$ Ibidem.

${ }^{342}$ Ibidem.
} 
estratégias da Alemanha afirmavam que era algo que se encaixaria à perfeição na política do pangermanismo de Berlim que procurava expansão por meio de batalhas ou de cooptações onde houvesse germanofilia. ${ }^{343}$

As características da colonização alemã no Sul do Brasil foi tema dos mais estudados pelo governo britânico desde o final do século XIX. Estes estudos ganharam ímpeto durante a guerra não apenas pelos riscos de infiltração de agentes do Império Alemão no Brasil, mas especialmente devido à probabilidade real de fragmentação de uma parte importante do país em termos de recursos econômicos ou em razão das relações culturais da região com outros países da América do Sul, como Uruguai e Argentina. O perigo da instalação de uma base operacional alemã no Continente Americano mais do que justificava esforços como o empreendido no início da guerra e que gerou um extenso relatório no primeiro semestre de 1916 intitulado 'German Settlements in Brazil'. 344

Para diferenciar a colonização alemã no Brasil da que ocorria na África, a diplomacia britânica explicou que vários estados como Minas Gerais, Espírito Santo, Rio de Janeiro, São Paulo, Paraná, Santa Catarina e Rio Grande do Sul foram povoados naturalmente por população de origem germânica, ao contrário do que se verificou na Namíbia, onde o processo de povoamento foi organizado diretamente pelo Império Alemão. Os estados sulistas brasileiros mantiveram os costumes adquiridos na Suíça, Áustria e Alemanha de onde se inspiravam em modelos de agricultura, comércio e indústria. $\mathrm{O}$ idioma alemão era incentivado e a integração com a sociedade brasileira limitada, dando a este tipo de colonização um nítido caráter de segregação, fato que facilitou em grande medida a manutenção dos laços com as cidades e aldeias de onde partiram os grupos fundadores dos assentamentos no Brasil. Apesar de este quadro ter se repetido nos estados que receberam os imigrantes, duas diferenciações locais mereceram destaque no relatório do diplomacia britânica: no Rio Grande do Sul se instalou a maioria dos colonos, mas era em Santa Catarina que os colonos detinham poder econômico e político que realmente poderia alterar as estruturas do Brasil. ${ }^{345}$

Em São Paulo, a colônia alemã era relativamente inferior a dos estados sulistas, mas era o local no qual onde os imigrantes mais prosperaram. Esta ascensão social ocorrera por meio da participação em negócios lucrativos como o do café, no sistema

\footnotetext{
${ }^{343}$ German intrigues in Brazil, abril 1916, FO 371/2639/76878, p. 193-199.

344 'German Settlements in Brazil', maio 1916, FO 371/2639/99044, p. 200-09.

${ }^{345}$ Ibidem., p. 210-4.
} 
financeiro, na metalurgia e na logística. Um dos melhores exemplos pode ser encontrado no nome de Theodor Wille, que fundou uma empresa inconteste no mercado mundial de café da segunda metade do século XIX até pelo menos 1950. Este grande empreendimento deu origem à atual multinacional alemã TWI com sede em Frankfurt, empresa que após se desligar do Brasil passou a atuar nos ramos de navegação, energia elétrica e supply chain para diversas partes do mundo, com notável exceção da América Latina. ${ }^{346}$ Wille é um dos personagens mais presentes na historiografia que aborda a industrialização brasileira antes de 1930 porque o empresário estruturou negócios no Brasil em diversas áreas, como produção e exportação de café, companhia marítima, produção de cerveja e de energia elétrica. $^{347}$

Em relatório confidencial, a chancelaria britânica estimava que a população de origem alemã equivalesse a um terço do total de residentes no Rio Grande do Sul, metade da população de Santa Catarina e a um quinto da do Paraná, números que, somados a outros núcleos de colonização germânica no Brasil, totalizavam perto de um milhão de pessoas. ${ }^{348}$ Os dados não eram confiáveis, admitia a diplomacia britânica, porque muitos descendentes de alemães tinham se naturalizado brasileiros, mas de qualquer forma indicavam como era importante o papel desta comunidade no Brasil. Estas raízes incluíam a participação na economia e na política do Brasil de forma organizada e que se dava por meio do estabelecimento de escolas, igrejas e de empresas que seguiam os costumes germânicos e que se destacavam entre as congêneres brasileiras, especialmente as escolas que passaram a ser muito procuradas a partir do início do século porque as instituições públicas de ensino nacionais deixaram de oferecer disciplinas com conteúdo religioso. Nas escolas alemãs, as sociedades de difusão do pangermanismo eram responsáveis por ensino considerado de qualidade pela sociedade brasileira que valorizava a disciplina e a metodologia utilizadas. ${ }^{349}$

\footnotetext{
${ }^{346}$ Theodor Wille Intertrade, http://www.twipv.com/about-us.

${ }^{347}$ Ver: Portal da Prefeitura de Santos. Histórias e lendas de Santos: www.novomilenio.inf.br/santos/h0090d.htm

${ }^{348}$ Em 1920, a população brasileira chegou ao total aproximado de 29 milhões. Destes, estimativas do Departamento Nacional de Imigração e do Instituto Nacional de Imigração, indicam que perto de 1,6 milhão eram imigrantes, o que dava uma relação de 51,9 imigrantes para grupo de 1.000 habitantes. No Rio Grande do Sul esta proporção foi de 104,1/1.000. IBGE, Repertório Estatístico do Brasil - Quadros Retrospectivos, $\mathrm{n}^{\circ} 1, \mathrm{p} .12$.

${ }^{349}$ German Settlements in Brazil, Op. Cit. p. 215-6

Protestantische Deutsche in Brasilien. Eine Diskursgeschichte 1864 - 1945, Freie Universität Berlin.
} 
As questões culturais da influência alemã no Brasil eram bastante observadas pela diplomacia britânica, mas o verdadeiro problema para o Departamento Britânico de Comércio da Guerra era a capacidade de mobilização de forças e produção de riquezas que o capital alemão vinha conseguindo no Brasil com atividades que tinham começado na agricultura, mas que durante a guerra atingiram o comércio. Empresas alemãs já dominavam a totalidade do comércio exterior do estado de Santa Catarina, quase três quartos das importações do Paraná, além de grande destaque que desfrutavam na produção industrial de São Paulo. O café era de longe a principal área dos interesses alemães no Brasil e empresas como as de Francisco Schmidt e Theodor Wille foram responsáveis por importante fatia da produção e da distribuição do produto no mercado internacional. Em levantamento de 1907, o corpo diplomático britânico identificou 150 empresas alemãs de destaque, de capital alemão ou de proprietários com ascendência germânica, mas três em particular deveriam merecer vigilância constante da Entente porque eram corporações com afluência política: Theodor Wille com base em Santos, Karl Höpcke em Florianópolis, proprietário de importante companhia marítima, fábrica de gelo e tecelagens, e Martin Bromberg em Porto Alegre, proprietário da Bromberg \& Cia que atuava na importação de máquinas alemãs e que tinha participação em negócios diversos no Sul do Brasil. ${ }^{350}$

Karl Höpcke era considerado pelo serviço secreto britânico como o líder da comunidade germânica em Santa Catarina e o maior responsável pelos movimentos de propaganda difamatória contra os interesses britânicos no Brasil. Ele era também uma importante referência no armamento de milícias, como a que foi estruturada para lutar na zona de contestação de terras do estado do Paraná, a Guerra do Contestado. De acordo com a chancelaria britânica, atitudes como esta não passavam despercebidas pelas autoridades brasileiras com reações públicas de repúdio ao pangermanismo no Brasil. O senador Barbosa Lima era conhecido por mover campanha contra a desnacionalização do Sul do Brasil e o deputado federal Correa de Freitas alertava sobre os verdadeiros interesses dos assentamentos alemães. O governo britânico entendia que o governo federal tentava timidamente e sem sucesso enfraquecer esta concentração de poder alemão no país por meio do incentivo da instalação de colônias de outras nacionalidades, mas os inimigos continuavam fortes e poderosos e todo o cuidado era pouco para o risco que o espaço que

\footnotetext{
350 Bromberg \& Cia: http://facasriograndenses.blogspot.com.br/2013/03/blog-post.html\#!/2013/03/blogpost.html; Empresa Nacional de Navegação Hoepcke: http://www.novomilenio.inf.br/santos/h0430d.htm.
} 
os alemães ocupavam no Brasil em detrimento dos interesses gerais do Reino Unido na América do Sul. ${ }^{351}$

Durante os primeiros anos da guerra, as importações de produtos estratégicos pelo Brasil eram monitoradas pelo governo britânico. Havia comprovação que o Império Alemão desviava parte destes produtos para abastecer a indústria da guerra. $\mathrm{O}$ carvão foi destaque neste grupo de produtos estratégicos porque o Brasil passou a importar quantidade superior à média estabelecida como ponto crítico pelos especialistas da Entente. Em março de 1916, por exemplo, catorze navios alemães estavam no Porto do Rio de Janeiro carregados com quantidades elevadas do produto. Não ficou esclarecida a origem do carvão nos porões destas naves, mas um número tão elevado de embarcações de bandeira alemã ao mesmo tempo no Rio de Janeiro chamava muita a atenção. O receio maior era que pontos não observáveis na costa brasileira estavam sendo utilizados para passar carga para os inimigos. ${ }^{352}$ Estes pontos no litoral brasileiro poderiam perfeitamente abastecer portos controlados pela Marinha Alemã em vários pontos do Atlântico. Situação análoga ocorreu com minério de ferro, madeira, borracha dentre outros insumos que a Entente, com a representação diplomática britânica à frente, tentava controlar de diversas formas, principalmente pela ampliação do monitoramento das entradas e saídas de navios dos portos brasileiros. Além de verificar a carga com a qual estes navios atracavam e zarpavam, os informantes tinham que dar conta da situação da documentação das embarcações e das pessoas a bordo. Os procedimentos envolviam constantemente a verificação da relação da lista de contrabando - Statutory List, tema abordado na seção 10.1 - incluindo a checagem de navios de bandeira da sueca, russa, norueguesa e holandesa. Até mesmo navios britânicos que chegavam carregados com matérias-primas poderiam estar trabalhando, sem ciência, para os inimigos porque o destinatário final de uma carga poderia ser uma empresa ligada aos alemães. Isto aconteceu com o navio "Cardignashire" que transportava 24.000 barris de cimento dos quais se suspeitava que ao menos 2.400 tivessem empresas pró-germânicas como compradores efetivos, mas que estavam disfarçadas com nomes de empresas de países neutros no manifesto de carga. ${ }^{353} \mathrm{O}$ maior problema para o Departamento Britânico de Comércio da Guerra era quando importações de armas eram autorizadas para o Brasil que as requisitava como parte de

\footnotetext{
351 'German Settlements in Brazil', maio 1916, FO 371/2639/99044, p. 211.

352 'Naval Attaché's Report nr. II', março 1916, FO 371/2639/56657, p. 229-231.

353 Como exemplo de verificação rotineira e detalhada no fluxo de navios no Brasil, ver 'Recent events of naval interest', junho 1916, FO 371/2639 /112206, p. 270-275.
} 
plano de proteção nacional. Estas situações provocavam checagens múltiplas de documentação e de equipamentos, porque desvios de carga eram extremamente prováveis, como ocorreu quando armas foram enviadas pela Mills Equipment Company, empresa que o serviço secreto britânico suspeitava tivesse participação de agente infiltrado do Império Alemão. ${ }^{354}$

A autorização para o envio de armas, carvão, máquinas e equipamentos passou a ser rotina durante a guerra, situação de perda de soberania nacional a qual o governo brasileiro foi forçado a se submeter mesmo na condição de país neutro. A estas autorizações deve ser adicionada toda a relação que o Brasil teve com outros países durante a guerra, fossem assuntos ligados à alimentação, segurança nacional ou movimentação social. Tudo tinha que ser avaliado, catalogado, acompanhado e permitido de acordo com as regras da política internacional da Tríplice Entente, como discutido no capítulo a seguir.

Conclusão

A economia brasileira era dependente de empresários alemães para a comercialização do café nas principais praças do mundo. Esta dependência adiou a decisão do Brasil de declarar guerra à Alemanha. O receio do governo era comprometer negócios com os alemães quando a guerra acabasse. As decisões foram tomadas com muita parcimônia, para não prejudicar as relações nem com o Império Alemão, nem com o Império Britânico.

Os torpedeamentos dos navios brasileiros pela marinha alemã aconteceram como sinal de demonstração do poder da Alemanha. O objetivo era fazer guerra total contra todos os interesses britânicos no mundo e liquidar a guerra em curto espaço de tempo. Estes ataques alemães aos navios brasileiros colocaram em discussão a validade em manter a neutralidade do Brasil. O Brasil era neutro, mas foi atacado pela Alemanha. O Brasil era neutro, mas não recebia a ajuda financeira que gostaria dos países da Entente.

Esta indefinição sobre que lado apoiar na guerra, abriu espaço para a instalação do capital norte-americano no Brasil. Assim como os Estados Unidos, os alemães tinham uma visão pragmática de negócios internacionais. Os dois países construíram alianças no

354 'Export of munitions of war to Brazil and activities of Germano Boetcher of Rio', janeiro 1918, 371/3166/5122, p.325-331. 
mercado internacional visando ao pós-guerra, não importando qual lado sairia vencedor. Este pragmatismo também dominava os negócios do Brasil. Bancos alemães operaram no Brasil livremente durante a maior parte da guerra.

A força do capital alemão no comércio internacional do café manteve ativos os negócios da empresa Theodor Wille no Brasil. Esta empresa continuaria a trabalhar com o Brasil após o fim da guerra. Esta posição do Brasil entre o capital alemão e o capital britânico manteve o Brasil indefinido durante a guerra. É provável que se o Brasil não tivesse sido pressionado pela Entente, o país não teria declarado guerra à Alemanha. As dúvidas sobre que lado da guerra apoiar marcaram os negócios brasileiros durante a guerra, como será apresentado no próximo capítulo. 


\section{Capítulo 9 - A economia brasileira entre as políticas internacionais da Tríplice Entente e da Tríplice Aliança}

A preocupação do Reino Unido em limitar ao máximo a transferência de recursos para a Alemanha limitou os negócios internacionais do Brasil. A Tríplice Aliança e a Tríplice Entente tinham regras diferentes para a economia internacional. O Brasil e a forçado a seguir os países da Aliança. A dívida externa e a necessidade constante de recursos em moeda conversível fizeram o país a acatar as ordens estabelecidas por Londres. A Alemanha comandou a Aliança. O modo de condução das operações internacionais alemãs incluíam montar bases de negócios em países neutros, especialmente na Holanda e nos países escandinavos. O Brasil utilizou estas bases enquanto não foi proibido pelo Reino Unido. Era uma situação de neutralidade apenas aparente.

Com as portas fechadas para negócios com a Alemanha, go governo brasileiro incentivou o Banco do Brasil e o Ministério da Fazenda a buscar alternativas que não significassem desacata às regras da Entente. Foram tentadas operações complexas que envolveram o governo francês. Estas tentativas de negócios eram arriscadas, mas a pressão por soluções para a falta de divisas era o fator preponderante.

O mercado interno brasileiro era de tamanho reduzido. Quando a guerra fechou as principais rotas de negócios internacionais, o Brasil se encontrou em situação de crise constante durante a guerra. Os recursos do funding loan resolveram um problema conjuntural brasileiro, mas o problema estrutural persistia. Os gastos públicos não davam sinal de diminuição. Além de não ter havido nenhuma reforma que reduzisse a demanda por recursos, a guerra impôs novos gastos ao Brasil. Foram gastos ligados ao patrulhamento do litoral brasileiro. Foi um problema difícil de administrar. O país teve que destinar parte de sua frota comercial para controlar um litoral que necessitaria de estrutura muito superior. As invasões de navios alemães foram frequentes.

A situação da economia brasileira seria bastante ruim apenas com as mudanças trazidas pela guerra: bloqueio de rotas marítimas, eliminação de empresas importadoras e exportadoras e falta de crédito. $\mathrm{O}$ elemento que dificultou ainda mais a administração da economia do país durante foi a lista de exceções, programa desenvolvido pelos países da Entente que tinha como objetivo impedir que recursos internacionais entrassem na Alemanha. Este é o tema do próximo capítulo. 
Seção 9.1 - O governo brasileiro e os negócios internacionais no mundo dividido

A Primeira Guerra Mundial exigiu repensar o papel do Estado na economia dos países envolvidos diretamente ou não no conflito. Maior intervenção em aspectos de negócios e da vida cotidiana passou a ser o padrão de atuação do setor público que assumiu o papel de grande consumidor, como verificado na Europa e nos Estados Unidos. De acordo com Yves Guyot, passado o momento inicial de concentração de recursos nas mãos do Estado, a guerra proporcionou alta capacidade transformadora para os países europeus diretamente envolvidos. $^{355}$

As guerras concentram recursos de tal ordem que são necessárias sempre fontes inusitadas para atender à demanda. O Estado é obrigado a retomar soluções, como a cobrança de tributos sobre os mais ricos, que dificilmente teriam viabilidade em tempos de paz. A conjunção de fatores envolvidos em uma guerra levaria a economia a novos patamares, com maior distribuição de riqueza porque o trabalho teria remuneração melhor e o lucro distribuído de maneira mais equitativa. A possibilidade que a guerra traria de criar e destruir riqueza em ciclos muito curtos estaria na base da explicação para encarar as hostilidades entre países de maneira positiva. A renda total na Inglaterra, por exemplo, teria aumentado de $£ 2.400$ milhões em 1913 para $£ 3.000$ milhões em 1916. A grande vicissitude era a indefinição da duração dos conflitos porque, com o tempo, as forças produtivas tenderiam a se esgotar e a destruição de riquezas poderia ultrapassar a capacidade de geração de novos fatores de produção. ${ }^{356}$

Foi precisamente a inquietação sobre o tempo de duração dos conflitos que forçou modificações na política internacional da Tríplice Entente porque duas questões passaram a ser prioritárias em termos de recursos em ouro: contingenciamento e bloqueio. $\mathrm{O}$

\footnotetext{
355 O economista, jornalista e ex-ministro do Trabalho francês, Yves Guyot, foi autor de referência internacional durante a guerra. Guyot já era reconhecido desde a segunda metade do século XIX por suas obras sobre economia e psicologia social. Com o início dos conflitos, ele passou a desenvolver interpretações para avaliar os impactos da guerra de maneira concomitantemente às mudanças econômicas e sociais que se verificavam na Europa. Suas observações se transformaram em um clássico sobre a guerra, "Les causes et les conséquences de la guerre."

Fonte: Assemblée Nationale. Base de données des députés français depouis 1789.

http://www.assemblee-nationale.fr/sycomore/fiche.asp?num_dept=7958

Guyot, "Les causes économiques de la guerre", Les causes et les conséquences de la guerre.

${ }^{356}$ George Pash, Royal Statistical Society. Retrospecto Commercial 1917, p. 5.
} 
contingenciamento era necessário para manter estoques de produtos básicos para a sociedade e para financiar mudanças na produção bélica para as forças armadas. $\mathrm{O}$ bloqueio era destinado a dificultar o acesso ao ouro pelos países da Aliança, muito especialmente o Império Alemão. Para a economia brasileira, estas questões diretamente relacionadas aos países em guerra significaram menor acesso ao ouro do mercado internacional, com consequências para o financiamento do orçamento público, para as exportações e para a geração de renda aduaneira. A escassez de recursos externos fez o câmbio no Brasil adquirir grau de importância ainda maior durante a guerra, com muita discussão sobre a cotação ideal do mil-réis e com a necessidade do uso de licenças de importação, que viraram rotina. O comércio não perdia oportunidade de demonstrar insatisfação com a forma pela qual o governo estava conduzindo a economia em um regime de exceção. ${ }^{357}$

A escassez de ouro forçou o governo brasileiro a negociar as questões inerentes à neutralidade do país na guerra porque as exportações de café foram inicialmente classificadas como contrabando absoluto. No entender da Entente, o café dos países neutros era um produto com alto grau de risco de desvio para os países inimigos que o estocavam para venda no mercado paralelo com elevada margem de lucro. Depois de muitas negociações do Itamaraty, o café passou à condição de contrabando condicional, significando que as exportações seriam examinadas e liberadas por processo. Os problemas no comércio exterior brasileiro não ficaram restritos ao café e até a venda de fumo da Bahia sofreu com as regras para países neutros porque o produto também era considerado foco natural de contrabando. O cacau não recebeu a designação de contrabando e era possibilidade de acesso às divisas internacionais, mas o Brasil perdeu espaço no mercado porque havia a preferência declarada pelo produto de países que declararam guerra aos Impérios Centrais ou pelo cacau proveniente de colônias dos países da Entente. As poucas possibilidades de venda do cacau brasileiro passavam por critérios burocráticos visto que o maior consumidor mundial era a Suíça, mas o país era neutro e tinha as suas compras internacionais controladas pela França. Não bastassem estes entraves, a neutralidade exigiu sacrifícios ainda maiores para a economia brasileira quando a Tríplice Entente passou a preterir os embarques de café e cacau em favor dos carregamentos de trigo e açúcar. A falta de transporte estava em fase aguda e a preferência era para cargas dos países aliados o que afetou em muito o fluxo do comércio exterior para os países neutros. A Tríplice

\footnotetext{
357 'Retrospecto Commercial 1917, p. 3.
} 
Aliança utilizava estes impedimentos na economia internacional para forçar países como o Brasil a rever o posicionamento frente à guerra. ${ }^{358}$

Wenceslau Braz definia assim a neutralidade mantida durante os primeiros anos da guerra: 'neutralidade não é indiferença, mas exprime antes a consciência da nação livre que sabe eleger para si a situação que convém aos seus interesses e ao seu desenvolvimento'. O problema era a dicotomia na qual o país se envolveu porque a neutralidade seguida pelo Brasil era considerada uma declaração de guerra velada aos países da Aliança, mas o país mantinha relações bastante amigáveis com Berlim. As decisões da Entente centralizadas em Londres eram seguidas pelo Brasil de maneira tácita, daí todo o cuidado do governo em não demonstrar germanismo na diplomacia. Esta era a linha dúbia que o Brasil tentou seguir durante a guerra, dando todos os sinais que o país estava disposto a colaborar sumariamente com a Entente, mas ao mesmo tempo demonstrar para o Império Alemão que a neutralidade era consequência de força maior. O Brasil colaborava com as forças dos aliados não por ideologia, mas por falta de opção.

No Palácio do Catete havia muita preocupação com as consequências que as medidas tomadas pelo Brasil durante os conflitos pudessem ter no pós-guerra. Havia expectativa no mercado que a Alemanha voltaria a ocupar lugar de destaque no comércio exterior brasileiro. A hesitação do governo aumentou quando os Estados Unidos entraram na guerra em 1917 e a possibilidade de o Império Alemão ser derrotado foi mais um elemento para Wenceslau Braz considerar as desvantagens do abandono da neutralidade. Do outro lado da balança, foi ponderado que uma declaração de guerra em algum momento de 1917 serviria como plataforma para o país pleitear mais espaço no cenário internacional. $^{359}$

Apesar das indefinições sobre a neutralidade, a questão marítima passou a fornecer os motivos para o Brasil poder obter apoio de Londres nas demandas comerciais e financeiras mais prementes. A vigilância da costa brasileira se tornou fundamental para dificultar que a Alemanha continuasse avançando sobre a 'linha de respeito', como eram conhecidos os limites marítimos. O receio era que os alemães praticassem sua política em águas brasileiras, promovendo saques e ataques que subtraíram grande quantidade de produtos exportados ou importados pelo Brasil. Proteger o litoral do país demandava

\footnotetext{
358 'A guerra europeia e a nossa autonomia'. O Estado de S. Paulo, 29 janeiro 1917, p. 4.

${ }^{359}$ Imparcial, publicado em O Estado de S. Paulo, 24 janeiro 1917, p. 2.
} 
recursos além do orçamento dado que navios brasileiros tinham que ser colocados em atenção total para evitar a invasão de navios alemães, principalmente quando o governo recebia demandas explícitas de controle por parte da Tríplice Entente. Isto demandava recursos que o Brasil tentava conseguir em Londres de maneira extraordinária. ${ }^{360}$

O bloqueio às exportações brasileiras piorou com o racionamento de suprimentos imposto pela Entente aos países escandinavos e à Holanda porque os ataques alemães a estes mercados cresceram e qualquer entrada de navio nos portos da região tinha que ser autorizada. A insatisfação no Brasil com a falta de divisas só aumentava e este sentimento chegou até o Departamento Britânico de Comércio da Guerra. O governo brasileiro insistia que era uma questão especial, que necessitava de solução imediata porque "uma catástrofe se anunciava”. O Brasil propunha o relaxamento do bloqueio ou a compra pela Entente de ao menos parte do café que não podia ser exportado em condições normais. A primeira opção não era sequer aventada pela Entente devido às regras acordadas entre os aliados e que se transformaram em cláusulas pétreas da lista de exceções, Statutory List, tema da seção 10.1. A alternativa levantada sobre a compra do café que não podia ser exportado foi avaliada pela diplomacia britânica que estimou que a operação pudesse envolver a aquisição de até 60.000 toneladas do produto ao custo de $£ 2,5$ milhões. Este valor seria liberado apenas se o Brasil se comprometesse a pagar passivos comerciais com empresas britânicas e a reduzir as tarifas de importação classificando os produtos britânicos como provenientes de 'nação favorecida'. A quantidade que estava em negociação significava algo como 7\% do café exportado pelo Brasil desde o início dos conflitos e ficaria estocada no país para venda no pós-guerra. Na interpretação do corpo diplomático britânico esta seria uma excelente oportunidade para forçar o Brasil a finalmente tomar posse dos navios alemães que estavam nos portos do país. O governo brasileiro acreditava que medida tão extrema seria uma antecipação do ato de declaração de guerra ao Império Alemão, medida para a qual Wenceslau Braz não tinha apoio interno suficiente. Como das outras tentativas do Brasil em viabilizar empréstimos utilizando o café como garantia, a operação não foi aprovada pelo Departamento Britânico de Comércio da Guerra porque a orientação do governo britânico era para que não fossem comprometidos recursos que tivessem por base expectativas econômicas relacionadas ao pós-guerra. ${ }^{361}$

\footnotetext{
${ }^{360}$ Ibidem.

361 'Trade and treaty', novembro 1916, FO 371/2640/231061, p.198.
} 
A falta de alternativas junto ao governo britânico ampliava a crise da escassez de divisas. Para não ficar inerte, o governo autorizou o Ministério da Fazenda a tomar medida absolutamente atípica e desaconselhada nos meios diplomáticos e buscar uma saída diretamente com o governo francês, sem comunicar o fato a Londres. Diante de regras inflexíveis do Departamento Britânico de Comércio da Guerra sobre o comércio internacional, a ideia era tentar alguma brecha que permitisse colocar produtos brasileiros em território francês e de lá promover exportações para outros mercados. Se bem sucedido, este caminho heterodoxo não poderia ser classificado como um ato de provocação à Entente porque teria sido realizado com anuência do governo francês. ${ }^{362}$

O governo britânico tomou conhecimento das intenções do Brasil e emitiu comunicado informando que qualquer entrada não autorizada pelo Departamento Britânico de Comércio da Guerra de produto brasileiro em território francês seria considerada como ruptura de contrato comercial entre o Brasil e o Reino Unido e que um protesto formal chegaria de imediato ao Rio de Janeiro. Londres ameaçou inclusive com a possibilidade de trabalhar a opinião pública dos países aliados contra o Brasil, isolando de vez a economia brasileira. O Reino Unido assumiu neste caso o papel de porta-voz da Entente junto ao Brasil para deixar claro que não seriam admitidas negociações de comércio bilateral que de alguma forma infringissem as regras do Departamento Britânico de Comércio da Guerra. ${ }^{363}$

Ao governo brasileiro restou reafirmar que a situação econômica do país era muito crítica, mas que se as ameaças britânicas fossem levadas a termo o Brasil não se curvaria e aplicaria a cláusula de reciprocidade do comércio internacional dificultando a entrada de produtos dos países da Entente no território brasileiro. Reações de países periféricos enfrentando um poderoso país central eram raras nos meios diplomáticos, o que atraiu a atenção dos agentes econômicos. Londres tinha certeza que ameaças deste tipo acabavam por não se concretizar. Serviam mais para consumo interno do que realmente para considerações pela chancelaria britânica. Apesar desta segurança, os documentos registram que a posição inusitada do Brasil deveria ser administrada. O governo britânico receava que animosidades adicionais poderiam colocar negócios lucrativos do Brasil nas mãos de empresas norte-americanas. ${ }^{364}$

\footnotetext{
${ }^{362}$ Brazilian coffee, dezembro 1916, FO 371/2640/247412, p.242

363 Ibidem, p.243.

364 Ibidem, p.244.
} 
A questão da tonelagem não deveria ter sido motivo tão forte para a diplomacia britânica justificar o bloqueio das exportações a partir do Brasil porque a quantidade de carga que passou a ser transportada durante a guerra aumentou consideravelmente. $O$ fluxo maior de mercadorias foi resultado de medidas que a Entente estabeleceu de estoques de produtos essenciais e que alterou completamente a ocupação dos navios que passaram a transportar trigo, carne congelada ou em lata, em volumes muito acima da média anterior ao início das hostilidades. Foram colocados à disposição dos aliados 328 navios, regulares e tramps - navios sem rota fixa, contratados por demanda - que passaram a ter suas tonelagens administradas pelo Comitê de Controle de Embarques (Shipping Control Committee) em Londres. As operações eram centralizadas no Comitê que passou a negociar fretes no atacado, obtendo descontos e garantindo espaço nas embarcações. Estas vantagens eram inacessíveis aos países neutros que foram obrigados a fretar os espaços que porventura sobrassem nestes navios diretamente com os agentes de carga, sem desconto.

O modo de ação do Comitê de Controle de Embarques variava conforme o produto ou o destino. Nos casos dos embarques de trigo e carne para os portos aliados, o Comitê interferia para que os preços praticados fossem mais baixos que a média do mercado. A exceção ficava para o trigo destinado à Itália. Neste caso, o produto deveria ser exportado pela Austrália, o que acarretava frete maior que o despendido pelos outros aliados. Se a Itália necessitasse de quantidade superior de trigo, a fonte poderia ser os Estados Unidos, mas com cobrança de adicional de frete. O trigo australiano poderia entrar no mercado internacional sempre que o fornecimento dos Estados Unidos sofresse redução por qualquer motivo. Nestes casos, os fretes seriam administrados separadamente, de acordo com a demanda do Comissão Real para o Suprimento de Trigo (Royal Commission of Wheat Supplies) que estipulou que o trigo argentino seria destinado preferencialmente à França e ao Reino Unido. A Comissão estabelecia as rotas dos produtos essenciais de acordo com o risco que os submarinos alemães causavam e estipulava que grandes carregamentos de carne da Argentina, que supria metade do consumo dos países da Entente, deveriam ser fracionados para reduzir as perdas por naufrágio ou desvio dos produtos. $^{365}$ Neste mundo em guerra, os embarques de trigo e carne tinham prioridade, beneficiando o comércio exterior argentino. Por esta lógica de grau de essencialidade, o café brasileiro tinha que travar uma batalha que já nascia perdida porque o produto era

\footnotetext{
365 'Tonnage for the new wheat programm / cased meats', novembro 1916, MT 23/741/T98270, T92661,
} T93917, memorandum and minute. 
considerado supérfluo e com grande capacidade de ser utilizado como reserva de valor. Como o risco de contrabando de café era elevado, o produto era sistematicamente rejeitado pelo Comitê de Controle de Embarques e o Brasil ficava privado de sua mais importante fonte de divisas.

\section{Seção 9.2 - Neutralidade disfarçada e os negócios internacionais}

A política internacional da Entente causava muitas dificuldades ao comércio exterior brasileiro, restringindo as opções de acesso ao crédito internacional e expondo o precipício financeiro para onde se encaminhava. O segundo semestre de 1917 se aproximava e isto marcaria o retorno de desembolsos relacionados à dívida externa de acordo com contrato assinado no funding loan. Os elementos que compunham as preocupações do Brasil foram abordados por Wenceslau Braz durante reunião com representantes do comércio, indústria e do comércio, encontro que contou com a participação do adido britânico no Rio de Janeiro. Arthur Peel relatou a maneira sem reservas que o Presidente utilizou para falar sobre o grande desafio que seria para o país cumprir o acordado no funding porque as cifras somadas totalizavam algo como $£ 750 \mathrm{mil}$ somente em juros, valor acima das possibilidades do país mesmo em tempo de paz. Ficou patente no relato de Peel que o Brasil não havia se preparado para voltar a pagar os serviços da dívida e que país não tinha condições de continuar honrando sequer os compromissos atuais, em moeda nacional e em ouro. Alguma medida teria que ser adotada para preservar o funcionamento da economia brasileira. ${ }^{366}$

A impossibilidade de obtenção de recursos no exterior era quase absoluta. Os apelos do governo junto ao sistema financeiro internacional não resultavam em soluções. Diante deste cenário, a proposta que Wenceslau Braz levou para um encontro especial com empresários foi a de criação de uma taxa especial que garantisse a formação de um novo fundo de reservas. Os recursos não seriam suficientes para honrar todos os compromissos no exterior, mas este novo tributo seria uma espécie de "taxa de honra" e deveria ser cobrado de empresas que estavam conseguindo obter margens expressivas de lucro apesar do contexto de adversidade. Arthur Peel, representante britânico no encontro em questão, assegurou para o seu governo que as intenções do presidente pareciam convergir no sentido de um compromisso verdadeiro para com as obrigações brasileiras no exterior, mas ele não acreditava na eficácia de um novo tributo no Brasil. Justificou sua descrença

\footnotetext{
366 'Political', junho 1916, FO 371/2640/125721, p. 32.
} 
utilizando como exemplo os direitos aduaneiros cobrados em Santos. Antes de a incumbência pela cobrança dos tributos sobre as importações passar para a Companhia Docas, o Estado nunca havia conseguido arrecadar mais do que $£ 550$ mil, mas após as reformas empreendidas, o valor passou para $£ 1.100$ mil e, alguns meses depois, atingiram $£ 2.200$ mil. $^{367}$

Situação semelhante poderia ser verificada no conjunto das estradas de ferro que quando administradas pelo Estado proporcionavam retorno menor sobre o capital investido em comparação ao que ocorria quando uma companhia ferroviária era administrada por uma empresa privada. Peel afirmou que este novo tributo teria como alvo empresas com lucro elevado, precisamente o caso das empresas de capital estrangeiro porque estas operavam em bases mais sólidas que suas congêneres brasileiras. ${ }^{368}$ As considerações do diplomata britânico tinham o propósito de sensibilizar o seu governo para o fato de que a culpa para os infortúnios da economia brasileira poderia ser encontrada na forma como os recursos eram administrados no Brasil e não nas consequências da política da Tríplice Entente para o comércio internacional.

A política internacional da Entente exigia ações para os quais o Brasil estava despreparado. Havia carência de embarcações para o transporte de cabotagem e faltavam meios para levar os produtos brasileiros para o exterior. Como efeito colateral, o custo para sustentar os navios que tentavam guardar o litoral do país era demasiado elevado quando considerada a quantidade de carvão utilizado como combustível. Vale lembrar que os navios consumiam carvão importado que estava com preço elevado, preço que refletia a escassez própria da guerra. Para seguir as diretrizes da Entente, foi criada a 'Liga Brasileira pelos Aliados' que tinha por propósito a defesa do território brasileiro das investidas de navios alemães. O ponto mais vulnerável para a defesa marítima nacional era o litoral do Rio Grande do Norte, área onde embarcações estrangeiras passaram a fazer manobras com intensidade crescente durante a guerra. ${ }^{369}$

Não havia muito que a Liga pudesse fazer para atender aos planos estipulados pela Entente porque a falta de recursos era latente, mas foram estipulados movimentos que a Marinha deveria executar para mostrar que havia proteção do litoral do nordeste brasileiro. Navios e cruzadores em pequeno número faziam exercícios de logística complexa que

\footnotetext{
367 “Political”, junho 1916, FO 371/2640/125721, p. 30-1.

${ }^{368}$ Ibidem.

369 'Quanto custa a vigilância do litoral brasileiro?' O Estado de S. Paulo, 28 janeiro1917, p. 3.
} 
envolvia a substituição de naves e a montagem de roteiros alternativos, alcançando ilhas e localidades que não eram normalmente patrulhadas. A preocupação final não era garantir a segurança nacional, mas expressar a defesa da neutralidade brasileira junto à Entente. ${ }^{370}$ Para não causar problemas com a Tríplice Aliança, havia o cuidado em não desrespeitar as regras impostas aos países neutros e que incluíam o acompanhamento dos navios que transportavam malotes. Estas embarcações eram especiais e tinham estadia determinada em algumas horas, o suficiente para as operações de atracação, descarga e partida. Como na maioria dos casos estes barcos tinham bandeira de países da Entente, chegava a ser curioso ver a Marinha do Brasil patrulhando naus com bandeira britânica, por exemplo. ${ }^{371}$

Se o Brasil tinha este tipo de cuidado em relação ao Império Alemão, a recíproca não se verificava. Na prática, a Alemanha impunha bloqueio naval ao Brasil e até mesmo navios de outros países neutros como a Noruega, contratados para fazer a rota entre portos brasileiros e portos dos Estados Unidos, sofriam ataques dos alemães. Empresários no Brasil protestavam porque o mesmo tipo de tratamento não era dispensado aos Estados Unidos quando praticavam comércio exterior com países neutros. O Império Alemão concedia desde o início da guerra tratamento diferenciado ao comércio com bandeira norteamericana porque interesses econômicos faziam com que a guerra tivesse impacto menor para os negócios entre os dois países. ${ }^{372}$ Esta desigualdade de reação dos alemães pode ter influenciado países neutros a tentar manter relações comerciais com a Tríplice Aliança como salvaguarda no comércio internacional.

A neutralidade brasileira era vista como passiva, algo que feria o brio nacional. Críticos diziam que tudo não passava de uma grande encenação, como no caso da defesa do litoral brasileiro contra navios alemães que não respeitavam as três milhas náuticas de águas brasileiras e que deveriam ser abatidos pela Marinha do Brasil. O problema era como garantir o respeito a esta determinação quando era notório que as embarcações do Império Alemão eram invariavelmente mais velozes que qualquer navio da frota brasileira. Os relatos de invasão do Brasil eram inúmeros e acreditava-se que a situação estava fora de controle porque a precariedade da defesa brasileira permitia que até mesmo pontos do litoral fossem alcançados pelos barcos estrangeiros sem que as autoridades brasileiras se dessem conta.

\footnotetext{
${ }^{370}$ O Estado de S. Paulo, 06 janeiro 1917, p. 6; O Estado de S. Paulo, 21 janeiro 1917, p. 3.

371 'S. S. Edimburg Castle'. O Estado de S. Paulo, 22 janeiro 1917, p. 1.

${ }^{372}$ O Estado de S. Paulo, 21 janeiro 1917, p. 4.
} 
As estimavas de gastos com a neutralidade eram de aproximadamente cem contos de réis/dia, equivalente a $£$ 6.000/dia. Era um gasto elevado demais com o único objetivo de manter a cordialidade perante os dois lados da guerra. A contrapartida da Aliança era interpretada pela sociedade brasileira como extremamente descabida porque a Alemanha sufocava as finanças do Brasil ao bloquear o comércio exterior do país com os seus submarinos. Do lado da Entente, a restrição às exportações dos poucos produtos que poderiam trazer divisas para o mercado nacional deixava o governo brasileiro aparentemente inerte diante da situação. Muito da indefinição no Brasil quanto a que lado apoiar na guerra teve relação com as consequências que o conflito trazia para a economia nacional. Aos olhos da sociedade, não fazia muita diferença perfilar com os países da Entente ou da Aliança.

O debate passou a girar em torno do abandono definitivo da neutralidade disfarçada porque os sinais que o Brasil emitia para o mundo eram confusos. A Entente respeitava a neutralidade brasileira, mas exigia que o país praticasse o bloqueio efetivo das embarcações alemãs nos portos nacionais. Os países da Aliança não permitiam o comércio do Brasil com os países neutros ou com os da Aliança. ${ }^{373} \mathrm{O}$ que o governo brasileiro tinha que ponderar era o risco de manter a neutralidade com deveres de país beligerante, mas sem direitos compensatórios. Era uma espécie de neutralidade modelar porque envolvia atitude de renúncia assumida por nação que se declarava neutra e que deveria abandonar de maneira sistemática os próprios interesses para atender interesses dos países em guerra. A situação chegara a tal ponto que o Reino Unido receava que a continuidade da pressão desponderada que a Aliança exercia sobre o governo brasileiro pudesse levar o país para acordos com a Alemanha.

O receio dos britânicos não era infundado. Havia um sentimento importante próAlemanha na sociedade brasileira que poderia ganhar proporções ainda maiores caso não fossem encontradas saídas para a crise que paralisava os negócios. Esta situação chegou a mobilizar o governo brasileiro para atacar a germanofilia que emanava de vários formadores de opinião, geralmente de empresários interessados na preservação ou na retomada dos contratos comerciais com a Alemanha. Quando se considera a relevância que o capital alemão tivera para os negócios do café até 1913, não era de se espantar a legião de defensores que os empresários teutos tinham no Brasil. As operações internacionais do

\footnotetext{
${ }^{373}$ O Estado de S. Paulo, 02 janeiro 1917, p. 3.
} 
café funcionaram a contento até o início da guerra e a possibilidade de substituir Hamburgo como o maior destino das exportações brasileiras tinha implicações que excediam a simples questão logística. $\mathrm{O}$ que se discutia era a validade em desmontar um sistema que dificilmente traria os mesmos benefícios à economia cafeeira instalada no Brasil.

Este sentimento a favor do Império Alemão foi testado em vários momentos. A invasão da Bélgica pelos países da Aliança forneceu durante os primeiros anos da guerra os fundamentos para a revisão da questão da neutralidade. Para alguns países o ato foi a violação pura e simples de um tratado. Outras nações acreditavam que a questão belga deveria ser interpretada como violação à convenção de Haia. A diferença era que um tratado rompido teria que significar declaração de guerra como ato contínuo, já o desrespeito à Haia justificaria, no máximo, o rompimento de relações diplomáticas. O Brasil simplesmente se ateve aos discursos nos foros internacionais da guerra criticando a ação da Aliança. Internamente, o governo dizia que faltavam elementos que permitissem ao governo um caminho mais vantajoso no pós-guerra e até mesmo a invasão da Bélgica teria que ser analisada de acordo com o pragmatismo dos negócios. Este cuidado em não prejudicar o futuro dos negócios não foi invenção brasileira. Os países da Entente agiam na guerra com patriotismo eloquente, mas havia a certeza que o armistício traria a retomada dos negócios. Adotar muita força nas declarações contra um país durante a guerra poderia implicar em perdas colossais no processo que adviria para a recuperação das combalidas finanças dos países beligerantes. ${ }^{374}$

Outro momento crucial para as relações internacionais do Brasil durante a guerra foi o rompimento das relações diplomáticas dos Estados Unidos com a Alemanha, em abril de 1917. O anúncio oficial se deu com discurso do presidente Woodrow Wilson que declarou que esperava que todas as nações neutras seguissem o mesmo caminho e rompessem relações com o Império Alemão. Um convite dos Estados Unidos em 1917 já era interpretado como pressão em termos econômicos: os países que apoiassem a iniciativa americana teriam portas abertas para o maior mercado do mundo em termos financeiros e de comércio. Ainda não estavam patentes os sinais de declínio do Reino Unido, mas empresários em todos os países eram conhecedores das vantagens em fazer negócios com a

${ }^{374}$ O Estado de S. Paulo, 04 fevereiro 1917, p. 2. 
próspera nação americana. A pressão para mudanças nas relações internacionais do Brasil atingira o ponto máximo desde $1914 .{ }^{375}$

Na opinião de estrategistas militares e econômicos, a declaração de guerra dos Estados Unidos esvaziara a defesa da neutralidade em todos os territórios. Até mesmo países notoriamente neutros como Suíça, Dinamarca e Holanda deveriam aproveitar o caminho aberto por Washington e declarar guerra à Alemanha porque os suprimentos que abasteciam as tropas da Aliança chegavam por intermédio destes países. O problema seria como estas nações conseguiriam enfrentar o poder alemão antes da chegada dos reforços militares norte-americanos à Europa. ${ }^{376}$ Este receio do que a Alemanha ainda era capaz de fazer impediu uma avalanche de declarações de guerra contra os países da Aliança.

Naturalmente, a neutralidade brasileira passou a ser muito debatida a partir da declaração de guerra dos Estados Unidos. Até então, a posição oficial do país era vista como uma saída política que buscava a harmonia com as outras nações americanas, essencialmente com Washington. Contra o senso comum, a mudança de postura dos Estados Unidos não alterou de maneira radical a posição brasileira. O Brasil não aproveitou a mudança estabelecida no movimento diplomático norte-americano para mudar de postura frente à Tríplice Aliança. Ainda seriam necessárias alterações de outra ordem na política internacional para que o país adotasse esta medida. ${ }^{377} \mathrm{O}$ receio no Brasil era compartilhado pelas outras nações latinas que temiam mudanças que prejudicassem suas exportações no pós-guerra. Manter a neutralidade significava preservar possibilidades de negócios futuros com a Alemanha. Declarar guerra à Aliança seria assentir no papel dos Estados Unidos como novos líderes globais, com novas regras para a economia internacional. A movimentação diplomática foi intensa na região, com a Argentina se solidarizando formalmente com os Estados Unidos e até indicando que poderiam tomar atitude mais drástica como o rompimento de relações com a Aliança. Ponderações feitas, Buenos Aires decidiu manter a neutralidade e não adotar nenhuma medida contra os países da Aliança. ${ }^{378}$

O Brasil também hesitava. Ato contínuo à pressão dos Estados Unidos, o governo brasileiro decidiu manter a posição de neutralidade e fez manifestação expressa neste

\footnotetext{
${ }^{375}$ Sobre a economia dos Estados Unidos durante a Primeira Guerra Mundial, ver: Rockoff, Until it's over, over there: The U. S. economy in World War I.

${ }^{376}$ O Estado de S. Paulo, 06 fevereiro 1917, p. 1.

377 O Estado de S. Paulo, 12 fevereiro 1917, p. 4.

${ }^{378}$ O Estado de S. Paulo, 11 abril 1917, p.2.
} 
sentido ao governo imperial alemão em fevereiro de 1917. Foi uma ação sem sentido prático, porque a atitude norte-americana promoveu o bloqueio do tráfego marítimo internacional. Do lado alemão aumentavam os torpedeamentos a embarcações comerciais de diversos países. A situação só fazia piorar. Nesta carta ao governo alemão, o Brasil manifestou críticas à situação de asfixia no comércio internacional, mas deixou claro que não tomaria medidas de outra ordem frente ao problema nas águas internacionais. Em tom no qual se percebe o cuidado em não melindrar Berlim, o documento explicita o desejo de liberdade comercial e responsabiliza a Alemanha por perdas de vidas e de bens materiais que os ataques alemães provocavam. A resposta alemã ao endurecimento dos discursos da Entente e dos países que acompanharam os Estados Unidos foi informar que a guerra submarina entraria em fase sem restrições: navios beligerantes e neutros seriam torpedeados e bombardeados indistintamente. A hesitação brasileira chegara ao fim. ${ }^{379}$

O torpedeamento do navio N.M. Paraná em 05 de abril de 1917 na baía do Sena foi interpretado no Brasil como sinal de algo maior, mais grave, espécie de ultimato do Império Alemão para o país abandonar a neutralidade porque o navio foi atingido com cinco tiros de canhão, com a clara intenção de afundá-lo. $\mathrm{O}$ ataque causou a morte de um marinheiro e ferimentos em outros três. ${ }^{380}$ Vale lembrar que este era o melhor navio mercantil à disposição do comércio exterior brasileiro e estava alocado na Companhia de Comércio e Navegação.

Após o naufrágio do navio Paraná, ações mais enérgicas eram esperadas do presidente brasileiro, mas estas não viriam antes do encerramento de relatório oficial que estava em preparação na delegação diplomática brasileira em Paris. Sobre o caso, o governo alemão alegou que a embarcação brasileira afundou porque se chocou com uma mina francesa. O Brasil não aceitou a defesa alemã e protestou de maneira mais veemente, angariando manifestações de países europeus que congratularam o governo brasileiro por ter tido destaque na política internacional em atos contra as violações de neutralidade praticadas pela Alemanha. ${ }^{381}$ Empresários estrangeiros estabelecidos no Brasil começaram a fazer chegar às suas representações diplomáticas solicitações de planos em caso de

\footnotetext{
379 O Estado de S. Paulo, 12 fevereiro 1917, p. 3.

${ }^{380}$ Revista da Escola de Guerra Naval. Rio de Janeiro, no 14, 2009, 'Política Externa e Defesa na Primeira Metade do Século XX', p. 25-50

${ }^{381}$ O Estado de S. Paulo, 19 abril 1917, p. 1.
} 
declaração de guerra, algo que parecia impossível de ser postergado tamanha era a pressão social. $^{382}$

Internamente, a animosidade da sociedade para com o Império Alemão foi insuflada por formadores de opinião em diversos momentos, como o que fez Sá Vianna, professor da Faculdade de Ciências Sociais do Rio de Janeiro, em carta a Wenceslau Braz no início de 1917. No documento, além de rememorar os casos de navios brasileiros levados a pique por forças alemãs, Vianna destacou a venda do café brasileiro que estava estocado em Hamburgo com registro de preço aceitável, "dadas as condições impostas pela guerra". O problema foi o desfecho lamentável do caso porque o elevado valor obtido nesta transação ficou retido no banco Bleischröder de Berlim em situação que o mercado considerada como perdida. Dificilmente o governo brasileiro teria acesso ao valor depositado em seu nome antes do fim da guerra. Não fazia sentido manter relações com uma nação que tantos prejuízos causava à economia brasileira. ${ }^{383}$

O aviso do rompimento de relações diplomáticas com Império Alemão se deu em mensagem de 3 de maio de 1917 na qual Wenceslau Braz informou que o ato era consequência do torpedeamento do NM Paraná. Os arquivos dos documentos da delegação brasileira em Berlim ficariam a cargo do Governo Suíço que passaria a responsável na intermediação das transações relacionadas ao café brasileiro que restavam pendentes em Berlim. Depois que os Estados Unidos entraram na guerra, a frase de Roosevelt dominou as discussões sobre a neutralidade: 'Ninguém pode ser neutro em uma guerra com esta, na qual os princípios básicos da democracia estão em jogo'. Antes de o Brasil se preparar para efetivamente entrar na guerra, o país deveria se preparar para as represálias do Império Alemão naturalmente adviriam após o ato de declaração de guerra. ${ }^{384}$

O fim da neutralidade brasileira era explicado por afinidades inclusive de raça para com as nações da Entente, por questões morais, de liberdade de desígnio de cada nação, dentre tantos outros planos de análise, mas o elemento decisivo foram as transações comerciais e os excedentes na balança comercial, principalmente com os Estados Unidos. Contribuiu sobremaneira o fato de o comércio com a Entente ter permanecido aberto, apesar de controlado, ao passo que o intercâmbio com os países da Aliança ter se

\footnotetext{
${ }^{382}$ Coleção Wileman - 'The Brazilian Review', 10 abril 1917, p. 269.

${ }^{383} \mathrm{O}$ total negociado foi de 1.400 sacas de café, sendo metade proveniente de Hamburgo e metade de Antuérpia, com juros que seriam acumulados até o final da guerra. 'Chegada do Sr. Oscar Teffé - A vida em Berlim e na França'. O Estado de S. Paulo, 03 fevereiro 1917, p. 2.

${ }^{384}$ Coleção Wileman - 'The Brazilian Review', 17 abril 1917, p. 287.
} 
paralisado. Para os países neutros em áreas de influência da Entente, passou a ser uma operação muito complexa manter algum tipo de comércio com a Alemanha.

Quando do armistício, empresários brasileiros queriam crer que seria tarefa fácil fazer o povo alemão compreender a atitude brasileira contra a Aliança. O Brasil não tivera opção naquele contexto. Até mesmo os navios do Império Alemão arrestados nos portos brasileiros o foram seguindo o princípio de quebra da neutralidade, quando cessaram os direitos de propriedade privada e passaram a vigorar os direitos dos Estados. Deixaram de ser navios pertencentes a empresas de capital privado com sede na Alemanha e passaram a ser bens classificados como de propriedade do Estado Alemão. As circunstâncias da guerra cessando, as relações comerciais poderiam voltar à normalidade. ${ }^{385}$

O naufrágio do navio 'Macau', torpedeado por submarino alemão em 25 de outubro de 1917, já seria fato de extrema relevância para a alteração do status das relações do Brasil para com a Alemanha, mas o ponto que realmente provocou a mudança na diplomacia brasileira foi a prisão do capitão do Macau. Não havia mais como remediar e a declaração de guerra aos países da Tríplice Aliança foi tornada pública por meio do Decreto $\mathrm{n}^{\mathrm{o}} 3.311$ assinado às $18 \mathrm{~h} 26$ do dia 26 de outubro de $1917 .{ }^{386}$ Apesar do clima favorável à decisão do governo, o Congresso ainda debateu a questão porque o Deputado Federal Joaquim Pires levantou a polêmica sobre a constitucionalidade do ato de declaração de guerra. A Constituição previa a situação de guerra declarada em duas circunstâncias para as quais o governo teria autonomia:

a) Invasão do território nacional;

b) Ameaça à soberania nacional.

$\mathrm{Na}$ interpretação do deputado, o naufrágio de navios mercantis não se enquadrava em nenhuma das duas premissas e não deveria ter sido evocado como motivo para a declaração de guerra sem consulta formal ao Congresso.

Os navios 'Acary' e 'Guayba', torpedeados logo após a declaração de guerra, foram motivo para as sanções contra interesses econômicos da Alemanha no Brasil como a suspensão de direitos sobre bens privados, impedindo a venda de propriedades ou mesmo a comercialização de produtos alemães. Foram ainda declarados sem efeito contratos de

\footnotetext{
${ }^{385}$ O Estado de S. Paulo, 24 outubro 1917, p. 9.

${ }^{386}$ Ver, "War", Coleção Wileman, 30 outubro 1917, p. 367.
} 
compra e venda de terras e propriedades. O ponto mais grave foi a ameaça do governo em cassar a autorização para o funcionamento de bancos e casas de comércio exterior que tivessem capital alemão em suas composições. As casas comerciais e os estabelecimentos bancários poderiam ter suas licenças cassadas, 'conforme as circunstâncias' ${ }^{387}$ Seria um ato que coadunaria com a declaração de guerra, mas as implicações práticas desta ação deram às ameaças um tom de bravata.

Apesar do discurso inflamado contra o Império Alemão, os interesses econômicos alemães no Brasil acabaram sendo preservados. Os três bancos alemães em operação no país não foram fechados e nem sequer tiveram suas atividades suspensas. A única medida cautelar foi que as instituições passaram a ter que funcionar por um determinado período com a presença de fiscais do Ministério da Fazenda. Os técnicos não chegaram a assumir a direção dos estabelecimentos, apenas controlavam as operações para evitar negócios que fossem 'contrárias às leis de guerra ou que trouxessem inconvenientes' ao Brasil ou aos países aliados.

O Brasilianische Bank era o banco alemão mais antigo a operar no Brasil, com autorização válida desde 7 de setembro de 1888. O banco era filiado ao Disconto Gesellschaften de Berlin e operava com agências na Bahia, São Paulo e no Rio Grande do Sul. Já o Banco Alemão Transatlântico estava no Brasil desde julho de 1911 e o Banco Germânico da América do Sul desde maio de 1911. A liquidação propriamente dita destes três bancos não poderia ser executada pari passu ao ato de declaração de guerra porque os impactos no comércio não compensariam atender à logica do estado de guerra.

A situação destes bancos ficou insustentável somente após pressão da Tríplice Entente ocorrida em julho de $1918 .{ }^{388}$ Por meio do Decreto ${ }^{\circ} 13.235$ de 16 de outubro de 1918, os bancos Deutsch-Südamerikanische e Deutsche Übersee tiveram licenças cassadas e receberam seis meses de prazo, prorrogáveis por mais seis meses, para liquidar suas operações no Brasil. O Brasilianische Bank für Deutschland não teve autorização renovada e também deveria sair do país no mesmo prazo que os congêneres. Não demoraria muito para que estas decisões mais drásticas fossem revistas. Na Alemanha, as operações dos três bancos no Brasil já eram consideradas como sobrepostas, com as instituições disputando o mesmo mercado. Somando esta constatação ao aumento do grau de concorrência que as

\footnotetext{
${ }^{387}$ Mensagem Presidencial 1918, p. 10.

${ }^{388}$ Relatório Ministerial da Fazenda - 1918, p. 83.
} 
matrizes destes enfrentavam na Europa, foi uma questão de tempo para que o Brasil fosse ocupado por apenas uma destas organizações financeiras. $\mathrm{O}$ banco escolhido foi o Alemão Transatlântico que logo em 1919 retomou operações no Rio de Janeiro. ${ }^{389}$

Apesar dos temores que ainda pairavam nos negócios internacionais do Brasil, Wenceslau Braz passou a receber apoio inédito após a declaração de guerra à Alemanha. $\mathrm{O}$ país não poderia mais sustentar sua posição de neutralidade depois da identificação cada vez maior dos ideais dos Aliados e dos ataques da Marina Imperial da Alemanha aos navios brasileiros. A fase foi tão positiva para o presidente que a sua mensagem de 1917 sobre o país estar em período de "franca convalescença" foi respaldada pelos principais órgãos de imprensa. Os jornais diziam que doutrina Monroe havia sido interiorizada e que o país não poderia mesmo permanecer neutro, insensível às questões mais caras aos Estados Unidos e à Europa. A leitura destes periódicos indica uma clara guinada de simpatia em relação aos norte-americanos.

Soluções bem sucedidas nos Estados Unidos passaram a fazer parte do receituário contido na política econômica do governo. Exemplo indicativo foi o Comitê de Produção Nacional, uma versão do Comitê de Defesa Nacional dos Estados Unidos, que previa uma coordenação mais eficaz da produção nacional, uma espécie de pacto nacional para enfrentar o período de guerra. $\mathrm{O}$ alcance que esta medida teve no Brasil não pode ser comparado ao que ocorreu nos Estados Unidos, mas indica a aproximação entre as duas nações e ainda uma gradual desaceleração nas relações internacionais do Brasil com a Europa. $^{390}$

Este afastamento do Brasil em relação aos tradicionais parceiros europeus, muito especialmente no que afetava ao Reino Unido, foi sistematizado durante a vigência das regras de exceção no comércio internacional. Este foi o período das statutory lists, mecanismo de defesa dos países da Aliança que tinha como objetivo abreviar a guerra por meio da dificultação da entrada de recursos na Alemanha. Londres foi a base intelectual e burocrática destas listas de exceções que obrigaram o governo brasileiro a modificar a política econômica do país. Os caminhos que o Brasil percorreu para encontrar soluções que permitissem alguma atividade econômica nos setores interno e externo, em cenário de exceção inédita no comércio internacional, são o tema do próximo capítulo.

\footnotetext{
389 'Historischen Gesellschaft der Deutschen Bank e.V.' Frankfurt am Main, setembro 2012.

${ }^{390}$ Retrospecto Commercial 1917, p. 10.
} 
Conclusão

A guerra aumentou a discussão no Brasil sobre qual deveria ser o papel do Estado na economia. Apesar do receio de alguns empresários, teria sido impossível desenvolver atividades econômicas no Brasil se o governo brasileiro não tivesse tomado iniciativas e participado ativamente dos mais diversos aspectos da economia internacional. Situação análoga acontecia no Reino Unido. Seria inconcebível enfrentar a guerra em termos econômicos sema ampliação dos poderes do Estado.

O governo brasileiro administrou a neutralidade com a intenção de manter laços comerciais com os dois lados da guerra. Sendo neutro, o Brasil ser atacado pelo Império Alemão. A lógica que explica os torpedeamentos dos navios brasileiros é simples: a Alemanha estava ciente que o Brasil não poderia abandonar a sua ligação com o Reino Unido. A dívida externa brasileira administrada por Londres ditava regras ao governo brasileiro. Houve muita ingerência dos britânicos nos negócios internos do Brasil.

Entre a Entente e a Aliança, a disposição do Brasil era manter ligações com os dois blocos. Após ter tido alguns navios naufragados por forças alemãs, o Brasil ainda tentou evitar a declaração de guerra que colocaria o país como o único país da América Latina a enviar força para a guerra. Se não foi possível evitar a guerra, os negócios com os alemães poderiam ser mantidos. Durante quase todo o período dos conflitos, importantes bancos alemães mantiveram operações no Brasil. Estas operações davam aval e crédito para outros negócios, demonstrando a força dos interesses financeiros sobre as discussões ideológicas. Estes negócios tiveram que ser adaptados após o início da statutory list, as listas de exceções no comércio internacional que tanta influência teve sobre a economia brasileira durante guerra. Este é assunto do próximo capítulo.

\section{Capítulo 10 - Comércio exterior em regime de exceção}


A statutory list, ou lista de exceção, foi um mecanismo de controle implantado pelo Reino Unido, com anuência dos países da Entente. O objetivo era impedir que o Império Alemão tivesse acesso a recursos conversíveis. O receio dos britânicos era que a Alemanha utilizasse recursos extraordinários para ampliar o seu poder bélico. As regras das listas de exceções eram complexas. Uma empresa dos países da Entente ou de países neutros suspeita de ter algum tipo de atividade com o capital alemão poderia entrar para a lista ou não. Tudo dependia de uma série de exigências e graus de contágio com os negócios alemães.

No Brasil, a statutory list relacionou dezenas de empresas que aparentemente eram de capital brasileiro, mas que os especialistas em Londres comprovavam que tinham ligação com empresas alemãs. Estes casos foram abundantes no comércio exterior brasileiro, especialmente nos relacionados ao café e à borracha. No Amazonas, a lista de exceções classificou importantes agentes de exportação como agindo em interesse dos inimigos.

No Sul do Brasil, dada a profusão de empresas que tinham sócios ligados de alguma maneira ao Império Alemão, a statutory list incluiu estabelecimentos em áreas tão diversas quanto navegação, metalurgia, química e carvão. Agentes de carga entraram para a lista de exceções. O poder da statutory list fez com empresas alterassem a razão social ou que se disfarçassem como empresas de outros países neutros.

Comércio exterior em regime de exceção.

Seção 10.1 - Statutory List: estrutura e impactos da lista de exceções na economia brasileira

Statutory List foi o termo utilizado pelo Reino Unido e seus aliados durante a guerra para classificar pessoas e empresas de origem germânica, essencialmente de nacionalidade alemã, com as quais empresas e cidadãos britânicos passaram a ser proibidos de comercializar. Na prática, ter o nome na lista de exceção inviabilizava a participação no comércio internacional porque os bancos e os armadores britânicos concentravam as operações globais de comércio exterior e passaram a rejeitar cargas que tivessem como proprietários ou destinatários nomes constantes das muitas listagens que circularam pelo mundo, consubstanciação do Ato 'Negociando com o Inimigo - Extensão de Poderes' de 
1915. Durante este período, o termo Black List ficou restrito aos casos tradicionais de segurança nacional, sem relação direta com o conflito mundial e que, por isto, não teriam os nomes de pessoas e empresas revelados. O Departamento de Comércio Exterior do Reino Unido foi reestruturado em janeiro de 1916 e passou a ter como função precípua administrar a lista de exceção, dificultando em muito que recursos dos países aliados ou de países neutros fossem incorporados pelas potências centrais. ${ }^{391}$

Montar e atualizar a lista de exceções exigiu esforços e recursos que o governo britânico não previra. Os meios que permitiam às empresas alemãs canalizar recursos para o Império se multiplicaram durante a guerra e eram de difícil rastreamento. Isto obrigava o Departamento de Comércio da Guerra a travar verdadeira guerra burocrática nas relações internacionais, levando ao Brasil novos procedimentos para exportações e importações com grande impacto na macroeconomia do país. Documentos secretos do governo britânico demonstram como foi árduo o trabalho de classificação dentro da lista de exceções e como estas novas regras tinham potencial para efetivamente travar as operações na economia internacional. Os novos parâmetros trazidos pela prática da lista de exceção seguiam, resumidamente, a seguinte diretriz, replicável para todas as unidades diplomáticas britânicas no mundo:

\section{(1) Importações}

Todos os processos de importação, depois de análise pela alfândega e das considerações do Departamento de Comércio do Reino Unido, poderiam ter:

a) Liberação do produto, se comprovada origem legítima de países aliados ou neutros, ou se a importação tivesse sido amparada por licença de importação;

b) Detenção do bem, até conclusão das análises dos especialistas do governo britânico;

c) Liberação, mas com pendência para a produção de provas. O Departamento de Comércio Britânico, em documentação interna restrita, especifica que, para estes casos, seriam utilizados métodos alternativos, como a censura de documentos e cartas dos envolvidos no negócio.

(2) Exportações

\footnotetext{
${ }^{391}$ FO 833/16/10618, janeiro 1916, "Statutory List".
} 
Se uma empresa tivesse a intenção de exportar algum produto considerado proibido, a alçada para os trâmites passaria automaticamente para o Departamento Britânico de Comércio da Guerra (War Trade Department). Empresas exportadoras passaram a ser monitoradas e o Departamento de Comércio ganhou poderes para inibir os processos de exportação em qualquer estágio, tudo com base nas famosas análises dos especialistas, eufemismo para espionagem ou contraespionagem. O Departamento de Comércio Britânico, como estratégia para diminuir as críticas ao cerceamento da liberdade, fazia chegar ao público que as atitudes que passaram a ser tomadas tinham como objetivo maior evitar que empresários britânicos acabassem ajudando o inimigo por ingenuidade, algo natural em um mundo em guerra. As habilidades de homens de negócio eram adequadas aos tempos de paz, mas a guerra exigia medidas de exceção que não faziam parte, e não se esperava que fizessem, da área dos empresários. Para a realização deste trabalho complexo, o Departamento de Comércio decidiu que as explicações sobre a participação da polícia e de investigadores deveria ser sempre creditada como indissociavelmente relacionada ao propósito maior e amplamente aceito pela sociedade que era o de evitar a transferência de recursos aos povos inimigos. ${ }^{392}$

\section{(3) Geral}

Como prerrogativa geral, o Departamento de Comércio passou a atuar com os outros agentes do governo britânico, principalmente a Marinha, no sentido de desviar cargas para o Reino Unido ou para os aliados que tinham os portos inimigos como destino original. Isto seria possível graças à estrutura montada no Departamento dos Correios e Telégrafos que foi orientado a como identificar correspondências suspeitas, habilidade que seria repassada aos países aliados, permitindo uma grande rede de informações sobre o transporte de carga na Europa.

Os departamentos diretamente envolvidos com a operação "Negociando com o Inimigo" foram o Ministério das Relações Exteriores do Reino Unido, encarregado da administração geral, dos embarques de mercadorias de origem belga para países neutros e para o Egito e da Comissão de Assistência Belga; o Home Office, que cuidava das infrações à lista de exceções, das licenças de comércio para empresas britânicas e da análise dos casos de mercadorias suspeitas de ter origem inimiga; Arthur Thring, K.C.B., responsável pelos pagamentos aos países inimigos e à Bélgica, seguros internacionais e

\footnotetext{
${ }^{392}$ Ibidem.
} 
questões bancárias; The Public Trustee, registro e administração de propriedades pertencentes aos inimigos; Board of Trade, patentes e marcas registradas, importações de produtos de países inimigos ou de origem inimiga de países neutros, comunicação com os países inimigos, designação de inspetores e supervisores de empresas britânicas, importação de mercadorias de origem belga no Reino Unido. ${ }^{393}$

O grande problema que pairou sobre a lista de exceções durante toda a guerra foi como definir com exatidão quando uma empresa, um produto ou um empresário era de origem inimiga. $\mathrm{O}$ fato de um empresário ter nascido em um país da Tríplice Aliança não era justo o suficiente para marcá-lo como de origem inimiga e impedi-lo de participar de negócios internos ou do comércio exterior. Para dirimir estas questões que se avolumaram durante a guerra, o Governo Britânico emitiu uma cartilha de uso restrito orientando a burocracia britânica alocada em diversos pontos do mundo a decidir quais os casos deveriam ser incluídos na lista de exceção. Estas orientações, de maneira resumida, diziam que os casos deveriam ser analisados de acordo com a seguinte dimensão:

1) Empresas de nacionalidade inimiga

Deveriam ser consideradas inimigas as empresas que tivessem todos os sócios residentes em países inimigos ou se alguns dos sócios residissem em países inimigos, mas, neste último caso, a empresa deveria ser analisada pelo governo britânico que teria a palavra final. Havia, ainda, a preocupação com empresas que pareciam ser pertencentes a países neutros ou aos aliados, mas que eram financiadas por capital alemão. Interessante notar que o governo britânico não teve o cuidado de se preocupar com outras origens de capital produtivo, muito porque, como se viu nos documentos, havia a certeza de que a quase totalidade dos casos de financiamento que disfarçava a origem do capital era protagonizado pelos alemães. As filiais de empresas sediadas em países inimigos deveriam ser todas consideradas como parte da lista de exceção, não importando o grau de relacionamento que os representantes destas empresas tivessem com o mercado local em países neutros ou aliados. A preocupação aqui tem base na experiência que as empresas britânicas tinham acumulado ao longo de muitas décadas no relacionamento com mercados estrangeiros e nos diversos registros de perda de identidade que filiais podem sofrer após longa exposição no contato com mercados locais. ${ }^{394}$

\footnotetext{
${ }^{393}$ Ibidem.

${ }^{394}$ Ibidem.
} 


\section{2) Associação com o inimigo}

Empresas que tivessem 50\% ou mais das ações controladas por capital de origem inimiga deveriam fazer parte da lista de exceções, assim como empresas que tentassem ocultar a origem inimiga por meio de negócios em países neutros. Estes casos causavam grande apreensão na chancelaria britânica porque os países neutros não formavam um bloco com características similares. Na verdade, havia países neutros que estavam distantes das questões europeias, como alguns asiáticos. Por outro lado, havia neutros que mantinham longo relacionamento com empresas inimigas, caso de empresas da América Latina.

A força das empresas alemãs no comércio internacional abria espaço para operações extremamente intrincadas de ocultação da origem do capital. Negócios importantes poderiam ser celebrados entre estas empresas e países aliados, até mesmo no Reino Unido. Foi muito difícil para o governo britânico tentar fechar todas as possiblidades que impedissem recursos dos aliados ou de países neutros chegaram à Alemanha. Apesar do elevado grau de preocupação com a transferência de recursos para os inimigos, o governo britânico tinha ciência dos riscos em se criar um clima de histeria que pudesse travar os negócios, motivo pelo qual era limitada a entrada de uma empresa na lista de exceções. O objetivo era que este instrumento fosse considerado realmente como exceção e não como uma nova regra para o comércio internacional. Para estabelecer critérios para os casos duvidosos, o governo britânico definiu que não eram casos de inclusão na lista de exceções: ${ }^{395}$

- empresa que fosse considerada como não confiável;

- empresa que não apresentasse garantias suficientes de neutralidade;

- empresa suspeita de remessa de bens a país inimigo;

- empresa representante de empresa sediada em país inimigo;

- empresa com contrato de prestação de serviços a empresa de país inimigo;

- empresa com sócio que tivesse atitude pró-germânica;

\footnotetext{
${ }^{395}$ Ibidem.
} 
Em nenhum destes casos a empresa deveria entrar para a lista de exceções. A dificuldade em cadastrar uma empresa como uma inimiga era proporcional à da retirada de uma empresa da lista de exceções. O processo era extremamente burocrático, exigindo aprovações do alto escalão do governo britânico. ${ }^{396}$

A atuação do serviço secreto era importante para a lista de exceções, mas até mesmo o governo britânico deixava claro que o fato de uma empresa constar das investigações não era motivo para a sua inclusão na lista de exceção. Até mesmo relatórios dos governos francês ou russo informando que uma determinada empresa havia realizado negócios com o inimigo deveriam ser interpretados e analisados com ponderação. Havia a preocupação do governo britânico em não isolar demais o país, principalmente em época de gastos diários com a guerra que somavam aproximadamente $£$ 5milhões em operações bélicas e de estratégia. ${ }^{397}$

A lógica de manutenção dos negócios internacionais em níveis mínimos norteou a administração da lista de exceções. Situações de baixo impacto econômico deveriam ser analisadas na proporção adequada. Havia a clara preocupação de evitar que a guerra afetasse ainda mais os negócios. Empresas não poderiam ser alijadas do comércio exterior por temores que se provavam infundados ou mesmo por zelo excessivo nas relações comerciais com os inimigos. Fazer publicidade da lista de exceções, por exemplo, era sumariamente desaconselhado porque isto poderia contaminar a sociedade com elementos que deveriam e tinham que ficar restritos a analistas e ao governo. ${ }^{398}$

Cuidado especial deveria ser tomado com os casos de exportação de produtos sazonais porque o plantio, a colheita e os embarques eram planejados com muita antecedência e não se podia correr o risco de perder quantidades de produtos e de recursos consideráveis porque uma empresa estava sendo investigada, por exemplo. Se o caso for realmente de lista de exceção, o suprimento da empresa inimiga dever ser cortado imediatamente, afetando na base a capacidade do país inimigo em repor a oferta em outros mercados, notadamente nos Estados Unidos. ${ }^{399}$

\footnotetext{
396 Ibidem.

${ }^{397}$ Wileman's Brazilian Review, 21 março 1916, p. 176.

${ }^{398}$ FO 833/16/10618, janeiro 1916. Carta do War Trade Intelligence Department Department para Gabinete do Ministro de Munições, Worthington-Evans. 18 março 1916.

${ }^{399}$ Ibidem.
} 
Os documentos mostram que a maior preocupação era a de evitar que empresas de países neutros fizessem negócios com empresas listadas na lista de exceção. O problema residia obviamente em como obrigar outros países a seguir as instruções do corpo diplomático britânico. A maneira mais indicada era por meio da diplomacia financeira, como os britânicos se referiam às ameaças impostas às nações neutras quando estas necessitassem de recursos, o que era recorrente, ainda mais em tempos de guerra. O Brasil se enquadrava à perfeição nesta situação e o governo britânico não perdeu oportunidade de fazer valer os seus interesses, mesmo que isto significasse desrespeito à soberania brasileira. Havia ainda a preocupação de orientar empresas que teriam que deixar de fazer negócios com companhias da lista de exceção a como encontrar outros parceiros e quais deveriam ser os canais utilizados para tanto, demonstrando que proibir e abandonar a empresa à própria sorte não era a conduta indicada pelos altos escalões que administravam a lista de exceção, inclusive nos momentos mais críticos da guerra. ${ }^{400}$

A facilidade e a rapidez com as quais o Departamento de Comércio Exterior obtinha informações sobre empresas que deveriam entrar para a lista de exceção fez com que a área militar do governo britânico solicitasse uma parceria mais próxima com a área militar, com ênfase para os casos de bancos que fossem considerados financiadores de operações com o inimigo, dado o potencial de benefícios que estes negócios poderiam provocar na capacidade inimiga de sustentação da guerra. Empresas da lista de exceção que tivessem operações fora da Europa, mesmo em Portugal ou na Espanha, deveriam ser acompanhadas exclusivamente pelo Departamento de Comércio Exterior, deixando para o gabinete militar os casos nos quais a proximidade e o potencial de danos diretos ao Reino Unido fossem evidentes. ${ }^{401}$

Para que uma empresa pudesse ser retirada da lista de exceção seria necessário mensurar o poder do solicitante. Quando a demanda partia de empresas outras ou de pessoas que não as diretamente envolvidas com a empresa em questão, a consideração por parte do Departamento de Comércio Exterior deveria ser sensivelmente menor do que quando a solicitasse tivesse origem em câmaras de comércio, por exemplo. De modo geral, quando uma decisão contra a inclusão de uma empresa na lista de exceção for tomada estritamente com base em termos comerciais, deveriam ser fornecidas opções de licenciamento para atender a demanda. Os melhores aconselhamentos sobre alternativas de

\footnotetext{
${ }^{400}$ Ibidem.

${ }^{401}$ Ibidem.
} 
negócios travados pela lista de exceção poderiam ser obtidos junto aos comerciantes locais e aos gerentes de agências bancárias, que eram, naturalmente, os maiores conhecedores do maior leque possível de opções que evitassem o cerceamento das atividades comerciais e industriais. $^{402}$

Por meio de espionagem em cartas privadas, documentos de empresas e de governos, o governo britânico considerou ao final de 1916 que havia muitas evidências do poder da lista de exceção como medida bélica. O sucesso da operação foi constatado no conjunto dos resultados, com relatos de casos emblemáticos nos quais foi possível atravessar os planos dos inimigos, mas as operações tinham que ser aperfeiçoadas para equilibrar as evidências de sucesso no mundo. Para administrar melhor estes resultados, o governo britânico emitiu extenso relatório no qual são listados os casos de efeitos gerais que foram de alguma forma universais e depois entrar no detalhamento dos principais países afetados pelas investidas alemãs e, consequentemente, pelos métodos da lista de exceção. $^{403}$

O grande mérito da lista de exceção foi ter encontrado número expressivo de artifícios utilizados por empresas alemãs para tentar continuar suas atividades durante a guerra. Algumas empresas chegavam a utilizar até 20 nomes diferentes com sedes em países neutros, demonstrando o poder da lista de exceção porque o custo da mudança de marca tinha implicações certas nos custos e nas vendas destas empresas. Outra vantagem da lista de exceção foi ter forçado, por meio do reconhecimento do seu poder fiscalizador, a desassociação entre empresas de países neutros e empresas de capital inimigo. Muitas empresas passaram a temer os prejuízos que a inclusão na lista de exceção poderia trazer. Prova cabal dos resultados positivos da lista de exceção foi a colaboração dos principais armadores do mundo que passaram a recusar o transporte de mercadorias de empresas que constassem da lista de exceção, fato que, isoladamente, podia indicar como deve ter sido difícil para casas alemãs manter o suprimento a partir de países neutros. Em relação ao financiamento, elemento basilar do comércio exterior, os bancos dos países aliados ao Reino Unido também passaram a recusar liberar linhas de crédito aos processos que envolvessem empresas da lista de exceção, até mesmo para o recebimento de cartas de crédito. $^{404}$

\footnotetext{
${ }^{402}$ FO 833/16/88325, "Effects of lista de exceção on enemy firms", 03 novembro 1916, p. 1-13.

403 Ibidem.

${ }^{404}$ FO 833/16/105280, 22 janeiro 1917, "The Statutory List in the blockade countries".
} 
Por tudo isto, o governo britânico acreditava que a capacidade operacional de um número incalculável de empresas alemãs estava sendo severamente restringido, levando algumas grandes corporações à dissolução. Observando estas consequências nefastas sobre os negócios com capital alemão, o Departamento de Comércio Exterior do Reino Unido passou a computar um número expressivo de empresas que passaram a fazer negócios com empresas britânicas devido à impossibilidade de continuar suas relações com empresas alemãs. Interessante notar como a burocracia britânica deixou transparecer em diversos documentos a realidade dos objetivos da lista de exceção e sem eufemismos registrou que o alvo principal das ações durante a guerra eram mesmo o Império Alemão. Foi possível observar, ainda, a intimidade com a qual o governo britânico tratou as estratégias das empresas alemãs, fruto da longa e próxima convivência que as duas nações tiveram antes da guerra.

Para ilustrar estas avaliações positivas da lista de exceção, o Departamento de Comércio Exterior desenvolveu um quadro geral contendo as particularidades dos efeitos da lista de exceção nos principais países em todas as partes do mundo, quadro do qual foram extraídos para este estudo os casos que maior relação guardavam com a economia brasileira. Os casos listados abaixo tiveram origem em relatórios do serviço secreto britânico com explicações adicionais do corpo diplomático do governo britânico alocado nos países elencados:

\section{Empresa Berringer \& Ohliger}

Fabricante de borracha. Maior empresa do Pará na lista de exceção. O maior efeito da lista de exceção sobre os negócios da empresa foi ter liquidado com as suas atividades bancárias. Já as exportações de borracha foram reduzidas para menos de $10 \%$ do que esta empresa de capital alemão conseguia antes da lista de exceção. O War Trade Intelligence Department (Departamento de Inteligência Britânico do Comércio da Guerra) informou que este era um caso típico de empresa alemã que conseguiu continuar em operação graças à utilização de empresa de fachada, motivo pelo qual os trabalhos de espionagem deveriam continuar.

\section{Empresa Pralow \& Scholz}

Fabricante de borracha estabelecida na Amazônia. Ações da lista de exceção resultaram no fim das parcerias que esta empresa tinha com empreendimentos de fachada. $\mathrm{O}$ 
Departamento de Inteligência Britânico do Comércio da Guerra ficou exultante quando foi publicado no Wileman Review o fim das operações da empresa no Brasil. A parceria com a Companhia Marítima Lloyd Brasileiro dera resultado e as cargas da Pralow \& Scholz não encontravam mais frete de mercado para as suas exportações.

\section{Outras empresas}

O Relatório Wileman foi utilizado pelo Departamento de Inteligência Britânico do Comércio da Guerra para divulgar ao mercado que as empresas exportadoras de café de capital de países neutros ou aliados estavam conseguindo embarcar quantidade 50\% superior às empresas da lista de exceção. O Relatório Wileman também informou que empresas de Joinville - área de grande preocupação para Londres - estavam reduzindo negócios ou encerrando operações por força da lista de exceção, caso da empresa Gordon \& Gerken fabricante de produtos farmacêuticos (Pomada Minancora). Em carta interceptada de 24/03/1916 da empresa Hoepcke \& Co., importante empresa de navegação de Santa Catarina admitia a impossibilidade de continuar ativa nos mesmos moldes de antes da guerra. Seria necessário alterar o nome da empresa e passar a trabalhar com empresas que não estivessem na lista de exceção. ${ }^{405}$

O Império Alemão se utilizou da imagem que países exportadores tinham nas principais praças para transportar armas e explosivos como se fossem commodities, como no caso das embalagens hermeticamente fechadas de carne argentina descobertas pelo Governo Norueguês quando transportadas por agentes alemães. As embalagens traziam códigos e autorizações compatíveis com as exportações argentinas e tinham sido seladas de tal forma que especulou-se quantas outras remessas teriam se utilizado do mesmo mecanismo no passado recente. ${ }^{406}$

A principal missão da lista de exceção não era impedir a simples exportação ou importação de produtos pelo Império Alemão, mas sim destruir as conexões comerciais que as empresas alemãs, com apoio de Berlim, estabeleceram globalmente a partir da Unificação (1871). Para fugir do bloqueio comercial e da lista de exceção, grandes conglomerados alemães passaram a produzir nos Estados Unidos, como ocorreu com a Bayer \& Company, que passou a exportar Aspirina fabricada em associação com empresa

\footnotetext{
405 Ibidem.

${ }^{406}$ O Estado de S. Paulo, 15 setembro 1917, p. 1.
} 
norte-americana. O governo britânico estava decidido a colocar esta empresa na lista de exceção, apesar das ameaças que Londres já havia recebido de represálias dos americanos que não admitiam investigações de outros serviços secretos sobre atividades em seu território. Impedir o financiamento de negócios alemães nos países neutros por bancos norte-americanos era tarefa das mais complexas, como atestam os relatos das operações do National City Bank of New York na Argentina. As ramificações e conexões entre os banqueiros eram fator de difícil decifração pelos especialistas no governo britânico. ${ }^{407}$

As dificuldades para o Brasil importar juta - matéria prima para a fabricação de sacaria e aniagem em geral - durante a guerra teve relação com a lista de exceções. Em um dos casos registrados pelo governo britânico, a Companhia Mechanica e Importadora adquiriu da Índia 15.000 fardos de juta que foram despachados para Santos em consignação ao vice-cônsul britânico, prática comum durante vigência da lista de exceções. Isto era feito para garantir que o destino final do produto não seria alguma empresa ligada ao Império Alemão. No caso específico, cada um dos clientes finais da Companhia Mechanica e Importadora teria que atender as exigências da circular do governo britânico que obrigava os consumidores finais a provar a utilização do material que seria adquirido por intermédio da importadora. A circular era dirigida aos súditos reais, mas trazia uma advertência que muita preocupação causava no mercado por seu tom de ameaça clara com implicações drásticas para qualquer empresa que participasse do comércio exterior no Brasil, direta ou indiretamente: "toda e qualquer pessoa que auxiliar uma das firmas constantes da Lista Negra, esquivando-se, portanto, dos rigores da proclamação real, expõe-se, ella própria, a se ver inscripta na mesma lista". ${ }^{408}$

A lista de exceções causava problemas de toda ordem nos negócios do Brasil. A Associação do Commercio considerou humilhante a nova obrigação do governo brasileiro de considerar nulos os contratos de compra e venda registrados nas caixas de liquidação quando figurassem em qualquer posição empresas da lista de exceções. A proibição em exportar café para a Holanda e para os países escandinavos deixou os cafeicultores sem um importante mercado na exportação. Os empresários brasileiros acreditavam que quanto mais exigente fosse a lista de exceções, maiores seriam as chances de empresas furarem o

\footnotetext{
${ }^{407}$ FO 833/16/105280, 22 janeiro 1917, “The Statutory List in the blockade countries".

${ }^{408}$ O Estado de S. Paulo, 05 novembro 1916, p. 4.
} 
bloqueio. O lucro de uma operação proibida pelos países da Entente poderia compensar os riscos envolvidos. ${ }^{409}$

Uma das maiores organizações comerciais estruturadas em Manaus para a exploração e o comércio da borracha era a empresa de capital alemão Pralow\& Company. Incluída na lista de exceção, passou a operar em nome de quatros empresas com sede em Portugal e uma no Brasil. Descoberto o esquema, o cônsul britânico conseguiu aprovação para incluí-las na lista. Prova do poder da lista de exceção pode ser verificada na solicitação das quatro empresas portuguesas em obter reavaliação dos seus negócios após eliminar a relação que mantinha com a Pralow \& Company e, desta feita, excluída da nova lista que o governo britânico divulgara ao final de março de 1916. Na opinião do 'O Paiz', a associação de empresas brasileiras em negócios com companhias de capital alemão era mera questão comercial, em nada interferindo em questões da guerra, caso que não se verificava em relação às empresas portuguesas que deveriam mesmo ser 'caçadas' pelos serviços de investigação britânicos porque Portugal não era um país neutro como o Brasil. Não caberia, no entendimento do jornal, indignação quanto a um possível desrespeito à soberania brasileira com o impedimento das operações portuguesas no território nacional porque isto estava plenamente de acordo com as novas normas que passaram a reger as transações internacionais. ${ }^{410}$

O caso ganhou dimensões que forçaram o envolvimento da embaixada portuguesa no Brasil que, em nota divulgada pelo jornal Correio da Manhã, repudiou as tentativas de colocar a República Portuguesa contra o Império Britânico. As duas nações eram aliadas contra a Tríplice Aliança. Os britânicos nada mais tinham feito do que se valerem da ampla facilidade adquirida em negócios no mundo. O Correio da Manhã decidiu avançar na questão e respondeu em editorial que a guerra estava sendo usada como desculpa para que fossem infringidas questões de direito internacional, de direito público e privado. Os britânicos estavam atacando não apenas os inimigos declarados, mas também países aliados e neutros, como se via neste caso da Pralow \& Company. ${ }^{411}$

O caso da empresa brasileira Casa Hoepcke com sede em Florianópolis foi muito comentado no mercado. A inclusão da empresa na lista de exceções inviabilizou a continuidade da produção de tecidos, gelo, metalurgia e navegação por absoluta falta de

\footnotetext{
409 Ibidem.

410 'O Paiz' em O Estado de S. Paulo, 09 abril 1916, p. 3

${ }^{411}$ O Estado de S. Paulo, 08 abril 1916, p. 1.
} 
matéria-prima que passou a ser bloqueada no embarque em portos internacionais. A empresa era considerada com ligações muito estreitas com o capital alemão. Lamentou-se na praça que 200 famílias passariam a ficar sem proventos. ${ }^{412}$

A preocupação em ficar longe da lista de exceção não era exclusividade de países neutros como o Brasil. Empresas americanas que dependiam do comércio exterior foram obrigadas a se precaver e controlar a venda de seus produtos em países neutros. Isto foi noticiado pelo Correio do Povo de Porto Alegre. O jornal teve acesso a grande número de cartas de multinacionais norte-americanas. Estas empresas instavam os seus clientes brasileiros a não comercializar os produtos importados de qualquer tipo de empreendimento que tivesse participação de capital alemão. ${ }^{413}$ Da Suécia vinham reclamações de armadores que foram colocados na lista de exceção e que agora não conseguiam mais nem ser rebocados ao tentar entrar em portos de nações neutras. Tudo porque mantiveram rota marítima entre a Suécia e a Alemanha. ${ }^{414}$

Muito se comemorava quando uma nova lista era publicada e empresas deixavam de figurar como excluídas do comércio com o Reino Unido, o que na prática significava exclusão do comércio exterior como um todo. Uma das praças onde a expectativa era sempre muito elevada era Manaus, que dependia essencialmente da borracha. Ter uma empresa de porte, caso da maioria das comerciais exportadoras, impedida de operar na exportação tinha elevado impacto na atividade da região. ${ }^{415}$

Ricardo Severo, sócio de Ramos de Azevedo em obras de engenharia e arquitetura, foi presidente da Comissão Executiva do Congresso dos Aliados e responsável pelo apoio aos países da Entente em São Paulo. A função precípua do Congresso Comercial dos Aliados era tratar as questões relacionadas ao comércio dos países aliados com o Brasil, da concorrência com empresas de capital alemão e, mais importante, resolver problemas originados com os decretos e regras para o comércio internacional durante a guerra, especialmente a lista de exceções. A origem da Comissão guarda relação com a iniciativa da Câmara Portuguesa de São Paulo que teve adesão das câmaras do Reino Unido, Itália,

\footnotetext{
${ }^{412}$ O Estado de S. Paulo, 23 abril 1916, p. 1.

${ }^{413}$ O Estado de S. Paulo, 08 maio 1916, p. 1.

${ }^{414}$ O Estado de S. Paulo, 08 outubro 1916, p. 1.

${ }^{415}$ O Estado de S. Paulo, 21 setembro 1916, p. 1.
} 
Bélgica e França. Uma das primeiras medidas adotadas foi a validação da lista de exceções, "enquanto disposições de outros países aliados não se verificassem". ${ }^{416}$

As críticas à Comissão Executiva do Congresso dos Aliados eram de toda ordem. Começavam pelo caráter extremamente ideológico espelhado em suas deliberações e publicações que tratava o comércio local brasileiro como se fosse europeu, como se os riscos envolvidos de envolvimento com países inimigos fossem similares. A Comissão respondia que tinha como objetivo defender a lista de exceções e colocar o comércio exterior brasileiro em sintonia com os países aliados. Era uma tarefa praticamente impossível. O comerciante brasileiro não se sentia parte dos esforços de guerra. O cenário que alimentava as decisões da lista de exceções era distante da realidade dos negócios no Brasil. As perguntas que a Comissão teve que ouvir em algumas ocasiões incluíam "por que não se podia comercializar com a Alemanha?”, “quais as ameaças efetivas do Império Alemão para o Brasil?",417

Quando se discutia a validade da lista de exceção sempre aparecia a questão da soberania brasileira, que os atos britânicos eram humilhantes para uma nação independente como o Brasil. Algumas vozes ponderavam a questão e diziam que a legislação britânica atingia os súditos daquele país que não poderiam comprar ou vender para empresas consideradas inimigas, mas o comerciante brasileiro era livre e podia empreender negócios com qualquer empresa de qualquer nacionalidade. O problema, e aí vem a ponderação, era que esta empresa hipotética, genuinamente brasileira, também seria colocada na lista de exceção, situação que causaria fatalmente o isolamento e a asfixia por completo, incapacidade de utilizar transporte internacional, financiamento bancário, armazenagem, ou seja, a lista de exceção era realidade dura para o Brasil. ${ }^{418}$

A política econômica externa dividia o empresariado brasileiro. Comerciantes paulistas em reunião organizada pela Comissão Commercial dos Alliados - instituição que tinha o fito de patrocinar os negócios entre empresários brasileiros e empresas da Entente decidiram se submeter integralmente à lista de exceção, ao contrário do que se passou no Rio de Janeiro, onde havia forte discordância entre os representantes europeus e comerciantes locais. ${ }^{419}$

\footnotetext{
${ }^{416}$ O Estado de S. Paulo, 30 dezembro 1916, p. 3.

${ }^{417}$ Ibidem.

${ }^{418}$ O Estado de S. Paulo, 13 janeiro 1917, p. 7.

${ }^{419}$ O Estado de S. Paulo, 23 dezembro 1916, p. 2.
} 
As regras da lista de exceções tinham impacto no Brasil inteiro, alterando a forma de comercialização até mesmo de produtos que não eram considerados alvo de contrabando. Este foi o caso da exportação de castanhas que representava a segunda fonte de renda do estado do Amazonas. O produto tinha demanda e preços que mobilizaram ações pela melhoria nas condições de transporte para os centros consumidores na Europa e nos Estados Unidos. A logística a partir de Manaus era deficitária e agravara-se com a guerra. O transporte da borracha não estava sendo tão prejudicado quanto o da castanha. A borracha tinha aceitação maior nas companhias marítimas por ocupar menos espaço e ser de mais fácil acomodação, não necessitando de ventilação especial, que fermentava quando estocada de maneira indevida. O fato de muitas casas importadoras de castanha da Europa terem sido adicionadas à lista de exceções limitava ainda mais as possibilidades de embarque nos navios do Llloyd Brasileiro. ${ }^{420}$

Lauro Müller era considerado responsável pelo elevado grau de intromissão que o Reino Unido alcançou em negócios internos do Brasil com a lista de exceção. Os críticos o acusavam de servidão aos interesses dos países aliados, forma que o ex-ministro das Relações Exteriores encontrara para compensar a desconfiança que pairava sobre os seus atos, fruto de sua origem germânica. As modificações que bastaram para amainar os espíritos nacionalistas foram obtidas por Nilo Peçanha, Ministro das Relações Exteriores. Não foi nada revolucionário, apenas um aceno de boa vontade do governo britânico que concordou em consultar o governo brasileiro antes da inclusão de pessoas ou de empresas brasileiras na lista de exceção. O que motivou a abertura desta exceção estava, na verdade, relacionado à politica dos britânicos de cooptação do Brasil para participar da guerra de maneira efetiva, o que viria a ocorrer pouco tempo depois, ao final de outubro de $1917 .{ }^{421}$

Muitas críticas sobre a neutralidade do Brasil. Uma das maneiras de interpretar a declaração de guerra afirmava que o Brasil entrou para um período nas relações internacionais no qual não havia mais nenhuma atitude a defender, que a lista de exceções venceu e o país foi subjugado e atraído para uma aventura sem contornos e que teria como compensação a liberação do café no Reino Unido. A decisão britânica não teria

\footnotetext{
${ }^{420}$ Declarações de Anibal Porto, delegado da Associação Comercial do Amazonas, reproduzidas pelo Jornal do Commercio. O Estado de S. Paulo, p.4

${ }^{421}$ O Estado de S. Paulo, 15 setembro 1917, p.3.
} 
implicações práticas de curto prazo porque os estoques britânicos estavam completos e poderiam ficar meses sem novas entradas. ${ }^{422}$

Os informes diplomáticos que Londres fazia chegar às embaixadas e representações britânicas espalhadas pelo mundo davam conta que a lista de exceções era uma medida basicamente administrativa e que tinha como objetivo maior controlar as atividades mercantis de pessoas e empresas do Reino Unido, evitando que nações inimigas se apoderassem de recursos por meio de organizações comerciais e industriais de capital britânico. O problema era que a supranacionalidade da lista de exceções logo ficou patente. Muitos países neutros foram obrigados a se submeter a mudanças no comércio exterior que, na prática, significaram também ingerência britânica em questões internas dos países mais afetados. ${ }^{423}$

A maioria dos países neutros se caracterizava como de economia tradicional, com larga dependência de exportações de primários. Não seguir a lista de exceções criava ou ampliava focos de crise econômica e financeira interna. Isto alimentava crises sociais e políticas, obrigando o governo a gastar recursos em ouro. Estes recursos chegavam aos países neutros por meio de empréstimos ou via exportações. Se uma grande empresa exportadora sediada em país neutro não seguisse as regras da lista de exceções, todo o país poderia sofrer com as consequências econômicas. ${ }^{424}$

Associações de classe e jornais pró-britânicos tentaram defender as medidas da lista de exceções. A ideia era explicar o caráter preventivo que as alicerçava, estabelecendo comparações com o direito de qualquer nação soberana em legislar sobre tributação aduaneira. Se em tempos de paz era genuíno o estabelecimento de medidas protecionistas em relação com comércio internacional, nada mais natural deveria ser a compreensão de critérios que ambicionavam meramente salvaguardar vidas frente a um "inimigo tão poderoso" quanto o Império Alemão. ${ }^{425}$

Se as restrições ao comércio exterior estavam afetando de maneira tão intensa o Brasil, os aliados do Reino Unido diziam que claramente este não era e nem poderia ser o objetivo final, que o Brasil poderia continuar comprando carvão de Cardiff ou vendendo café para Birmingham por meio de armadores britânicos, mas era razoável que a sociedade

\footnotetext{
422 'As miragens do Itamaraty'. O Estado de S. Paulo, 7 outubro 1917, p. 11.

${ }^{423}$ Wileman Review, 25 julho 1916, p. 451.

${ }^{424}$ Ibidem.

425 "The Statutory List in the blockade countries", 22 janeiro 1917, FO 833/16/105280.
} 
brasileira percebesse que o governo britânico não poderia tolerar a utilização destas mercadorias por empresas que atuavam como extensão de Berlim e eram subservientes no mais alto grau à Alemanha. Os inconvenientes efeitos colaterais da lista de exceção demonstravam, de acordo com o discurso do governo britânico, a extensão do poder comercial e econômico da Alemanha que se ramificou de tal forma desde o final do século XIX que acabou por envolver muitos interesses econômicos do Brasil. Após o Convênio de Taubaté foi montado um truste para escoar grande parte da produção de café que chegava até Santos em vapores alemães que levavam as sacas até Hamburg e de lá para toda a Europa. Era uma complexa rede cartelizada controlada pela empresa Theodor Wille \& Company. $^{426}$

Segundo a visão britânica, se as medidas tomadas para derrotar a Alemanha estavam causando dissabores no Brasil, o mundo do pós-guerra prometia condições mais vantajosas para o comércio exterior do país que estaria definitivamente livre do modo alemão de fazer negócios, caracterizado por centralização e cartelização das atividades, resultando em lucros menores que em um contexto de operações livres e diversificadas. Se havia dúvidas sobre a capacidade de valorização da liberdade comercial que era característica do modo britânico de fazer negócios, bastava uma simples comparação com o bloqueio sem diálogo que os submarinos do Império Alemão executavam em largas faixas das águas internacionais, como acontecera com o vapor brasileiro 'Rio Branco'. Se a esta análise for adicionada a pendência de repatriação de recursos do estado de São Paulo em poder do Governo Alemão, ficavam mais nítidas ainda as distinções entre as duas formas de administração de temas relacionados à economia internacional, o britânico, com ponderação dos elementos, e o alemão, com regras que não distinguiam conjunturas diferentes e tratavam tudo na base do belicismo. A estes defensores anglófilos não era concebível que tanta grita e energia fossem direcionadas contra a lista de exceção e quase nada às atrocidades praticadas pelos alemães. Ao permitir que países neutros comercializassem o que pretendessem com os inimigos, o Reino Unido agia como o proprietário de um estabelecimento cercado por bandidos que são convidados para jantar e ainda saem com munição renovada. ${ }^{427}$

$\mathrm{Na}$ interpretação da Entente, a utilidade da lista de exceção era proporcional ao envolvimento do país-alvo na guerra. Em países beligerantes aliados, a lista de exceção

\footnotetext{
${ }^{426}$ Ibidem.

${ }^{427}$ Ibidem.
} 
tinha campo de ação menor porque já havia sistemas próprios de controle das relações com os inimigos, já nos países inimigos, o bloqueio comercial resolvia grande parte do problema. Era em nações neutras que a lista de exceções fazia realmente a diferença e onde se justificava a estrutura de controle com base em Londres porque o país passava a ter as suas relações internacionais alteradas. No Brasil, a lista de exceção colocou fim em rotas de comércio, fechou empresas e implantou novas regras de mercado, motivo pelo qual a relação do país com este instrumento de guerra ter sido intensa e direcionadora da política econômica e do desenvolvimento do país. A imagem do Reino Unido nos países neutros piorava com o sucesso da lista de exceção, mas o Departamento de Comércio Exterior acreditava que o prestígio dos britânicos como referência mundial na organização social e na produção cultural compensavam o desgaste que se esperava passageiro, a não ser nos locais nos quais a presença da colonização germânica era mais concentrada, como na Argentina e no Sul do Brasil. ${ }^{428}$

Na América Latina, de acordo com estimativa da imprensa britânica, faziam parte da lista de exceção 39 empresas estabelecidas na Argentina, 66 no Brasil, 28 no Equador e 17 no Peru. Algumas destas empresas da lista de exceção para o Brasil podem ser observadas na Figura 10.1 que contém o nome do estabelecimento identificado em Londres e a sede da empresa. Interessante observar a diversidade de locais no Brasil que foram base de empresas consideradas como inimigas ou relacionadas à Aliança. Ainda com base na informação divulgada por Londres, 72 estabelecimentos foram fechados ou cerceados porque mantiveram relacionamento comercial ou financeiro com o Império Alemão. ${ }^{429}$

O caso de Eduardo Fernandes Correa foi sintomático. O comerciante do Rio de Janeiro decidiu processar a empresa American Coal Sporting Company por esta não ter honrado o contrato de venda de sete mil toneladas de carvão. O importador não conseguira atender as exigências da lista de exceção, pré-condição do fornecedor norte-americano para que o negócio fosse cumprido. Como defesa, o comerciante alegou que o contrato fora firmado entre duas empresas de países não envolvidos na guerra e que não cabia a interferência de autoridades britânicas em operações com este perfil. ${ }^{430}$

As restrições impostas pela lista de exceção fizeram os debates no Congresso dos Estados Unidos alcançar um grau que obrigou a participação direta do presidente

\footnotetext{
428 Ibidem.

429 O Estado de S. Paulo, 26 março 1916, p. 1.

${ }^{430}$ O Estado de S. Paulo, 22 outubro 1916, p. 1.
} 
Woodrow Wilson. O presidente teve que amenizar as críticas ao crime que as empresas americanas acreditavam que estava sendo praticado contra o livre comércio. A falta de borracha para a indústria automobilística foi um dos casos discutidos. ${ }^{431} \mathrm{~A}$ força da economia norte-americana refletia-se nas decisões em Londres. Até julho de 1916 a lista de exceções ainda não havia normatizado o comércio com inimigo envolvendo os Estados Unidos, onde continuava em vigor a black list, direcionada especialmente para o setor financeiro. $^{432}$

No Brasil, a lista de exceções incluiu diversas empresas em muitas regiões do país. O Anexo I contém os dados das empresas que figuravam na lista em junho de 1916. Estas informações eram divulgadas pelos jornais brasileiros de maior circulação, o que fazia a lista de exceções assunto debatido pela sociedade. ${ }^{433}$

\footnotetext{
${ }^{431}$ O Estado de S. Paulo, 10 novembro 1916, p. 3.

${ }^{432}$ Wileman Review, 25 julho 1916, p. 451.

${ }^{433}$ O Estado de S. Paulo, 29 junho 1916, p. 10.
} 
Figura 10.1 - Statutory List Brasil, junho 1916.

\begin{tabular}{|c|c|c|c|}
\hline Empresa & Sede & Empresa & Sede \\
\hline A. Alves da Motta & Rio de Janeiro & Freidheim Aguiar \& Company & $\mathrm{n} / \mathrm{c}$ \\
\hline Abílio Fonseca & Pará e Rio de Janeiro & Friedrichs \& Timmans & Bahia \\
\hline Ahrns Eduardo & Bahia & Fritz Engel & Rio Grande do Sul \\
\hline Albuquerque, Antonio de & Pará & Gaz Motoren Fabrik Deutz & Rio de Janeiro \\
\hline Arp \& Company & $\begin{array}{l}\text { Rio de Janeiro, São Paulo } \\
\text { e Hamburgo, Alemanha }\end{array}$ & $\begin{array}{l}\text { Guimarães \& Company } \\
\text { (fachada para Arp \& Company) }\end{array}$ & Rio de Janeiro \\
\hline Barza \& Company & Pernambuco & Graeff Gustaf & Pará \\
\hline Bayer Frederico \& Company & Elberfeld, Alemanha & Green \& Company & Pará \\
\hline Behrmann \& Company & Bahia & Griesbach Max & Pará \\
\hline Bellingrodt \& Meyer & Rio de Janeiro & Hartmann $\mathrm{H}$. & Pernambuco \\
\hline Berringer \& Company & Pará & Hasenclever \& Company & Rio de Janeiro e São Paulo \\
\hline Bezold Otto & $\begin{array}{l}\text { Ceará } \\
\text { Pernambuco e Maceio, }\end{array}$ & Hoepcke Carl & Santa Catarina \\
\hline Borstelmann \& Company & Alagoas & Hoffmann Rudolf W. H. & Pará \\
\hline Bluhm Bernard & Maranhão & Holzborn Ernesto & Bahia \\
\hline Brando Viúva Carlos \& Company & Florianópolis, SC & Huland Oscar & Ceará \\
\hline Breithaupt Victor \& Company & Santos, SP & Janowitzer Wahle & Riode Janeiro, São Paulo, \\
\hline Brockman A. & Pernambuco & & Áustria e Alemanha \\
\hline Bromberg \& Company & $\mathrm{n} / \mathrm{c}$ & João Silbveira de Souza & \\
\hline Bromberg Hacker \& Company & $\mathrm{n} / \mathrm{c}$ & (fachada para Jordan Gerken) & $\mathrm{n} / \mathrm{c}$ \\
\hline Carioca Manuel Vicente & Manaus, AM & Jordan Gerke \& Company & Santa Cataraina \\
\hline Casa Alemã & São Paulo e Santos, SP & Kuehlen Otto & $\begin{array}{l}\text { Pará } \\
\text { Amazonas, Pará, Maranhão }\end{array}$ \\
\hline Casa Fuchs & São Paulo, SP & Krause Irmãos & $\mathrm{e}$ \\
\hline Companhia Commercial & Vitória, ES & & Pernambuco \\
\hline
\end{tabular}




\begin{tabular}{|c|c|c|c|}
\hline Empresa & Sede & Empresa & Sede \\
\hline Costa Ferreira & São Paulo e Santos, SP & Kroncke \& Company & Paraíba \\
\hline Dannemann \& Company & Bahia & Landy Carlos Von & Pernambuco \\
\hline Dauch \& Company & Santos, SP & Lauro Linhares & Santa Catarina \\
\hline Deffner \& Company & Manaus, AM & Lemcke Carlos & Rio Grande do Sul \\
\hline Deutsche Gasmotoren Fabrick & Pernambuco & Lind von der \& Company & Bahia \\
\hline Diaz Garcia \& Company & Rio de Janeiro & Lobo M. (fachada) & Amazonas \\
\hline Diebold \& Company & Santos, SP & Lohse \& Company & Pará \\
\hline Domschke \& Company & Bahia & M. da Costa Almeida \& Company & Rio de Janeiro \\
\hline Eiffer Bernard & Pernambuco & Magnus \& Company James & Rio de Janeiro \\
\hline Empresa Hoepcke & Florianópolis, SC & Meyer Irmãos \& Company & Rio Grande do Sul \\
\hline Empresa Navehação & & Monteiro J. A. & Rio de Janeiro \\
\hline Mosqueiro Soure & Pará & $\begin{array}{l}\text { Monteiro Santos \& Company } \\
\text { (fachada para A. Trommel \& }\end{array}$ & \\
\hline Engelhardt Carlos & Rio Grande do Sul & Company) & São Paulo \\
\hline Ferreira J. G. & Rio de Janeiro & Moreira Julio Cesar & Rio de Janeiro \\
\hline Ferreira da Costa & Santos, SP & Noronha Carlos de & Rio de Janeiro \\
\hline Fischer Christino & Porto Alegre, RS & Ohliger \& Company & Pará e Amazonas \\
\hline $\begin{array}{l}\text { Fonseca Arthur } \\
\text { (fachada para Carl Hoepcke }\end{array}$ & & Ornstein \& Company & Rio de Janeiro \\
\hline Company) & São Francisco do Sul, SC & Oftens K. J. & Bahia \\
\hline Fonseca \& Company & Pará & Overbeck \& Company W. & Bahia \\
\hline Fraeb \& Company & Rio Grande do Sul & Petersen Adolf \& Company & Pernambuco \\
\hline Empresa & Sede & & \\
\hline Pook \& Company & Bahia e Rio Grande do Sul & & \\
\hline Pradez Pierre & Rio de Janeiro & & \\
\hline Pralow \& Company & Amazonas & & \\
\hline
\end{tabular}




\begin{tabular}{llll}
\hline Empresa & Sede & Empresa & Sede \\
\hline Ricardo Naschold \& Company & São Paulo & Urban \& Company Eugen & Rio de Janeiro, São Paulo e \\
Rombauer \& Company & Rio de Janeiro & & Alemanha \\
Rosa Neves \& Company & Santa Catarina & Vasconcellos José de & Pernambuco \\
Rothschild \& Company & São Paulo & Vianna Elysio & Pernambuco \\
Runes \& Bark & São Paulo & Wagner Schadlich \& Company & São Paulo \\
Seligmann \& Company & Pará & (fachada para Casa Alema) & Pará \\
Semper \& Company & Amazonas & Weigant \& Company & São Paulo \\
Simonek \& Moreira & Pernambuco & Weissflog Irmãos & Bahia \\
Sinner Alf & Rio de Janeiro & Westphalen Bach \& Company & Rio de Janeiro, São Paulo e \\
S/A Amazonense Andresens & Amazonas & Wille \& Company Theodor & Alemanha \\
Solheiro Luiz & Pará & & Pernambuco \\
Surdieck \& Company & Bahia & Brockmann & Pernambuco \\
Schlee Philip & Amazonas & Wolf Eni & Rio Grande do Sul \\
Schoen Roberto & Rio de Janeiro & Ribeiro Amando & Santa Catarina \\
Schoz Waldemar & Amazonas & Lauro Linhares & Pará e Rio de Janeiro \\
Schumann \& Company & Pará & D. Pracedta A. Alves & Mato Grosso \\
Steinberg Meyer \& Company & Rio de Janeiro & Stofen Schnack Müller\& Company & Amazonas \\
Steiner Martins \& Company & Pará & Strassberger \& Company & Bahia \\
Steinmann Emilio & Amazonas & Studor J. & Rio Grande do Sul \\
Stender \& Company & Bahia & Teltscher \& Company & São Paulo \\
& & Trommel A. \& Company &
\end{tabular}

Fonte: O Estado de S. Paulo, 29 junho 1916, p. 10 - reprodução de publicação oficial do Governo Britânico. 
Os impactos da guerra no comércio internacional do Brasil foram suficientes para alterar a política econômica do governo de Wenceslau Braz. Às restrições na logística e à falta de financiamento em ouro se somaram os controles da lista de exceção e as alterações nos fornecedores internacionais. O Brasil foi obrigado a diversificar a pauta de exportações, a mudar a forma de comercialização dos produtos, a negociar produtos como café e borracha diretamente com governos da Entente. A falta de divisas limitou as importações e dificultou a geração da renda aduaneira, além de ter obstado o desenvolvimento industrial pela falta de matériasprimas e equipamentos industriais, temas desenvolvidos na próxima seção.

\section{Seção 10.2 - Comércio exterior}

A guerra modificou o fluxo e as regras do comércio internacional. Governos de países que dependiam em diferentes graus da economia internacional tinham em Londres o foco para as reclamações porque o Reino Unido era considerado responsável pela lista de exceções, sistema que causava diminuição na margem de lucro e perda de mercados. Em resposta às intensas e frequentes críticas que especialmente o governo dos Estados Unidos fazia sobre as restrições impostas ao comércio internacional, a diplomacia britânica decidiu enumerar os motivos que justificavam as medidas adotadas e enfatizar que os problemas nos negócios internacionais eram provocados pela guerra e não por opção do governo britânico. Esta situação, dizia Londres, afetava não apenas as nações beligerantes, mas a todos os países. No caso específico das reclamações de Washington, a diplomacia britânica realizou levantamentos estatísticos que identificaram efeitos positivos da guerra nas exportações norte-americanas que cresceram em valor, exceção às vendas de algodão. Se havia problemas nas vendas norte-americanas no exterior, a causa deveria ser outra que não a lista de exceção. ${ }^{434}$

Para o comércio exterior brasileiro, a guerra significou valores importados e exportados inferiores aos verificados antes do conflito. Tomando-se o ano de 1913 como referência ${ }^{435}$, verifica-se que tanto as importações quanto as exportações

\footnotetext{
${ }^{434}$ ADM 137/2736, fevereiro 1915, "Draft answer to the United States Protest", p. 1-14.

${ }^{435}$ Apesar de 1913 ter sido o último de relações comerciais internacionais normais antes da guerra, há que se considerar que a atividade econômica estava envolvida em crise que dera os primeiros sinais ainda em 1912, como discutido na seção 1.1 .
} 
sofreram reduções durante a guerra, interrompendo o crescimento que fora observado entre 1911 e 1913, conforme demonstrado na Tabela 10.1.

Uma distinção importante a fazer é que as importações apresentaram queda superior às exportações, indicando que o comércio importador teve atividades comprometidas durante a guerra e que as rendas aduaneiras arrecadaram menos porque tiveram bases de cálculo reduzidas até 1919. A guerra teve impacto expressivo sobre a atividade importadora logo no primeiro ano do conflito, que caiu pela metade. A depressão sobre o setor continuou muito forte em 1915, a partir de quando começou uma recuperação moderada.

Apesar de as exportações também terem sido menores durante a guerra em comparação a 1913, o impacto dos eventos internacionais sobre o setor foi menor que o constatado para as importações. A Tabela 10.1 mostra que a redução no primeiro ano da guerra foi de aproximadamente 30\%, mas logo a partir de 1915 começou a recuperação e em 1917 os valores exportados foram praticamente iguais ao ano de referência. Vale destacar que as exportações, ao contrário das importações, estavam em queda pelo menos desde 1911, muito por conta das crises balcânicas e dos problemas com as vendas internacionais de café e borracha.

Tabela 10.1 - Comércio Exterior do Brasil 1911-1919 (libra esterlina, mil).

\begin{tabular}{|c|c|c|c|c|}
\hline Ano & Importação & $\begin{array}{l}\text { Variação } \\
\text { s/1913 }\end{array}$ & Exportação & $\begin{array}{l}\text { Variação } \\
\text { s/1913 }\end{array}$ \\
\hline 1911 & 52.822 & $-21,36 \%$ & 66.839 & $2,12 \%$ \\
\hline 1912 & 63.425 & $-5,57 \%$ & 74.649 & $14,05 \%$ \\
\hline 1913 & 67.166 & - & 65.451 & - \\
\hline 1914 & 35.473 & $-47,19 \%$ & 46.803 & $-28,49 \%$ \\
\hline 1915 & 30.088 & $-55,20 \%$ & 53.951 & $-17,57 \%$ \\
\hline 1916 & 40.369 & $-39,90 \%$ & 56.462 & $-13,73 \%$ \\
\hline 1917 & 44.510 & $-33,73 \%$ & 63.031 & $-3,70 \%$ \\
\hline 1918 & 52.817 & $-21,36 \%$ & 61.168 & $-6,54 \%$ \\
\hline 1919 & 78.177 & $16,39 \%$ & 130.085 & $98,75 \%$ \\
\hline
\end{tabular}

Análise do ministério da Fazenda do Brasil acusava que os efeitos negativos da guerra eram previsíveis, principalmente quando ficaram explícitos as suas 
imposições e antagonismos. O golpe no comércio exterior foi duro, e as causas podem ser encontradas na radical alteração dos transportes internacionais, com rotas suprimidas, fechamento de portos e perda de mercados. O valor dos produtos exportados pelo Brasil decresceu de maneira acentuada na guerra. Faltaram matériasprimas e produtos de consumo final. O governo brasileiro interpretou os efeitos da guerra sobre o comércio exterior como conflitantes porque ao mesmo tempo em que novos produtos passaram a ser demandados pelos países mais diretamente envolvidos no conflito, as dificuldades para a concretização dos negócios foram elevadas e acabaram por criar um novo modo de operação das vendas ao exterior. $\mathrm{Na}$ parte final da guerra, alguns dos entraves foram suprimidos e o valor médio dos produtos exportados aumentou, mas persistiu de maneira marcante a falta de meios de transporte interno e externo pelos motivos de cerceamento naturais da guerra que se somaram à falta de opções de barcos para operações internas no Brasil. O deslocamento de paquetes para a o patrulhamento do litoral do país somente fez agravar o quadro que já estava comprometido com a falta de carvão, combustível fundamental para a logística e que somente com o fim da guerra teve o fornecimento regularizado. ${ }^{436}$

A escassez de combustível tinha parte da explicação no fato da guerra ter aumentado o consumo de carvão, mas parte do problema no Brasil estava relacionada à interrupção do fluxo de comércio. Isto impedia o livre acesso ao carvão e aos produtos que antes eram regularmente importados. A falta de divisas comprometia sobremaneira o comércio importador. A situação levou o governo brasileiro a solicitar a abertura de crédito especial na Commission Internationale de Ravitaillement - Estrutura criada pela Entente para o suprimento dos países aliados no mercado internacional. O objetivo do Brasil era obter recursos para aquisições de produtos do Reino Unido em solicitação que envolveu os Rothschild e que previa a liquidação dos desembolsos por meio de exportações futuras. ${ }^{437}$ Solicitar recursos à Entente para repassá-los aos países aliados parecia algo factível de aprovação.

A carência de carvão afetou a indústria brasileira, mas é provável que o maior problema para o setor tenha sido a falta de investimentos na aquisição de

\footnotetext{
${ }^{436}$ Relatório Ministério da Fazenda, 1917-I, p. 40.

437 T 1/12208/4887, 04 fevereiro 1918, carta da Commission Internationale de Ravitaillement Londres endereçada ao FO datada de 17 novembro 1917.
} 
equipamento industrial. A demanda por produtos fabricados no Brasil aumentou durante a guerra, como atestam os documentos pesquisados e como defendem os autores que se debruçaram sobre a industrialização brasileira antes de 1930. O problema é como explicar que a indústria nacional tenha se desenvolvido de maneira perene quando se sabe da falta de ouro até para o suprimento de artigos importados essenciais. Verificando-se o conjunto das importações de bens de capital para a indústria exposto na Tabela 10.2 fica patente a impossibilidade de avanço do setor durante a guerra que permitisse continuar o processo de maneira sustentável após 1918.

Tabela 10.2 - Valor da importação de equipamento industrial (libras esterlinas a preços de 1913).

\begin{tabular}{l|r|r} 
& & Var. $\%$ \\
1910 & 1.733 .234 & \\
1911 & 2.222 .300 & $28,22 \%$ \\
1912 & 2.693 .600 & $21,21 \%$ \\
1913 & 2.857 .718 & $6,09 \%$ \\
1914 & 1.157 .885 & $-59,48 \%$ \\
1915 & 337.491 & $-70,85 \%$ \\
1916 & 375.121 & $11,15 \%$ \\
1917 & 487.195 & $29,88 \%$ \\
1918 & 424.971 & $-12,77 \%$ \\
1919 & 794.953 & $87,06 \%$ \\
1920 & 1.271 .030 & $59,89 \%$
\end{tabular}

Fonte: IBGE, Estatísticas históricas do Brasil: séries econômicas, demográficas e sociais de 1550 a 1988. 2. ed. rev. e atual. do v. 3 de Séries Estatísticas retrospectivas. Rio de Janeiro: IBGE, 1990.

Antes da guerra, os investimentos na indústria estavam em crescimento e chegaram a totalizar em 1913 cifra próxima a $£ 3$ milhões. Já no primeiro ano do conflito, a redução foi de aproximadamente $60 \%$ e as quedas continuaram expressivas que mantiveram as importações em até £ 500 mil até o final das hostilidades na Europa. Possivelmente a instabilidade que se instalou no Brasil a partir de julho de 1914 não foi compensada pelas oportunidades de negócios que o conflito na Europa trouxera por meio da ausência de concorrentes e da falta de ouro para as importações. Em pesquisas sobre a industrialização brasileira, Suzigan verificou que a limitação ao crescimento industrial brasileiro ocorreu também pela carência de máquinas e equipamentos que eram fabricados no exterior e que não 
puderam ser internados no Brasil. ${ }^{438}$ Nos arquivos da diplomacia britânica sobre o Brasil não há compêndio específico sobre investimentos estrangeiros ou de capital nacional na produção industrial do país.

Nas pesquisas realizadas junto aos arquivos britânicos, a questão industrial não apareceu como motivo de defesa pelo governo Wenceslau Braz nas operações desencadeadas no exterior para a obtenção de crédito. A quase totalidade do que o governo brasileiro tentou junto ao Reino Unido teve relação com exportações de commodities e com a importação de bens de consumo. O Brasil buscava manter as operações de comércio internacional de todas as formas porque exportações e importações regulares eram básicas para o funcionamento do próprio governo. A relevância do comércio importador pode ser mensurada pelo fato de que o Brasil mantinha um fundo em Londres destinado à liquidação de contratos de importação firmados com empresas estabelecidas em qualquer país. O comitê britânico encarregado de suprimentos durante a guerra exigiu investigação sobre solicitação de embarque de algodão de origem norte-americana, estocado na Inglaterra para atender demanda do Ministério da Guerra do Brasil, que pretendia utilizar como matériaprima na fabricação de uniformes. O que acendeu a dúvida na burocracia britânica era se os recursos brasileiros em Londres poderiam ser utilizados para a aquisição de produtos de um terceiro país, dada a situação de devedor do Brasil junto ao Reino Unido. $^{439}$

As modificações no mercado internacional compeliram a economia brasileira a procurar a diversificação no modo de atuar no comércio exterior. Valia tentar adicionar produtos à pauta de exportações ou procurar caminhos alternativos que levassem à concretização das vendas, tudo para fazer frente às reduções nos negócios de café e de borracha. A nova maneira de o Brasil agir no exterior chamava a atenção do governo britânico. Citando o Comitê Europeu para Borracha e Estanho, o Tesouro do Reino Unido alertou a chancelaria britânica que por motivos de conveniência técnica definida pelo Syndicat Professional des Caoutchouc Gutta Percha, a França preferia comprar borracha diretamente do Brasil e não mais por intermédio do Reino Unido. A verdade é que as facilidades obtidas pelo governo francês junto às

\footnotetext{
${ }^{438}$ Suzigan e Versiani, O processo brasileiro de industrialização: uma visão geral, p. 7-9.

${ }^{439}$ T 1/12208/7002, 18 fevereiro 1918, documento da Commission Internationale de Ravitaillement Londres, datado de 16 fevereiro 1918.
} 
autoridades brasileiras permitiam condições especiais de embarque que aumentavam em muito as vantagens no comércio direto com o Brasil. Esta situação desagradou o governo britânico, que suspeitou dos motivos alegados pelos franceses. Em carta enviada a Keynes, o Comitê Europeu para Borracha e Estanho emitiu opinião considerando "ridícula" a reinvindicação originada no Sindicato Francês. 440

O maior problema para o governo britânico era que, aparentemente, nada poderia ser feito para impedir esta manobra, uma vez que a borracha não estava na lista de produtos proibidos e a variedade brasileira era a única que cumpria especificações para utilização em aviões. O que o governo britânico não queria era ter que comprar o produto por intermédio da França. Esforços deveriam ser empreendidos para que a relação entre os produtores do Pará e os comerciantes britânicos fosse mantida. O caso suscitou grande movimentação entre departamentos britânicos encarregados da guerra e a diplomacia britânica, que tiveram que administrar a pressão do sindicato francês que não via sentido em passar a trabalhar com cotas ou com controle britânico na relação com a borracha Pará, como era conhecida a variedade brasileira. O que estava em jogo era a aquisição no atacado da borracha Pará e a distribuição com alta margem de lucro do produto entre os países da Tríplice Entente. ${ }^{441}$

Questionado sobre a equivalência entre a borracha Pará e a borracha plantation, o Comitê Europeu para Borracha e Estanho emitiu nota informando que não seria possível limitar importações da borracha com base em critérios puramente comerciais e que os dois produtos somente poderiam ter suas utilizações definidas por especialistas, ou seja, o Comitê decidiu não entrar na disputa entre os governos britânico e francês. $^{442}$

O mercado internacional da borracha foi radicalmente alterado a partir da década de 1910 com o escoamento da produção de colônias europeias no Sudeste Asiático que se firmaram como fornecedoras de borracha tipo plantation, distinta em preço e em qualidade da borracha produzida no Brasil conhecida como Pará ou borracha crua. A borracha asiática era ofertada a preços mais baixos que a variedade

\footnotetext{
${ }^{440}$ T 1/12208/34756, 07 setembro 1918. Carta do governo francês, Agence Financière de Londres, 15 julho 1918.

${ }^{441}$ T 1/12208/34756, 07 setembro 1918. Carta do Tesouro Britânico de 17 setembro 1918.

${ }^{442}$ T 1/12208/19696, 17 maio 1918, Carta do Rubber and Tin Exports Committee de 16 maio 1918.
} 
brasileira devido à quantidade muito superior que foi possível obter no sistema de cultivo intensivo, e também porque a borracha Pará tinha aplicações específicas em processos que requeriam qualidade superior, como na fabricação de aviões e em partes e peças de automóveis. Apesar da vantagem da borracha brasileira e do preço menor do tipo plantation, o mercado internacional passou a demandar o produto de acordo com a proximidade econômica e geográfica entre as zonas produtoras e as indústrias de artefatos de borracha, com os Estados Unidos preferindo o produto brasileiro e os europeus, a borracha das colônias na Ásia. ${ }^{443}$ Os obstáculos para o transporte marítimo advindos com a guerra aumentaram esta divisão do mercado, com os norte-americanos adquirindo do Brasil quantidades sempre superiores de borracha, enquanto que as exportações da borracha Pará para a Europa teve redução acentuada a partir de 1914, como mostra a Tabela 10.3.

Tabela 10.3 - Exportações de borracha tipo Pará, 1913-7 (toneladas)

\begin{tabular}{r|c|r|r|r}
\hline \multicolumn{4}{c}{ Destino } \\
1913 & Estados Unidos & \multicolumn{1}{c}{ Var. \% } & \multicolumn{1}{c}{ Europa } & Var. \% \\
1914 & 17.205 & & 22.165 & \\
1915 & 18.179 & 5,66 & 15.363 & $-30,69$ \\
1916 & 22.171 & 21,96 & 14.945 & $-2,72$ \\
1917 & 23.220 & 4,73 & 11.431 & $-23,51$ \\
Total & 26.000 & 11,97 & 13.000 & 13,73 \\
\hline
\end{tabular}

Fonte: T 1/12208/10949, 16 março 1918, carta do Rubber and

Tin Exports Committee de 06 março 1918.

O mercado norte-americano para a borracha Pará não era insignificante antes da guerra, mas foi ganhando vulto com o início dos conflitos na Europa. Logo em 1914 os Estados Unidos passaram a demandar quantidade maior do produto que os europeus, chegando em 1917 a representar o dobro das exportações para este mercado. A Tabela 10.3 identifica que os americanos ajudaram a compensar, em parte, a redução na demanda pelo produto brasileiro, principalmente durante o acirramento dos bloqueios navais organizados pela Tríplice Entente e o torpedeamento praticado em larga escala pelos alemães entre 1914 e 1917. O

\footnotetext{
${ }^{443}$ T 1/12208/10949, 16 março 1918, carta do Rubber and Tin Exports Committee de 06 março 1918.
} 
governo britânico concordou em adquirir 6.500 toneladas de borracha brasileira tipo Fina Sertão, no total de $£ 1,5$ milhão, valor que foi depositado diretamente na conta administrada pelo banco Rothschild em Londres para honrar compromissos da dívida externa do Brasil. ${ }^{44}$

Durante a guerra, quando a necessidade de suprimento se impunha, havia pressão do alto escalão do governo britânico para que fossem agilizados os trâmites de importações de produtos. Em relação ao Brasil, houve casos envolvendo borracha e castanhas que chegaram a ter prioridade de embarque. Devido à falta de navios, o governo britânico era regularmente obrigado a se envolver diretamente para conseguir disponibilidade logística, como ocorreu no início de 1918 para o embarque de 600 toneladas de borracha e 200 toneladas de castanhas. O estranhamento com a compra por castanhas durante a guerra se desfaz quando se considera que a oleaginosa serviu como importante fonte de proteína para as frentes de batalha. ${ }^{445}$

O equacionamento dos estoques no Reino Unido foi atingido antes mesmo do fim da guerra, significando um problema a mais para o Governo Brasileiro, ansioso por aumentar as exportações de commodities outras que não borracha, café e açúcar para os britânicos como forma de adquirir ouro. Documento interno do governo britânico mostra que o único carregamento no Brasil em quantidades expressivas que o Departamento de Transportes recomendava era o de feijões. ${ }^{446}$

A guerra gerou demanda por novos produtos, como o manganês, abundante no Brasil. Este metal é fundamental para a fabricação de ligas metálicas de ferro e de aço, tão importante para a indústria durante a guerra que foi alvo de disputa entre os Estados Unidos e o Reino Unido para a aquisição do produto no Brasil. A proximidade com o Brasil dava larga vantagem aos americanos nesta competição, o que motivou intervenção direta do Ministro de Munições do Reino Unido, Winston Churchill, nas negociações, principalmente após investigações revelarem que o manganês que havia recentemente sido descoberto nos Estados Unidos era inferior ao brasileiro. Se nada fosse feito para chamar a atenção do Governo Brasileiro, a

\footnotetext{
$444 \mathrm{~T}$ 1/12208/8661, 01 março 1918, document secreto do Trade and Treaty datado de 25 fevereiro de 1918.

${ }^{445}$ T 1/12208/18356, 08 maio 1918, Carta do FO para a Delegação Britânica no Brasil de 02 maio 1918.

${ }^{446}$ T 1/12208/9325, 08 março 1918, memorando do Ministério dos Transportes datado de 05 março 1918.
} 
totalidade da produção de manganês seria destinada aos norte-americanos. ${ }^{447}$ Manganês de qualidade equivalente ao brasileiro era encontrado na Índia, mas em quantidade que exigiria a manutenção do suprimento a partir do Brasil. Uma possível solução era o Reino Unido ganhar prioridade na comercialização do minério brasileiro, mas isto exigiria abandonar a estrutura montada na Índia e na Costa Oeste da África, igualmente produtores do minério.

De maneira paralela, o governo britânico decidiu iniciar uma campanha que modificou a situação das minas de minérios no Brasil, especialmente na região de São João Del Rey em Minas Gerais. São João passou a registrar elevado número de casos de disputa de propriedades que antes de 1914 estavam abandonadas, como a mina Capoeirinha, localizada próxima de terras pertencentes a Puncharde \& Company, relacionada ao Bank of Scotland e que agora estava sendo requisitada por empresa de capital alemão, como acreditava o corpo diplomático britânico. O plano da Delegação Britânica era encontrar o verdadeiro proprietário da Capoeirinha e negociar a comprar antes de provável investida formal de empresa alemã. As invasões de terras com manganês aumentaram substancialmente e estavam ameaçando propriedades da empresa Morro Velho, uma das maiores mineradoras do mundo, pertencente à empresa britânica Saint John Del Rey Mining Company. A área na qual estava localizada a empresa Capoeirinha passou a ser motivo de disputa entre grupos internacionais interessados em uma mina que possuía manganês a quatro quilômetros da estação ferroviária São Bento. Investigações do Governo Britânico descobriram que Caio Monteiro, advogado com base no Rio de Janeiro, havia se instalado na região como representante de empresa alemã com o propósito de tomar posse da área que ainda pertencia à empresa Capoeirinha, com aparente anuência das autoridades locais, especialmente do município de Santa Bárbara. ${ }^{448}$

Ao final do século XIX, vastas áreas na região de Itabira-MG foram adquiridas por empresas de capital britânico. Com a queda no preço de minérios como o manganês, muitas destas antigas minas estavam abandonadas ou somente mantidas por prepostos das empresas britânicas. Como o início da guerra e a alta no

447 T 1/12208/8355, 27 fevereiro 1918, documento do Ministry of Munitions of War datado de 26 fevereiro 1918.

448 "Manganese property in Minas Geraes - Asks enquiries as to whereabouts of British owners". FO 371/3168/113883, 27 junho 1918, p. 142-148. 
valor do manganês, o governo britânico decidiu localizar os herdeiros dos proprietários originais com o intuito de tomarem posse destas terras ou vendê-las a empresas britânicas interessadas na exploração do minério. Este era o caso da propriedade conhecida como Brucutu, pertencente à National Brazilian Mining Company que esteve em atividade entre 1869 e $1887 .{ }^{449}$

Para suprir a falta de moeda conversível, o governo brasileiro pressionou o Reino Unido durante a guerra para que fossem autorizadas exportações brasileiras para a montagem de estoques na Europa, situação que deixou os números das vendas brasileiras inflados. Em período de paz, muito provavelmente o Brasil teria exportado menos do que ficou registrado. As tratativas brasileiras para forçar negócios aconteceram até mesmo quando o comércio internacional para o país já estava em estágio comparativamente mais livre. Na parte final da guerra não havia a necessidade da volta das intrincadas estratégias da fase mais aguda das restrições impostas pela lista de exceção. Em carta à chancelaria britânica, com cópia para Keynes, Lionel Rothschild resumiu as possibilidades de bons negócios que poderiam ser realizados ao final de 1917 com o Brasil. O momento era propício porque o país, com déficit em ouro, estava ansioso para entrar em nova fase no comércio exterior, agora que a neutralidade fora substituída pela declaração de guerra aos impérios centrais. Rothschild elencou os produtos que poderiam ser exportados em larga quantidade, como feijão tipo mulatinho, arroz, couro seco e salgado, minério de manganês, além das commodities usuais como açúcar e borracha. ${ }^{450}$

Rothschild informou que o café não foi oferecido porque já era bastante evidente que tão cedo o governo britânico não liberaria a entrada do produto no Reino Unido, dados os estoques que se elevaram ao longo da guerra devido às diversas negociações que foram executadas para aliviar o estrangulamento externo brasileiro por meio de exportações de café. A tonelagem necessária ao transporte desta grande quantidade de produtos ganhou viabilidade com o arresto dos navios alemães que se encontravam nos portos brasileiros e que agora, com o fim da neutralidade, poderiam ser utilizados pela marinha mercante. ${ }^{451}$ As exportações de

\footnotetext{
449 "Minig properties in Minas Geraes - Calls attention to trespass on British mining properties by other prospectors", FO 371/3168/113883, 27 junho 1918, p. 149-155.

${ }^{450} \mathrm{~T}$ 1/12208/4887, 04 fevereiro 1918, carta de Lionel de Rothschild endereçada a Bonar Law do Tesouro Britânico datada de 08 novembro 1917.

${ }^{451}$ Ibidem.
} 
açúcar brasileiro estavam tão elevadas no início de 1918 que o Reino Unido decidiu diversificar as fontes de suprimentos e passou a considerar importações mais elevadas de Cuba. ${ }^{452}$

O problema foi convencer Keynes das vantagens desta operação para os cofres britânicos. Após longa espera, Keynes rejeitou a totalidade do acordo alegando que não havia naquele momento necessidade de aumentar o estoque de suprimentos estratégicos ou de modificar as aquisições de outros países, concorrentes do Brasil. A única liberação que o Tesouro Britânico pretendia realizar para o Brasil era o valor do aluguel dos navios alemães, estimado em $£$ 90.000/mês. ${ }^{453}$

O fim da neutralidade brasileira significou para o Brasil liberdade para negócios com outros países e, a partir do segundo semestre de 1917, foram iniciadas conversações com o governo francês que para a venda de café e de suprimentos diversos. Estas transações chamaram a atenção do mercado, fazendo Lionel Rothschild estimar que os contratos pudessem alcançar "muitos milhões de francos franceses". Na análise dos banqueiros britânicos, estes recursos não poderiam ser liberados diretamente por Paris sem consulta prévia ao Tesouro Britânico, pois os acordos entre os aliados da Entente obrigavam que as decisões fossem compartilhadas quando os valores envolvidos fossem elevados. ${ }^{454}$ Além destas considerações, o Brasil não estava livre para fazer negócios internacionais sem considerar a conta da dívida externa que era administrada pelos Rothschilds. Para comércio com outros países que não o Reino Unido, o Brasil deveria atentar para o fato de os que créditos brasileiros estavam vinculados ao escrutínio do Tesouro Britânico, conforme regras estabelecidas em telegrama anexado à carta de Lord Rothschild endereçada ao presidente do Brasil. ${ }^{455}$

Em mensagem de 1918, Wenceslau Braz destacou o aumento das exportações de produtos que ganharam impulso com a guerra e conseguiram reduzir os problemas

\footnotetext{
${ }^{452}$ T 1/12208/6532, 14 fevereiro 1918, memorando do Royal Commission on the Sugar Supply datado de 12 fevereiro 1918 .

${ }^{453}$ T 1/12208/4887, 04 fevereiro 1918, carta de John Maynard Keynes para Lionel Rothschild datada de 10 dezembro 1917.

454 Em telegrama de Henry Lynch, integrante da Delegação Britânica no Rio de Janeiro, há informação que a operação que o governo francês estava discutindo com o Brasil envolvia valor próximo de 110 milhões de francos. T 1/12208/4887, 04 fevereiro 1918, telegrama assinado por Henry Lynch em dezembro 1917.

${ }^{455}$ T 1/12208/4887, 04 fevereiro 1918, carta de Lionel de Rothschild endereçada a Bonar Law do Tesouro Britânico datada de 16 novembro 1917.
} 
com a redução nos preços do café e da borracha. Estes produtos, que o governo classificava como mercadorias novas, como carne enlatada, começaram a ser exportados em 1914 e alcançaram perto de 72.000 contos de réis em 1917. O manganês não fazia parte deste grupo de mercadorias novas porque houve exportações do minério antes de 1914, mas em total tão reduzido que os 57.234 contos obtidos em 1917 podem ser considerados como resultado das mudanças da guerra. $^{456}$

Tendo por base relatório do armador britânico Alfred Booth \& Company, especializado no comércio com a América do Sul, o governo do Reino Unido divulgou documento no qual expressou aprovação ao desempenho dos empresários brasileiros que demonstraram habilidade em adaptar procedimentos e recursos no sentido para atender as oportunidades de novos negócios propiciados pela guerra, colaborando de maneira valiosa para os esforços da causa dos países aliados. Para demonstrar as mudanças na pauta de exportações do Brasil, o Tesouro Britânico reproduziu dados preparados pelo armador, que formam a Tabela 10.4. Nela estão destacados em negrito os produtos brasileiros que teriam tido exportações beneficiadas durante a guerra.

Tabela 10.4 - Total de exportações do Brasil entre janeiro e setembro, comparação 1914 e 1917.

1914 Tonelada $£$ (mil)

Produto

Açúcar

Algodão

Arroz

Batatas

Borracha

Cacau

Café

Carne congelada

Carne seca

Cera

Couros

Diversos

\begin{tabular}{|r|r|}
$\mathbf{1 0 . 1 3 6}$ & $\mathbf{9 3}$ \\
29.239 & 1.805 \\
$\mathbf{0}$ & $\mathbf{0}$ \\
$\mathbf{0}$ & $\mathbf{0}$ \\
$\mathbf{2 5 . 5 7 2}$ & $\mathbf{5 . 4 6 7}$ \\
$\mathbf{2 7 . 9 9 3}$ & $\mathbf{1 . 3 1 2}$ \\
448.655 & 18.943 \\
$\mathbf{1}$ & $\mathbf{0 , 0 5}$ \\
$\mathbf{5}$ & 0 \\
$\mathbf{2 . 6 2 6}$ & $\mathbf{2 8 5}$ \\
$\mathbf{2 6 . 5 0 3}$ & $\mathbf{1 . 5 1 2}$ \\
$\mathbf{5 6 . 6 9 8}$ & $\mathbf{6 6 8}$
\end{tabular}

1917

\section{$£$ / total}

(\%)

\begin{tabular}{r|}
$\mathbf{0 , 2 7}$ \\
5,21 \\
$\mathbf{0 , 0 0}$ \\
$\mathbf{0 , 0 0}$ \\
$\mathbf{1 5 , 7 7}$ \\
$\mathbf{3 , 7 8}$ \\
54,63 \\
$\mathbf{0 , 0 0}$ \\
$\mathbf{0 , 0 0}$ \\
$\mathbf{0 , 8 2}$ \\
$\mathbf{4 , 3 6}$ \\
$\mathbf{1 , 9 3}$
\end{tabular}

To

Tonelada $£($ mil)

\begin{tabular}{l|l|}
$\mathbf{8 8 . 8 5 4}$ & $\mathbf{2 . 3 3 8}$ \\
\hline
\end{tabular}

$4.821 \quad 615$

$32.690 \quad 949$

3.243

26.717

38.321

471.652

50.470

3.598

3.205

27.510

38.209
$£$ / total

(\%)

\section{$\mathbf{5 , 2 4}$}

1,38

2,13

0,06

13,48

4,01

38,48

5,32

0,45

0,81

6,00

3,92

\footnotetext{
${ }^{456}$ Mensagem Presidencial 1918, p. 109.
} 


\begin{tabular}{l|r|r|r|r|r|r} 
Farinha de mandioca & $\mathbf{3 . 0 5 8}$ & $\mathbf{2 3}$ & $\mathbf{0 , 0 7}$ & $\mathbf{1 3 . 9 2 7}$ & $\mathbf{2 0 4}$ & $\mathbf{0 , 4 6}$ \\
Feijões & $\mathbf{3}$ & $\mathbf{0}$ & $\mathbf{0 , 0 0}$ & $\mathbf{7 5 . 8 3 5}$ & $\mathbf{1 . 7 0 4}$ & $\mathbf{3 , 8 2}$ \\
Frutas sortidas & 43.464 & 647 & 1,87 & 30.898 & 450 & 1,01 \\
Madeira para construção & $\mathbf{1 0 . 3 4 0}$ & $\mathbf{7 2}$ & $\mathbf{0 , 2 1}$ & $\mathbf{3 3 . 5 4 2}$ & $\mathbf{1 6 3}$ & $\mathbf{0 , 3 7}$ \\
Manganês & $\mathbf{1 5 7 . 2 3 0}$ & $\mathbf{2 3 3}$ & $\mathbf{0 , 6 7}$ & $\mathbf{4 1 5 . 7 2 5}$ & $\mathbf{2 . 2 8 9}$ & $\mathbf{5 , 1 3}$ \\
Mate & 42.967 & 1.234 & 3,56 & 40.181 & 1.111 & 2,49 \\
Milho & $\mathbf{0}$ & $\mathbf{0}$ & $\mathbf{0 , 0 0}$ & $\mathbf{1 7 . 3 3 7}$ & $\mathbf{1 4 7}$ & $\mathbf{0 , 3 3}$ \\
Óleos vegetais & $\mathbf{3 0 . 2 0 1}$ & $\mathbf{1 4 8}$ & $\mathbf{0 , 4 3}$ & $\mathbf{2 6 . 7 9 1}$ & $\mathbf{2 0 6}$ & $\mathbf{0 , 4 6}$ \\
Ouro & 3 & 326 & 0,94 & 3 & 369 & 0,83 \\
Peles & $\mathbf{2 . 1 6 7}$ & $\mathbf{4 5 8}$ & $\mathbf{1 , 3 2}$ & $\mathbf{2 . 5 7 4}$ & $\mathbf{9 6 4}$ & $\mathbf{2 , 1 6}$ \\
Tabaco & 25.025 & 1.446 & 4,17 & 15.637 & 742 & 1,66 \\
Total & 941.886 & 34.672 & 100,00 & 1.461 .740 & 44.617 & 100 \\
\hline
\end{tabular}

Fonte: 'The Foreign Commerce of Brazil', T 1/12208/4887, 04 fevereiro 1918, relatório de dezembro 1917 de Alfred Booth \& Company para o Foreign Office e JM Keynes.

Os dados divulgados pelo Tesouro Britânico compararam exportações realizadas pelo Brasil de janeiro a setembro de 1914 com igual período de 1917. A clara intenção do Governo Britânico era demonstrar que o café, produto vital para as relações do Brasil com o mundo, não passou por retração tão expressiva nas vendas ao exterior. As perdas que o Brasil tanto alardeava e fazia figurar como elemento central nas discussões com o governo britânico, diretas ou por intermédio dos banqueiros das casas Rothschild e Schröder, ainda escondiam o fato de o país ter conseguido mercado para produtos não tradicionais para as exportações do país, como carne congelada, carne seca, feijão, arroz e manganês.

Para estas avaliações e considerações, Londres utilizou dados de 1914, quando as exportações brasileiras já estavam reduzidas pelos efeitos da guerra, o que poderia transmitir a impressão que as perdas financeiras do país não haviam sido tão expressivas. Como os dados oficiais do Brasil foram publicados para o exercício completo, janeiro-dezembro, não é possível confrontar os números, mas é exequível verificar se há discrepâncias importantes entre os dados oficiais do Brasil, expostos na Tabela 10.5, e os divulgados pelo Tesouro Britânico.

Dos oito produtos mais exportados durante a guerra, o único para o qual os números não coincidem é o café, justamente o mais relevante da pauta. No informe britânico, as exportações sofreram pouca redução durante a guerra, algo em torno $£$ 1.000 mil. Os dados oficiais do Brasil expostos na Tabela 10.5 indicam que a queda foi muito mais expressiva se analisados os dados referentes a 1913, quando as vendas 
somaram perto de $£ 41.000$ mil e pioram ainda mais se considerado o total de $£$ 46.500 mil de 1912. Como as exportações de café em 1917 foram de $£ 23.000$ mil, fica patente a preocupação do governo brasileiro em se manifestar por meio das inúmeras tentativas de obtenção de crédito junto aos banqueiros e ao governo do Reino Unido. ${ }^{457}$

Tabela 10.5 - Quantidade, valor total e valor médio saca de café (60 kg) exportado pelo Brasil, 1910 - 1920

\begin{tabular}{|c|c|c|c|c|c|c|}
\hline & $\begin{array}{l}\text { Quantidade } \\
\text { sacas - mil }\end{array}$ & Var. $\%$ & $\begin{array}{l}\text { Valor total } \\
\text { (£ mil) }\end{array}$ & Var. \% & $\begin{array}{l}\text { Valor médio } \\
\text { por saca }\end{array}$ & Var. $\%$ \\
\hline 1910 & 9.724 & & 26.696 & & 2,75 & \\
\hline 1911 & 11.258 & $15,78 \%$ & 40.401 & $51,34 \%$ & 3,59 & $30,72 \%$ \\
\hline 1912 & 12.080 & $7,30 \%$ & 46.558 & $15,24 \%$ & 3,85 & $7,40 \%$ \\
\hline 1913 & 13.268 & $9,83 \%$ & 40.779 & $-12,41 \%$ & 3,07 & $-20,25 \%$ \\
\hline 1914 & 11.270 & $-15,06 \%$ & 27.000 & $-33,79 \%$ & 2,40 & $-22,05 \%$ \\
\hline 1915 & 17.061 & $51,38 \%$ & 32.191 & $19,23 \%$ & 1,89 & $-21,24 \%$ \\
\hline 1916 & 13.039 & $-23,57 \%$ & 29.281 & $-9,04 \%$ & 2,25 & $19,02 \%$ \\
\hline 1917 & 10.606 & $-18,66 \%$ & 23.054 & $-21,27 \%$ & 2,17 & $-3,20 \%$ \\
\hline 1918 & 7.433 & $-29,92 \%$ & 19.041 & $-17,41 \%$ & 2,56 & $17,85 \%$ \\
\hline 1919 & 12.963 & $74,40 \%$ & 66.081 & $247,05 \%$ & 5,10 & $99,00 \%$ \\
\hline 1920 & 11.525 & $-11,09 \%$ & 40.456 & $-38,78 \%$ & 3,51 & $-31,14 \%$ \\
\hline
\end{tabular}

Fonte: Repertório Estatístico do Brasil - Quadros Retrospectivos, ano V - 1939-1940, Rio de Janeiro: Serviço Gráfico do Instituto Brasileiro de Geografia e Estatística, 1941.

O que mais preocupou o mercado foi a queda no preço do café que atingiu metade do valor em libras por saca exportada em 1915, ano no qual foi embarcada a maior quantidade do produto entre 1910 e 1920. O valor total obtido com o produto em 1913 somente foi superado ao final da guerra, como mostra a Tabela 10.5. A análise dos dados dos principais produtos exportados no período indica que foi possível compensar as perdas nos valores obtidos em libras esterlinas com outros produtos, mas estes produtos não puderam ser utilizados como garantia nas operações internacionais. Nos documentos analisados, a única opção ao café que os banqueiros internacionais aceitavam eram as rendas da alfândega, mas a ligação com o café persistia porque a redução nas vendas do café afetariam as receitas com os tributos aduaneiros. Neste sentido, as vendas somadas dos outros produtos, mesmo ultrapassando as do café, não tiveram o mesmo impacto macroeconômico. Foram

457 'The Foreign Commerce of Brazil', T 1/12208/4887, 04 fevereiro 1918, relatório de dezembro 1917 de Alfred Booth \& Company para o Foreign Office e JM Keynes. 
exportações excepcionais, que ajudaram a recompor as perdas financeiras absolutas com o café, mas não serviram para a concessão de crédito, elemento fundamental nas operações de comércio exterior. Não fez parte das atividades no setor externo brasileiro obter vantagens com estas exportações esporádicas, e não teria sido viável convencer um exportador europeu de insumos a aceitar lotes de arroz ou feijão como garantia do negócio.

Conclusão

A statutory list foi utilizada pelo Reino Unido como forma de bloquear recursos para a Alemanha. O problema foi mensurar os efeitos que a lista de exceções poderiam causar aos negócios britânicos. O país necessitava de recursos para enfrentar as restrições e gastos extraordinários da guerra. Isto explica a grande estrutura montada em Londres para administrar a lista de exceções. A ideia era dificultar a entrada e a saída de empresas da lista.

O governo britânico utilizou a statutory list como desculpa para praticar ampla ingerência nos negócios internos do Brasil. Em alguns casos, a sociedade identificou nestes atos britânicos desrespeito à soberanias brasileira. Agentes britânicos tinham autorização do governo brasileiro para verificar dados de comércio exterior e de investimentos de capital estrangeiro no Brasil.

O Brasil aceitou as regras da lista de exceções como qualquer país primárioexportador faria. Desobedecer a statutory list levaria o país a ficar sem opção de transporte internacional. Eliminaria as chances de efetivar importações e exportações porque os mercados ligados aos países da Entente ficariam inacessíveis. As regras da lista de exceções não foram aplicadas a todos os países de maneira indistinta. Os Estados Unidos tiveram liberdade praticamente absoluta em negociar os seus produtos no mercado internacional. Além de ter dependência menor do comércio exterior, o que modificava as regras para as empresas norte-americanas era o fato de o país ter sido o maior credor do Reino Unido durante a guerra. O financiamento que os Estados Unidos propiciaram ao Reino Unido foi fundamental para os britânicos enfrentaram a guerras. A questão que se coloca e que será discutida no próximo capítulo é que os recursos que o Tesouro norte-americano enviou ao Tesouro britânico durante a guerra significaram algo maior. Estava acontecendo, durante a 
Primeira Guerra Mundial, a passagem do poder na economia internacional, com amplas consequências para a economia brasileira. 


\section{Capítulo 11 - Ascensão dos Estados Unidos na economia internacional: economia brasileira no novo mainstream}

Estados Unidos entraram na guerra porque o Império Alemão não respeitou acordos de não agressão. Os alemães afundaram navios mercantes que eram de interesse para a economia americana, forçando o presidente Woodrow Wilson a declarar guerra à Alemanha. Os Estados Unidos não queriam participar da guerra. $\mathrm{O}$ país acreditava que as questões europeias seriam resolvidas da melhor maneira para os negócios americanos. A mudança na posição alemã foi explicada por Berlim como necessária para derrotar o Reino Unido de maneira mais rápida.

Os ataques alemães contra interesses britânicos causavam problemas sérios aos cofres do Reino Unido. Se a esta conta forem adicionados os gastos que o país tinha com a guerra, o problema fica ainda mais grave. Para poder suportar a guerra e manter a economia ativa, o Reino Unido entrou em acordo com os Estados Unidos e passou a receber empréstimos que ficaram conhecidos como "Empréstimos da Liberdade".

O Reino Unido tinha urgência em receber estes recursos porque o Tesouro britânico não conseguia mais obter financiamento pelos meios regulares. Os recursos eram transferidos semanalmente dos Estados Unidos para os cofres britânicos. Os valores eram expressivos, mas não se transformaram em dívida. O país tinha que liquidar os contratos no curto prazo. As garantias oferecidas pelos britânicos envolveram investimentos britânicos nos Estados Unidos e em países como o Brasil.

Os "Empréstimos da Liberdade" se transformaram em títulos comercializáveis em praças internacionais. A imprensa paulista noticiava a chegada de novos lotes destes títulos que poderiam ser adquiridos nos principais bancos da cidade. A relação do Brasil com os Estados Unidos não ficou restrita a estes papéis. Ao assumir o financiamento da economia britânica, os Estados Unidos estavam modificando as regras da economia internacional durante a guerra. A economia brasileira sentiu os efeitos desta mudança antes mesmo do cessar fogo na Europa. 
Seção 11.1 - A guerra e a acumulação de capital nos Estados Unidos.

Os Estados Unidos tentaram ao máximo ficar fora da Primeira Guerra Mundial. A decisão pela declaração de guerra ao Império Alemão ocorreu somente após Berlim romper com o "Compromisso Sussex" - acordo firmado com os Estados Unidos que previa o fim dos ataques a navios de passageiros e a permissão para a tripulação de navios cargueiros abandonar as embarcações antes de qualquer ação bélica. Em convenção de guerra realizada em janeiro de 1917, o Kaiser Guilherme II foi convencido que o Reino Unido seria derrotado em seis meses se os submarinos empregassem artilharia máxima contra qualquer navio em rota que envolvesse interesses britânicos. De nada adiantaram os protestos do chanceler alemão Theobald von Bethmann-Hollweg que acreditava que esta medida colocaria os Estados Unidos na guerra. Foi precisamente o que ocorreu em abril de 1917, após falharem novas negociações diplomáticas. ${ }^{458}$

No Congresso, Woodrow Wilson abriu o discurso com a frase que ficaria eternizada: "We are fighting for what we believe and wish to be the rights of mankind and for the future peace and security of the world" - listou as necessidades que a guerra imporia: alimentos e vestuário em escala muito elevada para suprir o país e os aliados. As fábricas deveriam ser colocadas em produção máxima para tecidos, carvão para os navios e para a as indústrias, aço para a fabricação de armamentos e munições, trilhos para estradas de ferro em substituição aos materiais europeus que se encontravam desgastados, locomotivas e toda espécie de produto que Reino Unido, França, Itália e Rússia não podiam mais suprir por meios próprios. O lema nas empresas deveria ser "small profits and quick service". ${ }^{459}$

A entrada dos Estados Unidos na guerra era vista como o elemento vital para a solução rápida do conflito por conta do potencial econômico do país. Esta imagem de que o país ainda era de poder "potencial" com "reservas inigualáveis" como traziam as matérias dos jornais, mudaria após a declaração de guerra. ${ }^{460} \mathrm{Em} 1917$, o presidente Wilson já era chamado de o "chefe da democracia do mundo inteiro". ${ }^{4}$

\footnotetext{
${ }^{458}$ U.S. Department of State. Office of the historian: U.S. entry into World War I, 1917. https://history.state.gov/milestones/1914-1920/wwi

459 "President Wilson's address to his fellow countrymen", FO 115/2345, 16 abril 1917, p. 112-5.

${ }^{460}$ O Estado de S. Paulo, 9 fevereiro 1918, p. 1.

${ }^{461}$ O Estado de S. Paulo, 19 abril 1918, p. 1.
} 
Como forma de postergar o envio de tropas às frentes de batalha, os Estados Unidos entraram em acordo com o Reino Unido para a concessão de empréstimos destinados ao financiamento das atividades militares e econômicas dos britânicos. A forma pela qual os recursos foram solicitados seguiu um padrão: o Tesouro Britânico apresentava pedido de empréstimo com garantias ao Tesouro dos Estados Unidos, que levava a solicitação ao Congresso para autorização. Por vezes, o Tesouro norteamericano solicitava ao Congresso aprovação prévia de pacote de ajuda ao Reino Unido para liberação semanal de valores. Para cada um dos lotes de títulos houve negociações isoladas, sempre mencionando $\mathrm{o}$ ato aprovado no Congresso Americano. $^{462}$

Os trâmites de liberação de recursos para o governo britânico foram estabelecidos logo na primeira solicitação para empréstimo de US\$ 200 milhões, ocorrida a 24/04/1917. Nesta mesma data, o Congresso norte-americano aprovou as diretrizes para a concessão de recursos aos países aliados até o final da guerra, recursos que ficaram conhecidos como "Liberty Bonds", ou "Empréstimo da Liberdade", como os jornais no Brasil se referiam a estes títulos de financiamento. ${ }^{463}$

Estes recursos foram financiados com base na grande quantidade de ouro que os países europeus enviavam desde o início da guerra aos Estados Unidos para o pagamento de suprimentos. A quantidade de ouro que entrou nos Estados Unidos permitiu aos bancos norte-americanos oferecer os títulos do "Empréstimo da Liberdade" ao público em geral, em diversas praças, como se viu em São Paulo ao longo de $1918 .^{464}$

Os termos utilizados pelo governo britânico na solicitação dos empréstimos, bem como a forma pela qual se desenrolaram as negociações, demonstravam o grau

\footnotetext{
${ }^{462}$ FO 115/2345/U.S. Loans, 24 abril 1917, p. 274-5.

463 Para detalhamento do primeiro empréstimo no formato "Liberty Bonds", ver: FO 115/2345/U.S. Loans, 24 abril 1917, p. 268.

Para exemplo de como a imprensa brasileira noticiava a entrada de recursos norte-americanos no financiamento dos aliados, ver: "A guerra nos Estados Unidos - O $4^{\circ}$ empréstimo da liberdade", $O$ Estado de S. Paulo, 26 setembro 1918, p. 6.

${ }^{464}$ Nas palavras do Federal Reserve, os conflitos na Europa amealharam tanto ouro para os Estados Unidos que foi necessário redefinir o papel do FED na economia norte-americana e na economia internacional. Informações sobre o FED e sobre "Liberty Bonds" durante a guerra, ver: "Federal Reserve Role During WWI".

Site: http://www.federalreservehistory.org/Events/DetailView/17

Para exemplo de anúncio do "Empréstimo da Liberdade" no Brasil, ver: "Terceiro Emprestimo da Liberdade - \$3.000.000.000”, O Estado de S.Paulo, 06 abril 1918, p. 1.
} 
de necessidade de recursos em que estava o Reino Unido. O país ofereceu garantias tais que permitissem a liberação dos recursos no dia seguinte à oficialização da solicitação. A aprovação deste primeiro pedido ocorreu de maneira rápida, em trâmite sumário no Congresso americano que exigiu apenas juros de 3\% ao ano e um certificado de endividamento emitido pelo Tesouro Britânico. ${ }^{465}$

No mês de maio de 1917, houve nova solicitação de empréstimo, desta vez em duas parcelas: US\$ 100 milhões para o início de junho e US\$ 85 milhões para o final do mesmo mês. Foram tantos e tão volumosos os empréstimos que se fez necessário organizá-los na Figura 11.1, que contém os recursos liberados pelo Tesouro Americano entre abril de 1917 e fevereiro de 1918.

Figura 11.1 - Empréstimos do Tesouro dos Estados Unidos para o Tesouro do Reino Unido, parciais 1917 e 1918 (US\$ mil)

\begin{tabular}{|c|c|c|c|c|c|}
\hline 1917 & & $\begin{array}{l}\text { Responsável } \\
\text { Tesouro } \\
\text { Britânico } \\
\end{array}$ & Data & & $\begin{array}{l}\text { Responsável } \\
\text { Tesouro } \\
\text { Britânico } \\
\end{array}$ \\
\hline $\begin{array}{l}25 / \mathrm{abr} \\
05 / \mathrm{ma}\end{array}$ & 200.000 & C. Spring Rice & 06/out & 15.000 & R. Crawford \\
\hline $\begin{array}{l}\mathrm{i} \\
07 / \mathrm{ma}\end{array}$ & 25.000 & R. Crawford & 08/out & 40.000 & Lord Reading \\
\hline $\begin{array}{l}\mathrm{i} \\
14 / \mathrm{ma}\end{array}$ & 25.000 & C. Spring Rice & 16/out & 25.000 & Lord Reading \\
\hline $\begin{array}{l}\mathrm{i} \\
25 / \mathrm{ma}\end{array}$ & 75.000 & C. Spring Rice & 19/out & 25.000 & R. Crawford \\
\hline $\mathrm{i}$ & 75.000 & C. Spring Rice & 24/out & 30.000 & Lord Reading \\
\hline 09/jun & 75.000 & C. Spring Rice & 29/out & 25.000 & Lord Reading \\
\hline 14/jun & 25.000 & C. Spring Rice & $\begin{array}{l}31 / \text { out } \\
02 / \text { no }\end{array}$ & 25.000 & Lord Reading \\
\hline 19/jun & 35.000 & R. Crawford & $\begin{array}{l}\text { v } \\
\text { 09/no }\end{array}$ & 50.000 & Lord Reading \\
\hline 26/jun & 15.000 & R. Crawford & $\begin{array}{l}\mathrm{v} \\
16 / \text { no }\end{array}$ & 50.000 & R. Crawford \\
\hline 30/jun & 10.000 & R. Crawford & $\begin{array}{l}\text { v } \\
\text { 23/no }\end{array}$ & 55.000 & C. Spring Rice \\
\hline 02/jul & 25.000 & R. Crawford & $\mathrm{v}$ & 60.000 & C. Spring Rice \\
\hline 05/jul & 100.000 & C. Spring Rice & $01 / \mathrm{dez}$ & 65.000 & C. Spring Rice \\
\hline $\begin{array}{l}\text { 20/jul } \\
01 / \mathrm{ag}\end{array}$ & 85.000 & C. Spring Rice & 07/dez & 55.000 & C. Spring Rice \\
\hline o & 50.000 & C. Spring Rice & $14 / \mathrm{dez}$ & 50.000 & C. Spring Rice \\
\hline 09/ag & 50.000 & C. Spring Rice & $21 / \mathrm{dez}$ & 45.000 & R. Crawford \\
\hline
\end{tabular}


16/ag

23/ag

o

50.000

C. Spring Rice

1918

30/ag

50.000 C. Spring Rice

04/jan

65.000

R. Crawford

0

35.000

R. Crawford

11/jan

60.000

C. Spring Rice

$05 /$ set

40.000

C. Spring Rice

18/jan

30.000

R. Crawford

08/set

C. Spring Rice

25/jan

30.000

R. Crawford

$11 / \mathrm{se}$

C. Spring Rice

$31 /$ jan

65.000

R. Crawford

19/set 50.000 Lord Reading

01/fev

30.000

R. Crawford

24/set 35.000 Lord Reading

08/fev

60.000

R. Crawford

01/out 50.000 Lord Reading

$15 /$ fev $\quad 30.000$

R. Crawford

2.225 .00

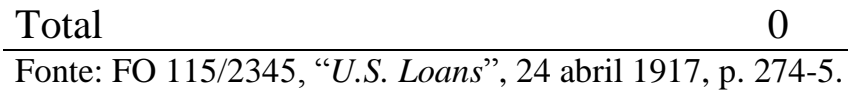

Após a decisão dos Estados Unidos em romper relações diplomáticas com o Império Alemão, a dependência do Reino Unido dos recursos repassados por Washington para financiar as operações do país durante a guerra fez com que as relações financeiras dos britânicos no exterior passassem a ter elevada correlação com as que eles mantinham com os Estados Unidos. Os dados da Figura 4.1 mostram que a contabilidade entre os dois países é indicativa que também a relação financeira do Brasil com Londres, principalmente a partir de abril de 1917, dependeu de recursos norte-americanos. A tendência era que influências mais proeminentes de Washington na política econômica brasileira se fizessem sentir antes mesmo do fim dos conflitos na Europa. ${ }^{466}$

A periodicidade das solicitações atendia ao fluxo de caixa britânico em clara demonstração de como o financiamento da guerra passou a funcionar a partir de 1917. Na prática, o Tesouro dos Estados Unidos transformou-se no Tesouro do Reino Unido. Isto explica porque os valores foram contabilizados semanalmente, em vez de um empréstimo global que atendesse a maior parte das necessidades britânicas estimadas para o curto prazo. Os trâmites eram por via rápida, bastando a assinatura do responsável pelo Tesouro Britânico. Os responsáveis eram funcionários da chancelaria

466 “U.S. Loans to Great Britain”, FO 115/2345, abril/maio 1917. 
britânica, notórios diplomatas britânicos alocados em Washington. A importância dos seus atos fez com que entrassem para a história da economia internacional durante a Primeira Guerra Mundial, caso de Cecil Spring Rice, embaixador britânico nos Estados Unidos durante a guerra ${ }^{467}$ e de Robert Crawford, responsável pelas relações com bancos norte-americanos, leia-se com o J. P. Morgan. A foto de McAdoo ${ }^{468}$ com os seus colegas britânicos quando da assinatura do primeiro empréstimo de US\$ 200 milhões ilustra à perfeição esta nova fase da economia internacional, espécie de registro simbólico do momento no qual se deu a passagem do poder global do Reino Unido para os Estados Unidos. ${ }^{469}$

Parecia não haver contestação possível ao domínio dos Estados Unidos. O orçamento britânico para 1918, por exemplo, dependeu em larga medida dos empréstimos concedidos pelo Tesouro americano. Bonar Law, ministro das Finanças do Reino Unido, divulgou que o total de adiantamentos realizados aos países aliados em 1917 havia sido de $£ 505$ milhões e que os repasses dos Estados Unidos ao Tesouro Britânico somaram £ 950 milhões. As finanças internas britânicas estavam suportando bem as dificuldades da guerra, analisou Law, mas o objetivo maior era parar de depender dos empréstimos americanos. Apesar de o imposto sobre os lucros da guerra ter arrecadado $£ 300$ milhões e de os tributos lançados para fazer frente aos custos da guerra terem aumentado a entrada de recursos em 66\%, o déficit para o exercício fechara em aproximados $£ 2.200$ milhões. Sem o suporte do Tesouro norte-americano, o financiamento da economia britânica seria impraticável. ${ }^{470}$

O ato do governo dos Estados Unidos autorizando a emissão de títulos do Tesouro estabelecia que a operação tivesse como único propósito atender a demanda da segurança e defesa nacional por meio da concessão de crédito a governos estrangeiros. Os reembolsos

\footnotetext{
${ }^{467}$ Sobre Cecil Spring Rice, ver: Site "The Telegraph - History": http://www.telegraph.co.uk/history/10088951/This-memorial-is-poetic-justice-for-Sir-Cecil-SpringRice.html

${ }^{468}$ William Gibbs McAdoo foi Secretário do Tesouro dos Estados Unidos durante a Guerra. Coube a McAdoo o plano de assistência aos aliados, o "Empréstimo da Liberdade". Sobre os atos de McAddo como Secretário do Tesouro, ver: Site "Washington State University - Secretary of the Treasury William Gibbs McAdoo".

http://kaga.wsulibs.wsu.edu/cdm4/results.php?CISOOP1=any \&CISOBOX1=Gibbs\&CISOFIELD1=C ISOSEARCHALL\&CISOOP2=all \&CISOBOX2=secretary+of+the+treasury+william+gibbs+mcadoo $\&$ CISOFIELD2=subjec\&CISOROOT=/clipping_II\&t=s\&CISOSTART $=1,21$

469 Sobre Robert Crawford, ver site: "National Magazine, vol. 46, abril-setembro 1917": http://www.mocavo.com/National-Magazine-Vol-46-Apr-to-Sep-1917-Volume-46/448956/175 Na página deste site está reproduzida a foto mencionada.

${ }^{470}$ O Estado de S. Paulo, 24 abril 1918, p.1.
} 
ao Tesouro dos Estados Unidos foram igualmente realizados de forma periódica. Não foi praxe transformar os repasses em dívida externa. Isto pode ser verificado em julho de 1917, quando o acumulado parcial de US\$ 550 milhões foi liquidado com juros de 3,5\% ao ano. As garantias negociadas entre os dois governos envolviam essencialmente ferrovias nos Estados Unidos que haviam sido construídas com capital britânico ou estavam em posse de empresas britânicas. Entravam como garantia secundária negócios de outros setores em território americano que operavam com capital de empresa sediada no Reino Unido. As informações dos burocratas britânicos sobre estes investimentos eram fundamentais para viabilizar as operações de socorro financeiro. A falta de respostas conclusivas do Reino Unido levou o Tesouro Americano a cobrar de maneira enfática empenho de Londres para que levantamentos sobre investimentos do Reino Unido em território americano fossem entregues sempre com urgência máxima. ${ }^{471}$

\section{Seção 11.2 - Estados Unidos e a nova economia internacional.}

O financiamento da economia britânica pelos Estados Unidos deu a Washington o direito de cobrar desempenho do governo britânico e a exigir explicações sobre o destino dos recursos. Como o Reino Unido continuasse a desempenhar o papel de financiador de última instância de vários países, foi natural que o Tesouro Americano demonstrasse repúdio por Londres estar repassando divisas dos Estados Unidos para outros aliados, como a Rússia que recebeu US\$ 160 milhões após o Ato de abril de 1917. O problema era considerado muito grave porque Londres não fez sequer negociações prévias com Washington antes de fechar acordo com os russos. ${ }^{472}$

Washington dizia que o fato de os compromissos terem sido firmados com Londres não permitia transferências a terceiros, mesmo que a responsabilidade final pelo pagamento continuasse com o Tesouro Britânico. O que os documentos demonstram sobre empréstimos a outros países realizados pelo Reino Unido é que o governo americano estava preocupado em perder a chance de fazer negociações diretas, impondo regras e salvaguardas específicas para cada país. Os interesses norte-americanos tinham que prevalecer sobre os britânicos. A partir deste caso com Moscou, os Estados Unidos decidiram estabelecer condições mais rígidas que definiram que o financiamento de aliados fosse dividido em duas partes: acordos com o Reino Unido seriam exclusivos para o

\footnotetext{
${ }^{471}$ FO 115/2345/U.S. Loans, 24 abril 1917, p. 278-81.

${ }^{472}$ FO 115/2406/U.S. Loans, 24 abril 1917, p. 21.
} 
atendimento do próprio país e das demandas de suas colônias e ex-colônias, com exceção do Canadá. Acordos de fornecimento de recursos para outros países aliados teriam que ser firmados diretamente com o Tesouro Americano. ${ }^{473}$

A dificuldade em adotar regras específicas para o financiamento dos aliados permitiu ramificações complexas de repasses de recursos que acabavam por deixar o Tesouro Americano como mero agente financeiro observador. Este foi o caso com a Bélgica, que devia US\$ 515 milhões ao Reino Unido, recursos que foram obtidos no Canadá por intermédio do Comitê Real de Munições. O governo americano utilizou este exemplo em diversos documentos para sensibilizar o seu parceiro britânico da seriedade com a qual o acordo deveria ser administrado. O risco era grande de o Congresso em Washington não aceitar as explicações britânicas sobre como recursos americanos foram parar em poder de empresas belgas, sem que nenhum aspecto desta transação tivesse sido examinado por qualquer departamento dos Estados Unidos. ${ }^{474}$

A questão do abastecimento de alimentos era outro grande problema. Quando o Reino Unido solicitava recursos ao governo americano para a aquisição de comida, o destino final dos valores deveria ser explicitado porque Washington não permitia que dinheiro americano fosse parar em fornecedores de cereais estabelecidos em um terceiro país. O Departamento de Estado norte-americano muito estranhava estas solicitações de alimentos e afirmava que o Reino Unido tinha plenas condições de atender suas necessidades nutricionais dentro dos limites geográficos de suas colônias, que o país era autossuficiente em quase todos os gêneros alimentícios e não era correto falar em "despesas de guerra" quando na verdade o que havia eram interesses difusos nas negociações com países com os quais Londres mantinha acordos comerciais e financeiros. ${ }^{475}$ Este era o caso do Brasil por conta das negociações de café e borracha, principalmente.

O governo americano estava tomando ciência na prática que as imbricações dos negócios britânicos eram fruto de décadas de acordos firmados com uma miríade de países, acordos em forma de redes que envolviam terceiros países. Foi o que se passou com a Itália. O país adquiriu aço do Reino Unido utilizando crédito concedido pelos Estados Unidos. Como se não bastasse o repasse indireto de recursos americanos para os italianos,

\footnotetext{
473 Ibidem.

${ }^{474}$ FO 115/2345/U.S. Loans, 24 abril 1917, p. 23

${ }^{475}$ FO 115/2345/U.S. Loans, 24 abril 1917, p. 24
} 
parte do aço que os britânicos obtinham com empresas americanas era destinado a repor vendas a outros países aliados. ${ }^{476}$

Afora a perda do poder nas relações internacionais quando repasses eram triangulados pelo Reino Unido, a economia norte-americana não tinha do que reclamar. Não deveria haver trégua na verificação das garantias e na cobrança do pagamento dos empréstimos aos aliados, mas o Tesouro americano calculou que o montante de recursos repassados era inferior aos gastos que estes países realizavam na aquisição produtos americanos. O balanço final era positivo e bastante saudável para a economia dos Estados Unidos. ${ }^{477}$ A continuidade dos repasses do Tesouro americano dependia do Congresso e este somente manteria os endossos se o retorno do capital investido fosse vantajoso para a economia do país.

A variável mais importante para a avaliação do retorno dos investimentos dependia da obtenção de taxa de câmbio satisfatória para o comércio com os Estados Unidos nos países que mais importavam produtos do país, como Reino Unido, França e Itália. O Tesouro americano concluiu que a solução passava pelo estabelecimento de uma organização financeira que Washington batizara de Allied Banking Corporation. Esta instituição teria filiais nos maiores parceiros comerciais do país e correspondentes em todos os países aliados ou neutros com exclusividade na compra e venda de moedas estrangeiras e nas operações de clearing das transações internacionais destes países, fossem negócios de caráter público ou privado. $\mathrm{O}$ objetivo de paridade cambial adequada seria obtido com a contabilização de todas as transações em divisas estrangeiras destes países, levando a emissão de balanços que teriam o poder de direcionar as entradas e saídas de recursos - por meio de transações em ouro, controles do comércio de commodities evitando movimentações desfavoráveis das taxas de câmbio de outras moedas frente ao dólar. $^{478}$

A forma pela qual a Allied Banking Corporation funcionaria foi exemplificada pelo Tesouro americano. Se um americano decidisse adquirir 10.000 francos em produtos suíços, ele deveria procurar a Allied Banking Corporation por meio de seu banco e trocar dólares pelo equivalente em francos suíços. A corporação financeira internacional deveria ter os 10.000 francos prontos para a operação, mas caso isto não se verificasse, bancos

\footnotetext{
${ }^{476}$ FO 115/2345/U.S. Loans, 24 abril 1917, p. 25

${ }^{477}$ FO 115/2345/U.S. Loans, 24 abril 1917, p. 27

${ }^{478}$ FO 115/2345/U.S. Loans, 24 abril 1917, p. 34
} 
suíços seriam acionados para suprir a transação, evitando especulações na taxa de câmbio. Se isto não fosse possível, transferências de ouro seriam colocadas na operação e os ajustes realizados de tal forma que o equilíbrio entre demanda e oferta fosse atingido de maneira rápida. $\mathrm{Na}$ avaliação dos Estados Unidos, se a tendência do câmbio era voltar um dia à posição de ao par, por que não agora? Era, em avaliação sumária, uma simples questão de ajustes cambiais e de um país que tivesse condições para tanto. A volta do poder de compra das moedas dos aliados era para William McAdoo, secretário do Tesouro dos Estados Unidos, uma questão de justiça para com as pessoas de países que deram suas vidas na guerra e agora mereciam ter uma moeda que pudesse satisfazer suas necessidades de produtos. ${ }^{479}$ Com a produção dos países da Entente voltada para a guerra, era de se esperar que as aquisições se dessem em artigos fabricados por empresas norte-americanas.

Representantes do governo britânico em Washington eram categóricos em afirmar que a necessidade de suporte financeiro dos Estados Unidos devia-se exclusivamente aos repasses de recursos que o Reino Unido efetuava a países neutros para garantir o apoio das sociedades destas nações à causa dos aliados. Como as críticas dos Estados Unidos aumentassem na fase final da guerra, a chancelaria britânica decidiu encomendar uma pesquisa estatística sobre as relações comerciais e financeiras entre o Reino Unido e os países neutros. O resultado demonstrou que o balanço desta relação era favorável a Londres e que não procedia reclamação do sistema financeiro americano sobre o financiamento de compras de países aliados em países neutros e que tanta carga adicional estava colocando sobre os bancos em Nova York. ${ }^{480}$

Como estratégia para calar os críticos da política econômica internacional do Reino Unido, foram apresentados dados das transações correntes do terceiro trimestre de 1917 com os principais países neutros que totalizaram aproximadamente $£ 21$ milhões a favor e $£ 5$ milhões contra o Reino Unido. Eram £ 16 milhões a receber somente dos países neutros, dos quais $£ 4,5$ milhões do Brasil, montante que o balanço mostra que foi composto basicamente pela conta de empréstimos. Em comparação com as transações com a Argentina, o saldo foi negativo para os britânicos em £ 3,6 milhões devido à conta de

\footnotetext{
${ }^{479}$ FO 115/2345/U.S. Loans, 24 abril 1917, p. 35.

${ }^{480}$ FO 115/2406, "Memorandum on the adverse balance of indebtedness as between the United Kingdom and certain neutral countries", outubro1918, p. 45-61
} 
comércio exterior que registrou saldo negativo de quase $£ 7$ milhões para Londres, principalmente por conta das importações de trigo. ${ }^{481}$

Estes dois países, Brasil e Argentina, serviam bastante bem ao propósito da contra argumentação da chancelaria britânica ao provar que as generalizações sobre a aplicação dos recursos do Tesouro dos Estados Unidos não eram válidas. Sem citar países, Londres afirmava que o ponto a ser analisado era o saldo final: perdia-se com a Argentina, mas ganhava-se com o Brasil. Do outro lado da discussão, o problema para Washington não era questão de superávit ou déficit do balanço de pagamentos do Reino Unido, mas a constatação que os recursos repassados semanalmente por Washington eram utilizados como elemento-chave dos interesses internacionais do capital britânico. Intui-se por este prisma que os Estados Unidos não viam realmente diferença entre emprestar recursos ao Brasil ou ter déficit comercial com a Argentina porque as duas situações aumentavam o poder de barganha do capital britânico nestes países, poder este patrocinado por recursos do Tesouro Norte-Americano. ${ }^{482}$

A preocupação do governo britânico em esclarecer suas movimentações financeiras internacionais foi resultado da observação de debates internos sobre a prática de financiar países neutros com recursos dos Estados Unidos. A chancelaria entendeu que se o próprio Tesouro do Reino Unido era abertamente contra estas operações é porque havia a necessidade de melhorar a comunicação com o sistema financeiro internacional. Diplomatas em Londres e em Washington trocaram muitos memorandos sobre a validade de recursos americanos financiarem a economia de outros países quando era notório que os Estados Unidos figuravam como o maior produtor mundial de alimentos. A decisão foi a de canalizar de pronto as importações dos aliados de matérias-primas e alimentos para os Estados Unidos. Como alternativa, em caso de impossibilidade norte-americana, os pedidos deveriam seguir para o Canadá como forma de ajudar o país a enfrentar dura desvalorização cambial. Nos diversos telegramas trocados entre os dois lados do Atlântico ficaram expostos os sinais de atrito e as diferentes maneiras de definir a melhor prática para a política econômica internacional. ${ }^{483}$

A aproximação dos governos do Brasil e dos Estados Unidos ocorria no meio desta disputa na economia internacional, com Londres e Washington decidindo como ficariam os

\footnotetext{
${ }^{481}$ FO 115/2406/U.S, Loans 1918, p. 56

482 Ibidem.

${ }^{483}$ FO 115/2406/U.S, Loans 1918, p. 75-81
} 
negócios no pós-guerra. Ao final de 1918, uma grande operação financeira para o Brasil estava em curso. O cerne da negociação era o pagamento pelos Estados Unidos de toda a dívida externa brasileira contraída junto a bancos britânicos e franceses. Seria um empréstimo com vencimento em 25 anos e que teria como garantias as receitas alfandegárias e a administração da Ferrovia Central e da Empresa Lloyd de Navegação. Domício da Gama, Ministro das Relações Exteriores, teria iniciado entendimentos com empresários norte-americanos quando ocupou o posto de embaixador em Washington $(1911-1918) .^{484}$

Muitos no Brasil receavam que as negociações com os banqueiros norte-americanos envolvessem garantias com base na alienação de estradas de ferro, da empresa de navegação Lloyd Brasileiro ou até mesmo dos recursos das alfândegas, as rendas aduaneiras. A humilhação estaria no fato de os Estados Unidos terem a intenção de utilizar o Brasil exclusivamente para liquidar garantias a empréstimos ao próprio país, mas também como mercado onde seriam liquidadas as garantias oferecidas pelo Reino Unido e pela França em operações de crédito que estas nações realizaram com recursos norteamericanos para custear as despesas da guerra. O problema estava em que parte destas garantias arrolavam ativos custeados com recursos brasileiros, como as estradas de ferro. Se estes investimentos não ocorreram com desembolso imediato de recursos brasileiros, a dívida estava contabilizada em nome do Brasil, dívida que deveria ser liquidada se as garantias europeias fossem executadas. ${ }^{485}$

Acreditando que as condições para o refinanciamento da dívida externa brasileira seriam mais vantajosas se realizadas com banqueiros norte-americanos, o Ministério da Fazenda passou a conduzir pedidos de socorro financeiro nos Estados Unidos. Domício da Gama, agora ex-embaixador em Washington, vinha de longa carreira na diplomacia quando teve a oportunidade de trabalhar com o Barão de Rio Branco e com Joaquim Nabuco, fatos que formaram em torno do diplomata uma reputação que não era facilmente atacada, como agora tentava $O$ Imparcial. ${ }^{486} \mathrm{O}$ jornal abordou tema bastante recorrente na época, o avanço do poder dos Estados Unidos. Expressando o que chamava de "dúvidas da sociedade brasileira", o periódico indagou porque o Brasil deveria trocar a experiência em tratar com as praças de Londres e Paris por uma "aventura" com bancos desconhecidos que

\footnotetext{
484 "Brazil and the United States", FO 371/3653/202153, 09 dezembro 1918. 485 Ibidem.

486 Domício da Gama, biografia divulgada pela Academia Brasileira de Letras: http://www.academia.org.br/academicos/domicio-da-gama/biografia
} 
tentariam vantagens extorsivas nas mais diversas áreas da economia brasileira. O Brasil tendia a sair destas negociações rebaixado em sua soberania. O jornal dizia que operação como a que se estudava em Washington somente faria sentido se o país estivesse sem base de negociação com os atuais credores ou se o sistema financeiro dos Estados Unidos oferecesse descontos no serviço ou no principal da dívida, o que não se verificava. ${ }^{487}$

As negociações que Domício da Gama começou em Washington repercutiram em Londres e Arthur Peel, chefe da diplomacia britânica no Brasil, foi instado a obter esclarecimentos a respeito. Após acionar contatos no Ministério da Fazenda, o representante britânico no Brasil identificou que havia mesmo uma movimentação no sentido de liberação de recursos norte-americanos e que o assunto estava centrado na Embaixada do Brasil em Washington. Não satisfeito, Peel foi procurar diretamente Domício da Gama que nada confirmou porque o assunto era somente um estudo que não seria levado adiante porque as condições estipuladas estavam fora de discussão. Buscando informações com os americanos, Peel descobriu que o Secretário das Finanças dos Estados Unidos tratou do tema em Washington e que um valor estava mesmo sendo estruturado para o Brasil. A intenção dos Estados Unidos era cobrir a falta que fariam ao Brasil os recursos que a França deixaria de enviar dada a impossibilidade de Paris manter as operações de charters com os navios que pertenceram à Alemanha e que estavam em poder do Brasil desde a declaração de guerra assinada por Wenceslau Braz. Citando Ruy Barbosa, o diplomata britânico afirmou que não parecia haver interesse na alta cúpula do governo brasileiro em efetuar uma guinada tão drástica nas relações do país com o sistema financeiro internacional. Se a França e o Reino Unido dessem maior atenção ao grande problema financeiro pelo qual o Brasil passava nesta fase final da guerra, o tema "Estados Unidos" seria definitivamente arquivado. ${ }^{488}$ Não se discutiu nesta ocasião como o Reino Unido obteria recursos para repassar aos cofres brasileiros sem utilizar a linha de crédito norte-americana.

$\mathrm{O}$ acordo que se estudava em Washington previa que o Brasil deveria transferir os navios alemães para operações charters nos Estados Unidos e que todos os interesses alemães nas praças brasileiras deveriam ser liquidados, especialmente os relacionados às atividades financeiras e comerciais. Empresas americanas deveriam participar deste

\footnotetext{
${ }^{487}$ Reprodução do jornal O Imparcial de 15 de dezembro de 1918 com a manchete “ Tributo de vassalagem", obtida em FO 371/3653/3969, 08 janeiro 1919, p. 129.

488 “Reported U. S. Loan to Brazil”, FO 371/3653/4904, 09 janeiro 1919, p. 140-142.
} 
processo de liquidação do capital germânico no Brasil e o país deveria colaborar de maneira mais efetiva na censura ao sistema postal. Em troca, os americanos comprariam até nove milhões de sacas de café, além de manganês e borracha nas quantidades possíveis. O café deveria ser $60 \%$ do tipo Santos padrão 4 . O acordo previa que a lista de exceções seria finalmente eliminada para o Brasil. O Tesouro norte-americano ficaria encarregado de assegurar o pagamento dos compromissos brasileiros com o exterior vencendo nos próximos doze meses e em valor limite de US\$ 40 milhões, tendo as sacas de café e o manganês como garantias. Seriam ainda liberados mais US\$ 10 milhões para gastos navais. Os bancos alemães a serem liquidados deveriam ser assumidos pelos Estados Unidos caso o governo daquele país conseguisse ampliar os recursos alocados na War Finance Corporation. $^{489}$

Apesar de toda esta movimentação e da discussão dos detalhes do acordo, o governo dos Estados Unidos informou a Londres por telegrama que nenhum acordo para empréstimo ao Brasil havia sido firmado, sem maiores explicações. As negociações que estavam em curso eram antigas, sem nenhum fato novo. Londres apurou que o governo norte-americano não assinaria nenhum acordo com o Brasil enquanto houvesse o risco do envolvimento de empresas dos países aliados europeus em negócios brasileiros. ${ }^{490}$

Tentando desvencilhar o Brasil das pretensões dos Estados Unidos, Londres incentivou a formação da Missão Comercial Brasileira ao Reino Unido que ocorreria no início de 1919. Por ocasião das inúmeras reuniões internas que abordaram a visita de empresários brasileiros, um panorama sobre as possibilidades de negócios com o Brasil foi traçado pela diplomacia britânica no que ficou conhecido como "Relatório Pell", em alusão a Arthur Peel, diplomata-chefe da Representação Britânica no Brasil. O ponto central do "Relatório" foram os riscos que o capital britânico passara a correr na etapa final da guerra por conta da agressiva campanha diplomática e comercial que os Estados Unidos desenvolviam na região ${ }^{491}$.

A doutrina Monroe servia de base para a propaganda pan-americana com a qual Washington pretendia juntar questões políticas, sociais e econômicas dos países latinoamericanos, significando aumento considerável de competição com os interesses

\footnotetext{
${ }^{489}$ FO 371/3653/25833, 05 fevereiro 1919, p. 232-34.

490 “Loan to Brazil”, FO 371/3653/25833, 05 fevereiro 1919, p. 222-9.

491 “Anglo-Brazilian commercial relations", FO 371/3653/89902, 17 junho 1919, telegrama assinado por W. S.Barclay, p. 367.
} 
britânicos. O governo britânico acreditava que no Brasil as chances de sucesso da Doutrina Monroe eram mais reduzidas do que nos outros países, porque as lideranças brasileiras, não importando o presidente que estivesse no comando, não aceitariam a possibilidade de o Brasil se transformar em um protetorado dos Estados Unidos. A base para esta interpretação Londres tirou do cuidado que Wenceslau Braz demonstrara ao romper com a Alemanha. O presidente brasileiro enfatizou na ocasião que o motivo da decisão contra Berlim foram as animosidades demonstradas pelo Império Alemão ao torpedear navios brasileiros. A diplomacia britânica entendeu que o que Brasil não queria, ao se distanciar da Alemanha, era sinalizar que o país estava pronto para estreitar relações com os Estados Unidos. Para os britânicos, esta passagem descrevia o repúdio latente que existia na sociedade brasileira quanto ao risco de o país se tornar sombra dos Estados Unidos. ${ }^{492}$

Contrariamente à percepção que tomava conta do mercado nacional e da diplomacia internacional, Londres interpretava este momento final da guerra como o de maior proximidade entre o Reino Unido e o Brasil. Mensagens presidenciais enalteciam a "prodigiosa" parceria entre os dois países, parceria que permitiria ao Brasil se desenvolver com ajuda do capital britânico, principalmente os recursos que seriam alocados na construção de ferrovias e de serviços públicos. Apesar destas esperanças, o governo britânico não deixou de registrar o avanço dos interesses dos Estados Unidos no Brasil, a começar pela entrada dos bancos daquele país que eram utilizados como estratégia para a ampliação do comércio entre as duas nações. Não eram apensas promessas de negócios. $\mathrm{O}$ carvão norte-americano já era uma realidade que chegava ao Brasil mais barato, resultado de operações casadas de importação e exportação que proporcionavam redução nos fretes. $^{493}$

Os entraves aos produtos norte-americanos eram muitos, de acordo com o "Relatório Peel". Havia falta de confiança do comerciante brasileiro nos produtos norteamericanos porque geralmente os fabricantes não permitiam testes gratuitos em seus produtos. Além disto, muitas empresas exportadoras norte-americanas já tinham fama de não utilizar a boa fé nos negócios. O que fazia os produtos americanos terem vantagem no Brasil, continuava o "Relatório", eram as contrapartidas que o mercado dos Estados Unidos oferecia na compra de café e borracha, dando acesso aos produtores brasileiros a um mercado muito maior do que o do Reino Unido. Na avaliação do governo britânico,

\footnotetext{
492 Ibidem, p. 368.

${ }^{493}$ Ibidem, p. 369.
} 
lutar contra o domínio norte-americano não parecia boa estratégia. O que deveria ser feito era entrar com força nos mercados antes atendidos pelas potências centrais, não medindo esforços na substituição dos antigos atacadistas alemães para os mercados de açúcar, carne, couro, tabaco, feijões e minerais em geral. ${ }^{494}$

Londres acreditava que o que o Brasil mais necessitava nesta fase final da guerra eram capital e força de trabalho. O problema era que a política econômica que há tempos o Brasil adotava tinha o poder de afugentar o capital privado britânico, que com o fim da guerra contava com opções muito mais seguras e rentáveis nas colônias britânicas. Os muitos casos de perdas de recursos no Brasil, que empresas britânicas tiveram que suportar devido a medidas econômicas, não seriam facilmente esquecidos. $O$ final da guerra mostrou ao governo britânico que os recursos naturais e as possibilidades de negócios no Brasil não suplantavam as mazelas da economia. A única esperança era uma grande reforma da estrutura financeira do Brasil. Sem isto, não haveria avanço econômico sustentável. A sugestão contida no "Relatório" previa a ampliação da influência dos bancos britânicos na administração do Banco do Brasil, por meio do qual seria possível alcançar a cúpula do poder executivo do país, impondo um direcionamento nitidamente britânico às finanças brasileiras. ${ }^{495} \mathrm{O}$ Banco do Brasil ficou especialmente conhecido no sistema financeiro britânico devido às muitas tentativas de obtenção de recursos, conforme abordado no Capítulo 6.

O "Relatório" propôs um plano no qual o governo britânico adquiriria 125.000 ações do Banco do Brasil que permaneciam sem emissão de um total de 350.000 ações. Estas ações deveriam ser adquiridas pelos Rothschilds, que conseguiriam desta forma estabelecer um representante da confiança deles no conselho de administração do Banco do Brasil. A facilidade dos Rothschilds no relacionamento com o governo brasileiro ajudaria muito no estabelecimento de uma ponte entre o representante britânico no Banco do Brasil e o Ministério da Fazenda. Esta seria a porta que permitiria estabelecer no governo brasileiro a reorganização das finanças do país seguindo preceitos britânicos de administração pública. Este novo direcionamento das finanças brasileiras seria fundamental para beneficiar o capital britânico no país, afastando de maneira peremptória os interesses norte-americanos. ${ }^{496}$

\footnotetext{
494 Ibidem.

${ }^{495}$ Ibidem, p. 370.

${ }^{496}$ Ibidem, p. 371.
} 
Estas medidas foram justificadas pelo "Relatório" como urgentes, em cenário de pós-guerra, quando milhares de súditos britânicos voltariam ao mercado e mais negócios teriam que ser gerados para que a sobrecarga de tributos necessários para as obrigações da guerra fosse aliviada. Toda e qualquer possiblidade de estabelecimento de monopólios deveria ser colocada em prática. $\mathrm{O}$ mercado de juta deveria ser o primeiro. O produto tinha fornecimento praticamente exclusivo da colônia indiana. Dominar todas as pontas do mercado de juta significava controlar os mercados de café, cacau e tabaco, não apenas no Brasil, mas na Europa e nos Estados Unidos. A ideia era usar o Brasil como laboratório. Se bem sucedido, esquema similar seria implantado na América Central, Venezuela, Peru, Equador e Chile atingindo os mercados de cacau e nitratos. Seria uma espécie de "arma" colocada nas mãos do governo britânico para dominar a América Latina. ${ }^{497}$

O momento indicava que o Brasil poderia absorver milhões de libras em capital novo necessários para atender população, que estudos indicavam poderia ser multiplicada por dez em poucos anos. Se os planos de encampação do Banco do Brasil e de monopólio da juta não se mostrassem exequíveis, a alternativa seria o governo britânico organizar um consórcio de bancos estrangeiros que atuavam no Brasil para que as reformas financeiras pleiteadas ganhassem vulto com o apoio dos países nos quais estes bancos estavam sediados, especialmente Estados Unidos, França, Itália e Portugal. O "Relatório" expunha que risco de rejeição das elites brasileiras a estas intervenções era baixo visto que a soberania do país não seria atingida. Os custos da guerra deveriam ser financiados sem trégua e por métodos criativos, inovadores, como os propostos. ${ }^{498}$

O "Relatório Peel" termina informando a Londres que após vasta experiência negociando com o Brasil, os problemas mais graves que o país apresentava eram:

1) Emissão de moeda sem lastro;

2) Falta de salvaguardas para as oscilações na taxa de câmbio;

3) Sistema tributário defasado;

4) Restrições às remessas de capital estrangeiro;

5) Regras obscuras na administração da concessão do sistema ferroviário;

Eram questões prementes e de grande obstáculo ao desenvolvimento econômico brasileiro e às possibilidades de lucro que o capital britânico poderia obter no Brasil. Para

\footnotetext{
${ }^{497}$ Ibidem, p. 371-3.

${ }^{498}$ Ibidem, p. 374.
} 
garantir a permanência no mercado local, Londres deveria atuar nestas questões, forçando por qualquer meio mudanças no governo brasileiro. ${ }^{499}$

O "Relatório Peel" foi levado para análise do Departamento de Desenvolvimento e Inteligência do Reino Unido. Dividido em cinco partes, com cópias controladas, a resposta oficial do governo britânico foi de desaprovação às propostas do diplomata-chefe no Brasil. Londres avaliou que o momento não era adequado para cultivar inimizades com as autoridades brasileiras - estava em curso a organização de uma grande visita comercial de empresários e políticos brasileiros ao Reino Unido - e os planos propostos poderiam ser entendidos como ameaças, obstruindo negócios vantajosos que já estavam em andamento. Havia ainda o risco de diminuição das chances para a solução de pendencias comerciais que envolviam valores substantivos. A questão da juta e a ponte para o controle dos mercados de café, cacau e tabaco dependia de improvável aprovação do governo da Índia porque os preços aos fornecedores locais certamente seriam reduzidos, forçando o governo britânico a oferecer preços mínimos de comercialização. A instituição de um monopólio envolveria controle e aparato similares aos utilizados na lista de exceções, algo muito inviável naquele momento. Controlar o mercado de juta poderia forçar os exportadores brasileiros a utilizar containers, abrindo espaço para redução no preço do produto. Isto levaria a ruína aos produtores indianos. A proposta mais viável parecia ser a do consórcio de bancos, assunto que Peel poderia continuar a estudar. ${ }^{500}$

Paralelamente aos planos britânicos de permanência no controle da economia brasileira, os movimentos da política interna norte-americana eram acompanhados com atenção aos detalhes pela sociedade brasileira, com nomes e informações dos interlocutores mais próximos do Presidente Wilson. ${ }^{501}$ Conhecido no Brasil como "Empréstimo da Liberdade", os recursos que os Estados Unidos liberavam para os aliados tinham os procedimentos acompanhados com atenção. As sessões de votação no Senado norte-americano eram acompanhadas com as transcrições das falas dos senadores, como ficou registrado quando da análise de mais um lote de empréstimos que totalizava US\$ 4,5 bilhões. ${ }^{502}$

\footnotetext{
${ }^{499}$ Ibidem, p.375-7.

${ }^{500}$ FO 371/3653/97768, 04 julho 1919, p. 384-8.

${ }^{501}$ O Estado de S. Paulo 12 fevereiro 1918, p.1.

502 O Estado de S. Paulo, 05 abril 1918, p. 2;
} 
Atos do governo norte-americano passaram a ter grande impacto na economia brasileira. Em setembro de 1918, o Departamento de Administração de Alimentos dos Estados Unidos iniciou campanha para a redução do consumo de café. O objetivo era liberar espaço nos navios para o envio das tropas e de infraestrutura para a guerra na Europa. O mercado estimou que tais medidas pudessem reduzir em até 50\% o consumo de café no país, permitindo que o estoque fosse suficiente para atender a demanda por vários meses antes que uma nova aquisição de fizesse necessária. O sucesso desta ação do governo americano tendia a ser similar ao verificado com o consumo de açúcar após forte campanha civilizatória, com graves consequências para a economia brasileira. ${ }^{503}$

Passada a guerra, a situação voltou ao normal em termos de logística para o café, mas o mercado para o produto, outrora nas mãos do capital alemão, se transformou em alvo do governo norte-americano. Relato do jornal Evening Sun sobre a escassez de café nos Estados Unidos foi publicado em forma de matéria realizada com base em pesquisas junto a grandes importadores e varejistas. Os prognósticos eram de aumento acentuado no preço do produto. O problema não era a falta de estoques nos Estados Unidos, mas sim o controle que as autoridades norte-americanas exerciam sobre o mercado. Os comerciantes não estariam dispostos a adquirir mais café do Brasil por falta de referência para os preços e por receio de não ter como repassar o custo do produto no curto prazo. ${ }^{504}$

A forma de financiamento aos países aliados que os Estados Unidos estavam empregando durante a guerra redundou na estruturação de um centro financeiro voltado aos negócios internacionais, que passou a servir também ao financiamento do comércio exterior norte-americano. Os empreendimentos industriais do país contariam no pósguerra com uma organização financeira capaz de fazer chegar às praças internacionais manufaturas de diversas áreas. ${ }^{505}$ Nove países da América Latina, incluindo o Brasil, demostraram interesse em assinar acordos comerciais com os Estados Unidos após a guerra. As negociações eram padronizadas para a região e visavam organizar o

\footnotetext{
503 “O café nos Estados Unidos”, O Estado de S. Paulo, 13 setembro 1918, p. 2.

504 “O café nos Estados Unidos”, O Estado de S. Paulo, 12 dezembro 1918, p. 2.

505 “A acção internacional dos Estados Unidos”, O Estado de S. Paulo, 03 setembro 1918, p. 2.
} 
comércio exterior dos Estados Unidos no novo cenário para a economia internacional que a guerra estava ajudando a estruturar. ${ }^{506}$

Assumindo seu novo papel de líder mundial, os Estados Unidos passaram a se preocupar com questões relacionadas indiretamente aos negócios internacionais e emitiram comunicados informando ações para estabilizar o governo na Rússia e para a reconstrução das nações que estiveram até a guerra sob domínio do Império AustroHúngaro. Na América Latina, os Estados Unidos preparavam o terreno para o estabelecimento de negócios que contariam com o dólar estabilizado pelo ouro acumulado como moeda de referência. ${ }^{507}$ Como recado ao comércio internacional, o governo americano adquiriu por US\$ 60 milhões todos os terrenos e instalações navais na Filadélfia, investimento que elevaria o país à categoria de proprietário do maior estaleiro do mundo. A ideia era não poupar esforços na demonstração de poder. Não poderiam sobrar brechas para nações oportunistas no mercado internacional. ${ }^{508}$

Conclusão

Os recursos que os Estados Unidos deslocaram para o Reino Unido tinham origem nas exportações norte-americanas para os países que estavam em guerra ou para países neutros. Eram recursos em volume que ultrapassava em muito as necessidades da economia americana. O país decidiu utilizar este ouro para internacionalizar suas empresas e criar novas regras para a economia internacional. Estas regras deveriam seguir pressupostos que permitiriam os Estados Unidos controlar os negócios internacionais em escala global.

Quando os empréstimos ao Reino Unido começaram, o Tesouro norte-americano assumiu, na prática, o controle da economia britânica e do financiamento dos negócios britânicos no mundo. Como credores, os Estados Unidos passaram a cobrar desempenho do Reino Unido na utilização destes recursos. Proibiram Londres de praticar, sem autorização, o financiamento internacional com recursos do Tesouro americano.

Apesar de colocar diversos entraves para a utilização dos empréstimos, a economia norte-americana foi mais do que recompensada com esta instituição dos

\footnotetext{
506 "Tratados assignados entre os Estados Unidos e as nações da América Latina”, O Estado de S. Paulo, 28 outubro 1918, p. 2.

507 “A política internacional dos Estados Unidos”, O Estado de S. Paulo, 13 novembro 1918, p.2.

508 "Os Estados Unidos adquirem o maior estaleiro naval do mundo", O Estado de S. Paulo, 30 novembro 1918, p. 2.
} 
empréstimos. Os recursos tendiam a voltar de maneira dupla para o país: como pagamentos dos empréstimos e como aquisição de produtos norte-americanos no mercado internacional. Estes recursos permitiram aos Estados Unidos estabelecer novas regras para a economia internacional por meio da criação de um banco internacional destinado, no início, aos negócios com os países aliados.

Os Estados Unidos estavam dispostos a colocar o Brasil na sua érea de influência de maneira definitiva. A estratégia era arcar com toda a dívida externa brasileira. O Brasil passaria a dever apenas para os Estados Unidos. O maior indicativo deste plano foi o de que o Brasil no pós-guerra não teria que se preocupar em manter negócios com a Alemanha ou com qualquer outro país. As novas regras para os negócios internacionais seriam estabelecidas pelos Estados Unidos. Indicativo deste fato foi o arquivamento pelo governo britânico de um audacioso plano da diplomacia britânica de afastar o Brasil dos interesses do capital americano. 


\section{CONCLUSÃO}

A escassez de ouro no mercado internacional provocada pela intensificação das Guerras Balcânicas foi um dos três fatores a alimentar uma grave crise econômica no Brasil porque o país estava habituado a contar com recursos externos como forma de sustentar os orçamentos públicos que já nasciam deficitários em ouro e em papel. Os déficits em ouro eram problemas potencialmente muito mais sérios que os déficits em papel, visto que aqueles dependiam de saldos positivos na balança comercial, de investimentos ou de empréstimo em moeda estrangeira conversível para ser financiados. Com a confirmação dos receios de que consequências macroeconômicas potencialmente muito negativas originadas nos Bálcãs pudessem chegar às principais potências europeias, os recursos externos foram contingenciados em seus países de origem. A Casa Rothschild, representante oficial da dívida externa brasileira desde os tempos do Império, deixou claro no início de 1913 que não seria mais possível acolher os pedidos do governo brasileiro por empréstimos e por fianças de operações de investimentos em ferrovias, principalmente.

Sem poder contar com a até então certa ajuda financeira internacional, restaria ao governo de Hermes da Fonseca a adoção de medidas que estimulassem as exportações para a entrada de ouro que atenderia, por sua vez, os compromissos em moeda estrangeira e as importações melhorando, consequentemente, a renda aduaneira, principal fonte de receitas em ouro e em papel. O problema foi que os principais produtos que o Brasil exportava no período, café e borracha, estavam passando por problemas que extrapolavam a crise nos Bálcãs e que resultaram em entradas menores de divisas ao longo de 1913.

As exportações de café estavam sob os auspícios do sistema estruturado pelo Convênio de Taubaté que previa controle dos preços do produto no mercado internacional por meio da administração dos estoques. O esquema também previa garantir retorno financeiro com uma taxa cambial favorável ao negócio em mil-réis, taxa esta definida em lei e administrada pela Caixa de Conversão. As mudanças nos negócios do café foram o segundo fator para a crise de 1913 no Brasil: os empresários do setor tiveram que se curvar às novas exigências do maior consumidor mundial do produto, os Estados Unidos, e liquidar os estoques reguladores em Nova York, e 
posteriormente na Europa, derrubando o preço do produto e diminuindo a entrada de ouro no Brasil.

O terceiro fator para a crise de 1913 foi o fim do domínio brasileiro do mercado internacional da borracha, produto com consumo exponencial no início do século XX. O produto atraiu, por isto, atenção, projetos e recursos ingleses, franceses e holandeses, especialmente, que tiraram da região Norte do Brasil a primazia em ditar preços e condições ao mercado. A atratividade do preço do produto em 1910 foi o ponto que faltava para o incremento de plantio e exportação no Sudeste Asiático, região que passou a apresentar condições de negócios mais vantajosas utilizando a mesma fonte produtora do látex, a hevea brasiliensis, e que rapidamente suplantou os volumes exportados pelo Brasil, derrubando preços e selando o fim do ciclo da borracha no país.

Este fator foi mais importante para a instalação da crise de 1913 no Brasil do que as mudanças ocorridas na forma de negociação do café porque a queda nos valores exportados da borracha foi vertiginosa, repentina, caminho sem volta, isto é, o mercado, os banqueiros, o governo, todos sabiam que não havia como frear a produção do oriente e que o país teria que conviver a partir de então sem os milhões de libras esterlinas que alimentavam a Caixa que, neste cenário de financiamento internacional escasso e de redução drástica de divisas, foi obrigada a encerrar as emissões de bilhetes conversíveis. Este fato poderia, paradoxalmente, beneficiar a economia cafeeira porque agora, com a crise, o fluxo de ouro se invertera e a tendência era de desvalorização do mil-réis.

Tivesse a guerra se iniciado no primeiro semestre de 1914, o funding loan não teria sido possível na forma que ocorreu e a economia brasileira teria que buscar alternativas à falta de divisas. $\mathrm{O}$ conflito mundial trouxe muitas alterações na economia internacional e o café, que já era elemento fundamental para a inserção do Brasil na economia internacional, passou para outro nível de importância, mas agora em cenário radicalmente diferente, com consequências relevantes para a economia brasileira.

As alterações na economia internacional começaram antes de julho de 1914 porque as regras nas principais praças financeiras europeias passaram a incluir o entesouramento para fazer frente à demanda por investimentos na indústria bélica e para o contingenciamento que permitisse aos países europeus enfrentar as Guerras Balcânicas de 1912 e 1913. Estas guerras foram ampliadas e continuaram na forma da Primeira Guerra Mundial que teve de um lado os países da Tríplice Entente - Império 
Britânico, França, Império Russo e Estados Unidos - e do outro os países que constituíram a Tríplice Aliança - Bulgária, Império Alemão, Império Austro-Húngaro e Império Otomano - principais protagonistas de batalhas que exigiram ainda mais restrições orçamentárias com consequências diretas para o comércio exterior e para o fluxo internacional de capitais.

Londres ainda representava a consubstanciação do mercado financeiro internacional e alterações naquela praça tinham impacto mundial, em especial para países como o Brasil que necessitavam da poupança externa para financiar o balanço de pagamentos. As mudanças nas prioridades financeiras do Reino Unido paralisaram as negociações para a concessão de crédito internacional, deixando a economia brasileira inesperadamente sem condições de prever a entrada no país de recursos extraordinários em moeda conversível. O empréstimo que estava em negociação quando a guerra irrompeu era o da consolidação da dívida externa brasileira, o segundo funding loan que o país realizava e que internamente se transformou em sinônimo de solução para o estrangulamento externo que colocara a economia brasileira em posição de default, com negócios internos estancados e financiamento público inviabilizado.

O contrato do funding loan já estava em formatação muito antes dos eventos em Sarajevo porque a crise balcânica expusera com força as falhas de mercado da economia nacional, essencialmente no que se refere à dependência de ouro para financiar o orçamento e para cobrir o balanço de pagamentos, ouro que teria sido liberado pelos banqueiros europeus capitaneados pela casa bancária dos Rothschilds no primeiro semestre de 1914, não fosse a eclosão da guerra. A falta de fontes regulares de moeda conversível - a Caixa de Conversão interrompeu as emissões de moeda conversível pouco antes do início da guerra - e o envolvimento das potências europeias no conflito mundial funcionaram como aval para a política econômica brasileira voltar a se servir do expediente de imprimir moeda sem lastro como resposta à supressão de meio circulante que estagnava o comércio. A volta da emissão com curso forçado com Calógeras na Fazenda foi o ponto final para a experiência brasileira com o padrão-ouro na margem e com medidas de cunho ortodoxo que ainda davam mote para discussões entre papelistas e metalistas. Foi durante a guerra que os seguidores de Murtinho e defensores do bulionismo perderam o espaço que ainda ocupavam nas discussões sobre os rumos da política econômica brasileira e que medidas inusitadas do Ministério da 
Fazenda alteraram a política econômica com o intuito de permitir condições mínimas para os negócios internos e externos.

A grave carência de recursos em moeda conversível durante a guerra persistiu mesmo após a assinatura do contrato do funding porque os recursos que foram liberados tiveram destinação específica - o pagamento de compromissos com bancos e empresas estrangeiras - e deixaram exígua margem de manobra para o governo federal. Apesar da falta de divisas, os orçamentos públicos continuaram a ser executados com déficit elevado durante a guerra o que agravou os problemas econômicos porque o Brasil não podia mais contar nem mesmo com as exportações regulares que passaram a ser obstadas como forma de prevenir contrabando que gerasse transferência de recursos para o Império Alemão e seus aliados. Estes fatores levaram à redução de termos de troca o que limitou em muito a arrecadação das rendas aduaneiras, principal fonte de financiamento do orçamento da União. A escassez de ouro entre 1914 e 1918 abriu espaço para que o Banco do Brasil ampliasse a sua atuação no setor externo da economia brasileira e se transformasse no agente financeiro responsável pelo câmbio e pelo comércio exterior do país, sempre com o objetivo de obter cambiais, mesmo que por meio de medidas heterodoxas em transações que envolveram agentes do mercado financeiro internacional da Europa e dos Estados Unidos.

A atuação do Banco do Brasil durante a guerra ocorreu em parceria ou em paralelo às atividades das casas bancárias britânicas Rothschild e Schröder, banqueiros que se notabilizaram no Brasil neste período por terem estruturado os contratos relacionados à dívida externa e à concessão de crédito ao país e ainda por terem organizado as negociações do café de São Paulo no mercado internacional. Os banqueiros do Rothschild tiveram mais destaque por terem viabilizado o funding loan $\mathrm{e}$ também porque foram os negociadores oficiais do Brasil junto ao governo britânico nas diversas tentativas da equipe econômica de Wenceslau Braz em tentar obter créditos e recursos extraordinários em Londres durante as restrições financeiras provocadas pela guerra. Foram eles os porta-vozes do governo brasileiro nas solicitações de liberação de exportações de café para países neutros ou participantes da Tríplice Entente, solicitações que quando aprovadas pelo War Trade Department do Reino Unido significavam exceções às proibições de comércio exterior durante a guerra e distorções no mercado internacional do café porque o fato gerador das exportações do produto passou a depender com mais peso das necessidades brasileiras de ouro e menos da demanda 
efetiva do mercado consumidor final. A prática de especulação com os estoques na Europa que vinha desde o Convênio de Taubaté foi inviabilizada durante a guerra justamente porque as liberações das vendas eram de caráter isolado, feitas caso a caso, e entendidas como exceções. Desta forma, as negociações do comércio internacional praticado pelo Brasil durante a fase de país neutro passaram a ter forte ingerência da burocracia britânica.

As dificuldades na economia internacional que o Brasil passou a enfrentar na guerra, apesar de inéditas e de grande impacto macroeconômico, não foram suficientes para alterar a falta de visão do governo e da elite que controlava os negócios no país para que fosse aproveitada a oportunidade com a alteração radical no cenário mundial e enfrentado o maior problema econômico do país que era a dependência da economia dos recursos em moeda conversível. O clima de mudanças que a guerra propiciou não se traduziu em modificações no status quo no Brasil, mas sim na implantação de processos criativos de defesa do modelo primário-exportador que acabaram fornecendo sobrevida a uma estrutura anacrônica e com poder suficiente para manter o país preso ao capitalismo tradicional. As dificuldades na condução da economia brasileira já vinham desde o final de 1912, mas a Primeira Guerra Mundial encetou efeitos colaterais originados na posição de neutralidade que o Brasil assumiu assim que começaram os conflitos e que foi mantida até meados de 1917. Ser um país neutro em um mundo em guerra total significou para Brasil tecer parcerias e acordos de cooperação com os países da Tríplice Entente, mas ao mesmo tempo equilibrar-se nas relações internacionais para não demonstrar atitudes hostis para com o Império Alemão que fora o maior comprador de café brasileiro até julho de 1914. O governo brasileiro acreditava que o fim da guerra levaria o mercado internacional ao ponto de onde havia parado quando o Reino Unido declarou guerra à Alemanha e a radicalização nas relações internacionais do país não seria benéfica para os negócios. Ser um país neutro significou para o Brasil ver negada a quase totalidade das solicitações para a prática do comércio exterior e ter que operar de maneira criativa com o Banco do Brasil para enfrentar o fechamento do sistema de logística internacional para produtos supérfluos e de fácil contrabando como foi classificado o café. Utilizar navios brasileiros no transporte internacional era uma prática inviável não apenas pela carência de embarcações que suportassem viagens longas, mas também porque os submarinos alemães passaram a torpedear até mesmo os barcos que tinham portos neutros como destino final. 
A importância do setor externo para a economia brasileira foi colocada à prova durante as hostilidades que alteraram de maneira radical a forma pela qual se processaram o comércio internacional e os investimentos estrangeiros para o Brasil. Como o setor externo era o mais importante para a economia brasileira daquele período, entender as modificações que vigoraram entre 1914 e 1918 na economia internacional auxilia na compreensão da dimensão dos impactos da guerra na economia brasileira.

A Primeira Guerra Mundial alterou profundamente o comércio exterior do Brasil. Exportações regulares de café, mas também de borracha, açúcar, fumo e demais produtos que perfaziam a base da pauta de exportações do país até o início dos conflitos não mais puderam ocorrer na forma que se verificavam. Houve a necessidade de encontrar substitutos para as empresas alemãs que comercializavam larga escala do café brasileiro. $\mathrm{Na}$ ausência de alternativas junto ao setor privado internacional que pudesse fazer este papel, coube ao governo brasileiro protagonizar negociações internacionais que permitiram colocar o café nas praças internacionais e assim obter divisas para financiar as importações. Estas negociações entraram no lugar das negociações regulares do mercado, enviesaram os valores contabilizados e serviram como moeda de troca para o Reino Unido pressionar o Brasil a entrar na guerra no lado da Entente.

Não foi fácil para o governo brasileiro finalmente declarar guerra aos países da Tríplice Aliança porque havia muito receio sobre como a Alemanha entenderia este ato no pós-guerra. A força da Statutory List (SL) ajudou nesta tomada de decisão porque Londres passou a acenar com maior liberdade para o Brasil colocar produtos no mercado internacional e assim conseguir as divisas que tanto necessitava. O sucesso da SL em alcançar o objetivo de limitar o acesso de recursos internacionais pela Alemanha se traduziu em muita insatisfação no Brasil porque todo o comércio exterior do país teve que se sujeitar às novas regras que tiraram do país a possiblidade em continuar com os planos de valorização do café. Mercados de países neutros importantes, como a Holanda e os países escandinavos, foram excluídos como importadores do produto brasileiro.

A guerra abriu a possiblidade de o Brasil exportar produtos não tradicionais, como manganês e carne enlatada. O manganês foi motivo de ações de Londres que visaram assegurar a permanência do capital britânico em minas localizadas na região de São João Del Rey (MG). A industrialização da carne foi motivo de elogios no mercado internacional porque o Brasil estaria se adaptando ao novo cenário do comércio exterior. 
A borracha foi alvo de disputa internacional porque o produto voltou a ser investimento importante para o Reino Unido e também para os Estados Unidos.

Foi com relação às importações que os efeitos da guerra foram mais duros. Fornecedores usuais foram excluídos do mercado, faltaram divisas para a aquisição dos produtos e navios para o transporte. As barreiras aos produtos importados atingiram sem distinção bens de consumo e bens de capital. A diminuição na oferta de bens de consumo importados pode ter auxiliado a industrialização brasileira, mas as adversidades que a guerra trouxe foram impeditivas para investimentos em máquinas e equipamentos que poderiam ter sedimentado o setor industrial no desenvolvimento econômico brasileiro antes de 1930.

A falta de divisas e as negociações extraordinárias para as exportações encampadas pelo governo provocaram oscilação excessiva na taxa cambial. Este elemento somado aos problemas de fornecimento de artigos de consumo provocaram carestia e pressão para o governo de Wenceslau Braz encontrar saídas para a crise. O cenário internacional mudou para o Brasil após dois eventos: o rompimento com o Império Alemão e a consolidação dos Estados Unidos como líder da economia internacional.

A passagem do controle da economia internacional para os Estados Unidos ocorreu quando a economia britânica não suportou mais arcar com os pesados custos que a guerra exigia. Os ataques alemães se intensificaram, bloqueando importantes rotas de comércio para os negócios do Reino Unido. Do outro lado do Atlântico estavam os Estados Unidos prontos para financiar as contas públicas britânicas. A economia norteamericana passou a receber quantidade de ouro muito superior às suas necessidades. Este ouro tinha como origem as importações que países beligerantes e neutros começaram a fazer de produtos dos Estados Unidos. A guerra cessou ou dificultou a produção europeia de muitos artigos essenciais, como químicos e aço. As empresas norte-americanas conseguiram investir na ampliação de suas produções e atender mercados não planejados em quantidades muito acima do que vinham realizando até aquele momento. $\mathrm{O}$ excesso de ouro nos Estados Unidos permitiu ao país financiar o final da guerra com vitória dos países da Entente. Este ouro norte-americano chegou ao Brasil na forma de importação de produtos primários e como crédito para as finanças públicas e para os negócios privados no Brasil. Havia sido feita a passagem do controle 
da economia mundial do Reino Unido para os Estados Unidos com impactos no Brasil que começaram antes do final da Primeira Guerra Mundial. 


\section{ARQUIVOS E BIBLIOTECAS}

Arquivo Geral do Estado de São Paulo (AGESP), São Paulo, SP

Jornais comerciais

Biblioteca da Associação Comercial de São Paulo, São Paulo, SP

Publicações oficiais

Biblioteca Nacional, Rio de Janeiro, RJ

Periódicos diversos e publicações oficiais

Biblioteca Roberto Simonsen, Instituto de Filosofia e Ciências Humanas da Universidade de Campinas (IFCH-UNICAMP)

Boletins informativos

The British Library, Londres, Reino Unido

Bibliografia secundária

The National Archives (TNA), Kew Gardens, Londres, Reino Unido

Foreign Office Papers (FO) e Treasury Papers (T). Pastas variadas.

The Rothschild Archive (TRA), New Court, Londres, Reino Unido

Boletins informativos

\section{Publicações oficias}

Balanço da receita e despesa da República no exercício de 1913. Rio de Janeiro: Imprensa Oficial, 1924.

Balanço da receita e despesa da República no exercício de 1914. Rio de Janeiro: Imprensa Oficial, 1928.

Coleção Wileman. Brazilian Review, 1898-1940.

Diversos volumes.

http://memoria.org.br/wbr1.php

Defesa da Borracha e Brasileira e a Repressão do Contrabando no Amazonas. Imprensa Oficial, Rio de Janeiro: 1924

Estatística das Estradas de Ferro do Brasil relativa ao ano de 1920. Inspetoria Federal das Estradas. Rio de Janeiro: 1924.

Estatística das Finanças do Brasil: receitas, despesas, e dívidas públicas da União dos Estados e dos Municípios. Rio de Janeiro: Tipografia da Estatística, 1926.

Exposição e proposta de orçamento da receita e despesa do exercício de 1920. Rio de Janeiro: Imprensa Oficial, 1919. 
IBGE - Anuário Estatístico do Brasil, Ano V, 1939-40, Apêndice - Séries Retrospectivas, p. 1333. Tabela II - Curso do câmbio na Praça do Rio de Janeiro, $1822 / 1939$.

IBGE - Instituto Brasileiro de Geografia e Estatística, Repertório Estatístico do Brasil Quadros Retrospectivos $n^{\circ}$ 1, Rio de Janeiro: Serviço Gráfico do Instituto Brasileiro de Geografia e Estatística, 1941.

Lei Orçamentária para o exercício de 1913. Rio de Janeiro: Imprensa Oficial, 1913.

Lei Orçamentária para o exercício de 1914. Rio de Janeiro: Imprensa Oficial, 1914.

Lei Orçamentária para o exercício de 1915. Rio de Janeiro: Imprensa Oficial, 1915.

Lei Orçamentária para o exercício de 1916. Rio de Janeiro: Imprensa Oficial, 1916.

Lei Orçamentária para o exercício de 1917. Rio de Janeiro: Imprensa Oficial, 1917.

Lei Orçamentária para o exercício de 1918. Rio de Janeiro: Imprensa Oficial, 1918.

Lei Orçamentária para o exercício de 1919. Rio de Janeiro: Imprensa Oficial, 1919.

Ministério da Fazenda, Balanço da receita e despesa da República no exercício de 1913, Rio de Janeiro: Imprensa Oficial, 1924.

Ministério da Fazenda, Balanço da receita e despesa da República no exercício de 1914, Rio de Janeiro: Imprensa Oficial, 1928.

Ministério da Fazenda, Orçamento da receita e despesa do exercício de 1920, Rio de Janeiro: Imprensa Oficial, 1919.

Mensagem apresentada ao Congresso Nacional. Rio de Janeiro 1913. Biblioteca da Presidência da República.

http://www.biblioteca.presidencia.gov.br/ex-presidentes/hermes-fonseca/mensagenspresidenciais/mensagem-ao-congresso-nacional-na-abertura-da-segunda-sessao-daoitava-legislatura-1913/view

Mensagem apresentada ao Congresso Nacional. Rio de Janeiro, 1914. Biblioteca da Presidência da República.

http://www.biblioteca.presidencia.gov.br/ex-presidentes/hermes-fonseca/mensagenspresidenciais/mensagem-ao-congresso-nacional-na-abertura-da-terceira-sessao-daoitava-legislatura-1914/view

Mensagem apresentada ao Congresso Nacional. Rio de Janeiro, 1915. Biblioteca da Presidência da República.

http://www.biblioteca.presidencia.gov.br/ex-presidentes/wenceslau-braz/mensagenspresidenciais/mensagem-ao-congresso-nacional-na-abertura-da-primeira-sessao-danona-legislatura-1915/view 
Ministério da Agricultura, Indústria e Comércio. Diretoria Geral de Estatística. Estatística das Finanças do Brasil - Receitas, despesas e dívidas públicas da União, Estados e Municípios. Rio de Janeiro, 1926.

Ministério da Agricultura, Indústria e Comércio. Resumo de várias Estatísticas Econômico-Financeiras. Diretoria Geral de Estatística. Rio de Janeiro, 1924.

Ministério da Fazenda - Galeria de ministros: João Pandiá Calógeras. http://www.fazenda.gov.br/institucional/galeria-dos-ministros/republica/joao-pandiacallogeras-1.

Relatório do Ministério dos Negócios da Fazenda - 1913. http://brazil.crl.edu/bsd/bsd/u1763/contents.html

Relatório do Ministério dos Negócios da Fazenda - 1914. Center for Research Libraries. Global Resources Network. http://brazil.crl.edu/bsd/bsd/u1765/contents.html

Relatório do Ministério dos Negócios da Fazenda - 1915. http://brazil.crl.edu/bsd/bsd/u1766/contents.html

Relatório do Ministério dos Negócios da Fazenda - 1917. Center for Research Libraries. Global Resources Network. http://brazil.crl.edu/bsd/bsd/u1768/contents.html Relatório do Ministério dos Negócios da Fazenda - 1918. http://brazil.crl.edu/bsd/bsd/u1770/contents.html

Relatório do Ministério dos Negócios da Fazenda - 1919. http://brazil.crl.edu/bsd/bsd/u1771/contents.html

Senado Federal - Site: "Assassinato do senador gaúcho Pinheiro Machado completa 100 anos nesta ter-feira".

http://www12.senado.gov.br/radio/1/noticia/assassinato-do-senador-gaucho-pinheiromachado-completa-100-anos-nesta-terca-feira>

\section{Periódicos, compêndios e retrospectos}

O anno commercial e financeiro de 1917 - Ramalho Ortigão - Associação Comercial do Rio de Janeiro. Rio de Janeiro: 1918

A Época (1917)

O Estado de S. Paulo (1906-1921)

O Imparcial (1913)

Retrospecto Comercial 1913, Jornal do Commercio. Rio de Janeiro: Typ. do Jornal do Commercio, 1914. 
Retrospecto Comercial 1914, Jornal do Commercio. Rio de Janeiro: Typ. do Jornal do Commercio, 1915.

Retrospecto Comercial 1915, Jornal do Commercio. Rio de Janeiro: Typ. do Jornal do Commercio, 1916.

Retrospecto Comercial 1916, Jornal do Commercio. Rio de Janeiro: Typ. do Jornal do Commercio, 1917.

Retrospecto Comercial 1917, Jornal do Commercio. Rio de Janeiro: Typ. do Jornal do Commercio, 1918.

Retrospecto Comercial 1918 do Jornal do Comércio. Rio de Janeiro: Typ. do "Jornal do Commercio", 1919.

Retrospecto Comercial 1919 do Jornal do Comércio. Rio de Janeiro: Typ. do "Jornal do Commercio", 1920.

Suplemento à tarifa das alfândegas. Rio de Janeiro: Tipografia da Alfândega do Rio de Janeiro, 1918.

\section{$\underline{\text { Sites oficiais }}$}

Assemblée Nationale. Base de données des députés français depouis 1789. http://www.assemblee-nationale.fr/sycomore/fiche.asp?num_dept=7958

Coleção Wileman. Brazilian Review, 1898-1940. Diversos volumes. http://memoria.org.br/wbr1.php

Decreto 10.197 de 29 de abril de 1913. Câmara do Deputados - Legislação Informatizada - Publicação Original. http://www2.camara.leg.br/legin/fed/decret/19101919/decreto-10197-29-abril-1913-523394-publicacaooriginal-1-pe.html.

Decreto $\mathrm{n}^{\circ}$ 2.863, de 24 de agosto de 1914. Câmara dos Deputados - Legislação Informatizada - Publicação Original - http://www2.camara.leg.br/legin/fed/decret/19101919/decreto-2863-24-agosto-1914-575504-publicacaooriginal-98707-pl.html

Decreto $\mathrm{n}^{\mathrm{o}} 2.933$ (Lei Calógeras), de 6 janeiro de 1915 que regula a propriedade das minas.

Câmara do Deputados - Legislação Informatizada- Publicação Original.

http://www2.camara.leg.br/legin/fed/decret/1910-1919/decreto-2933-6-janeiro-1915-

574337-publicaooriginal-97500-pl.html

Decreto ${ }^{\circ} 11.511$, de 04 de março de 1915

http://www.lexml.gov.br/urn/urn:lex:br:federal:decreto:1915-03-04;11511

Governo de Santa Catarina. Secretaria Executiva da Casa Militar.

http://www.casamilitar.sc.gov.br/governadores.asp

Governadores do Estado de Santa Catarina 
www.casamilitar.sc.gov.br/governadores.asp

Portal da Prefeitura de Santos. Histórias e lendas de Santos:

Theodor Wille

www.novomilenio.inf.br/santos/h0090d.htm

Empresa Nacional de Navegação Hoepcke:

http://www.novomilenio.inf.br/santos/h0430d.htm.

\section{$\underline{\text { Sites diversos }}$}

ßBanco do Brasil. 'História do Banco do Brasil'. Diretoria de Marketing e Comunicação do Banco do Brasil. Belo Horizonte: Del Rey, Fazenda Comunicação \& Marketing, $\underline{2010 .}$

Banco do Brasil. 'O papel moeda', História da Moeda. http://www.bb.com.br/portalbb/page3,8703,8725,1,0,1,6.bb?codigoNoticia=5558\&codi goMenu $=4686 \&$ codigoRet $=4705 \&$ bread $=2 \_3$

Banco do BrasilC - World War One. http://www.ww1propaganda.com; http://www.bbc.com/ww1

Chronologie der Erste Weltkrieg.

htp://.welt.de/themen/erster-weltkrieg/

Facas Riograndenses. Bromberg \& Cia. http://facasriograndenses.blogspot.com.br/2013/03/blog-post.html\#!/2013/03/blogpost.html

FGV-CPDOC. Biografia - João Pandiá Calógeras. http://cpdoc.fgv.br/producao/dossies/AEraVargas1/biografias/pandia_calogeras;>

Freie Universität Berlin - Lateinamerika-Institut (LAI).

Protestantische Deutsche in Brasilien. Eine Diskursgeschichte 1864 - 1945. www.lai.fu-

berlin.de/forschung/forschungprojekte/aktuelle_projekte/deutsche_einwanderung_nach_ brasilien/index.html

Great War London. London and Londoners in The First World War. 'The King's Speech, 1917'.

https://greatwarlondon.wordpress.com/2012/05/08/the-kings-speech-1917/

Histórias e lendas de Santos. Embarcações Naufragadas.

http://www.novomilenio.inf.br/santos/h0430d.htm

Israel Ministry of Foreign Affairs. The Balfour Declaration. 
http://www.mfa.gov.il/mfa/foreignpolicy/peace/guide/pages/the\%20balfour\%20declarat ion.aspx.

Mises Institute. Austrian Economics, Freedom, and Peace. 'The Monetary Breakdown of the West', Murray N. Rothbard. https://mises.org/library/monetary-breakdown-west.

The Library of Congress - America's Library.

http://www.americaslibrary.gov

The History Learning Site. Lord Kitchner.

http://www.historylearningsite.co.uk/LordKitchener.htm

Theodor Wille Intertrade. About us. More than 171 years ago, Theodor Wille had a great idea.

http://www.twipv.com/about-us

\section{Referências bibliográficas}

ALBERT, Bill. South America and the First World War: the impact of the war on Brazil, Argentina, Peru and Chile. Nova York: Cambridge University Press, 1988.

ALDCROFT, Derek, H. The European economy 1914-2000. Londres: Taylor \& Francis e-library. 2002.

ABREU, Marcelo de Paiva. John Maynard Keynes e as relações econômicas anglobrasileiras durante a II Guerra Mundial. Revista Brasileira de Economia, Rio de Janeiro, 36 (1): 35-50, jan./mar. 1982.

Brasil, 1824-1957: bom ou mau pagador?. Texto para discussão $\mathrm{n}^{\mathrm{o}} 403$, Departamento de Economia PUC-RIO, agosto 1999, p. 11-7.

Os funding loans brasileiros - 1898-1931. Pesquisa e Planejamento Econômico. PPE. V. 32. No 3. Dez. 2002.

(org.). A Ordem do Progresso: Cem Anos de Política Econômica Republicana 1889-1989. Rio de Janeiro: Campus, 1990.

BAER, Werner. A industrialização e o desenvolvimento econômico do Brasil. Rio de Janeiro: Fundação Getúlio Vargas, 1979.

BENTIVOGLIO, Julio. Cultura política e historiografia alemã no século XIX: a Escola Histórica Prussiana e a Historische Zeitschrift. Revista de Teoria da História Ano 1, Número 3, junho/2010. Universidade Federal de Goiás.

BUENO, Clodoaldo. Política externa da Primeira República: os anos de apogeu (1902 a 1918). São Paulo: Paz e Terra, 2003.

BUESCU, Mircea. O reerguimento econômico (1903-1913). Brasília: Revista de Informação Legislativa, ano 25, nr. 99, jul./set. 1988. 
CALÓGERAS, Pandiá J. Formação histórica do Brasil. São Paulo: Companhia Editora Nacional, 1972.

Pandiá J. Problemas de Administração - Relatório confidencial apresentado em 1918 ao Conselheiro Rodrigues Alves sobre a situação orçamentária $e$ administrativa do Brasil. São Paulo: Companhia Editora Nacional, 1918.

As minas do Brasil e sua legislação. Rio de Janeiro: Imprensa Oficial, 1904-5.

CASTRO, Viveiros de. A História Tributária do Brasil. Instituto Histórico e Geográfico Brasileiro. Rio de Janeiro: 1915.

CARONE, Edgard. O pensamento industrial no Brasil (1880-1945). São Paulo: DIFEL, 1977.

CARONE, Edgard. A evolução industrial de São Paulo (1889-1930). São Paulo: Editora SENAC São Paulo, 2001.

CAVALCANTI, Pedro. A presidência Wenceslau Braz: 1914-1918. Brasília: Editora Universidade de Brasília, 1983.

CAVALCANTI, Jacob. Histórico da Dívida Externa Federal. Imprensa Oficial, Rio de Janeiro: 1923.

DEAN, Warren. A industrialização de São Paulo, 1880-1945. 3a ed., São Paulo: Difel, 1971.

FRANK, Zephyr e MUSACaixa de ConversãoHIO, Aldo. The international natural rubber Market, 1870 -1930. Stanford University, Ibmec São Paulo. http://eh.net/encyclopedia/the-international-natural-rubber-market-1870-1930/

FRITSCH, Winston. Aspectos da política econômica no Brasil, 1906-1914. In: Economia brasileira: uma visão histórica / coordenador: Paulo Neuhaus. Rio de Janeiro: Campus, 1980.

GOLDSTEIN, Erik. 'Wars \& Peace Treaties 1816-1991'. London: Routledge, 1992.

GUYOT, Yves. Les causes et les conséquences de la guerre. Paris: Librairie Félix Alcan, 1915.

HADBA, Fernando Antônio. Caixas de Conversão. Rio de Janeiro: Revista de Economia Política, vol. 14, n. 1 (53), janeiro-março/1994.

HALL, Richard C. Hall. The Balkan Wars, 1912-1913 - Prelude to the First World War. Londres: Taylor \& Francis e-Library, 2002.

HAMILTON, Ricard F.; HERWIG, Holger H. The Origins of World War I, Cambridge: Cambridge University Press, 2003. 
LUZ, Nícia Vilela. A luta pela industrialização do Brasil. São Paulo: Alfa-Ômega, 1975.

MACMILLAN, Margaret. The War That Ended Peace. Londres: CPI Group, 2013.

MESQUITA, Júlio. A guerra (1914-1918). O Primeiro ano. São Paulo: O Estado de S. Paulo: Editora Terceiro Nome, 2002.

MONTE, Francisca Silvania de Sousa. O uso e controle das águas no processo de modernização do Estado do Ceará: o caso da Barragem do Castanhão. Tese de doutorado. UFRJ, 2005.

NEUHAUS, Paulo. História monetária do Brasil, 1900 - 1945. Rio de Janeiro: IBMEC, 1975.

OLIVEIRA, Maria Teresa Ribeiro e SILVA, Maria Luiza Falcão. 'O Brasil no padrãoouro: a Caixa de Conversão de 1906-1914'. In: História Econômica \& História de Empresas IV, I. São Paulo: Editora UCITEC, 2001.

PELÁEZ, Carlos Manuel. História econômica do Brasil: em elo entre a teoria e a realidade econômica. São Paulo: Atlas, 1979.

PICCAROLO, A.; FINOCCCHI, L. (orgs). O desenvolvimento industrial de s. Paulo através da Primeira Exposição Industrial Municipal. São Paulo: Pocai \& Companhia, 1918.

PRADO JR, Caio. História Econômica do Brasil. São Paulo: Editora Brasiliense, 1976.

ROCKOFF, Hugh. Until it's over, over there: The U. S. economy in World War I. National Bureau of Economic Research. Cambridge: Working Paper 10580, 2004.

SAES, Flávio Azevedo Marques de. Crédito e bancos no desenvolvimento da economia paulista. 1850-1930. São Paulo: IPE/USP, 1986.

SCHURMAN, Jacob Gould. The Balkan Wars, 1912-1913. Terceira edição, 1916

http://www.munseys.com/disktwo/balkan.pdf

SIMONSEN, Roberto C. Evolução Industrial do Brasil e outros estudos. São Paulo: Editora Nacional e Editora da USP, 1973.

TEMIN, Peter et al. The world economy between the World Wars. Nova York: Oxford University Press, 2008.

VERSIANI, F. R. e M. T. A industrialização brasileira antes de 1930: uma contribuição. In: VERSIANI, F. R. e BARROS, J. R. M. (orgs). Formação econômica do Brasil. São Paulo: Editora Saraiva, 1977. 
VILLELA, André. Tarifas de importação e câmbio na gênese da indústria brasileira, 1901-1928. Rio de Janeiro: História econômica \& história de empresas III. 2 (2000), 27 46.

WERNECK, Nelson. História da burguesia brasileira. Rio de Janeiro: Editora Civilização

Brasileira S/A, 1967.

WILEMAN, J. P. Brazil Exchange: The study of an inconvertible currency. Buenos Aires: Galli Bros, 1896. 